\title{
BRUNO LUÍS AMORIM PINTO
}

\section{O REGIME JURÍDICO DOS CONTRATOS DE COLABORAÇÃO ENTRE O ESTADO BRASILEIRO E O TERCEIRO SETOR}

\author{
Dissertação de Mestrado \\ Orientadora: Professora Titular Doutora Maria Sylvia Zanella Di Pietro
}

UNIVERSIDADE DE SÃO PAULO

FACULDADE DE DIREITO

São Paulo/SP

2015 


\title{
BRUNO LUÍS AMORIM PINTO
}

\section{O REGIME JURÍDICO DOS CONTRATOS DE COLABORAÇÃO ENTRE O ESTADO BRASILEIRO E O TERCEIRO SETOR}

\begin{abstract}
Dissertação apresentada à Banca Examinadora do Programa de Pós-graduação em Direito, da Faculdade de Direito da Universidade de São Paulo, como exigência parcial para obtenção do título de Mestre em Direito, na área de concentração Direito do Estado, sob a orientação da Professora Titular Doutora Maria Sylvia Zanella Di Pietro.
\end{abstract}

\section{UNIVERSIDADE DE SÃO PAULO \\ FACULDADE DE DIREITO}

\section{São Paulo/SP}


Autorizo a reprodução e divulgação parcial deste trabalho, por qualquer meio convencional ou eletrônico, para fins de estudo e pesquisa, desde que citada a fonte.

PINTO, Bruno Luís Amorim.

O Regime Jurídico dos Contratos de Colaboração entre o Estado Brasileiro e o Terceiro Setor / Bruno Luís Amorim Pinto, São Paulo: USP / Faculdade de Direito, 2015.

$157 \mathrm{f}$.

Orientadora: Professora Titular Doutora Maria Sylvia Zanella Di Pietro. Dissertação (Mestrado), Faculdade de Direito, Universidade de São Paulo, São Paulo, 2015.

1. Contrato de colaboração 2. Estado Brasileiro 3. Terceiro setor 4. Regime Jurídico I. Maria Sylvia Zanella Di Pietro. II. Universidade de São Paulo, Faculdade de Direito. III. Título. 


\title{
BRUNO LUÍS AMORIM PINTO
}

\section{O REGIME JURÍDICO DOS CONTRATOS DE COLABORAÇÃO ENTRE O ESTADO BRASILEIRO E O TERCEIRO SETOR}

\begin{abstract}
Dissertação apresentada à Banca Examinadora do Programa de Pós-graduação em Direito, da Faculdade de Direito da Universidade de São Paulo, como exigência parcial para obtenção do título de Mestre em Direito, na área de concentração Direito do Estado, sob a orientação da Professora Titular Doutora Maria Sylvia Zanella Di Pietro.
\end{abstract}

Aprovado em:

Banca Examinadora:

Professora Titular Doutora Maria Sylvia Zanella Di Pietro (Orientadora) Instituição: Universidade de São Paulo - USP

Julgamento:

Assinatura:

Professor Titular Doutor Fernando Dias Menezes de Almeida Instituição: Universidade de São Paulo - USP

Julgamento:

Assinatura:

Professora Doutora Dinorá Adelaide Musetti Grotti Instituição: Pontifícia Universidade Católica de São Paulo - PUC/SP Julgamento:

Assinatura:

Professor Doutor Rodrigo Pagani de Souza

Instituição: Universidade de São Paulo - USP

Julgamento:

Assinatura:

Professor Doutor Marcos Augusto Perez

Instituição: Universidade de São Paulo - USP

Julgamento:

Assinatura:

Professor Doutor Thiago Marrara

Instituição: Nova Faculdade de Direito da Universidade de São Paulo - USP Julgamento:

Assinatura: 
A Marina Morena, com muita saudade. 


\section{AGRADECIMENTOS}

À minha orientadora, Doutora Maria Sylvia Zanella Di Pietro, por me receber no Programa de Pós-graduação da Faculdade de Direito da Universidade de São Paulo, permitindo-me um aprendizado único e orientando-me com imensa sabedoria, paciência e carinho.

A todos os demais Professores da Faculdade de Direito da Universidade de São Paulo, mentes brilhantes e verdadeiras fontes de inspiração.

A Paulo Modesto, por guiar os meus primeiros passos no estudo do Direito Administrativo.

Aos meus pais e irmãos, por terem sempre me apoiado e acreditado no meu potencial, pessoas fundamentais em minha vida.

Aos meus demais familiares, que carrego no peito por todos os lugares que vou.

Aos meus amigos, com os quais compartilho grandes momentos. 
"O homem não é nada além daquilo que a educação faz dele”.

(Immanuel Kant) 


\section{RESUMO}

PINTO, Bruno Luís Amorim. O Regime Jurídico dos Contratos de Colaboração entre o Estado Brasileiro e o Terceiro Setor. 2015. 157f. Dissertação (Mestrado) - Faculdade de Direito, Universidade de São Paulo, São Paulo, 2015.

Trata-se de dissertação de mestrado sobre o regime jurídico dos assim chamados contratos de colaboração, instrumentos negociais de caráter continuado celebrados entre o Estado Brasileiro e o terceiro setor, organizações da sociedade civil sem fins lucrativos de objetivos sociais. Situa-se no contexto do crescente processo de emparceiramento dos setores público e privado brasileiros vivenciado nas últimas duas décadas, resultado da redemocratização do país comandada pela Constituição Federal de 1988, com a revitalização da cidadania ativa e reintrodução do homem no centro do jogo político, econômico e social. Tem como pano de fundo a mudança paradigmática da Administração Pública Brasileira operada pela Reforma da década de 1990, que substituiu o perfil essencialmente burocrático dos órgãos e entidades administrativas pelo modelo gerencial de gestão pública, caracterizado pela flexibilização de procedimentos, recurso à consensualidade, estímulo à participação cidadã, foco na eficiência das prestações administrativas e incorporação do controle de resultados. Examinando a natureza jurídica desses vínculos formais de parceria nos serviços sociais, das partes envolvidas e do seu objeto, este trabalho constrói um estatuto jurídico mínimo/comum de toda e qualquer relação colaborativa social entabulada entre o Estado Brasileiro e a iniciativa privada sem fins lucrativos, rompendo com a dicotomia estanque dos regimes de Direito Público e Direito Privado. É nessa perspectiva que se analisam 04 (quatro) subregimes: de seleção de entidades privadas de colaboração; de prestação colaborada de serviços sociais; de contratação de terceiros pelas entidades privadas de colaboração; e de controle dos contratos de colaboração.

Palavras-chave: Contrato de colaboração. Estado Brasileiro. Terceiro Setor. Serviços sociais. Regime jurídico. 


\begin{abstract}
PINTO, Bruno Luís Amorim. The Legal Framework of the Collaboration Contracts Concluded between the Brazilian State and the Third Sector. 2015. 157p. Thesis (Master) - Faculdade de Direito, Universidade de São Paulo, São Paulo, 2015.

This is a Master's Thesis on the legal framework of the so-called collaboration contracts, continuous trading instruments concluded between the Brazilian State and the third sector, non-profit organizations with social objectives. It is located in the context of the growing partnership process betwixt the Brazilian public and private sectors experienced in the last two decades, a consequence of the re-democratization of the country coordinated by the Federal Constitution of 1988, with the revitalization of active citizenship and reintroduction of the man at the center of political, economic and social game. It's background is the paradigm shift of the Brazilian Public Administration operated by the Reform of the 1990s, which replaced the essentially bureaucratic profile of organs and administrative bodies by the managerial model of public management, characterized by the easing of procedures, use of consensuality, encouraging of citizen participation, focus on the efficiency of administrative services and incorporation of the control over results. Examining the legal nature of these partnerships in social services, of the parties involved and of their object, this study develops a minimum/common legal framework of any social collaborative relationship engaged by the Brazilian State with the non-profit private initiative, breaking with the tight dichotomy of Public Law and Private Law regimes. In this perspective, it is analyzed four sub-schemes: selection of collaborative private entities; collaboratively provision of social services; contracting of third parties by collaborative entities; and control of collaboration contracts.
\end{abstract}

Keywords: Collaboration contract. Brazilian State. Third Sector. Social services. Legal framework. 


\section{SUMÁRIO}

INTRODUÇÃ̃

I. PRIMEIRA PARTE: DOS CONTRATOS DE COLABORAÇÃO ................................ 14

1. DAS CONSIDERAÇÕES PRELIMINARES .............................................................14

2. DA NATUREZA JURÍDICA DO INSTRUMENTO ................................................30

2.1 Da Natureza de Contrato.......................................................................................... 30

2.2 Da Natureza de Fomento Administrativo ……………………………………...... 39

3. DA NATUREZA JURÍDICA DAS PARTES...........................................................54

3.1 Das Entidades Paraestatais...................................................................................... 61

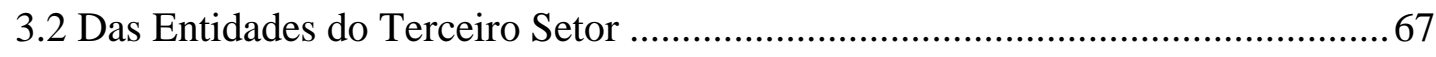

3.3 Das Alternativas Terminológicas..................................................................... 75

4. DA NATUREZA JURÍDICA DO OBJETO .............................................................80

II. SEGUNDA PARTE: DO REGIME JURÍDICO DOS CONTRATOS DE COLABORAÇÃ̃ ..................................................................................................................................... 93

1. DO REGIME DE SELEÇÃO DAS ENTIDADES DE COLABORAÇÃO .........93

2. DO REGIME DE PRESTAÇÃO DOS SERVIÇOS SOCIAIS ............................106

3. DO REGIME DE CONTRATAÇÃO PELAS ENTIDADES DE COLABORAÇÃ $O$......................................................................................................................119

4. DO REGIME DE CONTROLE ............................................................................126

CONCLUSÃO ........................................................................................................................... 136

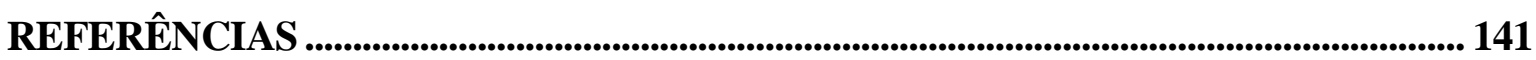




\section{INTRODUÇÃO}

Desde o final do século XX, o Estado Brasileiro recorre cada vez mais à celebração de contratos de colaboração para cumprir os seus misteres constitucionais e atender às necessidades coletivas, travando parcerias sociais com as entidades do terceiro setor.

Esse crescente processo de emparceiramento social entre os setores público e privado brasileiros ${ }^{1}$ é explicado, dum lado, pelo espírito democrático da Constituição Federal de 1988, promotora da reintronização dos cidadãos na discussão e realização dos negócios públicos ${ }^{2}$, e, doutro, pela Reforma Administrativa ${ }^{3}$ iniciada da década de 1990 em

\footnotetext{
${ }^{1}$ Neste estudo, os qualificativos público e privado serão frequentemente utilizados como sinônimos de estatal e não estatal respectivamente, não dizendo respeito à natureza de direito público ou de direito privado de determinada pessoa jurídica. Optou-se pela locução setores público e privado, ao invés de público-privado, para evitar confusões com as parcerias público-privadas tratadas na Lei Federal no 11.079/2004, espécie de contrato administrativo de concessão de serviço público. Não se olvida, contudo, a referência aos vínculos formais de cooperação travados entre a Administração e as organizações da sociedade civil sem fins lucrativos no setor social como parcerias público-privadas, a exemplo do que faz Carlos Ari SUNDFELD (2011, p. 2022), para quem a expressão parcerias público-privadas em sentido amplo corresponde aos "múltiplos vínculos negociais de trato continuado estabelecidos entre a Administração Pública e particulares para viabilizar o desenvolvimento, sob a responsabilidade destes, de atividades com algum coeficiente de interesse geral", incluindo os contratos de colaboração. De todo modo, em que pese a maior fluidez textual que a locução parceria social público-privada possa trazer, optamos por não a utilizar nesta dissertação como sinônimo de contratos de colaboração, preferindo falar em parcerias sociais entre os setores público e privado.

${ }^{2}$ Diogo de Figueiredo MOREIRA NETO (2008, p. 113) ensina que a noção objetiva de público como algo inerente e próprio, quando não exclusivo, do Estado é mito dominante do século XX, hoje substituído pela ideia de espaço decisório dum conjunto de interesses metaindividuais da sociedade compartilhado com o Estado, a romper com o presumido monopólio estatal sobre inúmeras funções de interesse transindividuais, historicamente por ele absorvidas. Segundo Luiz Carlos BRESSER PEREIRA (1999, p. 21), o público é entendido como o que é de todos e para todos; o privado é o que está voltado para o lucro ou para o consumo; e o corporativo é o que está orientado para a defesa política de interesses setoriais ou grupais; sendo possível distinguir dentro do público o estatal e o não estatal. Nessa mesma linha, José Roberto DROMI (1991, p. 06) afirma que "La Administración Pública es el género y la estatal una de las especies. Lo público no está solamente em manos del Estado. El Estado no es el único dueno y soberano de lo público, pues la 'administración de lo público' deben participar, también, los cuerpos intermedios que comprenden a las corporaciones profesionales, los sindicatos, los consórcios públicos, las cooperativas públicas, los concessionários de servicios públicos, las universidades privadas y otros modelos organizativos que crea la sociedade, em función del pluralismo social, para que detenten la defensa del interés de algunos que, junto al de los demás, es el interés de todos".

${ }^{3}$ Luiz Carlos BRESSER PEREIRA e Nuria Cunill GRAU (1999, p. 15-16) ensinam que o movimento reformista que se espalhou pelo mundo nas décadas de 1980 e 1990 decorreu da grave crise econômica que se verificava nos países em desenvolvimento - salvo os do Leste e Sudeste Asiático - e das baixas taxas de crescimento dos países desenvolvidos, tendo como sua principal causa a crise endógena do Estado Social ou Providência - do Estado do Bem-Estar nos países desenvolvidos, do Estado Desenvolvimentista nos países em desenvolvimento e do Estado Comunista, um Estado Social-Burocrático ineficiente e capturado por interesses particulares. Odete MEDAUAR (2003, p. 132) aponta como ideias de fundo dessa Reforma Administrativa do Estado a Administração a serviço do cidadão, a partir dum novo modelo de se relacionar com a sociedade; transparência e eficiência administrativas; a transferência de atribuições públicas [de interesse público] ao setor privado; e a expansão de práticas inspiradas no direito privado, acarretando, inclusive, técnicas de gestão que priorizam os resultados, o chamado new public management; tendo como eixos centrais, ao menos nos países periféricos como o Brasil, o controle da inflação e a busca do equilíbrio econômico, com a redução do
} 
nosso país, modificadora dos paradigmas da Administração Pública Brasileira, imprimindolhe matizes democráticas, pluralistas e consensuais, aproximando-a dos cidadãos na busca eficiente da concretização dos interesses públicos.

O delineamento panorâmico do regime jurídico dos contratos de colaboração fazse premente em razão da grande variedade de instrumentos negociais de que dispõe o Poder Público para se associar a entidades não estatais sem fins lucrativos e fomentar, de forma contínua, atividades socialmente relevantes, numa mixórdia legislativa prejudicial à segurança jurídica, de difícil compreensão não apenas para os especialistas do Direito, senão para a sociedade civil como um todo.

A importância desta dissertação é reafirmada pela publicação da recente Lei Federal $n^{\circ} 13.019 / 2014$, a qual se propõe a estabelecer "o regime jurídico das parcerias voluntárias, envolvendo ou não transferências de recursos financeiros, entre a administração pública e as organizações da sociedade civil, em regime de mútua cooperação, para a consecução de finalidades de interesse público", criando mais duas espécies de contrato de colaboração (termo de colaboração e termo de fomento), pretendendo submeter à sua disciplina, com algumas exceções e particularidades, todas as parcerias sociais entre o setores público e privado.

Como não podia deixar de ser, entretanto, não pretendemos fazer um exame minucioso de cada espécie de contrato de colaboração, como se possível fosse, numa dissertação de mestrado, analisar as peculiaridades normativas estabelecidas nas inúmeras leis e regulamentos que disciplinam a matéria, além de todas as controvérsias doutrinárias e jurisprudenciais existentes sobre o tema. Aquilo que intencionamos é construir, a partir da identificação das características jurídicas comuns desses instrumentos colaborativos, um regime jurídico mínimo de todo e qualquer vínculo formal de parceria social celebrados entre os setores público e privado, permitindo uma compreensão basilar e global desses mecanismos de emparceiramento.

\footnotetext{
aparelhamento administrativo e o controle da despesa pública. Tarso Cabral VIOLIN (2010, p. 97-109) explica que, no Brasil, esse movimento surgiu principalmente com a edição do Plano Diretor da Reforma do Aparelho do Estado - elaborado pelo Ministério da Administração Federal e Reforma do Estado (MARE) na gestão de Fernando Henrique Cardoso, cujo Ministro era justamente Luiz Carlos BRESSER-PEREIRA, orientada pelos postulados do Consenso de Washington, ocorrido em 1989 nesta localidade, reunindo os organismos de financiamento internacional de Bretton Woods (FMI, BID e Banco Mundial), funcionários do governo norteamericano e economistas latino-americanos, com o intuito especial de orientar o processo nos países em desenvolvimento -, em 1995, seguido pela reforma administrativa implementada pela Emenda Constitucional n $19 / 1998$ e por normas infraconstitucionais, a exemplo da edição da Lei Federal no 9.637/1998, que instituiu e disciplinou os contratos de gestão com as organizações sociais.
} 
$\mathrm{Na}$ Primeira Parte deste trabalho, então, serão investigados os fatores que determinam o regime jurídico dos contratos de colaboração, aquelas características suas atrativas dum conjunto específico de normas jurídicas. De forma mais técnica, identificandose o conceito jurídico de cada elemento do contrato de colaboração (partes, objeto, instrumento), buscar-se-á qualificá-los, ordená-los e encaixá-los em categorias jurídicas preexistentes, cuja referência determinará a incidência de um plexo de normas jurídicas, ativando estatutos jurídicos próprios ${ }^{4}$.

Como dito, todavia, esse encastramento em categorias jurídicas será responsável apenas pelo tracejo da generalidade da disciplina normativa dos contratos de colaboração, definindo os princípios e regras básicos que orientam a sua celebração e funcionamento, jamais olvidando que, a depender do instrumento colaborativo efetivamente empregado, a parceria se sujeitará a diplomas legais e infralegais específicos.

É nessa perspectiva que a presente dissertação propõe a construção dum regime jurídico mínimo/comum para os contratos de colaboração, em reconhecimento de que um tratamento normativo nuclearmente uniforme para essas parcerias é indispensável à segurança jurídica e à proteção das legítimas expectativas tanto dos contratantes quanto de toda a sociedade, contribuindo para o bom funcionamento do regime de mútua cooperação estatal-não estatal no setor social brasileiro e, no limite, para o estímulo à participação popular nos negócios públicos, o melhor atendimento das necessidades coletivas e a realização dos direitos fundamentais.

Nesse diapasão, a Primeira Parte deste estudo explorará a natureza jurídica [qualificação através de categorias jurídicas predeterminadas] dos elementos do contrato de colaboração, definindo os plexos normativos por eles atraídos, que, em conjunto, conformam o regime jurídico mínimo/comum dessas parcerias sociais entre os setores público e privado: (i) do instrumento colaborativo (contratual e instrumental de fomento administrativo); (ii)

\footnotetext{
4 Flávio GALDINO (2005, p. 105-107;123) leciona que, numa perspectiva convencionalista/instrumentalista/nominalista, os conceitos jurídicos são representações abstratas dum objeto juridicamente relevante, que, qualificados e ordenados segundo determinados critérios pelo operador do Direito, resultam as categorias jurídicas, as quais nada mais são do que operações de qualificação e ordenação dos conceitos jurídicos [o Autor não desconsidera outros sentidos de categoria jurídica, citando o entendimento de José CRETELLA JR., para quem as categorias jurídicas seriam figuras genéricas, puras, livres de especificidades que as vinculassem a determinado ramo do Direito]. O Autor entende que a principal função dos conceitos e categorias jurídicas é justamente auxiliar o operador jurídico na aplicação dos assim chamados regimes jurídicos, "redes mais ou menos complexas de normas jurídicas que determinam a constituição de situações para pessoas". Para o Autor, as categorias jurídicas são verdadeiros “ativadores de regimes jurídicos", na medida em que a sua simples referência faz detonar uma série de consequências jurídicas, cujo conjunto constitui o respectivo regime jurídico.
} 
das partes contratantes (estatal e não estatal sem fins lucrativos de finalidade social); e (iii) do objeto contratado (serviço social enquanto serviço de relevância pública).

É indispensável uma visão conjunta que permita discernir as efetivas implicações de cada um desses elementos na relação colaborativa, a determinar aquele que, conforme o aspecto/momento da parceria, revele-se, sem o sacrifício dos demais, preponderante na definição das normas jurídicas incidentes. Nesse trilhar, buscaremos organizar o regime jurídico dos contratos de colaboração através da interpenetração de todas essas categorias jurídicas, rechaçando construções teóricas que partam da eleição dum ou doutro elemento apenas, ora voltadas, ainda que em detrimento dos interesses públicos, à predominância intransigente da autonomia das entidades não estatais envolvidas, ora apegadas a uma concepção estatista de Administração Pública, restritiva da ação dos particulares, encarados como meros administrados ou, no máximo, delegatários do Estado 5 .

Tomaremos o cuidado de não promover extensões indevidas do Direito Público ${ }^{6}$ ao funcionamento do terceiro setor, não se admitindo que, simplesmente em virtude dos interesses públicos que permeiam os seus objetivos sociais e dos recursos públicos transferidos à sua gestão privada, sejam tais entidades não estatais submetidas ao tratamento reservado aos órgãos e pessoas administrativas. Esse raciocínio vale, com efeito, mesmo quando essas organizações se emparceiram com o Estado, através de contrato de colaboração, para potencializar a sua ação social, uma vez que qualquer limitação à esfera de liberdade dos particulares reclama expressa previsão legal.

\footnotetext{
${ }^{5}$ Segundo pensamos, muitas das perplexidades enfrentadas no estudo dos contratos de colaboração decorrem justamente das visões parciais encontradas na doutrina e jurisprudência nacionais, que não levam em conta todos os elementos presentes nas parcerias sociais entre os setores público e privado, desconsiderando, por conseguinte, a composição heterogênea do seu regime jurídico. Perfeito é para nós, então, a visão de conjunto de Paulo Eduardo Garrido MODESTO (2011, p. 07) sobre o tema, segundo o qual o Direito Administrativo se aplica parcialmente às entidades de colaboração pela expressiva presença do interesse público, "seja pelo fato da atividade referida encerrar a aplicação vinculada de recursos públicos, seja pela notória relevância pública da atividade desenvolvida ou ainda por manter a atividade estreitos vínculos com a proteção de direitos fundamentais do cidadão e com deveres de garantia do próprio Estado".

${ }^{6}$ Investigando a evolução histórica da distinção entre Direito Público e Direito Privado, e reconhecendo que os critérios utilizados são topoi, isto é, lugares-comuns que admitem classificações regionais ou provisórias, muitas vezes confusas e sem nitidez, Tércio Sampaio FERRAZ JUNIOR (2008, p. 104-111) destaca que a dicotomia ainda persevera em todo o mundo, permitindo a sistematização dos princípios teóricos básicos para operar as normas de um ou de outro grupo, funcionando como um "instrumento sistematizador do universo normativo para efeitos de decidibilidade". Nesta toada, o Autor ensina que o Direito Público é orientado pelo princípio da soberania, segundo o qual a lei, que encarna a vontade social, é a verdadeira soberana, conferindo competência para a manifestação do jus imperii. Deste modo, envolvendo a realização do interesse público, as suas normas seriam cogentes, a restringir a liberdade dos sujeitos envolvidos. Diferentemente, seria o princípio da autonomia a viger no Direito Privado, de modo que os entes privados gozam da capacidade de estabelecer normas conforme os seus interesses. Nada obstante, ele ressalva que, em ambos, deve-se observar o princípio da legalidade como um limite, a delinear a edição de atos soberanos e restringir a liberdade de ação dos agentes privados.
} 
Inseridos os elementos dos contratos de colaboração em categorias jurídicas próprias, definindo-se os plexos de normas jurídicas incidentes em cada uma dessa categorizações, a Segunda Parte desta dissertação ingressará na efetiva construção do regime jurídico mínimo/comum dessas parcerias sociais entre o setor público e o setor privado.

Começaremos com o regime de seleção das entidades de colaboração, especificando, sempre com referência aos fatores explorados na Primeira Parte deste trabalho, os princípios que orientam a ação administrativa de fomento e a celebração em si das parcerias sociais entre o setor público e o setor privado, estabelecendo as regras imperativas que devem ser observadas pelo Poder Público na escolha da entidade, sem jamais descurar da autonomia privada dessas pessoas não estatais interessadas no emparceiramento com o Estado.

Na sequência, trataremos do regime de prestação colaborada dos serviços sociais, ganhando relevo, neste momento, a natureza de serviço de relevância pública das atividades prestadas e a natureza pública dos recursos transferidos pela Administração às entidades de colaboração. Aqui, tentar-se-á equilibrar os fundamentos/garantias constitucionais da livre iniciativa, da liberdade de associação e da participação democrática com os imperativos da realização do interesse público e da proteção dos direitos fundamentais. De especial importância será a conformação das obrigações positivas legalmente impostas às entidades privadas de colaboração com o intransponível direito dessas organizações não estatais de definir a abrangência e modo da sua atuação social e de encerrar as suas atividades quando assim lhes aprouver.

Avançando mais um pouco, chegaremos ao regime de contratação de terceiros pelas entidades de colaboração, aspecto em que será decisiva a natureza pública dos recursos transferidos a essas organizações parceiras do Estado, os quais permanecem vinculados aos objetivos públicos pré-definidos em nosso ordenamento jurídico e no instrumento contratual celebrado e às diretrizes do new public management.

Por fim, delinearemos o regime de controle dos contratos de colaboração, explorando as modalidades de controle (interno/externo, de meios/de resultados), destacando a obrigação do parceiro privado de prestação de contas, através da apresentação de balanços e demonstrações financeiras. 


\section{PRIMEIRA PARTE: DOS CONTRATOS DE COLABORAÇÃO}

\section{DAS CONSIDERAÇÕES PRELIMINARES}

Os contratos de colaboração são expressão do chamado direito fundamental de participação social nos negócios públicos ${ }^{7}$, verdadeiro imperativo democrático reconhecido e sobrelevado pela Constituição Federal de 1988, cuja marca cidadã devolveu à sociedade a titularidade primária dos interesses públicos, cabendo ao Estado, instrumento do atendimento das necessidades coletivas e de proteção dos direitos fundamentais que é, intervir preferencialmente através do fomento administrativo, estimulando a iniciativa privada dirigida à realização de interesses públicos, em especial por meio dessas parcerias sociais entre os setores público e privado.

No contexto da Reforma Administrativa da década de 1990, em reconhecimento da incapacidade do Estado Brasileiro de cumprir a contento os seus deveres constitucionais, o contrato de colaboração instrumentaliza a busca por eficiência no atendimento das necessidades coletivas, a superar a excessiva burocracia das estruturas administrativas, além de pluralizar, ampliar e dinamizar a oferta de serviços sociais aos cidadãos ${ }^{8}$.

\footnotetext{
${ }^{7}$ De acordo com Diogo de Figueiredo MOREIRA NETO (2008, p. 114-115), para além de desejável, a participação democrática é inevitável numa sociedade permeada pela comunicação, refletindo a transformação do tipo do Estado monoclasse/biclasse para um Estado pluriclasse, em que a Administração Pública também precisa se pluralizar para atender, mais direta e significativamente, os vários setores de interesses transindividuais que vão emergindo e reclamando disciplina jurídica e atuação gerencial. Num Estado agente de fomento público, cresceria o acionariato popular, de modo que a Administração Pública, transcendendo a fase demagógica de mera assistência paternalista, "passa a proporcionar um real estímulo educacional, voltado ao desenvolvimento das aptidões individuais e empresariais das pessoas, para enfrentarem a competição pelo progresso econômico e social". Em resumo, para o Autor, o Estado troca a assistência pelo estímulo, numa receita segura e duradoura de progresso que prepara cidadãos úteis e responsáveis.

${ }^{8}$ Cético, Sílvio Luís Ferreira da ROCHA (2006, p. 38) afirma que os argumentos em favor dessa Reforma são financeiros, jurídicos e políticos, partindo da premissa, não comprovada por nenhuma experiência histórica recente, de que haveria, ao final do processo, uma melhoria na capacidade do Estado de atender as demandas sociais. Em contraponto a essa crítica, Luiz Carlos BRESSER PEREIRA e Nuria Cunill GRAU (1999, p. 3034), afirmam que, conquanto os estudos sobre a maior eficiência da prestação dos serviços sociais por entidades privadas sem fins lucrativos não sejam conclusivos e que careçam de comparações rigorosas quantitativa e qualitativamente, a principal razão para se recorrer a tais organizações não é a maior eficiência no serviço, mas, sim, porque elas permitem o desenvolvimento de papéis que nem o Estado nem o mercado podem cumprir: fortalecimento da solidariedade, participação e responsabilidade social na gestão e provisão das atividades sociais; e acesso a clientes difíceis de serem alcançados, por meio do ajuste das prestações às características e necessidades de destinatários específicos, com forte aporte à diversidade.
} 
Afina-se, nessa esteira, com a chamada Administração Pública Gerencial, a qual, segundo Luiz Carlos BRESSER PEREIRA (1996, p. 04-06), resulta desse movimento de reforma e incorpora ao burocratismo - pautado pelos princípios do mérito profissional, legalidade e controle de meios - ideais de descentralização político-administrativa, organização em poucos níveis hierárquicos, pressuposto da confiança legítima, controle de resultados ou posterior e foco no atendimento ao cidadão.

Nessa onda reformista, de busca de instrumentos administrativos mais democráticos, flexíveis e eficientes para a realização dos interesses públicos, é que se construiu a noção de Estado Parceiro ${ }^{9}$, aquele que, reconduzindo o homem à centralidade do jogo político, econômico e social, assegurando-lhe o direito fundamental de participação nos negócios públicos, despe-se - ainda que parcialmente - da roupagem monocromática da autoridade e supremacia para, por meio da consensualidade ${ }^{10}$, absorver ferramentas de colaboração com a iniciativa privada para o cumprimento dos seus deveres constitucionais, especialmente por meio dos aqui estudados contratos de colaboração.

Contrato de colaboração, entretanto, é locução que, no Direito Brasileiro, diante da ausência dum conceito legal, pode designar situações jurídicas essencialmente distintas. Sem grande consenso na doutrina e jurisprudência nacionais, verificam-se aqueles que simplesmente não utilizam a expressão como uma categoria jurídica própria [previamente

\footnotetext{
${ }^{9}$ Diogo de Figueiredo MOREIRA NETO (2008, p. 21-23) explica a evolução do papel do Estado na seguinte sequência: (i) Estado de Polícia ou Gendarme, de garantia do homem livre - liberalismo; (ii) Estado Providência, de garantia da igualdade material, próprio dos séculos XIX e XX e marcado pela concentração de poder e hipertrofia do aparelho estatal, cortes autocráticos e absolutistas nas versões mais radicais, desequilíbrio entre a liberdade e a igualdade e Estado como tutor ou dirigente da coletividade; e (iii) Estado Parceiro, que reintroniza o homem como responsável e destinatário do progresso, reinstilando a confiança em suas potencialidades elementares, encarando-se o corpo estatal como mero instrumento de realização dos interesses coletivos, não mais cabendo ao ente estatal a tarefa de dirigir, mas a de executar a vontade de sociedades abertas. Para o Autor (2006, p. 379), o Estado Parceiro, longe de diminuir, ganhará importância, já que, fortalecido pela segurança ética que lhe dará o princípio da subsidiariedade, concentrará sua ação em seu próprio campo decisional - o da finalidade pública -, uma vez que esta somente pode ser realizada efetivamente com sua ação. De acordo com Luis Martin REBOLLO (2003, p. 111), o Estado Parceiro é "Um Estado que agora, sobretudo, regula, inspeciona, sanciona. Acentua esse papel vigilante, sem prejuízo de que às vezes preste diretamente serviços". Referindo-se à doutrina de Gaspar Ariño ORTIZ, Gustavo Justino de OLIVEIRA (2007c, p. 223-226) prefere falar em Estado contratual e Estado financiador, figuras que seriam complementares entre si e expressariam a vocação do Estado contemporâneo de funcionar como "[...] agente financiador e fomentador de atividades que tenham por fim gerar a transformação social”.

${ }^{10}$ Almiro do Couto e SILVA (2013, p. 429) leciona que Administração Concertada, Administração Consensual ou Soft Administration são expressões que refletem novas formas de democracia participativa, em que o Poder Público, ao invés de decidir unilateralmente, utilizando-se do ato administrativo, procura ou atrai os indivíduos para o debate de questões de interesse comum, que deverão ser resolvidas mediante acordo. Sílvio Luís Ferreira da ROCHA (2006, p. 20) afirma que o modelo estatista levou à transformação duma Administração impositiva e burocrática noutra consensual e gerencial, substituindo-se o modelo clássico da coerção pelo da colaboração, num sistema de gestão baseado em instrumentos consensuais e negociais.
} 
delimitada e convencionada, atrativa dum regime jurídico específico], bem como os que a empregam num sentido completamente distinto do proposto no presente trabalho.

De forma genérica, pode-se falar em colaboração entre o Estado e entes não estatais tanto no âmbito das atividades industriais e comerciais - voltadas à produção de bens e serviços ao mercado - quanto no das atividades sociais - dirigidas ao atendimento imediato das necessidades coletivas de cunho assistencial e prestadas com ou sem finalidade lucrativa.

É justamente nessa perspectiva ampla que Diogo de Figueiredo MOREIRA NETO (2008, p. 116) vale-se da palavra colaboração para se referir a todas as formas de sinergia entre o Estado e a iniciativa privada na realização do interesse público, este que se flexibiliza através da consensualidade, numa negociação de interesses metaindividuais, criando um campo de debate aberto de intensa participação social ${ }^{11}$.

Em grande medida, essa acepção larga de colaboração corresponde à noção de parcerias defendida por Maria Sylvia Zanella DI PIETRO (2015, p. 24-25), designativa de “todas as formas de sociedade que, sem formar uma nova pessoa jurídica, são organizadas entre os setores público e privado, para a consecução de fins de interesse público". Para a Autora, essas parcerias entre os particulares e o Poder Público podem ter objetos: (i) delegação de serviços públicos econômicos a particulares, através das tradicionais

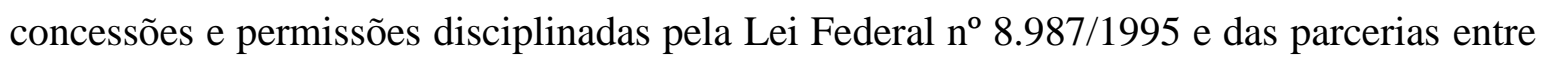
o setor público e o setor privado regidas pela Lei Federal no 11.079/2009; (ii) fomento à chamada iniciativa privada de interesse público, por meio de convênios, contratos de gestão ou termos de parceria ${ }^{12}$; e (iii) as formas de cooperação dos particulares na execução de atividades próprias da Administração Pública, pelo instrumento da terceirização (contratos de prestação de serviços, obras e fornecimento, sob a forma de empreitada regida pela Lei

\footnotetext{
${ }^{11}$ Conforme se esclarecerá adiante, o Autor (2014: 207-208) distingue os acordos cooperativos celebrados pela Administração Pública - entre órgãos e entidades administrativas - daqueles ditos colaborativos, estes designativos justamente da associação de pessoas administrativas e entidades não estatais.

${ }^{12}$ Segundo pensamos, podem ser acrescentados à segunda categoria apontada pela Autora (instrumento de fomento à iniciativa privada de interesse público) todos os ajustes firmados entre o Estado e a iniciativa privada para o incentivo a atividades industriais e comerciais, que, ao se desenvolverem, produzem as chamadas externalidades positivas, verdadeiros benefícios indiretos - de caráter econômico, social, cultural ou ambiental - auferidos pela coletividade afetada/implicada/relacionada ao empreendimento lucrativo estimulado. É que o Estado exerce o fomento administrativo também em relação às atividades econômicas em sentido amplo, sejam elas de fornecimento de bens e serviços industriais ou comerciais, sejam prestações sociais desenvolvidas sob a ótica empresarial. O fomento administrativo será examinado com maior vagar a seguir.
} 
Federal nº 8.666/1993 - Lei Geral de Licitações, ou de concessão administrativa, regida pela Lei Federal no $11.079 / 2009)^{13}$.

No presente trabalho, entretanto, a expressão contratos de colaboração não é utilizada nesse sentido amplo, desprovido de juridicidade, sem qualquer congruência de regime jurídico entre os instrumentos de parceria envolvidos ${ }^{14}$. Aqui, ela é empregada num sentido técnico, o que, em Direito, significa reunir sob essa mesma alcunha apenas aqueles ajustes que compartilhem duma unidade mínima de regime jurídico, vale dizer, que estejam sujeitos à incidência das mesmas normas jurídicas-base.

É nessa esteira que conceituamos o contrato de colaboração como todo e qualquer instrumento negocial de caráter continuado ${ }^{15}$ firmado entre o Poder Público e as organizações não estatais sem fins lucrativos para a prestação colaborada de serviços sociais.

É gênero que permite, independentemente da denominação empregada na legislação própria, a reunião todos os instrumentos jurídicos habilitantes de parcerias sociais entre os setores público e privado. Viabiliza, a partir da identificação da unidade de sentido

${ }^{13}$ De forma similar, conforme já anotado na Introdução do presente trabalho, Carlos Ari SUNDFELD (2011, p. ) prefere se referir a parcerias público privadas em sentido amplo para designar todas as ferramentas negociais de caráter continuado firmados entre a Administração e particulares para a viabilização, sob a responsabilidade destes, de atividades de interesse geral, incluindo: os mecanismos de delegação de serviços públicos, a exemplo da concessão e permissão disciplinadas pela Lei Federal 8.987/1995; os instrumentos atribuição do uso privado de bens públicos em atividade de relevância social; e, finalmente, os instrumentos de cooperação estatal-não estatal nos serviços sociais, tal qual o contrato de gestão com as Oss e os termos de parceria com as OSCIPs. Gustavo Justino de OLIVEIRA (2007c, p. 224), por sua vez, fala em parcerias em sentido amplo e em parcerias em sentido estrito: as primeiras seriam toda e qualquer convenção que une os setores público, privado e associações da sociedade civil; as segundas, “[...] as diversas colaborações públicoprivadas instituídas em leis especiais, a exemplo da Lei federal $\mathrm{n}^{\circ} 11.079 / 04$, a qual criou o contrato administrativo de parceria público-privada (PPP) e da Lei federal n ${ }^{\circ}$ 9.790/99, a qual criou o Termo de Parceria das OSCIP".

${ }^{14}$ Segundo os preciosos ensinamentos de Celso Antônio Bandeira de MELLO (2009, p. 158-159), a taxonomia só se presta a oferecer rotulação para objeto símiles, similaridade esta que, em Direito, é a de regime jurídico, de modo que "[...] um nomen juris só pode corresponder a um signo breve para nominar coisas juridicamente equiparáveis pelos princípios e normas que os regulem”. Nesse mesmo sentido, Flávio GALDINO (2005, p. 123) afirma que os conceitos e categorias jurídicas deverão observar um critério de utilidade/operatividade, o qual, para o Direito, nada mais é do que a atração de um regime jurídico específico.

15 É fundamental essa noção de trato sucessivo para a caracterização do contrato de colaboração, não se devendo confundir esses ajustes negociais com instrumentos de fomento estatal que não impliquem a formação duma relação continuada de parceria social entre o Estado e as entidades da sociedade civil sem fins lucrativos. Trata-se do entendimento da mais respeitada doutrina brasileira, a exemplo de Maria Sylvia Zanella DI PIETRO (2015, p. 24-25), que afirma se tratar de forma de sociedade não personalizada organizada entre os setores público e o privado para a consecução de fins de interesse público, deixando clara a extensão da relação colaborativa no tempo. Da mesma forma, Carlos Ari SUNDFELD (2011, p. 20) chama de parcerias apenas aqueles instrumentos negociais que, criando direitos e obrigações, se prolongam no tempo, fazendo surgir justamente o "desafio de disciplinar a convivência entre os contratantes e de definir como se partilham as contribuições e responsabilidades para o atingimento dos objetivos, bem assim os riscos decorrentes do empreendimento. 
existente entre as mais variadas ferramentas de cooperação estatal-não estatal no setor social, um tratamento jurídico minimamente uniforme desse universo colaborativo, conferindo-lhe coerência, fortalecendo a segurança jurídica nessas relações, e, com força maior, impulsionando a participação social na realização do interesse público.

A nossa opção terminológica não é aleatória nem de criação própria, tratando-se de expressão consagrada no art. 75 do Anteprojeto de Normas Gerais sobre a Administração Pública Direta e Indireta, as Entidades Paraestatais e de Colaboração ${ }^{16}$, o qual pretendeu justamente estabelecer diretrizes jurídicas comuns para todos os ajustes de parceria firmados nos chamados serviços de relevância pública, concepção esta abrangente das atividades, ações e programas de interesse público que tanto podem ser prestados pelo Poder Público quanto pela iniciativa própria do particular, admitindo, com mais força, exatamente o regime de cooperação estatal-não estatal ${ }^{17}$.

O contrato de colaboração aqui estudado se insere na noção ampla de convênio administrativo, entendido, na esteira dos ensinamentos de Hely Lopes MEIRELLES (2002, p. 383), como “[...] acordos firmados por entidades públicas de qualquer espécie, ou entre estas e organizações particulares, para realização de objetivos de interesse comum”.

De forma mais precisa, o contrato de colaboração ora tratado corresponde à categoria do convênio administrativo colaborativo, instrumental das parcerias da Administração com entidades privadas sem fins lucrativos. Sucede que os convênios possuem multifuncionalidade no sistema administrativo brasileiro, podendo ser encarados tanto como um acordo administrativo organizatório, quanto como um acordo administrativo colaborativo: o primeiro instrumentaliza a descentralização de atividades de um órgão ou ente administrativo para outros órgãos ou entes administrativos; e o segundo

\footnotetext{
16 Trata-se de Anteprojeto elaborado por uma Comissão de juristas constituída pela Portaria 426/2007, do Ministério do Planejamento, Orçamento e Gestão do Governo Federal, entregue oficialmente em 16 de julho de 2009 propondo uma nova estrutura orgânica para o funcionamento da Administração Pública Federal e das suas relações com entes de colaboração. Os trabalhos desenvolvidos na elaboração deste Anteprojeto deram origem à preciosa obra Nova Organização Administrativa Brasileira, livro coordenado pelo Professor Paulo Modesto e que reúne artigos dos membros da Comissão. Como bem observa o Ex-Ministro Paulo Bernardo, “[...] O Anteprojeto não é uma simples lei de estruturas e organização, mas de definição jurídico-legal dos entes que constituem a administração pública em seu espaço ampliado de atuação institucional, dos princípios a que estão submetidos e dos seus instrumentos e mecanismos de planejamento, articulação e controle" (Paulo Eduardo Garrido MODESTO, 2010, p. 15).

${ }^{17}$ Embora respalde a opção aglutinadora do Anteprojeto, Fernando Dias MENEZES DE ALMEIDA (2012, p. 241) assevera que, salvo no caso das figuras que importam criação de pessoas jurídicas distintas - como ocorre com os consórcios públicos -, talvez seria mais interessante que a legislação desse um tratamento unificado a todos esses ajustes de cooperação sob o já consagrado rótulo de convênio, com margem para que a Administração pudesse modelar detalhes do regime jurídico às situações concretas.
} 
formaliza vínculos de colaboração entre a Administração e quaisquer tipos de entidades privadas, com ou sem fins lucrativos, independentemente de serem detentoras de uma qualificação especial prévia (Gustavo Justino de OLIVEIRA, 2008b, p. 269-270) ${ }^{18}$.

Em igualdade de sentido, Gustavo Alexandre MAGALHÃES (2012, p. 116-117) conclui que o termo convênio abrange:

[...] todos os vínculos jurídicos celebrados entre a Administração Pública, no exercício da atividade de fomento, e os entes no exercício de atividades referentes ao terceiro setor [...], [tratando-se de] acordos de vontade, em que os partícipes visam a um interesse comum, colaborando mutuamente para o desenvolvimento do projeto. [...] [Dessa forma,] todo o estudo realizado acerca dos convênios administrativos (principalmente quanto à natureza jurídica) aplica-se também aos contratos de gestão, termos de parceria e eventuais outros institutos criados por leis específicas no intuito de regular os acordos celebrados entre entes públicos e instituições sem fins lucrativos, para atender a objetivos comuns.

Esse também é o pensamento de José dos Santos CARVALHO FILHO (2013, p. 360; 363) e Maria Sylvia Zanella DI PIETRO (2015, p. 293-294), esta última para quem, quanto à sua natureza, os termos de parceria com as organizações da sociedade civil de interesse público [e os recentes termos de fomento e de colaboração] assemelha-se aos convênios tradicionalmente celebrados entre o Poder Público e entidades privadas para

\footnotetext{
${ }^{18}$ Carolina Caiado LIMA (2010, p. 30-36) explica que os convênios administrativos se subdividem em: (i) convênios administrativos de cooperação federativa, previstos no art. 241 da Constituição Federal de 1988 e celebrados por entidades estatais para a gestão associada de serviços públicos, ou para a colaboração em atividades privativas do Estado, como o poder de polícia e a administração tributária; e (ii) convênios administrativos colaborativos ou de cooperação, firmados entre o Poder Público e entidades privadas (com ou sem fins lucrativos) com o objetivo de incentivar, no contexto da atividade administrativa de fomento, ações e atividades privadas [leia-se, não submetidas a qualquer monopólio ou privilégio estatal] afetadas ao interesse público e coletivo. Esta Autora (2010, p. 30) entende não existir diferença alguma entre as expressões colaboração e cooperação em nosso Direito, sendo válida a observação de Miriam Cavalcanti de Gusmão Sampaio TORRES (1999, p. 389) no sentido de que foi apenas com a Constituição de 1988 que a noção de cooperação e convergência de interesses para a realização de objetivos comuns se fez mais presente nos convênios administrativos, de modo que, transbordando-se a ideia de instrumento federativo de delegação de funções (já presente nas Constituições Brasileiras anteriores, salvante a de 1824), eles passaram a servir também às parcerias entre o Poder Público e as entidades da sociedade civil no atendimento das necessidades coletivas, a exemplo da previsão contida no parágrafo primeiro do artigo 199 da Constituição Brasileira atual. Registre-se, contudo, a posição de Diogo de Figueiredo MOREIRA NETO (2014, p. 207-208), que distingue esses dois tipos de coordenação de vontades e de ação: (i) cooperação, em que as pessoas acordantes seriam todas estatais (ou paraestatais), voltando-se ao desempenho de uma atividade que a ordem jurídica acomete a pelo menos uma delas; e (ii) colaboração, na qual as pessoas administrativas se valeriam das atividades desenvolvidas por particulares (não estatais), preparatórias, auxiliares, substitutivas ou complementares àquela função atribuída pela ordem jurídica ao acordante administrativo. Os contratos de colaboração tratados no presente trabalho se inserem neste segundo grupo. Não diferenciaremos na presente dissertação colaboração de cooperação, utilizando-se essas expressões como sinônimas, em seu sentido comum do léxico, orientação que parece ter sido encampada pela recente Lei Federal nº 13.019/2014, que, tratando das parcerias voluntárias celebradas entre a Administração Pública e as organizações da sociedade civil sem fins lucrativos nos serviços sociais, consigna expressamente se tratar de regime de mútua cooperação.
} 
formalizar a atividade de fomento, tratando-se de "[...] acordo de vontades em que os partícipes objetivam a um fim de interesse comum; cada qual colabora de uma forma, podendo ser por meio de recursos humanos, materiais, financeiros, know how (...)"19.

Da mesma forma, embora prefira a expressão módulos convencionais de cooperação para designar todos esses vínculos obrigacionais celebrados pela Administração Pública em regime de conjunção de esforços para um fim comum, Fernando Dias MENEZES DE ALMEIDA (2012, p. 240-246) nota que a Lei Federal nº 8.666/1993 refere um sentido amplo de convênio, na medida em que o trata em conjunto com "acordos, ajustes e outros instrumentos congêneres" (art. 116). Para o Autor, então, convênios em sentido amplo [na espécie colaborativa] designariam, no plano federal, os contratos de repasse, os contratos de gestão com organizações sociais e os termos de parceria com organizações da sociedade civil de interesse público ${ }^{20}$.

Finalmente, perfilhando esse mesmo entendimento, Carolina Caiado LIMA (2010: 30 e 37) observa não haver, ao menos na esfera federal, uma definição legal de convênio administrativo (em quaisquer de suas espécies, organizatórios/de cooperação federativa ou colaborativos), existindo apenas diretrizes genéricas no art. 116 da Lei de Federal $n^{\circ}$ 8.666/93 e no art. 13 da Lei Federal $n^{\circ} 11.107 / 2005$, às quais se somam previsões esparsas contidas na legislação setorial dos serviços públicos e programas de fomento, não se devendo esquecer ainda do vasto universo de normas infralegais, a exemplo do Decreto Federal $\mathrm{n}^{\circ}$ 6.170/2007 (art. $1^{\circ}, \S 1^{\circ}$, I), da Portaria Interministerial MP/MF/CGU n ${ }^{\circ}$ 507/2011 (art. $1^{\mathrm{o}}, \S$ $\left.2^{\circ}, \mathrm{VI}\right)$ e da IN STN n ${ }^{\circ} 01 / 97\left(\operatorname{art.} 1^{\circ}, \S 1^{\circ}, I\right)$, que se limitam a defini-los como acordos ou ajustes para transferência de recursos ${ }^{21}$.

\footnotetext{
${ }^{19}$ Registre, ainda, o similar vaticínio de Diogo de Figueiredo MOREIRA NETO (2014, p. 610-612), segundo o qual "a esses atos caberia adequadamente a denominação de convênios". Negando a natureza contratual dos acordos de colaboração, o Autor critica duramente a designação "contrato de gestão" prevista na Lei Federal $\mathrm{n}^{\circ}$ 9.637/1998, afirmando que nem mesmo a expressão "termo de parceria" da Lei Federal no 9.790/1999 seria adequada, já que "ignora a correta e pacífica denominação de convênios [de cooperação], já adotada pelo legislador constitucional para instrumentar a gestão associada de serviços públicos (CF, art. 241) [grifos no original]. Ousamos discordar do Autor neste último ponto, entretanto, dado que o aludido dispositivo constitucional se refere aos convênios interfederativos, cuja alusão somente traria dificuldades quanto às normas jurídicas aplicáveis, embora não olvidemos da previsão constitucional de convênios entre o Poder Público e as organizações da sociedade civil sem fins lucrativos na área da saúde (art. 199, § $1^{\circ}$ ).

${ }^{20}$ A edição consultada é de 2012, razão pela qual Fernando Dias MENEZES DE ALMEIDA não tratou dos noveis termos de colaboração e de fomento.

${ }^{21} \mathrm{O}$ que sequer é correto, dado que os convênios colaborativos não pressupõem a transferência de recursos públicos a entidades da iniciativa privada sem fins lucrativos, podendo, ao menos em tese, ser firmados para viabilizar qualquer espécie de fomento administrativo, a exemplo do apoio técnico, mediante o treinamento de pessoal e o compartilhamento de know-how.
} 
Temos, portanto, que, no âmbito federal brasileiro, o contrato de colaboração [convênio administrativo colaborativo, firmado com organizações da sociedade civil sem fins lucrativos de fins públicos] abrange as figuras do convênio em sentido próprio ${ }^{22}$ e contrato de repasse, do contrato de gestão com as organizações sociais - OSs (Lei Federal $\mathrm{n}^{\circ}$ 9.637/1998), do termo de parceria com as organizações da sociedade civil de interesse público - OSCIPs (Lei Federal no 9.790/1999 e Decreto Federal no 3.100/1999) ${ }^{23}$ e dos recentes termo de colaboração e termo de fomento (Lei Federal no 13.019/2014) ${ }^{24}$.

\author{
Começando pelo convênio propriamente dito [e contrato de repasse ${ }^{25}$ ], Janaina \\ SCHOENMAKER (2011, p. 58) adverte que se tratar do mais tradicional e utilizado ${ }^{26}$ \\ instrumento de transferência voluntária de recursos públicos federais às instituições privadas
}

${ }^{22}$ Fala-se em convênios em sentido próprio, específico, como se forma diferenciada de acordo colaborativo fosse, na medida em que o sistema jurídico brasileiro traz prescrições normativas restritas aos ajustes de cooperação assim intitulados, a exemplo do Decreto Federal n n 6.170/2007 (que dispõe sobre "transferências de recursos da União mediante convênios e contratos de repasse [...]") e a Instrução Normativa STN n n 01/1997 (que "disciplina a celebração de convênios de natureza financeira que tenham por objeto a execução de projetos ou a realização de eventos"), que regulam os instrumentos de parceria firmados apenas sob a alcunha de convênio ou contrato de repasse, não se aplicando aos contratos de gestão com organizações sociais (Lei Federal no 9.637/1998), aos termos de parceria com organizações da sociedade civil de interesse público (Lei Federal $\left.n^{\circ} 9.790 / 1999\right)$, nem aos noveis termos de colaboração e termo de fomento firmados com organizações da sociedade civil (Lei Federal no 13.019/2014).

${ }^{23} \mathrm{O}$ art. $4^{\circ}$ da novel Lei Federal no 13.019/2014 determina a sua aplicação subsidiária aos termos de parceria com organizações da sociedade civil sem fins lucrativos, sempre que compatível com as disposições da Lei Federal $n^{\circ}$ 9.790/1999.

${ }^{24}$ Rodrigo Pagani de SOUZA (2009, p. 312) questiona a concorrência desses instrumentos de parceria entre o Poder Público e as organizações da sociedade civil sem fins lucrativos em nosso ordenamento jurídico diante da igualdade de propósito entre eles, afirmando ser essa redundância um dos problemas fundamentais do Direito vigente. Para o Autor, essa multiplicidade de regimes de parceria traz complexidade desnecessária ao Direito positivo brasileiro, permitindo o tratamento desigual de entidades que, fundamentalmente, se encontram na mesma situação. Interessante observar que a crítica do Autor permanece atual mesmo após o advento da Lei Federal $\mathrm{n}^{\circ}$ 13.019/2014, a qual pretende conviver com os contratos de gestão e termos de parceria (art. $2^{\circ}$, VII e VIII), determinando ainda a sua aplicação subsidiária ("naquilo que couber") a estes últimos (art. $4^{\circ}$ ), apenas impedindo a formalização das parcerias entre a Administração Pública e a iniciativa privada sem fins lucrativos por meio de convênios, que ficarão restritos às relações de cooperação interfederativa prevista no art. 241 da Constituição Federal (art. 84).

${ }^{25}$ O Decreto Federal $n^{\circ}$ 6.170/2007 diferencia os convênios em sentido estrito dos contratos de repasse, fixando como única diferença o fato do segundo reclamar a intermediação de instituição ou agente financeiro público federal, que atuará como mandatário da União (art. $1^{\circ}, \S 1^{\circ}$, II). Via de regra, caberá à Administração Pública Federal escolher qualquer um desses instrumentos de parceria, sendo obrigatório o contrato de repasse somente no caso da execução do plano de trabalho envolver a realização de obra, muito embora se admita o convênio nesses casos se o órgão ou entidade administrativa possuir estrutura para acompanhar a sua execução (art. $8^{\circ}$ ). Explica Janaina SCHOENMAKER (2011:62) que duas são as etapas necessárias à celebração dos contratos de repasse: primeiro, a União assina contrato de cooperação com a instituição financeira pública, fixando-se os parâmetros do mandato outorgado; segundo, a instituição financeira, habilitada a atuar como mandatária da União, celebrará o contrato de repasse com entidades beneficiárias de transferências voluntárias. Ainda segundo a Autora, a Caixa Econômica Federal tem sido a instituição financeira intermediária entre o órgão repassador dos recursos e a organização privada, tendo por função acompanhar de perto a execução dos serviços prestados por estas.

${ }^{26}$ Vide o Boletim Gerencial de Transferências Voluntárias da União disponível no Portal dos Convênios do Governo Federal. Para Carolina Caiado LIMA (2010, p. 99), talvez a maior utilização dos convênios administrativos colaborativos decorra do fato de existirem em nosso ordenamento jurídico há mais tempo, já fazendo parte da rotina da Administração Brasileira. 
sem fins lucrativos, vindo disciplinado, no âmbito federal, na Lei Federal $n^{\circ}$ 8.666/1993, Leis de Diretrizes Orçamentárias, Decreto Federal n ${ }^{\circ}$ 6.170/200727, Portaria Interministerial MP/MG/CGU no 507/2011 e Instrução Normativa STN nº 01/199728.

Sem embargo, Maria Sylvia Zanella DI PIETRO (2015, p. 298) adverte que, por força do art. 84 da Lei Federal n ${ }^{\circ}$ 13.019/2014, o convênio e demais instrumentos similares deixaram de existir em nosso ordenamento jurídico enquanto instrumento de parceria entre o setor público e o privado por força do art. 84 da Lei 13.019/2014 ${ }^{29}$, remanescendo apenas para a formalização da cooperação interfederativa prevista no art. 241 da Constituição Federal $^{30}$. A Professora ressalva, contudo, os convênios colaborativos firmados no setor de saúde, mercê da sua previsão constitucional (art. 199, § $1^{\circ}$ ), não havendo como essa norma ser afastada pela previsão infraconstitucional da Lei Federal $n^{\circ}$ 13.019/2014. Importa registrar, outrossim, que o dispositivo legal em tela excepciona expressamente os contratos de gestão com as OSs e os termos de parceria com as OSCIPs, que ainda podem ser celebrados pela Administração Pública para fomentar atividades sociais em território brasileiro, não se falando em revogação da sua legislação de regência.

Os contratos de gestão, por sua vez, espécie de contrato de colaboração engendrado sob a lógica da já referida Reforma Administrativa, é instrumento de parceria celebrado entre o Estado e as chamadas organizações sociais, pessoas jurídicas não estatais criadas sob a forma de associação ou fundação e que recebem uma qualificação especial do Governo

\footnotetext{
${ }^{27}$ Este Decreto dispõe sobre "as normas relativas às transferências de recursos da União mediante convênios e contratos de repasse, e dá outras providências", tendo sido objeto de sucessivas alterações, sendo a mais profunda promovida pelo Decreto Federal $n^{\circ} 7.568 / 2011$ e a última pelo Decreto Federal no 8.244/2014.

${ }^{28}$ Esta Portaria regula "os convênios, os contratos de repasse e os termos de cooperação celebrados pelos órgãos e entidades da Administração Pública Federal com órgãos ou entidades públicas ou privadas sem fins lucrativos para a execução de programas, projetos e atividades de interesse recíproco, que envolvam a transferência de recursos financeiros oriundos do Orçamento Fiscal e da Seguridade Social da União", tendo sofrido diversas alterações, sendo a última feita pela Instrução Normativa STN n ${ }^{\circ}$ 01/2008. Também traz normas regulamentares do termo de parceria com as OSCIPs.

29 “Art. 84. Salvo nos casos expressamente previstos, não se aplica às relações de fomento e de colaboração regidas por esta Lei o disposto na Lei $\mathrm{n}^{\circ}$ 8.666, de 21 de junho de 1993, e na legislação referente a convênios, que ficarão restritos a parcerias firmadas entre os entes federados".

${ }^{30} \mathrm{Na}$ verdade, nos termos do par. único do art. 84 da novel Lei Federal n ${ }^{\circ}$ 13.019/2014, os convênios e instrumentos congêneres de colaboração com entidades da sociedade civil sem fins lucrativos vigentes à época da entrada em vigor da Lei serão executados até o término de seu prazo de vigência, continuando sujeitos à legislação específica dos convênios. Destaque-se, contudo, que o $\S 1^{\circ}$ do art. 83 da Lei de Parceria estabelece que, nas prorrogações dos ajustes firmados na vigência da lei anterior, passam a ser aplicadas as suas disposições, exceto no caso de prorrogação de ofício prevista em lei ou regulamento e desde que seja feita na hipótese de atraso na liberação de recursos por parte da Administração. $\mathrm{O} \S 2^{\circ}$ deste mesmo art. define ainda que, nas parcerias firmadas por prazo indeterminado antes da promulgação da Lei Federal no 13.019/2014, a Administração promoverá, no prazo não superior de um ano, sob pena de responsabilização, a repactuação para adaptação de seus termos à nova lei ou a respectiva rescisão
} 
Federal mediante a manifestação de interesse da entidade e o preenchimento dos requisitos contidos na Lei Federal no 9.637/1998 ${ }^{31}$.

De acordo com Fernando Dias MENEZES DE ALMEIDA (2012, p. 249), o contrato de gestão possui a mesma essência dos convênios em geral: conjunção de esforços de distintas pessoas para a consecução dum fim comum, no caso duma atividade não exclusiva do Estado que ele quer ver desempenhada e que também se faz presente no objeto social duma entidade privada sem fins lucrativos (associação ou fundação).

A outorga do título de OS e a celebração do contrato de gestão com as entidades assim qualificadas foram disciplinadas na Lei Federal n 9.637/1998 - Lei das OSs, que trouxe o controverso Programa Nacional de Publicização ${ }^{32}$, extinguiu duas estruturas administrativas federais (Laboratório Nacional de Luz Síncrotron e Fundação Roquette Pinto) e determinou a sua absorção por associações privadas específicas designadas no seu Anexo I, e autorizou a transferência de recursos orçamentários e a cessão de bens públicos e de servidores (com dispensa de licitação) no bojo do contrato de gestão.

Registre-se que o objeto do contrato de gestão é mais restrito do que aquele admitido aos convênios, na medida em que a Lei limita a outorga do título de OS e a possibilidade de celebração desse instrumento de parceria às entidades sem fins lucrativos

\footnotetext{
${ }^{31}$ Paulo Eduardo Garrido MODESTO (2006, p. 07-08) esclarece que a sua qualificação/titulação não implica a criação de nova forma de pessoa jurídica, tratando-se de entidades constituídas pelos particulares sob as formas comuns (já conhecidas) do Direito Civil (associações ou fundações) que voluntariamente recebem uma qualificação especial do Poder Público em virtude do atendimento de requisitos gerais de constituição e funcionamento previstos expressamente em lei, passando-se a se sujeitar a disposições jurídicas especiais, que lhes asseguram vantagens e sujeições incomuns. Segundo o Autor, "dá-se um plus à personalidade jurídica das entidades privadas, que passam a gozar de benefícios especiais não extensíveis às demais pessoas jurídicas privadas (benefícios tributários e vantagens administrativas diversas)". Em conclusão, declara que "Ser organização social não se pode traduzir em uma qualidade inata, mas em uma qualidade adquirida, resultado de um ato formal de reconhecimento do Poder Público, facultativo e eventual [...]”.

32 Programa Nacional de Publicização foi concebido pelo Plano Diretor da Reforma para a transformação de órgãos e entidades administrativas em organizações sociais, vindo previsto no art. 20 da Lei Federal $n^{\circ}$ 9.637/1998, a ser criado por meio de decreto federal sob as seguintes diretrizes: ênfase no atendimento do cidadão-cliente; ênfase nos resultados, qualitativos e quantitativos nos prazos pactuados; e controle social das ações de forma transparente. De acordo com Fernando Dias MENEZES DE ALMEIDA (2012, p. 249), a palavra publicização vem empregada no sentido de mitigação do aspecto privado da atuação administrativa a ser contratada pelo Estado. Gustavo Justino de OLIVEIRA (2008a, p. 17) explica que, "no contexto da reforma do aparelho do Estado, a concepção das organizações sociais legitimaria, de um lado, a extinção de órgãos e entidades públicas que estivesses levando a cabo atividades elencadas no art. $1^{\circ}$ da Lei Federal no 9.637/98, sendo que tais entidades seriam recriadas, porém constituídas de vínculos orgânicos com a Administração Pública de origem". Ressalvamos, contudo, que as OSs não devem necessariamente absorver órgãos e entidades administrativas, como se a qualificação e celebração do contrato de gestão estivessem condicionadas à redução/extinção de estruturas administrativas. A constitucionalidade da Lei Federal das OSs está sendo questionada no Supremo Tribunal Federal através da ADI n ${ }^{\circ}$ 1.923/DF, tendo sido indeferida a medida cautelar pedida, mas ainda pendente de julgamento no que diz respeito ao mérito. Na verdade, dois votos já foram proferidos, divergindo justamente quanto ao Programa Nacional de Publicização, numa discussão que permeia os limites da transferência da execução de atividades sociais do Estado para a iniciativa privada.
} 
"cujas atividades sejam dirigidas ao ensino, à pesquisa científica, ao desenvolvimento tecnológico, à proteção e preservação do meio ambiente, à cultura e à saúde", não contemplando, pois, toda e qualquer atividade social.

A seu turno, os termos de parceria são aqueles contratos de colaboração celebrados com a entidades da sociedade civil sem fins lucrativos qualificadas como OSCIPs ${ }^{33}$. Foram instituídos pela Lei Federal n ${ }^{\circ}$ 9.790/1999, estando, hoje, submetidos à disciplina subsidiária da Lei Federal n 13.019/2014 (art. 4º), além da regulamentação dada pelo Decreto Federal $n^{\circ} 3.100 / 1999$ e pela Portaria Interministerial MP/MF/CGU no 507/2011.

Sem prejuízo das diferenças existentes entre o modelo das OSCIPs e aquele das $\mathrm{OSs}^{34}$, Paulo Eduardo Garrido MODESTO (2006, p. 11-12) destaca as semelhanças dessas espécies de contrato de colaboração, eis que tanto o contrato de gestão quanto o termo de parceria são instrumentos de parceria social entre o setor público e o privado dependentes da pré-qualificação da organização da sociedade civil ${ }^{35}$.

\footnotetext{
${ }^{33}$ Conforme esclarece Gustavo Justino de OLIVEIRA (2007c, p. 218), “A OSCIP é uma qualificação especial, concedida pelo Ministro da Justiça àquelas entidades da sociedade civil sem fins lucrativos que, além de cumprirem determinados requisitos legalmente exigidos, tenham por finalidade social uma das atividades enumeradas na Lei federal n 9.790/99".

${ }^{34}$ De acordo com o Autor (2006, p. 12-15), a Lei das OSCIPs inova ao: prever genericamente candidatos negativos (art. $2^{\circ}$ ); especificar detalhadamente os "candidatos positivos", a exemplo da exigência de que os serviços de saúde e de educação deverão ser integralmente gratuitos ( $\operatorname{art.} 3^{\circ}$ ); exigir a adoção dos procedimentos contábeis definidos pelas Normas Brasileiras de Contabilidade (art. 4", VII, “a”); indiretamente exigir prazo mínimo de pré-existência da entidade de um exercício financeiro (art. 5’, II e IV) - hoje diretamente estabelecida no art. $9^{\circ}$, III, do Decreto Federal n ${ }^{\circ} 3.100 / 1999$-; fixar do prazo de trinta dias para a análise do pedido de qualificação da entidade pelo Ministro da Justiça; proibir expressamente a participação das entidades qualificadas em campanhas de caráter político-partidário ou eleitorais (art. 16); e admitir expressamente a cumulação (temporária) do título de OSCIP com outros certificados aplicados a pessoas de direito privado sem fins lucrativos (art. 18). Ele conclui que a Lei Federal $n^{\circ}$ 9.790/1999 corrige deficiências encontradas nos títulos de utilidade pública e de organização social, com visível fortalecimento dos mecanismos de controle social sobre as entidades do terceiro setor (arts. $7^{\circ}, 10, \S 1^{\circ}$, e 11). Acrescente-se, ainda, dentre outras diferenças, o caráter vinculado da decisão de atribuição da qualificação de OSCIP, que não ocorre com aquele de OS, ao menos diante da redação do art. $2^{\circ}$, II, da Lei Federal n ${ }^{\circ}$ 9.637/1998; e a não autorização da cessão de bens públicos e servidores com ônus para a origem enquanto mecanismo de fomento admitido aos termos de parceria.

35 Maria Sylvia Zanella DI PIETRO (2015, p. 290) também reconhece alguma semelhança entre as OSCIPs e as OSs, uma vez que "ambas são entidades privadas, sem fins lucrativos, que, uma vez preenchidos os requisitos legais, recebem uma qualificação do Poder Público". Para a Autora, contudo, elas se distinguiriam de forma essencial quanto à natureza das atividades por ela desenvolvidas: as OSs receberiam ou poderiam receber a gestão de serviço público, ao passo que as OSCIPs exerceriam atividade de natureza privada [diferente de serviço público] com a ajuda do Poder Público, tratando-se de legítima forma de fomento estatal. Pedimos vênia para não ingressar nessa discussão por ora, a qual será esmiuçada em momento posterior nessa dissertação.
} 
Finalmente, existem o termo de fomento e o termo de colaboração, criados pela novel Lei Federal $n^{\circ}$ 13.019/2014 - aqui chamada de Lei de Parcerias Sociais entre os Setores Público e Privado ou simplesmente Lei de Parcerias Sociais ${ }^{36}$.

Esse diploma normativo pretende uniformizar e aglutinar a disciplina dos contratos de colaboração, na medida em que: impõe a instrumentalização das parcerias sociais entre o setor público e o setor privado através dos tais termos de fomento e de colaboração, apenas ressalvando os contratos de gestão com as OSs e os termos de parceria com as OSCIPs (art. 41, caput e par. único), que continuarão a poder ser celebrados pela Administração Federal $^{3738}$; afasta expressamente a aplicação de legislações outras aos contratos de colaboração, a exemplo da Lei Federal nº 8.666/1993 e dos diplomas normativos que tratam dos convênios, estes que, como já anunciado, ficarão restritos à cooperação interfederativa (art. 84), visando a acabar com a concorrência de legislações distintas e substancialmente desconformes; e disciplina aspectos essenciais da celebração, execução e extinção dos contratos de colaboração, diminuindo a margem de liberdade do poder regulamentar da Administração Pública.

Maria Sylvia Zanella DI PIETRO (2015, p. 296) observa que, ao contrário dos demais instrumentos de parceria apresentados, a Lei Federal nº 13.019/2014 não está restrita ao âmbito federal, tratando-se, conforme estabelece o seu art. $1^{\circ}$, de lei de caráter nacional, aplicável às Administrações Públicas Diretas e Indiretas das três esferas de governo. De acordo com a Autora, o novel diploma traz normas gerais elaboradas com fundamento na

\footnotetext{
${ }^{36} \mathrm{O}$ qualificativo generalizante se justifica na medida em que, ao contrário das leis que tratam das OSCIPs e das OSs, a Lei Federal $\mathrm{n}^{\circ}$ 13.019/2014 pretende regular as "parcerias voluntárias, envolvendo ou não transferências de recursos financeiros, entre a administração pública e as organizações da sociedade civil, em regime de mútua cooperação, para a consecução de finalidades de interesse público", envolvendo, portanto, toda e qualquer atividade social, de relevância pública (epígrafe c/c art. 33, I). Nada obstante, registre-se que Maria Sylvia Zanella DI PIETRO (2015, p. 296-312) refere-se a esse recente diploma normativo simplesmente como Lei de Parcerias.

${ }^{37}$ Mais uma vez, pertinentes são as críticas feitas por Rodrigo Pagani de SOUZA (2009, p. 312) a respeito da concorrência dessas espécies de contratos de colaboração em nosso ordenamento jurídico, as quais, a despeito de se prestarem à mesma finalidade de cooperação entre os setores público e privado nos serviços sociais, sujeitam-se a regimes jurídicos distintos, gerando uma complexidade desnecessária em nosso Direito Positivo, com prejuízos à segurança jurídica. Como se percebe, a recente Lei Federal no 13.019/2014 não solucionou o problema, vindo até mesmo a contribuir para essa confusão legislativa, eis que determina a sua aplicação subsidiária a espécies colaborativas outras sujeitas a uma legislação própria, a exemplo do que faz com o termo de parceria com as OSCIPs (art. $4^{\circ}$ ) e com instrumentos de parcerias outros [salvo o contrato de gestão com as OSs] firmados antes da sua entrada em vigor (art. 83).

${ }^{38}$ Como já advertido, a Lei permite que outras modalidades de parceria que tenham sido firmadas antes da sua entrada em vigor continuem valendo e fiquem sob a regência da sua legislação própria, sem prejuízo da aplicação subsidiária da Lei de Parcerias Sociais (art. 83).
} 
competência constitucional privativa da União para legislar sobre licitação e contratação (art. 22, XXVII).

Sem prejuízo da juridicidade da expressão contratos de colaboração, registre-se a existência de autores que dela se utilizam num sentido totalmente diverso daquele defendido na presente dissertação. É o caso de Marçal JUSTEN FILHO (2013, p. 476 e 480-481), para quem eles seriam espécie de contratos administrativos em sentido restrito ${ }^{39}$, os quais se subdividem em contratos de colaboração e contratos de delegação de competência: os primeiros seriam entendidos como os ajustes firmados pelo Poder Público "para constituir relação jurídica destinada ou satisfazer de modo direto necessidades da Administração Pública", tendo por objeto compras, serviços, obras ou alienações, não conferindo ao particular poderes e competências próprias da Administração Pública; e os segundos envolveriam "a atribuição a um particular da prestação de um serviço público", delegandolhe um título para que desempenhe funções tipicamente estatais.

Percebe-se que a visão do Autor insere os contratos de colaboração na teorização de contrato administrativo desenvolvida no início do século XX pelo Conselho de Estado Francês, que rompeu com os princípios da igualdade entre as partes e da intangibilidade da vontade inicial, encarando os ajustes negociais firmados pela Administração Pública e os particulares num contexto de restrições/vinculações e prerrogativas/poderes extroversos, a exemplo dos contratos de obras, de serviços, de compra e de concessão ${ }^{40}$. A ideia do Autor

\footnotetext{
${ }^{39}$ Para o Autor (2013, p. 476; 586-587), os contratos administrativos em sentido amplo - cujo conceito legal estaria no par. único do art. $2^{\circ}$ da Lei 8.666/1993 - seriam “o acordo de vontades destinado a criar, modificar ou extinguir direitos e obrigações, tal como facultado legislativamente e em que pelo menos uma das partes atua no exercício da função administrativa". Tratar-se-ia de gênero, no qual se incluiriam: (i) os acordos de vontade da Administração - não destinados a satisfazer, de modo direto e imediato, uma necessidade do aparato administrativo e dos membros da comunidade, eles funcionariam como "instrumentos regulatórios para ordenação de condutas necessárias à produção de efeitos relevantes para a comunidade", a exemplo dos convênios públicos, contrato de gestão, termo de parceria, consórcios públicos, contratos de fomento e termos de ajustamento de conduta; (ii) os contratos administrativos em sentido restrito - firmados "para constituir relação jurídica destinada ou satisfazer de modo direto necessidades da Administração Pública ou a constituir uma delegação a um particular da prestação de serviço público", subdividindo-se, quanto ao regime jurídico, em contratos de colaboração e contratos de delegação de competência; e os (iii) contratos de direito privado - sujeitos, em sua essência, ao regime de direito privado, assim se classificando não em função da natureza ou do objeto do contrato, mas do setor a que a contratação se relaciona, que impede a aplicação em massa do regime de direito público, de modo a se evitar a supressão do regime de mercado e o desequilíbrio que inviabilizaria a empresa privada, não importando o contrato isoladamente considerado, mas as atividades e empresas que praticam essa contratação. Percebe-se, enfim, que a nossa noção de contrato de colaboração estaria incluída na primeira espécie de contratos administrativos lato sensu, qual seja no de acordo de vontade da Administração, em nada se confundindo com a concepção do Autor.

40 Odete MEDAUAR (2013, p. 241-243) trabalha a evolução da noção de contrato administrativo: (i) Concepção Clássica (Grécia Clássica e Direito Romano mais antigo): contrato enquanto intercâmbio de bens e prestações regido pelo Direito; (ii) Concepção Moderna (séculos XVIII e IXX): contrato enquanto acordo de vontades entre particulares destinado a produzir efeitos jurídicos, fundado na autonomia da vontade, igualdade entre as partes e imutabilidade da vontade inicial (a Administração não poderia celebrar contratos em razão da
} 
faz correspondência justamente àqueles contratos disciplinados pela Lei Federal $\mathrm{n}^{\mathrm{o}}$ $8.666 / 1993$.

Como se percebe, a noção de contrato de colaboração aqui defendida não se confunde com aquela dos tradicionais contratos administrativos, regidos que são pela Lei Federal no 8.666/1993 e destinados à aquisição de bens e serviços junto ao mercado pela Administração Pública ou à alienação de bens públicos, celebrados sob a lógica retributiva/remuneratória, com garantia do equilíbrio econômico-financeiro. Diferentemente, os contratos de colaboração são instrumento da associação negociada de entidades estatais e organizações da sociedade civil sem fins lucrativos para a prestação de serviços sociais à coletividade, não estando as prestações [de fomento] do Estado referenciadas por aquelas do parceiro privado ${ }^{41}$, ainda que exista uma relação contraprestacional entre elas, na medida em que se condiciona a entrega da contribuição estatal à execução dos compromissos da entidade privada de colaboração.

Ademais, é fundamental distinguir os contratos de colaboração dos instrumentos de delegação estatal de serviços públicos (concessão e permissão): nos contratos de colaboração, os particulares exercem atividades de marcado interesse público por direito próprio, independentemente de qualquer ato formal de delegação estatal, tratando-se de zona

sua posição de supremacia em relação ao particular, manifestando-se por atos administrativos); (iii) Teoria (Clássica) dos Contratos Administrativos (final do século IXX e XX): contrato administrativo enquanto contrato diferenciado do modelo privado, em que a Administração Pública dispõe de certas prerrogativas, afastando-se de alguns preceitos da teoria do contrato privado vigente desde o século XVIII, como a igualdade entre as partes e a intangibilidade da vontade inicial; (iv) Consenso, acordo, cooperação ou parceria entre a Administração e particulares ou entre órgãos e entidades públicas (a partir dos anos 70 do século XX): considerados contrato em razão do resgate da concepção clássica de "intercâmbio de bens e prestações regido pelo Direito", donde resulta que tanto os contratos privados e os contratos administrativos quanto essas figuras convencionais se inserem num mesmo "módulo contratual".

${ }^{41}$ Não se olvida, contudo, a chamada função promocional dos tradicionais contratos administrativos, os quais também servem, de forma indireta ou mediata, à produção de benefícios sociais. Reconhecendo essa realidade, Marçal JUSTEN FILHO e Eduardo FERREIRA JORDÃO (2013, p. VI-1) observam que a Lei 12.349/2010 alterou o art. $3^{\circ}$ da Lei 8.666/93 para explicitar que a licitação se norteia não apenas para selecionar a proposta mais vantajosa para a Administração Pública, mas também para promover "o desenvolvimento nacional sustentável", destacando-se o uso das contratações administrativas para a implantação de políticas públicas. Ainda de acordo com os Autores (2013, p. VI-2), existe também a possibilidade da chamada "regulação por contrato", em que a intervenção regulatória se revela em disposições acessórias à contratação, como a imposição de especificações relativas ao uso de determinadas matérias-primas ou ao emprego de determinadas minorias. Para eles, conquanto não totalmente proscrita no nosso Direito, essa regulação por contrato encontra, no Brasil, limites no art. $3^{\circ}, \S 1^{\circ}$, I, da Lei 8.666/93. A função regulatória da licitação também é destaque do voto do Ministro Luiz FUX no julgamento do mérito da ADI ${ }^{\circ} 1.923 / \mathrm{DF}$, quando o autor entendeu que a dispensa de licitação contida no art. 24, XXI, da Lei Federal no 8.666/1993 (para a contratação dos serviços prestados por organizações sociais e contemplados no respectivo contrato de gestão celebrado) não seria inconstitucional exatamente por se tratar de mecanismo de indução de práticas sociais benéficas através do fomento da atuação das organizações sociais, ressalvando-se, contudo, a necessidade dessa hipótese de dispensa de licitação observar os princípios constitucionais da impessoalidade, moralidade, publicidade, legalidade e impessoalidade. 
livre à iniciativa privada, que voluntariamente se associa ao Poder Público visando a obter incentivos e melhor desenvolver os seus objetivos sociais; nos contratos de delegação de serviços públicos, diferentemente, está em jogo uma atividade sujeita a monopólio ou privilégio estatal, interditada à prestação pelas entidades da sociedade civil, que, conforme prescrito no art. 175 da Constituição, somente podem ingressar nesses setores através de delegação pública, fazendo as vezes do $E \operatorname{stado}^{42}$, com sujeições e prerrogativas exorbitantes.

Paulo Eduardo Garrido MODESTO (2011, p. 07) é preciso ao divisar as relações de parceria daquelas de delegação, afirmando que as entidades privadas parceiras do Estado, embora se sujeitem a deveres públicos por "manejarem recursos de fomento do Estado vinculados a atividades socialmente relevantes", não integram o aparato do Estado nem exercitam prerrogativas públicas, razão pela qual não é de se aceitar que o Direito Público abranja essas relações colaborativas nos serviços sociais da mesma forma que incide sobre o Estado e seus delegados no exercício de função pública. Conclui o Autor ser é absolutamente indevida a publicização estrita das relações de parceria social travadas entre as entidades privadas sem fins lucrativos e a Administração.

O contrato de colaboração não se confunde, ainda, com a terceirização de serviços levada a cabo pelo Estado ${ }^{43}$, na qual a Administração Pública ostenta a posição de tomadora dos serviços, sendo ela a usuária direta das atividades contratadas. Diferentemente, no contrato de colaboração, o serviço [social] é prestado por organizações da sociedade civil sem fins lucrativos em benefício da coletividade, funcionando a Administração como mera

\footnotetext{
${ }^{42}$ A natureza do objeto dos contratos de colaboração será examinada em capítulo próprio no presente trabalho, no qual se demonstrará se tratar de serviços de relevância pública e ao qual remetemos o leitor.

${ }^{43}$ Maria Sylvia Zanella DI PIETRO (2015, p. 223-225) leciona que a terceirização tem por objeto a prestação de serviços, à semelhança do que ocorre com o contrato de empreitada, em que o contratante quer o resultado, sendo irrelevante a identidade dos agentes que desempenham a atividade, dado que o fim do ajuste se limita à obtenção do resultado material pactuado. Para ela, a terceirização difere da contratação de trabalhador por intermediação de empresa de prestação de serviços a terceiros, na medida em que apenas nesta existe pessoalidade na relação com os agentes, assumindo o contrato respectivo a forma de fornecimento de mão de obra, inaceitável em nosso sistema jurídico por violar a regra constitucional do concurso público (art. 37, IX) - na terceirização, repita-se, quem presta os serviços é a empresa contratada, sem qualquer pessoalidade entre a tomadora e o trabalhador. Para a Autora, é lícita a terceirização na Administração Pública, desde que assuma a forma de contrato de empreitada, seja para a realização de obra pública - conforme definida no art. $6^{\circ}, \mathrm{I}$, da Lei no 8.666/93 -, seja para a prestação de serviço - tal como conceituado nos arts. $6^{\circ}$, II, e 13 desta mesma lei. Observa, ainda, que a terceirização - enquanto contrato de prestação de serviços - somente seria lícita quando, na esteira das Súmulas 256 e 331 do Tribunal Superior do Trabalho, c/c a decisão do STF na ADC n ${ }^{\circ}$ 16/DF, restringir-se às atividades-meio da tomadora dos serviços. Sérgio Pinto MARTINS (2007, p. 24) ensina que "A terceirização é um contrato triangular, em que há o trabalhador, a empresa que presta serviços e a tomadora de serviços". Para ele, contudo, terceirização não se confundiria com a empreitada (locatio operis), vez que, nesta o que interessa é o resultado da obra (a construção dum muro, a pintura duma parede, etc.), não havendo um sistema de parceria entre quem contrata a empreitada e o empreiteiro, este que tem interesse em concluir a obra, e não em ser parceiro do terceirizante. Na terceirização, diferentemente, a ideia de parceria seria substancial.
} 
incentivadora da iniciativa privada de interesse público, não remunerando propriamente as atividades desenvolvidas, mas apenas disponibilizando ao parceiro privado vantagens a título de fomento público, as quais sequer necessitam ser de natureza econômicofinanceira ${ }^{44}$.

Da noção de contrato de colaboração proposta no presente trabalho, enfim, identificamos se tratar de (i) acordo de vontades de caráter continuado celebrado entre (ii) entidades estatais e a iniciativa privada sem fins lucrativos para a (iii) prestação colaborada de (iv) serviços sociais em benefício da coletividade. Esses quatro elementos serão explorados nos capítulos seguintes, com o objetivo de, a partir da identificação da natureza jurídica de cada um deles, revelar as suas implicações para regime jurídico das parcerias sociais entre os setores público e privado.

${ }^{44} \mathrm{O}$ fomento e seus meios de expressão serão examinados no Capítulo 2.2 desta Parte I. Destaque-se que o art. 40, II, da Lei Federal n ${ }^{\circ}$ 13.019/2014 veda expressamente a celebração de termos de colaboração ou de fomento que tenham por objeto "a prestação de serviços ou de atividades cujo destinatário seja o aparelho administrativo do Estado". 


\section{DA NATUREZA JURÍDICA DO INSTRUMENTO}

\subsection{Da Natureza de Contrato}

A definição do regime jurídico dos contratos de colaboração pressupõe a identificação da natureza jurídica dos instrumentos de que se utiliza o Poder Público para firmar parcerias sociais com o setor privado, determinante que é, conforme veremos, para a definição da competência constitucional legislativa sobre a matéria e, por consequência, o universo de normas incidentes.

Inseridos os contratos de colaboração na noção ampla de convênios administrativos, interessa-nos perquirir a natureza jurídica desses ajustes colaborativos, questão deveras controvertida na doutrina brasileira, identificando-se, com bem faz LIMA (2010, p. 37-48), pelo menos 03 (três) correntes sobre o tema: (i) acordo de vontades: (ii) contrato administrativo; e (iii) ato administrativo complexo.

A primeira linha de pensamento que coloca as parcerias sociais entre os setores público e privado como meros acordos de vontade corresponde à visão mais tradicional dos convênios administrativos, desenvolvida em nosso país, conforme já exposto, por Hely Lopes MEIRELLES (2002, p. 383), fundamentando-se basicamente na suposta ausência de interesses contrapostos ${ }^{45}$ e de reciprocidade de obrigações entre os partícipes ou convenentes. Na doutrina brasileira, é seguida, verbi gratia, por Edmir Netto de ARAÚJO (2012, p. 728), José dos Santos CARVALHO FILHO (2013, p. 224-228) e Maria Sylvia Zanella DI PIETRO (2015, p. 238-239)

Filiando-se a essa corrente, Maria Nazaré Lins BARBOSA (2011, p. 535) sintetiza as seguintes características do convênio, que o diferenciariam do contrato: os interesses são recíprocos, e não contrapostos; os entes conveniados têm objetivos institucionais (competências institucionais) comuns, reunindo-se para alcançá-los; por almejarem o mesmo objetivo, os seus signatários não são rigorosamente partes, não cobrando taxa ou remuneração entre si; o valor eventualmente entregue por um dos convenentes ao outro

\footnotetext{
45 Seguindo os ensinamentos de Hely Lopes MEIRELLES, José Eduardo Sabo PAES (2013, p. 802-803) considera que o único ponto comum entre o contrato e o convênio é a existência do acordo de vontades, não se confundindo essas duas espécies de ajustes porque, no primeiro, os interesses das partes são divergentes e opostos, enquanto que, no segundo, eles são coincidentes e comuns, havendo um evento de interesse recíproco executado em regime de mútua cooperação.
} 
somente pode ser utilizado para os fins previstos no instrumento, não se tratando de remuneração, que passa a integrar o patrimônio da entidade que a recebeu, sendo irrelevante para o repassador a utilização que será feita do mesmo ${ }^{46}$.

É Hely Lopes MEIRELLES (2002, p. 383) ainda quem acrescenta como características diferenciadoras dos convênios em relação aos contratos a instabilidade e precariedade daqueles ajustes colaborativos, permitindo que qualquer partícipe o denuncie e retire sua cooperação quando o desejar, ficando responsável apenas pelas obrigações e auferindo as vantagens do tempo em que participou voluntariamente do acordo. Para ele, "a liberdade de ingresso e retirada dos partícipes do convênio é traço característico dessa cooperação associativa, e, por isso mesmo, não admite cláusula obrigatória da permanência ou sancionadora dos denunciantes"

Afigura-se interessante o raciocínio espacial e direcional construído por Edmir Netto de ARAÚJO (2012, p. 728), de acordo com o qual os "Convênios administrativos são convenções, mas não contratos, pois nestes as vontades são antagônicas, se compõem, mas não se adicionam, delas resultando uma terceira espécie (vontade contratual, resultante e não soma), ao passo que nos convênios, como nos consórcios, as vontades se somam, atuam paralelamente, para alcançar interesses e objetivos comuns" ${ }^{\text {"48 }}$. De forma peculiar, o Autor classifica os convênios administrativos em acordos de cooperação, quando todas as pessoas estão preordenadas para o fim desejado; e acordos de colaboração, quando um dos convenentes desempenha atividades-meio, preparatórias, auxiliares ou complementares do outro, para o objetivo comum.

\footnotetext{
${ }^{46}$ Neste particular, distinguindo convênio de contrato, Maria Sylvia Zanella DI PIETRO (2013, p. 348) entende que, "no contrato, o valor pago a título de remuneração passa a integrar o patrimônio da entidade que o recebeu, sendo irrelevante para o órgão repassador a utilização que será feita do mesmo", daí porque, ao revés, no convênio, se o conveniado recebe determinado valor, este fica vinculado à utilização prevista no ajuste e, tratando-se de verbas públicas, o convenente não estatal deverá prestar contas ao Tribunal de Contas.

${ }^{47}$ Esse é mesmo entendimento de Edmir Netto de ARAÚJO (2012, p. 728) e José dos Santos CARVALHO FILHO (2013, p. 225), este último para quem imperaria no convênio o princípio do informalismo, podendo o pactuante se retirar do ajuste (denúncia do convênio) a qualquer tempo sem suportar efeitos negativos de maior relevância e não sendo exigível o pressuposto da personalidade jurídica (ao contrário do que ocorre com o contrato). Neste ponto, registramos que, encampando a tradicional visão acerca dos convênios e instrumentos congêneres de cooperação mútua, o Decreto Federal nº 6.170/2008 veda a aposição de cláusula de permanência - como não poderia de ser, tendo em vista a garantia constitucional da liberdade de associação - ou sancionadora do denunciante, a despeito de prever que ficam os partícipes "responsáveis somente pelas obrigações e auferindo as vantagens do tempo em que participaram voluntariamente do acordo". De se perceber, ainda, que, no RE $n^{\circ} 119.256-9 / \mathrm{SP}$, o Supremo Tribunal Federal acolheu a tradicional distinção entre convênios e contratos e se manifestou pela precariedade desses ajustes colaborativos, negando aos seus beneficiários o direito à manutenção do vínculo, não se falando em direito adquirido

${ }^{48}$ Com o devido respeito, o raciocínio do Autor pouco contribui para a diferenciação, provocando incertezas quanto ao sentido de "compor-se mas não se adicionar" e de "somar-se e atuar paralelamente ao mesmo tempo".
} 
O Tribunal de Contas da União - TCU segue essa primeira linha de pensamento, tendo diferenciado expressamente convênio de contrato no Acórdão $\mathrm{n}^{\mathrm{o}}$ 1.077/2005, principalmente pela [suposta] ausência de reciprocidade de obrigações do primeiro, um vez que, no contrato, uma das partes se obriga a dar, fazer ou não fazer alguma coisa mediante pagamento previamente acertado, ao passo que, no convênio, os interesses são comuns e a contraprestação em dinheiro não precisa existir, tratando-se de ajuste de mútua colaboração para atingimento de objetivo comum.

Também o Supremo Tribunal Federal - STF já se manifestou por essa primeira corrente de pensamento, encampando expressamente a doutrina de Hely Lopes MEIRELLES no mencionado RE $\mathrm{n}^{\circ}$ 119.256-9/SP, chegando a afirmar a precariedade dos convênios, no qual não haveria direito adquirido dos seus partícipes à manutenção do vínculo 49 .

Anote-se que essa tradicional distinção entre convênio e contrato já constou textualmente do nosso ordenamento jurídico, nomeadamente no art. 48 do Decreto $\mathrm{n}^{\circ}$ 93.872/1986, que acabou sendo revogado pelo Decreto Federal no 6.170/2007 e assim dispunha:

\footnotetext{
Art. 48. Os serviços de interesse recíproco dos órgãos e entidades da administração federal e de outras entidades públicas ou organizações particulares, poderão ser executados sob regime de mútua cooperação, mediante convênio, acordo ou ajuste.

$\S 1^{\circ}$. Quando os participantes tenham interesses diversos e opostos, isto é, quando se desejar, de um lado, o objeto do acordo ou ajuste, e de outro lado a contraprestação correspondente, ou seja, o preço ou ajuste constitui contrato.
}

Um segundo entendimento - denominado atual por Janaina SCHOENMAKER (2011, p. 59) - inclui os convênios na noção de contrato, numa relação de gênero e espécie.

Filiando-se a essa segunda corrente de pensamento, Celso Antônio Bandeira de MELLO (2009, p. 657-660) afirma que o contrato, enquanto instituto da Teoria Geral do Direito, compreende duas modalidades básicas, a saber: contratos em que as partes se compõem para atender a interesses contrapostos; e contratos em que, inversamente, as partes se compõem pela comunidade de interesses.

${ }^{49}$ Recentemente adotada pelo Ministro Ayres Britto no julgamento do mérito da ADI $n^{\text {o }} 1.923 / \mathrm{DF}$, que consignou que o contrato de gestão com as OSs consiste, em linhas gerais, num convênio, e não exatamente num contrato de direito público, senão nominalmente, daí a sua conclusão de que, em princípio, haveria desnecessidade de processo licitatório. 
Essa também é a visão de Odete MEDAUAR (2013, p. 241-242), de acordo com a qual, assim como ocorreu com os contratos administrativos clássicos dos primórdios do século $\mathrm{XX}^{50}$, é possível incluir os instrumentos convencionais (decorrentes do consenso, acordo e cooperação) num módulo contratual, bastando para tanto que se deixe de lado a concepção restrita de contrato vigente no século XIX, centrada na autonomia da vontade, na igualdade absoluta entre as partes e na imutabilidade da vontade inicial, e se retome a ideia básica de contrato predominante na Grécia Clássica e no Direito Romano mais antigo, baseada no intercâmbio de bens e prestações, regido pelo Direito, com possibilidade de regimes jurídicos diversos ${ }^{51}$.

Da mesma forma, reconhecendo a insuficiência intrínseca da teoria [moderna] do contrato administrativo para explicar o complexo fenômeno contratual da Administração, Fernando Dias MENEZES DE ALMEIDA (2012, p. 242-246) defende a existência dum gênero contratual no qual se incluem os convênios lato sensu, falando em módulos convencionais ou contratuais em sentido amplo. Para ele, todos esses instrumentos convencionais de cooperação celebrados pela Administração criam situações jurídicas subjetivas [direitos e obrigações exigíveis juridicamente], na medida em que produzem regras aplicáveis individualmente às pessoas envolvidas, estabelecendo-se obrigações das partes em relação às atividades a serem realizadas, com metas e prazos de execução fixados.

Com precisão, Marçal JUSTEN FILHO (2005, p. 25-26) pontua não haver na Teoria Geral do Direito uma categoria de ato jurídico específica e autônoma denominada convênio, apontando como justificativa para a utilização desta expressão no Direito Administrativo Brasileiro a intenção de evitar confusões com as avenças tradicionalmente praticadas entre a Administração Pública e particulares, marcadas que são pela desigualdade, imperatividade e poderes extroversos. Para o Autor, os convênios são espécie de contrato plurilateral, avença caracterizada pela possibilidade de participação de mais de duas partes

\footnotetext{
${ }^{50}$ Quando acabou se firmando a noção francesa de contrato administrativo enquanto ajustes celebrados pela Administração Pública com particulares para a aquisição de obras, serviços e compras e realização de concessões e alienações públicas, marcados pela relativização do princípio da intangibilidade contratual e da igualdade formal dos contratantes, com prerrogativas e sujeições exorbitantes do Direito Comum (Civil).

${ }^{51}$ Odete MEDAUAR (1995, p. 75-81) demonstra situações em que os interesses convergentes são objeto de contrato e os interesses contrapostos se fazem presentes nos convênios; que o suposto exercício de competências comuns nos convênios não existe no caso de parcerias com os particulares; e que, ainda que não se fale em preço, o repasse de verbas num convênio tem sentido remuneratório.
} 
e pela inexistência de câmbio de riquezas entre os contratantes, objetivando a realização de certa atividade de interesse comum por meio da organização de bens e esforços ${ }^{52}$.

Também se alinhando pela natureza contratual dos convênios, Silvio Luís Ferreira da ROCHA (2006, p. 53-53) entende não haver diferença quanto à natureza, mas apenas de conteúdo, dado que inexistiria no convênio as chamadas cláusulas exorbitantes, tratando-se de verdadeiro contrato associativo.

Registre-se, ainda, as lições de Gustavo Alexandre MAGALHÃES (2012, p. ), de acordo com o qual "[...] os argumentos utilizados pela doutrina tradicional para negar natureza contratual aos convênios não resistem à análise dos contratos e dos convênios segundo a Teoria Geral do Negócio Jurídico, vez que o consenso (acordo de vontades) e a direção à produção de efeitos jurídicos (criação, modificação ou extinção de determinada relação jurídica) seriam os únicos requisitos inquestionáveis para a celebração do contrato, estando presentes também nos acordos colaborativos (convênios), que ostentariam a natureza de verdadeiros contratos bi/plurilaterais de natureza reflexiva ${ }^{53}$.

Finalmente, há o entendimento de que os convênios seriam atos administrativos complexos, doutrina bem defendida por Diogo de Figueiredo MOREIRA NETO (2014, p. 206-217), segundo o qual os atos administrativos complexos e os contratos administrativos seriam espécies do gênero pacto, entendido como todo e qualquer ato bilateral/multilateral celebrado pela Administração Pública. Anotando a sua origem alemã (na teorização de Otto GIERKE, aperfeiçoada pela diferenciação tedesca que se seguiu entre contrato e acordo e da sua aplicação à fenomenologia do Direito Administrativo pela doutrina jurídica italiana), ele conceitua o ato administrativo complexo como:

[...] o concurso de manifestações de vontade autônomas em que, conforme a espécie, uma delas, várias ou todas emanam da Administração Pública, tendo por objeto comum a constituição de uma relação jurídica de coordenação de vontades, tanto nas modalidades de cooperação com de colaboração, visando a um resultado

\footnotetext{
${ }^{52}$ Sem prejuízo, Marçal JUSTEN FILHO (2013, p. 473-473) afirma que o convênio não se confunde com as contratações administrativas em sentido restrito, tratando-se de contrato associativo/cooperativo/associativo, em que a prestação de uma das partes não se destina a ser incorporada no patrimônio da outra, inexistindo, portanto, o caráter comutativo, não se falando em transferência entre si da titularidade de bens e serviços.

${ }^{53}$ Referindo-se à ampla doutrina civilista, em especial aos ensinamentos de Pontes de MIRANDA, Gustavo Alexandre MAGALHÃES (2012, p. 175) desconstrói a exigência de contraposição de interesses no contrato, demonstrando que aquilo que exige nos negócios jurídicos bilaterais (contratos) é a enantiomorfia dos interesses, vale dizer, se tratar de interesses distintos e complementares, convergentes para um negócio jurídico. Para o Autor, "Trata-se da complementaridade dos distintos interesses representados em um negócio bilateral. Tanto no contrato quanto no convênio existem interesses distintos (sob pena de se ter uma única parte no negócio), que se complementam no intuito de atingir o objeto da avença".
} 
de interesse público comum às partes acordantes e de competência, pelo menos, de uma delas.

Nessa linha, o Autor (2014, p. 207) explica que os atos administrativos complexos não se confundiriam com os contratos administrativos por duas razões: (i) quanto às vontades, que, no contrato, se comporiam, resultando uma terceira vontade, ao passo que, no ato complexo, elas se acresceriam uma à outra, atuando autônoma e paralelamente ${ }^{54}$; e (ii) quanto aos interesses, que, no contrato, seriam distintos e opostos, enquanto que, no ato complexo, seriam comuns e convergentes, daí a designação também corrente de ato-união.

Ainda segundo Diogo de Figueiredo MOREIRA NETO (2014, p. 208), os atos administrativos complexos compõem gênero aberto, no qual se incluem as espécies tradicionais do convênio [em sentido próprio] e do consórcio público, assim como as mais recentes figuras do acordo de programa, ajustamento de conduta, conferência de serviços, acordo substitutivo, protocolo de intenção, concertos administrativos e tantas outras figuras recolhidas na literatura jurídica dos acordos não contratuais.

Percebe-se que essa terceira corrente doutrinária aproveita-se dos ensinamentos contidos naqueloutra inaugurada por Hely Lopes MEIRELLES, afirmando se tratar de acordo ou coordenação de vontades, mas apenas trazendo essas noções para o âmbito do Direito Administrativo (mais especificamente para a teoria do ato administrativo), destacando a vontade e a competência da Administração Pública na celebração desses pactos colaborativos.

Servindo-nos aqui da referida ideia de que o contrato é figura pertencente ao Direito como um todo e um instrumento disciplinador de prestações e bens voltados à realização dos interesses divergentes e convergentes das partes envolvidas (caráter reflexivo do negócio jurídico bilateral), filiamo-nos à segunda corrente e colocamos todas essas parcerias sociais entre o setor público e o setor privado (convênio propriamente dito, contrato de gestão, termo de parceria, termo de colaboração, termo de fomento, acordos em geral) como espécies de contrato administrativo lato sensu ${ }^{55}$.

\footnotetext{
${ }^{54}$ O Autor (2014, p. 209) observa que, no contrato, o consenso atua sob a forma de composição de vontades, partindo originalmente de visões antagônicas, com vistas a interesses distintos, para compor a vontade ficta contratual, enquanto que, no ato complexo, ele atua como elemento de "conjugação de vontades", que se mantêm paralelas e unidirecionadas, já que se dirigem à realização de interesses comuns.

55 Não negamos que o reconhecimento da natureza contratual dos contratos de colaboração (convênios administrativos colaborativos firmados com a iniciativa privada de interesse público) se apresenta, hoje, muito mais fácil de ser feito. É que, como bem observa Carlos Ari SUNDFELD e Rodrigo Pagani de SOUZA (2011, p. 53), as parcerias públicas com as entidades sem fins lucrativos no Brasil passaram por mutações
} 
Sucede que tanto no convênio [em sentido amplo] quanto no contrato existem vontades dirigidas à realização dum único negócio (interesses enantiomórficos, complementares), com obrigações recíprocas assumidas por todos os envolvidos, estando a sua satisfação na dependência da entrega da prestação com a qual se comprometeram as partes $^{56}$.

Parece-nos falaciosa, então, a ideia de que as posições jurídicas dos partícipes dum convênio [lato sensu] são idênticas, pois, embora persigam um objetivo comum, cada um assume uma prestação própria - e complementar -, obrigando-se em relação aos demais convenentes, que possuem legítima expectativa de realização do objeto pactuado, podendo, assim, demandar o cumprimento da obrigação devida pelos demais partícipes. Nesse diapasão, embora os convenentes estejam livres para denunciar o convênio a qualquer tempo, eles não são, exatamente da mesma forma que ocorre com os contratos em geral, irresponsáveis em relação aos interesses da outra parte. Nessa linha, pensamos não ser inerente aos convênios a precariedade do vínculo, revelando-se perfeitamente admissível, por conseguinte, a sanção por descumprimento ${ }^{57}$.

especialmente a partir do século XXI: da vagueza do objeto, falta de reciprocidade das obrigações de parte a parte, burocracia do controle e precariedade do vínculo presentes nas parcerias tradicionais, passou-se, nas parcerias modernas, a exigir perfeita definição do seu objeto, fixação de obrigações de parte a parte com grau de reciprocidade, controle focado no resultado e vínculo firme e permanente.

${ }^{56}$ Carlos Ari SUNDFELD e Rodrigo Pagani de SOUZA (2011, p. 52) assinalam que, modernamente, mais do que obrigações claras e específicas, essas parcerias [contratos de colaboração] se notabilizam por instituir obrigações com certo grau de reciprocidade de parte a parte, fixadas de tal modo que o cumprimento de dada obrigação por uma das partes seja o motivo para a exigibilidade do cumprimento de outra obrigação pela outra parte, a exemplo do condicionamento da liberação de recursos pelo Poder Público à execução satisfatória da prestação assumida pelo parceiro não estatal. Para os Autores, “[...] agora a tendência é a fixação de um cronograma de liberação de recursos em estrita consonância com a demonstração do cumprimento de etapas intermediárias ou metas pelo executor [privado]". Também é essa a posição de Fernando Dias de MENEZES DE ALMEIDA (2012, p. 236-246), para quem é o próprio Direito Brasileiro reconhece a natureza obrigacional dos vínculos formais convencionais colaborativos, que criam situações jurídicas para os partícipes, com direitos e obrigações exigíveis juridicamente. Nessa mesma toada, Floriano Peixoto de Azevedo MARQUES NETO (2005, p. 117) assenta que os convênios são contratos em sentido amplo (acordos de vontade), na medida em que criam obrigações relativas para as partes conveniadas, particularizando-se pela [suposta] ausência de sinalágma, reciprocidade e antagonismo obrigacional. Por sua vez, comentando os termos de parceria celebrados com as organizações da sociedade civil de interesse público, Marcela Roza Leonardo ZEN (2008, p. 84) coloca que "A entidade deve realizar o programa de trabalho pactuado dentro dos prazos estipulados e com a qualidade prevista. O parceiro público deve orientar, supervisionar e cooperar na implementação do projeto, liberar os recursos que constam do cronograma de desembolso, além de exigir probidade e qualidade nos serviços prestados pela OSCIP”. Finalmente, conquanto negue a natureza contratual, o próprio Diogo de Figueiredo MOREIRA NETO (2014, p. 207) também reconhece que a coordenação de vontades [por coordenação ou por colaboração] gera conteúdo obrigacional, exigindo prestações dos partícipes.

${ }^{57}$ Gustavo Alexandre MAGALHÃ̃ES (2012, p. 184-185) leciona ser impossível distinguir os convênios dos contratos com base na precariedade do vínculo, o que representaria "grande equívoco quanto à compreensão não só dos convênios, mas também do próprio instituto do contrato”, porquanto que a precariedade do vínculo decorreria da possibilidade de uma das partes rescindi-lo a qualquer tempo sem que a ruptura acarretasse para a outra parte direito à indenização [ou alguma forma de sancionamento], deixando de existir sempre que se apusesse um prazo determinado de duração. Para nós, a precariedade inexiste nos contratos de colaboração não 
Perfilhamos, portanto, a posição assumida pelo já aludido Anteprojeto de Normas Gerais sobre a Administração Pública Direta e Indireta, as Entidades Paraestatais e de Colaboração, que, em seu Título IV, emprega a expressão contrato público de colaboração para designar todo e qualquer meio de cooperação entre o Estado e organizações da sociedade civil sem fins lucrativos no desempenho de atividades, ações ou programas de relevância pública, deixando claro, por conseguinte, ser contratual a natureza jurídica dessas parcerias sociais entre os setores público e privado ${ }^{58}$.

Carlos Ari SUNDFELD e Rodrigo Pagani de SOUZA (2013, p. 43) vão além, afirmando que as modernas parcerias com o terceiro setor assemelham-se aos contratos de prestação de serviços, [supostamente] porque, diferentemente dos vínculos tradicionais de colaboração, o parceiro não estatal presta serviços à coletividade e recebe do parceiro privado estatal, em contraprestação, pagamentos em recursos financeiros ${ }^{59}$.

Em decorrência da natureza contratual dos convênios, a competência constitucional legislativa para discipliná-los é concorrente, cabendo à União, nos termos do inciso XXVII do art. 22 da Constituição Federal de 1988, a edição de normas gerais sobre qualquer

apenas quando fixado um lapso certo de duração da parceria, mas também sempre que forem estabelecidos objetivos e metas precisos como contrapartida ao fomento estatal, sujeitando o parceiro privado que desista de persegui-los não apenas à perda do incentivo oficial, mas também a sanções previstas em lei e no instrumento colaborativo. Nesse exato diapasão, Carlos Ari SUNDFELD e Rodrigo Pagani de SOUZA (2011, p. 53) defendem que, enquanto a parceria tradicional - os Autores reconhecem mutações nos vínculos colaborativos desenvolvidos no Brasil a partir do século XXI - se notabiliza pela precariedade, dizendo-se passíveis de denúncia a qualquer tempo pelos partícipes, sem que se antevissem maiores consequências jurídicas para a abrupta retirada de um deles; a moderna parceria pretende ser firme e estável, prevendo-se para o parceiro que se retira o dever de indenizar os danos causados em virtude da sua saída, além da sujeição a sanções em caso de inadimplência na execução do pacto. Registre-se, inclusive, que o próprio inciso XVI do art. 42 da novel Lei Federal no 13.019/2014 prevê como cláusula essencial dos termos de colaboração e de fomento a "faculdade dos partícipes rescindirem o instrumento, a qualquer tempo, com as respectivas condições, sanções e delimitações claras de responsabilidade (art. 73), além da estipulação de prazo mínimo de antecedência para a publicidade dessa intenção, que não poderá ser inferior a 60 (sessenta) dias”, o que espanca qualquer dúvida sobre a natureza obrigacional de tais instrumentos de parceria, com a responsabilização da entidade privada colaboradora em caso de descumprimento dos compromissos assumidos.

${ }^{58} \mathrm{O} \S 4^{\circ}$ do art. 73 do Anteprojeto estabelece que "Sujeita-se ao regime do contrato público de colaboração todo instrumento que institua vínculo de colaboração, nos termos definidos nesta Lei, independentemente da terminologia utilizada na legislação específica, que será aplicada subsidiariamente".

59 Percebe-se que os Autores praticamente equiparam os contratos de colaboração com as concessões administrativas da Lei Federal $n^{\circ} 11.079 / 2004$ quando a Administração figura como usuária indireta dos serviços públicos prestados pelo particular contratado $\left(\operatorname{art} .1^{\circ}, \S 2^{\circ}\right.$ ). Com o devido respeito, esse não nos parece o melhor entendimento, especialmente porque não existe relação de equivalência (sinalágma) entre as prestações dos parceiros, não se medindo a contribuição estatal ao projeto comum pela quantidade de serviços desenvolvidos pela entidade de colaboração, não se falando, portanto, em remuneração propriamente dita. Com efeito, a ação estatal é de fomento, o qual sequer precisa ser em recursos financeiros. Essa [discutível] premissa dos Autores, contudo, possui um objetivo claro em sua construção teórica acerca dos contratos de colaboração: enquanto contraprestação equivalente pelos serviços de relevância pública prestados pelos parceiros privados em favor da sociedade, os recursos públicos transferidos seriam privados, assegurando-se, assim, certa flexibilidade em seu gerenciamento. A natureza dos recursos públicos repassados às entidades de colaboração será examinada em capítulo próprio na segunda parte deste trabalho. 
modalidade de contratação administrativa, podendo os Estados, Municípios e Distrito Federal legislar suplementarmente conforme o princípio da predominância do interesse, nos termos dos arts. $24, \S 2^{\circ}, 25, \S 1^{\circ}$, e 30, I, todos da Lei Maior Brasileira ${ }^{60}$.

Por outro lado, pensamos não se aplicar o inciso XXI do art. 37 da Constituição Federal, restrito que está à contratação de obras, serviços, compras e alienações a partir da noção de retribuição/remuneração/pagamento, com garantia do equilíbrio econômico financeiro pelo Poder Público, referindo-se, pois, aos mencionados contratos administrativos clássicos, regidos pela Lei Federal no 8.666/1993 ${ }^{61}$.

Ocorre que, como bem esclarece a epígrafe dessa Lei, ela foi elaborada basicamente com fundamento no inciso XXI do art. 37 da Constituição Federal, regulamentando a contratação de obras, serviços, compras e alienações da Administração Pública segundo a lógica [retributiva/remuneratória] do tradicional contrato administrativo, fixando o regime jurídico da licitação pública e as cláusulas que estabeleçam obrigações de pagamento, mantidas as condições efetivas da proposta (preservação do equilíbrio econômicofinanceiro do contrato). A Lei Geral de Licitações, portanto, não busca fundamento de validade no inciso XXVII do art. 22 da Constituição Federal Brasileira, apenas dele se utilizando para estender aos convênios algumas de suas disposições, desde que compatíveis com o regime de cooperação harmônica e equilibrada que lhe é próprio, exatamente nos termos do referido art. 116 da Lei ${ }^{62}$.

Para nós, enfim, as parcerias sociais entre os setores público e privado aqui estudadas ostentam a natureza jurídica de contrato, submetendo-se, por conseguinte, à

\footnotetext{
${ }^{60}$ Em sentido oposto, Diogo de Figueiredo MOREIRA NETO (2014, p. 195) entende que, como os convênios e outros acordos do gênero seriam pactos sem natureza contratual, eles não estariam abrangidos pela competência federal do art. 22, XXVII, da Constituição, de modo que cabe a cada entidade política, no desempenho de seus respectivos poderes administrativos, dispor sobre essas figuras. Nessa toada, complementa o Autor que o dispositivo do art. 116 da Lei Federal no 8.666/1993 não seria norma geral, aplicando-se portanto, exclusivamente à Administração Pública Federal, e, pela mesma razão, o seu $\S 2^{\circ}$ seria inconstitucional, por invadir a competência dos Estados, Distrito Federal e Municípios para disporem sobre sua organização política e administrativa (art. 18 da Constituição).

${ }^{61}$ Não é esse, contudo, o entendimento de Maria Sylvia Zanella DI PIETRO (2011, p. 231), segundo a qual, se os convênios tivessem natureza contratual, o art. 116 da Lei de Licitações não lhes teria determinado a aplicação "no que couber", porque a incidência da Lei Federal n ${ }^{\circ} 8.666 / 93$ já decorreria dos arts. $1^{\circ}$ e $2^{\circ}$ deste diploma normativo. Assinale-se que, embora rejeite a natureza contratual dos convênios administrativos colaborativos em geral, a Autora (2015, p. 296-297) justifica a referência a normas gerais contida na epígrafe da recente Lei Federal $n^{\circ}$ 13.019/2014 no fato de tratar-se de matéria de contratação e licitação, inserida na competência privativa da União, por força do art. 22, XXVII, da Constituição Federal.

${ }^{62}$ Não negamos ser profundamente problemática a extensão das disposições da Lei Federal no 8.666/1993 aos convênios feita por esse art. 116, não existindo efetivamente um critério seguro para a aplicação das suas normas "naquilo que couber". É bem por isso que o art. 84 da recente Lei Federal n 13.019/2014 excluiu expressamente a incidência da Lei de Licitações nas relações de fomento e de colaboração disciplinadas no novel diploma normativo.
} 
competência constitucional legislativa da União para a edição de normas gerais, admitindose a disciplina suplementar pelos Estados, Municípios e Distrito Federal naquilo que envolver o seu interesse legítimo, não se aplicando as normas editadas com fulcro no XXI do art. 37 da Constituição Federal.

\subsection{Da Natureza de Fomento Administrativo}

O reconhecimento da natureza instrumental de fomento dos contratos de colaboração possui consequências importantes para o seu regime jurídico, notadamente no que se refere ao papel do Estado no vínculo cooperativo e à natureza dos recursos por ele repassados ao parceiro privado ${ }^{63}$.

Diogo de Figueiredo MOREIRA NETO (2014, p. 578) conceitua o fomento público como “[...] o estímulo oferecido direta, imediata e concretamente pela Administração, na forma da lei, a iniciativas reconhecidas como de interesse geral para o progresso e aperfeiçoamento do homem em sociedade”, destacando a marca consensual (não coercitiva) dessa função administrativa, que depende do consenso dos seus beneficiários ${ }^{64}$. Explica o Autor (2009, p. 134-135) que, também conhecido como atividade propulsora, o fomento público é expressão da Administração Consensual, perspectiva do Estado Democrático de Direito, o qual procura, por todos os meios a seu alcance, por à disposição do maior número de indivíduos instrumentos de desenvolvimento econômico e do progresso sociocultural, adotando medidas capazes de incentivar a iniciativa privada de interesse coletivo.

A primeira sistematização do estudo do fomento público é atribuída ao espanhol Luís JORDANA DE POZAS (1949, p. 46), para quem se trata de atuação administrativa destinada a promover, incentivar ou proteger atividades que atendam às necessidades públicas, sem usar coação ou criar serviços públicos [sem criar barreiras de acesso à iniciativa privada], correspondendo a uma via intermédia entre a inibição e o intervencionismo estatal que pretende conciliar a liberdade com o bem comum mediante a

\footnotetext{
${ }^{63}$ Escapa aos objetivos do presente trabalho a realização dum estudo aprofundado do fomento público, interessando-nos apenas apresentar uma noção dessa atividade administrativa, especialmente a partir da visão da doutrina estrangeira e brasileira, visando a caracterizar os contratos de colaboração como verdadeiros instrumentos de fomento estatal.

${ }^{64}$ Para Marcos Juruena Viellela SOUTO (2007, p. 15), fomento é noção mais restrita que a de estímulos positivos, na medida em que esta traduz a "criação de um cenário favorável aos investimos", ao passo que aquela é o "incentivo ao desempenho de determinada função de interesse do agente fomentador".
} 
influência indireta sobre a vontade dos indivíduos, a levá-los a querer justamente o que convém à satisfação das necessidades/utilidades públicas.

Ainda de acordo com Luís JORDANA DE POZAS (1949, p. 51-52), o fomento administrativo se revela das mais variadas formas, sendo impossível a catalogação de todos os seus instrumentos, podendo ser de caráter positivo, através da outorga de bens ou vantagens aos particulares, ou negativo, por meio da imposição de obstáculos ou cargas que dificultam as atividades opostas àquelas que o Estado pretende estimular. Os contratos de colaboração são, então, espécie de fomento administrativo positivo.

Um aspecto de especial importância da atividade de fomento estatal é a ausência de coação, sendo sua marca a voluntariedade da adesão dos agentes incentivados, donde resulta a impossibilidade de chamar propriamente de fomento público qualquer suporte dado pelo Estado de forma verticalizada e obrigatória, a exemplo do que ocorre, no Brasil, com os serviços sociais autônomos e as entidades qualificadas diretamente pela lei como organizações sociais ${ }^{65}$. Enquanto instrumento de fomento administrativo, por conseguinte, somente podem ser chamados de contratos de colaboração aquelas ferramentas de parceria no setor social livremente pactuadas entre o Estado e a iniciativa privada sem fins lucrativos ${ }^{66}$.

Maria Sylvia Zanella DI PIETRO (2012, p. 35) anota que a intensificação do fomento público é uma das decorrências da aplicação do princípio da subsidiariedade, a partir da lógica de que a não intervenção direta do Estado naquelas atividades em que os particulares têm condições de assumir satisfatoriamente impõe, como contrapartida, a fim de garantir os interesses públicos, a coordenação, fiscalização e estímulo à iniciativa privada.

Nessa mesma toada, Silvio Luís Ferreira ROCHA (2006, p. 20) afirma que, dentre as atividades administrativas do Estado, o fomento é a que sofre maior influência do princípio da subsidiariedade, constituindo-se num dos seus instrumentos. De acordo com o

\footnotetext{
${ }^{65}$ Lembre-se que a Lei Federal no 9.637/1998 promoveu a extinção de duas estruturas administrativas, o órgão Laboratório Nacional de Luz Síncroton e a entidade Fundação Roquette Pinto (art. 21), apontando em seu Anexo I as entidades da sociedade civil autorizadas a serem qualificadas como OSs e a absorver tais componentes da Administração Pública.

${ }^{66}$ Nesse mesmo sentido, Héctor Jorge ESCOLA (1990, p. 858-859) explica que a atividade administrativa de fomento se dedica a proteger e promover de forma não coativa aquelas atividades não estatais voltadas à realização do interesse público [de atendimento das necessidades coletivas ou de utilidade geral], orientada a ação dos particulares por sua própria decisão, enquanto colaboradores da Administração Pública, numa participação essencialmente voluntária. Marcos Juruena Villela SOUTO (2007, p. 17) pondera, contudo, que, após a [livre] adesão aos programas [facultativos] de fomento público, o particular se obriga a cumprir as metas cuja implementação é incentivada.
} 
Estudioso, o fomento administrativo erige-se sobre o suposto de que existem atuações privadas [não estatais] que satisfazem interesses públicos e, por isso, devem ser por ela instigadas e subsidiadas.

Essa relação entre o princípio da subsidiariedade e o fomento administrativo deixa claro não ser o Estado como um todo subsidiário, mas apenas a sua intervenção direta enquanto prestador /executor -, a qual, em nome dos fundamentos constitucionais da cidadania (art. $1^{\circ}$, II), da democracia participativa (art. $1^{\circ}$, par. único) e da livre iniciativa (art. $1^{\circ}$, IV), deve ter lugar apenas quando os próprios particulares se mostrarem desinteressados, ineficientes ou insuficientes para o adequado atendimento das necessidades coletivas.

Sem embargo, a prioritária retirada do Estado da prestação direta de serviços sempre exigirá, em contrapartida, tarefas outras que assegurem o atingimento dos fins públicos colimados, através justamente do fomento e da regulação administrativos, jamais se desincumbindo da realização dos interesses públicos de que é garantidor. O princípio da subsidiariedade, então, provoca tão somente uma mudança na forma de atuação do Estado, o qual legitimamente, em respeito aos próprios comandos constitucionais, concentra as suas forças no estímulo e fiscalização da iniciativa privada de interesse público.

Na ordem econômica, a Constituição Federal de 1988 expressamente determina a excepcionalidade da intervenção direta estatal (art. 173), atribuindo-lhe o papel prioritário de agente fomentador e regulador de atividades econômicas (art. 174). Diferentemente, inexiste igual previsão no texto constitucional para a ordem social, havendo, na verdade, uma série de dispositivos prevendo a execução direta de serviços sociais pelo Poder Público ${ }^{67}$. É por essa razão que boa parte da doutrina nacional defende a inaplicabilidade do princípio da subsidiariedade à ordem social, destacando a impossibilidade da Administração Pública substituir meios de ação direta por instrumentos indiretos de intervenção, justamente como é o caso do fomento administrativo ${ }^{68}$.

\footnotetext{
${ }^{67}$ A Constituição Federal exige, por exemplo, que o Estado Brasileiro preste diretamente serviços de saúde (arts. 196), de previdência social (arts. 201-) e de educação (arts. 205-), admitindo a prestação não estatal nesses casos apenas de forma complementar (arts. 199, 202 e 205, respectivamente).

${ }^{68}$ Sílvio Luís Ferreira da ROCHA (2006, p. 19) entende que a Administração Pública Brasileira não pode livremente optar por formas jurídicas de atuação e substituir os meios diretos de agir pelos indiretos, porquanto o a Constituição Federal de 1988 exige a prestação de serviços públicos de saúde e de educação pelo próprio Estado. É também a posição de Alberto Shinji HIGA (2010, p. 124-125), para quem o papel da iniciativa privada nas atividades de interesse público é complementar, não se admitindo que o fomento público substitua a ação direta estatal por completo. Nesse mesmo diapasão, José Roberto Pimenta OLIVEIRA (2006, p. 531) chega ao ponto de inverter a lógica da subsidiariedade, afirmando que "O fomento constitucional legítimo é
} 
Para nós, entretanto, o princípio da subsidiariedade é perfeitamente aplicável à ordem social, sendo o fomento por meio de parcerias com a iniciativa privada sem fins lucrativos um dos seus principais instrumentos, senão vejamos: o dever do Estado em relação aos interesses públicos é de garantia/realização ${ }^{69}$, não se tratando de próprio estatal, inexistindo determinação constitucional para a intervenção direta generalizada do Estado nos serviços sociais, somente sendo obrigatória a exploração imediata de serviços sociais pelo próprio Poder Público nos casos expressos constitucionais; a Constituição Brasileira de 1988 coloca a livre iniciativa como fundamento da República (art. $1^{\circ}$, IV), orientando a leitura de todo o corpo constitucional; e a cidadania (art. $1^{\circ}$, II) e a democracia (arts. $1^{\circ}$, caput, e 14) garantem o direito de participação popular nos negócios públicos, pelo que a priorização dos meios indiretos de ação estatal é verdadeira máxima constitucional, não se tratando de opção complementar à intervenção direta do Poder Público ou mesmo de livre alternativa política dos governantes ${ }^{70}$.

É justamente nessa perspectiva que Diogo de Figueiredo MOREIRA NETO (2006, p. 357-358) observa que, a partir da segunda metade do século XX, a sociedade passa a ser vista como a real titular do interesse público, cabendo ao Estado desempenhar nada mais do que um papel instrumental relativamente às necessidades coletivas, de modo que a ordem

norteado pelo princípio da subsidiariedade, não autorizando mera e desvirtuada substituição do aparelho administrativo, por figurino jurídico privatístico, mantida a significativa participação de recursos público (verbas, bens e pessoal) no exercício da atividade", quando, na verdade, o fomento administrativo é um instrumento/decorrência da aplicação do princípio da subsidiariedade. Igualmente, Fernando Herren AGUILLAR (2011, p. 28) assevera que as funções públicas seriam as atribuições irrenunciáveis do Estado, previstas na Constituição Federal Brasileira e das quais ele não pode se desvencilhar porque, assim procedendo, descaracterizaria a sua própria existência. Finalmente, esse também foi o entendimento esposado pelo Ministro do Supremo Tribunal Federal Ayres BRITTO ao proferir o seu voto de relatoria no exame do mérito da ADI $\mathrm{n}^{\circ} 1.923 / \mathrm{DF}$, defendendo, numa perspectiva estatizante, ser inconstitucional toda e qualquer norma jurídica que afaste o Estado da prestação direta dos serviços sociais. Sob esta ótica, afirma que, dos sistemas de saúde, educação e previdência social, por exemplo, os particulares podem apenas participar de forma complementar. ${ }^{69} \mathrm{O}$ arcabouço constitucional brasileiro deixa clara que a obrigatoriedade estatal nos serviços sociais é de garantia, ora lhe impondo a execução direta - tal como ocorre com os serviços de saúde (arts. 196-), de previdência social (arts. 201-) e de educação (arts. 205-) -, ora simplesmente lhe reservando o precioso papel de fomentador e regulador da iniciativa privada de interesse público - a exemplo da cultura (arts. 215-), do desporto (art. 217) e da ciência e tecnologia (arts. 218-).

${ }^{70}$ É por essa razão que não concordamos com a posição de Carolina Caiado LIMA (2010, p. 117) no sentido de que o fomento público seria necessariamente transitório, como se indispensável fosse a evitar protecionismos desarrazoados. Para nós, a priorização dos meios indiretos de intervenção estatal - dentre os quais o fomento desponta com força maior em recorrência e efetividade - é uma imposição constitucional, inexistindo qualquer óbice jurídico à perenidade dessa atividade administrativa. Obviamente, isso não quer dizer que, concedidos estímulos oficiais a determinada entidade privada, o Estado deva assim continuar, quase como se existisse direito adquirido da organização ao fomento implementado. Respeitadas as obrigações assumidas pelo Estado - contratualmente, tal como ocorre com os contratos de colaboração em estudo, ou através de programas especiais de fomento estatal -, o Poder Público poderá sempre rever as suas prioridades e redesenhar a sua estratégia de ação, redirecionando os incentivos que vinham sendo concedidos, valendo-se de outras formas de intervenção mediata ou mesmo decidindo, justificadamente, pela ingerência direta econômica ou social. 
jurídica outorga à estrutura estatal apenas uma titularidade para a prossecução da realização dos interesses públicos, não havendo interdição aos membros da sociedade de persegui-los autonomamente, fiscalizar a atuação estatal e contestar a sua condução, operando pelos instrumentos de participação. Ainda segundo o Autor (2014, p. 606), o princípio da subsidiariedade determina o reconhecimento da "prioridade da atuação dos corpos sociais sobre os corpos políticos no atendimento de interesses gerais, só justificando cometimentos administrativos depois que a sociedade, em seus diversos níveis de organização, vier a necessitar de atuação subsidiária do Estado" [Grifos no original $]^{71}$.

Nesse mesmo diapasão, no julgamento do mérito da mencionada ADI n ${ }^{\circ}$ 1.923/DF, o ex-Ministro Luiz FUX (2011, p. 17-18) não vislumbrou qualquer inconstitucionalidade na priorização dos meios indiretos de ação estatal no domínio social, votando no sentido de que o Plano Nacional de Publicização previsto na Lei Federal n 9.637/1998 (Lei das Organizações Sociais) não afrontaria a Constituição Brasileira, pois não traduziria uma renúncia do Estado aos seus deveres de garantir a prestação dos serviços sociais, representando apenas uma mudança, advinda de uma legítima decisão política, na forma de sua concretização, a ser efetivada pela intervenção indireta do Estado no campo social, não havendo óbice constitucional algum à priorização do fomento estatal à iniciativa privada. Em suas próprias palavras:

[...] como regra, cabe aos agentes eleitos a definição de qual modelo de intervenção, direta ou indireta, será mais eficaz no atingimento das metas coletivas conclamadas pela sociedade brasileira, definindo o modelo de atuação que se mostre mais consentâneo com o projeto político vencedor do pleito eleitoral [...] e é justamente dessa forma, optando pelo fomento acompanhado de uma regulação intensa, que os serviços públicos sociais ainda continuarão a ser efetivados pelo Estado brasileiro após a vigência da Lei 9.637/98 - e como de fato vêm sendo -, através da colaboração público-privado. [...] Portanto, o Poder Público não renunciou aos seus deveres constitucionais de atuação nas áreas de saúde, educação, proteção ao meio ambiente, patrimônio histórico e acesso à ciência, mas apenas colocou em prática uma opção válida por intervir de forma indireta para o cumprimento de tais deveres, através do fomento e da regulação. Na essência, preside a execução deste programa de ação a lógica de que a atuação privada será

\footnotetext{
${ }^{71}$ Diogo de Figueiredo MOREIRA NETO (2014, p. 588-596; 604-612) classifica o fomento administrativo quanto aos fins visados, em de planejamento estatal, sociais, econômicos e institucionais, sendo possível inserir os contratos de colaboração no: (i) fomento social, na medida em que se dirigem diretamente ao homem, contribuindo para o seu digno e produtivo numa sociedade livre e educada, voltando-se aos setores da família, da criança e do adolescente, dos idosos, dos índios, da educação, pesquisa e informação, do trabalho, da cultura, lazer, desporto e turismo, dentre outros componentes da chamada "ordem social"; e (ii) fomento institucional, porquanto destinados ao setor público não estatal, incentivando os entes intermédios criados pela sociedade para o desempenho de atividades de colaboração entre os setores públicos e privados, convergentes para os mesmos interesses públicos.
} 
mais eficiente do que a publica em determinados domínios, dada a agilidade e a flexibilidade que dominam o regime de direito privado.

Trata-se de posição forte nas lições de Paulo Eduardo Garrido MODESTO (2001, p. 14-15), que pondera, entretanto, a irrenunciável compensação estatal à sua saída da prestação imediata dos serviços sociais nos seguintes termos:

[...] Não prover diretamente o serviço não quer dizer tornar-se irresponsável perante essas necessidades sociais básicas. Não se trata de reduzir o Estado a mero ente regulador. O Estado apenas regulador é o Estado mínimo, utopia conservadora insustentável ante as desigualdades sociais atuais. Não é este o Estado que se espera resulte das reformas em curso em todo o mundo. O Estado deve ser regulador e promotor dos serviços sociais básicos e econômicos estratégicos. [...] Os serviços sociais devem ser fortemente financiados pelo Estado, assegurados de forma imparcial pelo Estado, mas não necessariamente realizados pelo aparato do Estado. [...] Desde que cumpridos os requisitos de salvaguarda do interesse público, mais intensos e onerosos quanto mais ampla for a transferência de encargos e recursos, a cooperação é lícita e até mesmo incentivada pela Constituição da República ${ }^{72}$.

Resta-nos concluir, portanto, que o princípio da subsidiariedade é, sim, aplicável à ordem social, sendo o fomento público [e a correlata ação de regulação] atividade prioritária do Estado também nos serviços sociais, de modo que, salvantes as determinações constitucionais específicas, a intervenção estatal direta apenas se justifica na hipótese de se mostrar desinteressada, ineficiente ou insuficiente a iniciativa privada ${ }^{73}$.

Nessa medida, deve-se obtemperar a afirmação de Sílvio Luís Ferreira da ROCHA (2006, p. 26-27) de que, afora os casos expressos em lei, a atividade administrativa de fomento é facultativa para o Estado, tratando-se duma decisão política de conveniência e oportunidade, não passível de ser juridicamente exigida ${ }^{74}$. É que exatamente o princípio da subsidiariedade e o direito fundamental de participação nos negócios públicos impõem ao

\footnotetext{
${ }^{72}$ Esse também é o entendimento de Diogo de Figueiredo MOREIRA NETO (2014, p. 606), que, falando em delegação social enquanto todo e qualquer forma de devolução à sociedade organizada daquelas atividades que, não obstante específico e definido interesse público, dispensem o tratamento político-burocrático e, ordinariamente, o pesado e oneroso emprego do aparelho coercitivo estatal, assevera que o Poder Público nunca perderá o controle dos processos que defere à sociedade, apenas se retraindo numa atuação subsidiária, com atividades de acompanhamento, de fiscalização e de controle dessas atividades não estatais quanto à sua higidez e eficiência.

${ }^{73}$ De acordo com Luís JORDANA DE POZAS (1949, p. 41), nos Estados em que se aceita a ordem individual, somente se estimam públicas [estatais] aquelas necessidades que as pessoas não podem satisfazer livremente por si mesmas, pelo que o fomento se revela, sim, uma atividade prioritária da Administração Pública, garantidora que é dos valores intrínsecos da justiça e da liberdade, a conferir autonomia aos grupos intermédios, os quais passam a ser diretamente responsáveis pelos rumos da coletividade (Silvia Faber TORRES, p. 200, p. 165).

${ }^{74}$ Acompanhando esse pensamento: Carolina Caiado LIMA (2010, p. 69).
} 
Estado a priorização dos meios indiretos de intervenção, dentre os quais se destaca o fomento, não se mostrando legítimo e responsivo, por conseguinte, o negligenciamento do incentivo à iniciativa privada. Por sua vez, embora reconheçamos ser política a escolha do grau de utilização dos diversos meios indiretos de intervenção (regulação, planejamento ${ }^{75} \mathrm{e}$ fomento), parece-nos claro que o Poder Público jamais poderá fazer tabula rasa de quaisquer dessas ferramentas de intervenção mediata, simplesmente não as utilizando. Outrossim, decidindo politicamente por programas de fomento público - por meio, por exemplo, da edição de leis específicas de incentivo a determinados setores, ou, no nosso caso, de leis que instituem instrumentos de parceria com a iniciativa privada sem fins lucrativos -, é claro que o Estado se vincula ao fomento oferecido, com a possibilidade de ser demandado por aquele particular que se sentir preterido no acesso aos estímulos disponibilizados.

Enquanto expressão do fomento positivo ${ }^{76}$, os contratos de colaboração envolvem a outorga de vantagens, prestações ou bens em favor dos particulares que prossigam, acentuem ou levem a cabo de determinada maneira atividades que a Administração decidiu estimular, não se limitando à transferência de recursos financeiros.

Segundo Luís JORDANA DE POZAS (1949, p. 52-53), quanto ao tipo de vantagens entregues ao particular, o fomento administrativo se classifica em: (i) honorífico, englobante das distinções e recompensas outorgadas como reconhecimento ou proclamação pública de um ato ou de uma conduta exemplar, a exemplo das condecorações, tratamentos, títulos, preeminências, uso de emblemas ou símbolos determinados, troféus, diplomas,

\footnotetext{
${ }^{75}$ Indo além do reconhecimento de que o planejamento estatal está intimamente ligado ao fomento público (ambos consagrados no art. 174 da Constituição Federal), Diogo de Figueiredo MOREIRA NETO (2014, p. 579 ) inclui o primeiro no segundo, colocando-o como seu fundamento racionalizador. Da mesma forma, Célia Cunha MELLO (2003, p. 76 e 81) defende que o fomento público somente se legitima se precedido de substancial planejamento estatal, indispensável que é à eliminação de protecionismos a determinados setores e otimização da concretização dos objetivos de interesse público perseguidos.

${ }^{76}$ Baseando-se na classificação inaugurada por Luís JORDANA DE POZAS (1949, p. 51-53), Héctor Jorge ESCOLA (1990, p. 859-865) divide o fomento público, quanto à forma de atuação sobre a vontade do particular, em positivo (outorga de bens e benefícios aos particulares como forma de atrai-los ao desenvolvimento de atividades queridas pelo Poder Público) e negativo (criação de obstáculos ou ônus para indiretamente dissuadir a iniciativa privada da realização de atividades contrárias à que o Estado pretende fomentar), e, quanto ao tipo ou classe de vantagens outorgadas, em fomento honorífico, econômico e jurídico.
} 
dentre outros ${ }^{7778}$; (ii) econômico, determinante da percepção de um numerário ou a dispensa de um pagamento obrigatório, como é o caso das subvenções, prêmios em dinheiro, empréstimos, garantias de juros e isenções e demais privilégios de caráter fiscal ${ }^{79}$; e (iii) jurídico, outorgante duma condição privilegiada que, de modo indireto, representa vantagens econômicas ou de segurança ${ }^{80}$.

77 Sílvio Luís Ferreira da ROCHA (2006, p. 36) observa existir quem questione a constitucionalidade do fomento honorífico, por considerá-lo incompatível com o princípio da igualdade, dado que, enquanto ato de reconhecimento público, sua razão radicaria mais na conveniência do Estado de efetuar gestos de apreço. Para nós, entretanto, é preciso diferenciar os atos de mero reconhecimento público, insertos muito mais no âmbito da política, na qual é inerente a discricionariedade dos governantes, dos atos administrativos de fomento honorífico, cuja outorga de títulos, condecorações e símbolos implica efetivamente um benefício indireto e somente se justifica quando voltado ao estímulo da iniciativa privada de interesse público. Não consideramos constitucional, portanto, qualquer previsão de discricionariedade da Administração Pública na realização da atividade administrativa de fomento, ainda que se trate da modalidade honorífica.

${ }^{78}$ Luís JORDANA DE POZAS (1949, p. 52-53) observa que os meios honoríficos de fomento podem levar consigo algumas vantagens de caráter jurídico ou econômico, essas, contudo, que serão sempre acessórias ao título, condecoração ou símbolo outorgado, sendo principal o enaltecimento social do beneficiado. Na prática, é mesmo muito difícil diferenciar o fomento meramente honorífico daquele jurídico ou econômico, porquanto quase nunca os benefícios concedidos se limitam a um único meio de incentivo. Segundo pensamos, entretanto, a exclusiva exortação social de pessoas, sem a concessão direta ou indireta de vantagens de caráter público, se insere muito mais no campo da política, na qual é ampla a discricionariedade dos governantes, não se tratando de atividade administrativa, não se submetendo, portanto, aos princípios constitucionais que norteiam o funcionamento da Administração Pública.

${ }^{79}$ De forma mais abrangente, Sílvio Luís Ferreira da ROCHA (2006, p. 36-37) leciona que os meios econômicos de fomento público se classificam em: (i) reais: prestação ou dação de coisas ou serviços da Administração aos particulares, sem encargos para estes [na verdade, sem caráter contraprestacional], que as recebem ou os utilizam nessas condições; (ii) fiscais: estabelecimento de isenções, imunidades, redução de alíquotas, remissão, anistia, diferimentos e fixação de prazos excepcionais de recolhimento tributários [cuja inclusão entre as técnicas de fomento é criticada, por ser medida geral de política econômica, necessariamente estabelecida em lei, de aplicação vinculada]; (iii) creditícios: oferecimento de linhas privilegiadas de crédito ou meios alternativos de financiamento; e (iv) meios econômicos em sentido estrito: ajudas ou vantagens financeiras dadas pela Administração aos destinatários da atividade de fomento, normalmente designados subvenções ou auxílios. Célia Cunha MELLO (2003, p. 75-76; 86-131), por sua vez, ensina que os meios econômicos de fomento podem abranger vantagens econômicas de caráter real, sem desembolso efetivo de dinheiro público em favor do sujeito fomentado, tal como ocorre com a cessão de uso de bens públicos e de servidores, gratuitamente ou a preços graciosos; ou vantagens de caráter financeiro, que se dividem em auxílios diretos (importam o desembolso efetivo de dinheiro pelo Poder Público, como atividades bancárias e operações financeiras, em condições favoráveis, e o apoio científico e tecnológico) e auxílios indiretos (correspondentes aos diversos meios de exoneração tributária, a exemplo de alíquotas menores, remissão, anistia, diferimentos, prazos mais vantajosos de recolhimento, isenções e imunidades, reduzindo a receita pública arrecadada pelo Estado. Finalmente, Carolina Caiado LIMA (2010, p. 73) divide os meios econômicos de fomento em: (i) diretos, quando há transferência de recursos financeiros, a exemplo das subvenções, auxílios e contribuições; e (ii) indiretos, que não pressupõem a transferência de tais numerário público, embora proporcionem estímulos mensuráveis economicamente, a exemplo dos benefícios fiscais, cessão de servidores e doação de bens. Esta última autora inclui no segundo grupo os benefícios ficais deferidos aos doadores de recursos privados às organizações da sociedade civil sem fins lucrativos, a exemplo da Lei de Incentivo ao Esporte - Lei Federal n ${ }^{\circ} 11.438 / 2006$, que, em seu art. $1^{\circ}$, permite a dedução de valores devidos a título de imposto de renda por pessoas físicas ou jurídicas despendidos com o patrocínio ou doação em favor de projetos desportivos ou paradesportivos previamente aprovados pelo Ministério do Esporte.

${ }^{80}$ De acordo com Sílvio Luís Ferreira da ROCHA (2006, p. 37), o fomento jurídico permite que o particular se beneficie da utilização ou emprego de meios jurídicos excepcionais, viabilizando-lhes poderes ou prerrogativas próprios da Administração Pública, ou que simplesmente ostente posição jurídica benéfica diferenciada, quase sempre consistente na dispensa, isenção ou suspensão de proibições estabelecidas pelas leis ou regulamentos. Este último caso corresponde exatamente aos títulos e certificações outorgados pelo Estado no âmbito federal (de utilidade pública, de entidade beneficente de assistência social, de OSCIP e de OS), cuja obtenção 
Encontramos no contrato de colaboração um misto desses mecanismos honoríficos, econômicos e jurídicos de fomento. Confira-se, por exemplo, o contrato de gestão com as OSs (Lei Federal n 9.637/1998) e o termo de parceria com as OSCIPs (Lei Federal $n^{\circ}$ 9.790/1999), que pressupõem a outorga de títulos jurídicos à pessoa jurídica não estatal sem fins lucrativos, certificação oficial passada pelo Poder Público ${ }^{81}$ que confere posição privilegiada, autorizadora da celebração de instrumento de parceria com a Administração não acessível à generalidade da iniciativa privada, viabilizando-lhes, assim, todos os benefícios econômicos previstos em lei ${ }^{82}$, tanto diretos (com transferência de recursos financeiros, a exemplo das subvenções, auxílios e contribuições ${ }^{83}$ ), quanto indiretos (que não pressupõem a entrega de numerário público, embora proporcionem estímulos mensuráveis economicamente, a exemplo dos benefícios fiscais, cessão de bens públicos e de servidores) ${ }^{84}$.

A caracterização do contrato de colaboração como instrumento de fomento social - por meio do qual o Estado confere vantagens (econômicas ou não, financeiras ou não) ao

proporciona às organizações da sociedade civil sem fins lucrativos benefícios diretos e indiretos, como o gozo de isenções tributárias, o recebimento de subvenções, auxílios e contribuições, além da autorização para firmar instrumentos de parceria com a Administração (Alberto Shinji HIGA, 2010, p. 147).

81 A qualificação da entidade como organização social importa, consoante o art. 11 da Lei Federal $n^{\circ}$ 9.637/1998, a sua declaração como entidade de interesse social e utilidade pública para todos os fins legais. O título de utilidade pública foi criado pela Lei Federal $n^{\circ}$ 91/1935 (e disciplinado pelo Decreto $\mathrm{n}^{\circ}$ 50.517/1961), estando em vigor ainda na atualidade - muito embora em desuso e desprestigiado (Paulo Eduardo Garrido MODESTO, 2006, p. 05-07), garantindo à entidade o uso exclusivo de emblemas, flâmulas, bandeiras e distintivos (assim como a menção ao título), sendo ainda pré-requisito para a isenção da não mais vigente "taxa de contribuição de previdência dos Institutos e Caixas de Aposentadorias e Pensões”. Sílvio Luís Ferreira da ROCHA (2006, p. 72) leciona que os efeitos jurídicos derivados da obtenção do título de utilidade pública [salvo os referidos benefícios honoríficos e habilitação para a isenção da aludida taxa] foram disciplinados em diversas outras leis, podendo ser resumidos: na possibilidade de oferecer dedução fiscal no imposto de renda, em doações de pessoas jurídicas; em ter acesso a subvenções e auxílios da União e suas autarquias; e na possibilidade de realizar sorteios, desde autorizados pelo Ministério da Justiça. Ainda no que diz respeito às organizações sociais, caso elas resultem da absorção de atividades de entidade federal extinta, poderão, nos termos do art. 22, VI, da Lei Federal $n^{\circ}$ 9.637/1998, adotar os símbolos designativos destes, seguidos da identificação "OS”, benefício evidentemente honorífico.

${ }^{82} \mathrm{Na}$ verdade, no caso das organizações sociais, a celebração do contrato de gestão também lhes viabiliza benefício não econômico, qual seja a possibilidade de serem contratadas com dispensa de licitação pela Administração Pública para a prestação dos serviços objeto da parceria (art. 24, XXIV, Lei Federal $n^{\circ}$ 8.666/1993).

${ }^{83}$ No plano federal, a disciplina desses meios econômicos diretos de fomento admitidos no âmbito dos contratos de colaboração pressupõe a conjugação das legislações que tratam especificamente de cada espécie colaborativa com o disposto na Lei Federal n ${ }^{\circ} 4.320 / 1964$, Lei Federal Complementar $n^{\circ} 101 /$ e na lei de diretrizes orçamentárias mais recente, devendo-se examinar ainda o teor do Decreto Federal $n^{\circ}$ 93.872/1986, da Portaria Interministerial MP/MF/CGU n ${ }^{\circ}$ 507/2011, dentre outros instrumentos normativos infralegais. Carolina Caiado LIMA (2010, p. 75 e 89) destaca que as diferenças entre as subvenções sociais, auxílios e contribuições residem na variedade de nomenclaturas adotadas pela legislação, no tipo de atividade fomentada, na natureza da entidade privada destinatária e na forma de autorização legislativa necessária à transferência dos recursos financeiros. Todos esses três meios econômicos diretos de fomento deverão, conforme estabelece o art. 26 da Lei Complementar Federal n ${ }^{\circ}$ 101/2000, estar previstos no orçamento ou em seus créditos adicionais, exigindo-se lei especial apenas para as contribuições.

${ }^{84}$ Estamos utilizando a referida classificação apresentada por Carolina Caiado LIMA (2010, p. 73). 
parceiro privado para estimulá-lo no desenvolvimento de atividades sociais - possui repercussões imediatas no regime jurídico dessas parcerias sociais entre os setores público e privado. Senão, vejamos:

Consoante Gustavo Justino de OLIVEIRA (2007c, p. 230-231), se por um lado o fomento opera uma "ampliação da esfera jurídica do destinatário", disponibilizando-lhes recursos públicos, por outro condiciona ou mesmo restringe o regime de direito privado ao qual as entidades não estatais beneficiadas estão originalmente submetidas, sendo-lhes instituídos pelo ordenamento jurídico procedimentos e obrigações que devem ser seguidos sob pena de responsabilização enquanto estiverem na posição de "gestoras privadas de recursos públicos para fins públicos".

Nessa mesma toada, Sílvio Luís Ferreira da ROCHA (2006, p. 27-34) ensina que "[...] A atividade de fomento, enquanto atividade administrativa, deve estar submetida ao regime jurídico administrativo, que, no Brasil, decorre, diretamente, da Constituição Federal", sendo informado pela supremacia e indisponibilidade do interesse público, devendo observar legalidade, impessoalidade, moralidade, publicidade e eficiência (art. 37, caput, CF/88), pela motivação (art. 93, X), igualdade (art. $5^{\circ}$, caput e I), e finalidade, além de outros princípios componentes do conhecido regime jurídico administrativo ${ }^{85}$.

Igualmente, Gaspar Ariño ORTIZ (2004, p. 348-355) afirma que, como toda atividade da Administração Pública, a ação de fomento estatal deve se orientar pelos princípios da legalidade, igualdade, livre concorrência e eficiência e economia dos gastos públicos, devendo a disponibilização de recursos públicos ser precedida de processo administrativo competitivo que garanta transparência, publicidade, objetividade e livre concorrência entre os interessados.

Por sua vez, Marcos Juruena Villela SOUTO (2007, p. 34) orienta que o controle dos mecanismos de fomento estatal é feito pelos órgãos de controle interno e externo da

\footnotetext{
${ }^{85}$ Para o Autor (2006, p. 31-32), "a estruturação funcional dos deveres-poderes administrativos promocionais deve estar consignada em lei, com a especificação clara das condições exigíveis de seus beneficiários, das limitações quantitativa e qualitativas das vantagens oferecidas, do âmbito material albergado pela atividade, do prazo previsto de vigência das medidas fomentadoras e, por fim, das limitações processuais a serem observadas no processo administrativo de concessão". Ainda segundo o Autor, o fomento legítimo será aquele que promova ou estimule atividades favorecedoras do bem estar geral; seja impessoal, assegurando a todos o direito de concorrer aos seus benefícios; e obedeça à razoabilidade e proporcionalidade, que impõem limites à sua configuração normativa, exigindo que ela seja adequada, necessária e ponderada aos valores constitucionais.
} 
Administração sob o tríplice aspecto da legalidade, legitimidade e economicidade (art. 70 da Constituição).

Silvio Luís Ferreira da ROCHA (2006, p. 33) acrescenta como específico do fomento administrativo o princípio da repartição de riscos ou do risco compartido, segundo o qual a ação promocional do Estado não deve ser encarada como mero ato de liberalidade administrativa, que exonere o beneficiário de todo o risco ou da obrigatoriedade de aportar recursos próprios para a atividade fomentada. Para ele, a repartição de riscos está consagrada no art. 16 da Lei Federal no 4.320/1964, o qual, ao tratar das subvenções sociais, faça em "suplementação de recursos de origem privada, indicando que o fomento pressupõe o aporte de recursos privados na atividade incentivada ${ }^{86}$.

Temos, então, que, exatamente por serem os contratos de colaboração instrumento de fomento público, espécie de atividade administrativa, a participação estatal será sempre orientada pelos princípios da Administração Pública:

- A legalidade administrativa exige que lei formal preveja a sua existência, as condições de celebração, os benefícios envolvidos e o sistema de controle, sem prejuízo da regulamentação infralegal pela própria Administração Pública, que, sem transbordar o quadro normativo da lei, poderá disciplinar pormenorizadamente as suas disposições ${ }^{87}$;

- A impessoalidade e eficiência impõem que a seleção das organizações parceiras do Estado ocorra através de procedimento objetivo que garanta a todos os interessados a oportunidade de disputar o estímulo estatal e que

\footnotetext{
${ }^{86}$ Essa também é a lição de Rita TOURINHO (2010, p. 326). Observamos, contudo, que o princípio da repartição de riscos ou do risco compartido não vem previsto expressamente na legislação que disciplina os mais variados instrumentos de parceria estatal não estatal no setor social brasileiro, embora esteja certamente relacionado a exigência de tempo mínimo de constituição prévia da entidade privada sem fins lucrativos parceira do Estado, nos termos do art. $3^{\circ} \S 2^{\circ}$, VI, do Decreto Federal no 6.170/2007, e no art. 23, § $1^{\circ}$, VII, "a", da Lei Federal $n^{\circ} 13.019 / 2014$. Embora seja princípio afinado com a supremacia do interesse público e a moralidade administrativa, idôneo a evitar a fuga [ilegal] do regime jurídico-administrativo ao impedir que a iniciativa privada se articule exclusivamente para gerir a estrutura administrativa, é necessário ponderar que não são devidas exigências que frustrem o caráter competitivo do procedimento de seleção das entidades privadas parceiras do Estado e que impeçam o direito de participação de instituições de pequeno porte. Não é por acaso que o art. 25 da Lei Federal n ${ }^{\circ}$ 13.019/2014 permite a "atuação em rede para a execução de iniciativas agregadoras de pequenos projetos, por duas ou mais organizações da sociedade civil”.

${ }^{87}$ Isso não significa que cada contrato de colaboração deverá se escoimar numa em autorização legislativa específica. Inclusive, o STF já se manifestou por diversas vezes acerca da inconstitucionalidade da exigência de autorização legislativa para a celebração de convênios contida em diversas Constituições Estaduais e Leis Orgânicas Municipais, por violação do princípio da separação dos poderes contido no art. $2^{\circ}$ da Constituição Federal. Para o Pretório Excelso, a decisão de celebrar convênios á ato de gestão do Poder Executivo, não se admitindo a intervenção do Legislativo. Nesse sentido, consultar: ADIs nº 342-9/PR e 770/MG.
} 
permita ao Poder Público escolher aquela entidade de melhor capacidade de atendimento das necessidades coletivas;

- A publicidade submete toda a relação de parceria ao dever de transparência, indo além das fases contratuais para alcançar a atividade de planejamento estatal, exigindo que os estudos estratégicos sejam abertos ao conhecimento e à participação social;

- A moralidade repercute sobre todos os aspectos do contrato de colaboração, exigindo que a parceria seja conduzida no sentido da melhor realização do específico interesse público que deveria atender, impedindo o desvio de finalidade, a ausência de finalidade e a ineficiência grosseira ${ }^{88}$

Ainda por se tratar de instrumento de fomento público, os recursos públicos repassados através dos contratos de colaboração não ostentam a natureza de contraprestação, não se tratando de remuneração pelos serviços sociais desenvolvidos. É por isso que, mesmo após transferidos ao parceiro privado, eles manterão a sua natureza jurídica pública, sujeitando-se, por conseguinte, aos chamados princípios de proteção do patrimônio público, notadamente aos da finalidade, transparência, impessoalidade, economicidade e controle, na perspectiva do chamado new public management ${ }^{89}$.

É justamente esse o entendimento de Maria Sylvia Zanella DI PIETRO (2011, p. 282), que, ao examinar os termos de parceria disciplinados pela Lei Federal no 9.790/1999, precisa que:

[...] a verba que o Poder Público repassa à entidade privada não tem natureza de preço ou remuneração, razão pela qual não passa a integrar o patrimônio da entidade, para que ela a utilize a seu bel-prazer, mas, ao contrário, mantém a natureza de dinheiro público; em decorrência disso, a entidade está obrigada a

\footnotetext{
${ }^{88}$ Diogo de Figueiredo MOREIRA NETO (2014, p. 102-103) ensina que, "para que o administrador vulnere este princípio [o da moralidade administrativa], basta que administre mal os interesses públicos, o que poderá ocorrer basicamente de três modos: $10^{\circ}$ - através de atos com desvio de finalidade pública, para perseguir interesses que não são aqueles para os quais deve agir; $2 .^{\circ}$ - através de atos sem finalidade pública $; 3^{\circ}$ - através de atos com deficiência de finalidade pública, reveladores de uma ineficiência grosseira no trato dos interesses que lhe foram afetos (itálicos no original). A noção da moralidade administrativa está, portanto, intimamente ligada com a de finalidade pública, exigindo que a gestão dos bens coletivos [não apenas afeta ao aparato estatal] esteja permanentemente vinculada

${ }^{89}$ De acordo com Humberto Falcão MARTINS (2005, p. 01-02), o new public management corresponde ao novo paradigma de gestão pública que se firmou a partir da crise e reforma do Estado iniciadas na década de 1980, pautado no reordenamento institucional entre os domínios do estado, mercado e terceiro setor, maior flexibilidade de meios, ênfase em resultados, foco no cliente-cidadão e transparência e cobrança de resultados (accountability ou responsividade).
} 
prestar contas de maneira a demonstrar que os recursos foram utilizados para os fins estabelecidos no acordo, sob pena de ilegalidade.

Nessa mesma perspectiva, defendendo a manutenção da natureza pública dos recursos transferidos pelo Estado às entidades da sociedade civil sem fins lucrativos, Marcia PELEGRINI (2007, p. 63) acrescenta que "a própria Constituição deixa claro que estarão tais entidades, como qualquer pessoa física ou jurídica que utilize, arrecade, guarde, gerencie ou administre dinheiro público, submetidas ao controle pelos Tribunal de Contas (art. 70, parágrafo único).

Registre-se, contudo, a existência de pensamento diametralmente oposto, partidário da privatização dos recursos públicos ao serem repassados às entidades não estatais em razão de contrato de colaboração. É a posição de Carlos Ari SUNDFELD e Rodrigo Pagani de SOUZA (2011, p. 61-63), segundo os quais, no contexto da chamado modelo gerencial de gestão ${ }^{90}$, "os recursos financeiros estatais, uma vez transferidos ao parceiro não estatal, tornam-se privados", por duas razões: (i) pelo caráter contraprestacional da avença, em que os recursos são trespassados não para que o parceiro privado os administre e aplique como se Estado fosse, gerenciando orçamento público, independentemente de contrapartidas, senão enquanto contraprestação pelos serviços [sociais] prestados; e (ii) porque essas modernas parcerias estão enfaticamente voltadas ao alcance de resultados, tornando sem sentido a exigência de que as entidades não estatais se comportem como repartição pública na gestão de recursos e na prestação de contas, devendo-se reconhecer ao parceiro privado flexibilidade na gestão dos recursos, mobilizando-os conforme se faça necessário para o atingimento dos objetivos traçados ${ }^{91}$.

Esses Autores (2011, p. 64-67) defendem ainda que a natureza privada dos recursos estatais transferidos não resta abalada nem quando presentes as cláusulas de "devolução dos

\footnotetext{
90 Examinando a gestão dos recursos públicos transferidos nas parcerias celebradas entre o Estado e as entidades privadas sem fins lucrativos, Carlos Ari SUNDFELD e Rodrigo Pagani de SOUZA (2013, p. 63) contrapõem o modelo burocrático de gestão, focado na execução do orçamento a qualquer custo, inclusive em prejuízo dos melhores resultados, com o modelo gerencial de gestão, centrado no alcance dos objetivos e metas públicas.

91 Esse também é o pensamento de Fernando Borges MÂNICA e Fernando MENEGAT (2013, p. 16) especificamente em relação ao contrato de gestão, eis que os repasses de verbas públicas nele envolvidos não teriam natureza de transferência voluntária tal qual previsto no art. 25 da Lei Federal Complementar $\mathrm{n}^{\mathrm{o}}$ 101/2000 e art. 12 da Lei Federal no 4.320/1964, mas, sim, de pagamento a título de contraprestação pelos serviços de gestão prestados pela OS parceira. Para os Autores, o contrato de gestão não tem por objeto o incentivo de atividades privadas [sem reserva de exclusividade estatal] dotadas de relevância pública, senão a transferência da gestão de tais atividades a uma entidade privada qualificada como OS. Não seria o contrato de gestão, portanto, instrumento congênere ao convênio.
} 
recursos recebidos e não utilizados" e de "obrigação de prestação de contas de todas e cada uma das despesas executadas", uma vez que: no primeiro caso, essa restituição somente ocorreria de fato quando diante da inexecução parcial do objeto contratado, não podendo o parceiro privado ficar com o numerário entregue pelo Poder Público justamente para não enriquecer ilicitamente, exatamente como ocorre nos contratos administrativos em geral ${ }^{92}$; e, no segundo, a prestação de contas de cada despesa executada tem o único sentido de propiciar informações relevantes ao Estado sobre a execução do ajuste, conferindo-lhe uma noção da realidade de custos e reduzindo a assimetria de informações entre os contratantes, não se confundindo com ato de gestão de recursos públicos ${ }^{93}$.

Com todas as vênias merecidas, ousamos discordar dessa visão libertária dos eminentes Autores: a uma, porque os recursos estatais repassados não representam qualquer contraprestação, não estando referenciados equivalentemente pelas atividades desenvolvidas pelos entes de colaboração, tratando-se de legítimos mecanismos de fomento, atrelados que estão aos fins sociais fixados no instrumento de parceria; e, a duas, por não haver qualquer incompatibilidade entre o controle de resultados e o controle de meios - ainda que se priorize o primeiro no modelo gerencial de gestão de recursos públicos -, devendo a flexibilidade típica do regime jurídico privatístico das entidades não estatais - também presente, mesmo que com maiores restrições, no seio da própria Administração Pública, hoje orientada pelo paradigma gerencial de organização e funcionamento - ser derrogada pelos deveres e limitações publicísticas fixados em nosso ordenamento jurídico, observando especialmente os princípios constitucionais da isonomia, impessoalidade, publicidade, moralidade e eficiência, jamais infensa aos órgãos administrativos de controle ${ }^{94}$.

Anote-se, inclusive, que a manutenção da natureza pública dos recursos repassados às entidades de direito privado está prevista expressamente no nosso texto constitucional, nomeadamente no inciso II do art. 74 da Lei Maior de 1988, de acordo com o qual incumbe ao TCU comprovar a legalidade e avaliar os resultados, quanto à eficácia e eficiência, da

\footnotetext{
92 [Supostamente] fundamentando a natureza contraprestacional dos recursos públicos transferidos, eles chamam a atenção para o fato do parceiro privado não ter direito a receber mais dinheiro do que o convencionado simplesmente porque necessitará de mais para realizar os objetivos estabelecidos, sendo preciso, se for o caso, conforme o interesse da Administração [público], o aditamento do pacto, aumentandose o seu objeto e, consequentemente, o volume dos valores a serem recebidos em contraprestação, tal qual ocorre com qualquer contrato administrativo.

${ }^{93}$ Ressalve-se que os Autores não negam o dever de prestação de contas do dispêndio dos recursos públicos transferidos em razão da parceria, apenas considerando que ela segue a lógica finalística, simplesmente verificando se as metas e resultados definidos foram atendidos.

${ }^{94} \mathrm{O}$ regime jurídico do controle dos contratos administrativos vem tratado em capítulo na segunda parte desta dissertação.
} 
aplicação de recursos públicos por entidades de direito privado. Em complemento, o par. único do art. 70 da atual Constituição Federal Brasileira expressamente submete à fiscalização da Corte de Contas toda e qualquer pessoa física ou jurídica que gerencie ou administre recursos públicos. Tudo isso reforça a tese de que os contratos de colaboração envolvem verdadeira gestão privada de recursos públicos, que, embora não se confunda com mera colaboração privada com a gestão estatal de recursos públicos, não chega a ser uma gestão privada de recursos privados ${ }^{95}$.

Sem avançar muito no regime jurídico dos contratos de colaboração, aplicando-se as diretrizes da gestão pública ao funcionamento das parcerias sociais entre os setores público e privado aqui examinadas, com repercussões diretas na aplicação dos recursos públicos destinados, verificamos que:

- em nome do princípio da finalidade, os recursos repassados estarão vinculados ao melhor atendimento dos fins sociais traçados;

- por causa da impessoalidade e economicidade, a aquisição de bens e serviços com os recursos públicos transferidos devem seguir regras objetivas de escolha, sempre respeitados os valores praticados no mercado;

- e pela transparência e controle, a aplicação dos recursos públicos transferidos estará sujeita aos sistemas de controle interno e externo da Administração Pública, assim como à fiscalização dos órgãos instituídos no âmbito da própria parceria e ao controle social.

\footnotetext{
${ }^{95}$ Ao contrário do suscitado por SUNDFELD e SOUZA (2013, p. 64), essas duas últimas não são as únicas formas de se encarar a gestão dos recursos repassados no seio das parcerias sociais celebradas entre o Estado e as entidades privadas sem fins lucrativos, existindo também a aqui defendida gestão privada de recursos públicos.
} 


\section{DA NATUREZA JURÍDICA DAS PARTES}

No plano subjetivo, o contrato de colaboração envolve, dum lado, o Estado, que busca por meio da sua Administração Pública entidades da sociedade civil aptas a com ele colaborar na prestação dos serviços sociais; e, doutro, organizações não estatais sem fins lucrativos, que, vocacionadas ao atendimento das necessidades coletivas, se predispõem a firmar parceria com o Poder Público a fim de obter recursos para a melhor realização da sua finalidade institucional de interesse público.

A presença do Estado num dos polos do contrato de colaboração exige que toda a sua ação de fomento esteja pautada pela consecução dos objetivos públicos que legitimam o estímulo oficial a atividades não estatais de relevância coletiva ${ }^{96}$. Nessa medida, enquanto instrumento de realização dos interesses públicos, possuindo dever de garantia do atendimento das necessidades sociais, cabe ao Estado assegurar o cumprimento das metas traçadas no instrumento colaborativo, inclusive diante da inexecução dos serviços por parte do parceiro privado.

Ademais, sendo a Administração Pública uma das contratantes, aplicam-se-lhe todos os princípios constitucionais administrativos, especialmente aqueles contidos no caput do art. 37 da Constituição Federal de 1988, de modo que a sua atuação deve seguir os ditames da lei, ser impessoal, segundo a moralidade administrativa, transparente e eficiente.

Por sua vez, a participação de pessoas não estatais de direito privado na relação colaborativa impõe, consoante defende Paula Raccanello STORTO (2013, p. 363-369), o respeito à liberdade de criação, organização, funcionamento e extinção dessas entidades, como um imperativo da sua autonomia privada e das garantias constitucionais da liberdade de associação e de auto-organização associativa, por se tratarem de entidades típicas de uma sociedade civil organizada que atuam de forma crítica e independente na realização dos interesses públicos e da democracia participativa.

A grande dificuldade no estudo das partes dos contratos de colaboração reside justamente na definição do universo de pessoas jurídicas não estatais sem fins lucrativos

\footnotetext{
${ }^{96}$ Analisando o controle dos mecanismos de fomento, Marcos Juruena Villela SOUTO (2007, p. 34) anota que um dos elementos a ser aferido é a legitimidade dos benefícios outorgados, a se exigir justamente que, com base na lei de diretrizes do planejamento e no respectivo plano de incentivo (art. 174, da Constituição), haja vinculação entre os favores outorgados e um interesse global previamente estabelecido, sob pena de se caracterizar privilégio ou discriminação repudiados pelo princípio constitucional da isonomia (art. $5^{\circ}$ ).
} 
idôneas ao emparceiramento com o Estado para o desenvolvimento [fomentado] de atividades sociais, especialmente diante da inexistência de uniformidade terminológica em nosso ordenamento jurídico ${ }^{97}$.

Dessa forma, o presente capítulo objetiva precisar a noção de entidades não estatais sem fins lucrativos, compulsando as principais construções teóricas que surgiram na doutrina brasileira especializada ao longo dos anos, nomeadamente perquirindo a adequação dos conceitos de entidades paraestatais, terceiro setor e, mais recentemente, organizações da sociedade civil.

A fim de delimitar o elemento subjetivo dos contratos de colaboração examinados no presente trabalho, entendemos que a opção por uma dessas três expressões deve ser capaz justamente de abranger todas aquelas pessoas jurídicas que compartilhem das características indispensáveis à colaboração com o Estado no campo dos serviços sociais, assegurando a exclusão daquelas entidades inidôneas ao recebimento do fomento estatal, por não estarem vinculadas a finalidades de interesse público/de realização do bem comum.

Sem prejuízo, independentemente da locução utilizada para designar as entidades aptas a firmar parcerias com o Estado no setor social, deve-se sempre ter em vista aquilo que essas organizações realmente são $^{98}$, vale dizer, o fato de se tratar de pessoa jurídicas não estatais de direito privado, sem fins lucrativos e vocacionadas ao atendimento das necessidades coletivas.

Valendo-se dos critérios apresentados no Handbook on Non-Profit Institutions in the System of National Accounts (Manual sobre as Instituições sem Fins Lucrativos no Sistema de Contas Nacionais) para o enquadramento de organizações da sociedade civil como instituições sem fins lucrativos, um estudo realizado em parceria pelo IBGE - Instituto Brasileiro de Geografia e Estatística, IPEA - Instituto de Pesquisa Econômica Aplicada, ABONG - Associação Brasileira de Organizações Não Governamentais e GIFE - Grupo de Institutos, Fundações e Empresas em 2005 (reeditado em 2010) resume as características das chamadas FASFIL - Fundações Privadas e Associações sem Fins Lucrativos, aplicáveis às

\footnotetext{
${ }^{97}$ A começar pela Constituição Federal Brasileira, que, como bem adverte Paulo Eduardo Garrido MODESTO (2011, p. 11), se vale das mais variadas expressões, a saber: instituição de educação e de assistência social, sem fins lucrativos (art. 150, VI, c); entidades filantrópicas (art. 199, § $1^{\circ}$ ); entidades sem fins lucrativos (art. $199, \S 1^{\circ}$ ); entidades beneficentes (art. 204, I); e entidades não governamentais (art. 227, $\S 1^{\circ}$ ).

${ }^{98}$ Embora não se negue que as classificações, como formas artificiais de organização do pensamento, são úteis à boa compreensão das características comuns das coisas, racionalizando o conhecimento humano e, no Direito, permitindo um tratamento jurídico uniforme, impende reconhecer que o cientista jamais delas pode se tornar escravo, cabendo-lhe utilizá-las ou não conforme o caso, pois, "para além dos rótulos, o mais importante é compreender realmente sobre o que se está tratando" (Durval CARNEIRO NETO, 2010, 278-279).
} 
entidades não estatais que consideramos aptas a firmarem contratos de colaboração ${ }^{99}$ : (i) privadas, não integram o aparelho estatal; (ii) sem fins lucrativos, não distribuem eventuais excedentes entre proprietários ou diretores e que não possuem como razão primeira de existência a geração de lucros; (iii) institucionalizadas, instituem-se nos termos da lei brasileira; (iv) autoadministradas, são capazes de gerenciar as suas próprias atividades; e (v) voluntárias, podem ser constituídas livremente por qualquer grupo de pessoas (IBGE, 2012) ${ }^{100}$.

De acordo com esse estudo, os referidos critérios conduzem, no caso brasileiro, às figuras jurídicas das associações, fundações e organizações religiosas ${ }^{101}$, não abrangendo aquelas entidades que, embora sem fins lucrativos, careçam de alguma das demais características (privadas, institucionalizadas, autoadministradas e voluntárias), a exemplo do serviço social autônomo, do partido político e da fundação ou associação domiciliada no exterior.

Enquanto pessoas jurídicas não estatais de direito privado, elas não se inserem na noção de Administração Pública em sentido subjetivo ou de Administração Pública Estatal (Marçal JUSTEN FILHO, 2013, p. 326) ${ }^{102}$, não estando submetidas, ao menos em princípio, ao conjunto de prerrogativas e restrições especiais do Direito Público, não incidindo, no que diz respeito à entidade em si, a legalidade administrativa, a impessoalidade, a publicidade $\mathrm{e}$ a presunção de legitimidade e veracidade dos seus atos. A sua criação, organização, funcionamento e extinção se orientam, por conseguinte, pelo princípio da autonomia privada, não se admitindo que a sua instituição seja dependente de algum esforço oficial nem

\footnotetext{
${ }^{99} \mathrm{Na}$ verdade, os critérios elencados pela ONU não levam em conta a exigência de finalidade social da entidade, de atendimento das necessidades da coletividade, o que não se compatibiliza com o presente trabalho. É que, como será melhor explicitado, não se legitimam à celebração de contratos de colaboração aquelas pessoas jurídicas não estatais sem fins lucrativos que oferecem benefícios a um núcleo restrito de pessoas, de caráter corporativo.

${ }^{100}$ Esse estudo observa que, em 2010, existia um total de 556,8 mil pessoas jurídicas cadastradas no Cadastro Central de Empresas - CEMPRE do IBGE como entidades sem fins lucrativos, e que, após a exclusão daquelas que não atendem às cinco características exigidas pela ONU (e aceitas pelo estudo) para o enquadramento como instituições sem fins lucrativos (ou, como prefere o estudo: FASFIL - Fundações Privadas e Associações sem Fins Lucrativos), restavam apenas 290,7 mil organizações.

${ }^{101}$ Conforme se exporá, todavia, não incluímos as organizações religiosas entre aquelas entidades legitimadas à celebração de contratos de colaboração, porquanto, embora a Constituição Federal de 1988 admita no inciso I do seu art. 19 o fomento estatal a essas entidades ("cooperação de interesse público"), elas não possuem finalidade precípua de atendimento à comunidade, desnaturando o vínculo colaborativo, sujeitando-se a regime jurídico próprio.

${ }^{102}$ De acordo com Maria Sylvia Zanella DI PIETRO (2012, p. 58-59), "pode-se definir Administração Pública, em sentido subjetivo, como o conjunto de órgãos e de pessoas jurídicas aos quais a lei atribui o exercício da função administrativa do Estado", abrangendo a Administração Direta (União, Estados, Municípios e Distrito Federal) e a Indireta (autarquias, empresas públicas, sociedades de economia mista, fundações e os consórcios públicos).
} 
que a sua gestão recaia nas mãos do Poder Público, sob pena de se sacrificar a garantia constitucional da liberdade de associação e de transformar a entidade em verdadeiro braço governamental na execução de políticas públicas, dissimulação que visa tão somente à fuga ilegítima do regime jurídico administrativo, inaceitável à luz dos ditames constitucionais ${ }^{103}$.

A finalidade não lucrativa é imperativo diretamente relacionado com a natureza instrumental do Estado de proteção e persecução dos interesses públicos ${ }^{104}$, pois, enquanto ferramenta da sociedade para o atendimento das necessidades coletivas, o Estado somente está autorizado a aportar recursos públicos em atividades de relevância social prestadas sem intuito de lucro, fora da lógica de mercado. Não é por acaso que a própria Constituição Federal exige a finalidade não lucrativa para o recebimento de recursos públicos por entidades não estatais de saúde (art. 199, § 2º ) e de educação (art. 213), regra esta que, numa interpretação lógico-sistemática do texto constitucional, acaba por se generalizar para todo e qualquer setor social ${ }^{105}$.

Nada impede, contudo, a parceria do Poder Público com sociedades privadas, pessoas jurídicas não estatais com finalidade lucrativa, para a consecução de objetivos de interesse público (desenvolvimento econômico e fomento do emprego numa dada região, proteção ao meio ambiente, programas de inovação tecnológica, etc.), desde que a cooperação com essas entidades não implique a transferência de recursos financeiros. É o caso, por exemplo, dos termos de reciprocidade celebrados pelo Instituto Chico Mendes de Conservação da Biodiversidade - ICMBIO e "órgãos ou entidades da administração pública federal, estadual, distrital ou municipal, direta ou indireta, ou ainda, entidades privadas com ou sem fins lucrativos, visando a execução de projetos, atividades ou quaisquer eventos de interesse recíproco, com previsão de contratação de serviços e aquisição de bens, em regime de mútua cooperação, não havendo transferências de recursos financeiros originários de

\footnotetext{
${ }^{103}$ Comentando os critérios propostos pela COPNI - Classification of the Purpose of Non-Profit Institutions Serving Households, da Organizações das Nações Unidas, para a definição das organizações da sociedade civil, Paula Raccanello STORTO (2013, p. 365) afirma se destacar justamente o seu caráter essencialmente privado, que tem como premissa o fato de serem voluntárias e autoadministradas.

${ }^{104}$ Nessa perspectiva instrumental de Estado, Luís Jordana de POZAS (1949, p. 41) ensina que a ação administrativa tem como finalidade geral satisfazer necessidades públicas, poucas das quais são universais e constantes, muitas variando normalmente com a cultura.

105 É Paulo Eduardo Garrido MODESTO (2011, p. 11) quem observa que o art. 213 da Constituição Federal acaba por oferecer uma definição implícita de entidade privada sem fins lucrativos de caráter público, fixando dois predicados essenciais para o recebimento de recursos públicos por essas entidades: aplicação dos excedentes financeiros na própria atividade institucional de natureza social (proibição de partilha do resultado social); e destinação do patrimônio social a outra entidade de mesma natureza ou ao Poder Público em caso de extinção (proibição de partilha do patrimônio social).
} 
dotações do ICMBIO consignadas nos Orçamentos Fiscal e da Seguridade Social da União" [Grifos nossos] (ICMBIO, 2009, p. 01).

Gustavo Justino de OLIVEIRA (2007b, p. 30) alerta que o sentido jurídico da expressão sem fins lucrativos não é unívoco em nosso ordenamento, existindo diferenças, por exemplo, entre aquele do Código Tributário Nacional, o da Lei Federal nº 9.249/1995, o da Lei Federal no 9.790/1999 e o da Lei Federal n 10.101/00. Parece-nos acertado, todavia, o entendimento de Francisco de Assis ALVES (2006, p. 218) segundo o qual a locução sem fins lucrativos deve ser tomada no mesmo significado dado pelo art. 150, VI, $c$, da CF, como requisito para a imunidade tributária.

De acordo com o art. $2^{\circ}$ do Anteprojeto de Lei de Estatuto do Terceiro Setor proposto pelo Relatório Estatuto Jurídico do Terceiro Setor: pertinência, conteúdo e possibilidades de configuração normativa ${ }^{106}$, considera-se pessoa jurídica de direito privado sem fins lucrativos aquela entidade que "não distribui, entre seus sócios ou associados, conselheiros, diretores, empregados, doadores ou fundadores, eventuais excedentes operacionais, brutos ou líquidos, dividendos, bonificações, participações ou parcelas do seu patrimônio, auferidos mediante o exercício de suas atividades, e que os aplica integralmente na consecução do respectivo objetivo social".

Em sentido semelhante, o art. $2^{\circ}$, I, da recente Lei Federal n ${ }^{\circ} 13.019 / 2014$ - Lei de Parcerias Sociais estabelece ser pessoa jurídica de direito privado sem fins lucrativos aquela que:

[...] não distribui, entre os seus sócios ou associados, conselheiros, diretores, empregados ou doadores, eventuais resultados, sobras, excedentes operacionais, brutos ou líquidos, dividendos, bonificações, participações ou parcelas do seu patrimônio, auferidos mediante o exercício de suas atividades, e que os aplica integralmente na consecução do respectivo objeto social, de forma imediata ou por meio da constituição de fundo patrimonial ou fundo de reserva ${ }^{107}$.

\footnotetext{
106 Apresentado pelo Instituto Pro Bono em 2009, trata-se de trabalho desenvolvido sob a coordenação do Professor Gustavo Justino de Oliveira para o Projeto Pensando o Direito, da Secretaria de Assuntos Legislativos do Ministério da Justiça em parceria com o Programa das Nações Unidas para o Desenvolvimento - PNUD, e que contém minucioso estudo sobre as formas jurídicas possíveis das entidades do Terceiro Setor, dos títulos e certificações estatais outorgáveis, da sua fiscalização e controle pelo Poder Público e das parcerias admitidas com o Estado, no Brasil e no Direito Comparado, buscando o delineamento dum regime jurídico mínimo comum para as entidades do terceiro setor.

${ }^{107}$ Nesse mesmo diapasão: art. 2 ${ }^{\circ}$, I, "h" e “i”, da Lei Federal no 9.637/1998; e art. $1^{\circ}, \S 1^{\circ}$, da Lei Federal no 9.790/1999 (Lei das OSCIPs).
} 
Impende notar, contudo, que a finalidade não lucrativa não se desnatura pela cobrança de contraprestação financeira dos beneficiários dos serviços sociais prestados, bastando para tanto que o valor cobrado seja integralmente destinado ao custeio dos seus objetivos sociais, de forma alguma repartindo-se os excedentes financeiros entre os seus diretores, associados, empregados ou colaboradores. Em outras palavras, a finalidade não lucrativa não obriga, ao menos em princípio, à adoção do regime de gratuidade (Sílvio Luís Ferreira da ROCHA, 2006, p. 117).

Da mesma forma, é de se admitir que essas entidades desenvolvam, de forma complementar, sem descaracterizar a sua finalidade não lucrativa, atividades econômicas de produção de bens e serviços para o comércio ou a indústria ${ }^{108}$, exigindo-se apenas que os superávits obtidos sejam revertidos à manutenção da sua finalidade principal de caráter social. É exatamente esse o entendimento encampado pelo $\S 1^{\circ}$ do art. 10 do referido Anteprojeto de Terceiro Setor, de acordo com o qual a prestação de atividades econômicas pelo terceiro setor ${ }^{109}$ dependerá da satisfação cumulativa das seguintes condições: as atividades econômicas não constituam objeto ou finalidade principal da entidade; as atividades econômicas guardem relação com o objeto ou finalidade principal da entidade; as atividades econômicas constituam forma de apoiar e subsidiar o objeto ou finalidade principal da entidade; ao menos $80 \%$ (oitenta por cento) dos resultados econômicos auferidos pelo desenvolvimento de atividades econômicas revertam para o objeto ou finalidade principal da entidade, admitindo-se que o restante seja aplicado em fundo financeiro especial, exclusivamente destinado a garantir a sustentabilidade da entidade ${ }^{110}$.

Nessa toada, preocupado com o financiamento das entidades da sociedade civil sem fins lucrativos e a realização dos seus objetivos sociais, Fernando Magalhães MODÉ (2008, p. 221-227) explica a possibilidade de aplicação dos excedentes financeiros das entidades não estatais sem fins lucrativos em fundos financeiros ou endowments de baixo risco (a exemplo dos títulos do tesouro nacional ou Cédulas de Depósito Bancário), importante instrumento de combate à escassez de recursos. A par da importância para a sustentabilidade econômica dessas entidades, esses fundos financeiros também se prestariam a dois outros

\footnotetext{
${ }^{108} \mathrm{O}$ conceito de atividades econômicas e as suas classificações serão abordados em momento mais adequado neste trabalho.

${ }^{109}$ A noção de terceiro setor será melhor trabalhada na sequência, quando demonstraremos as dificuldades em lhe precisar um conteúdo no âmbito do Direito e os motivos pelos quais preferimos não utilizá-la.

110 A nota explicativa deste dispositivo do Anteprojeto chama a atenção para o fato de o próprio Supremo Tribunal Federal, no julgamento dos Emb. Div. no RE $n^{\circ} 210.251-2$, ter reconhecido às entidades assistenciais o direito de aplicar parte do dinheiro obtido com o desenvolvimento de atividades econômicas em fundos financeiros especialmente destinados à sua manutenção.
} 
objetivos igualmente importantes para aquelas organizações que firmem convênios e desenvolvam projetos comuns com outras instituições privadas ou mesmo com o Estado: demonstração da sua capacidade de realização e governança; e garantia de eventuais contrapartidas financeiras que se façam necessárias ${ }^{111}$.

Finalmente, somente as pessoas jurídicas sem fins lucrativos que se destinem ao atendimento das necessidades da coletividade, oferecendo comodidades ou utilidades a todo o corpo social, são idôneas à celebração de contratos de colaboração com o Estado e, por consequência, ao recebimento de recursos públicos para a consecução dos seus fins sociais.

Aqui, cumpre distinguir as chamadas entidades de favorecimento mútuo ou de fins mútuos daquelas de fins comunitários, públicos ou de solidariedade social. De acordo com Paulo Eduardo Garrido MODESTO (2006, p. 06), enquanto as primeiras estão “dirigidas a proporcionar benefícios a um círculo restrito ou limitado de associados, inclusive mediante a cobrança de contribuições em dinheiro, facultativas ou compulsórias”, não servindo desinteressadamente à coletividade [v.g., os serviços sociais autônomos], as segundas visam a "oferecer utilidades concretas ou benefícios especiais à comunidade de um modo geral, sem atentar para vínculos especiais, quase sempre de forma gratuita"112.

Assim sendo, por desenvolverem atividade endógena de defesa de interesses setoriais ou grupais, voltando-se ao chamado espaço corporativo (Luiz Carlos BRESSER PEREIRA e Nuria CUNILLL GRAU, 1999, p. 21), entendemos que os tradicionais serviços sociais autônomos (Sistema $S$ ) não estão aptos a celebrar com o Estado contrato de colaboração, na medida em que este instrumentaliza parceria social entre os setores público e privado em prol do bem-estar de todos e da realização da justiça social, não se confundindo com o oferecimento de utilidades materiais a um círculo restrito de pessoas.

A exigência dessa vocação para a coletividade decorre do já referido papel instrumental do Estado, cuja atuação se orienta pela realização dos interesses públicos, em

\footnotetext{
${ }^{111}$ O Autor (2008, p. 226-227) explica que a viabilização da cooperação entre as organizações da sociedade civil sem fins lucrativos e outras instituições estatais e não estatais pode ser bastante facilitada pela existência de um fundo patrimonial, que denota, dentre outras coisas, que a entidade titular deste fundo tem um nível diferenciado de eficácia de sua estrutura de governança e que, além de uma boa estrutura de governança, possui capacidade financeira para a realização das ações que propõe realizar via acordo de cooperação.

112 Paulo Eduardo Garrido MODESTO (2006, p. 06) observa, ainda, que a ausência de tal diferenciação combinada com a debilidade do sistema de controle de resultados legalmente previsto, que se satisfaz com a apresentação periódica de documentos - foi determinante para a crise do título de utilidade pública instituído no âmbito federal pela Lei Federal $n^{\circ}$ 91/1935, abrindo margem para abusos, fomentando, assim, a desconfiança em atividades e relações de parceria entre os setores público e privado, em que a confiança e probidade são valores fundamentais.,
} 
atendimento às necessidades dos cidadãos. Obviamente, nada impede que a Administração Pública fomente atividades econômicas em sentido estrito desenvolvidas pela iniciativa privada de fins lucrativos, desde que assim atue com vistas à obtenção das já aludidas externalidades positivas. De todo modo, a exclusão do fomento à iniciativa privada de fins lucrativos aqui se justifica por ele se submeter a regime jurídico próprio, sensivelmente distinto daquele dos contratos de colaboração, que se prestam ao estímulo direto de atividades sociais, imediata e essencialmente relacionadas com $\mathrm{o}$ atendimento das necessidades da coletividade.

Enfim, é reconhecendo que somente aquelas pessoas jurídicas de direito privado sem fins lucrativos que se voltem à realização dos interesses públicos estão aptas à celebração dos contratos de colaboração estudados nesse trabalho - e considerando as ponderações aqui feitas acerca das suas características essenciais - que passamos ao exame das principais expressões utilizadas para designar essas entidades parceiras do Estado nos serviços sociais.

\subsection{Das Entidades Paraestatais}

Anotando a origem italiana da expressão entidades paraestatais (Decreto-lei Real de 1924) e a grande imprecisão que sempre permeou o seu conceito naquele país (e assim foi trazida para o nosso pelos doutrinadores nacionais), Celso Antônio Bandeira de MELLO (2009, p. 157-159) afirma que, entre os doutrinadores brasileiros, houve aqueles que as entendiam como "espécie de autarquia com fortes laços de dependência do Estado" (Miguel REALE e Oscar SARAIVA); outros que, ao contrário, as correspondiam a "autarquias que se ligam ao Estado por vínculos pouco estritos (Temístocles CAVALCANTI); e aqueles que, conquanto as enquadrassem como autarquias, defendiam ser pessoas de natureza privada, constituindo-se como "forma de colaboração dos particulares com a Administração" (Rui de SOUZA). De acordo com o Autor, entretanto, o ponto de vista que ganhou maior difusão entre nós foi o expendido por Hely Lopes MEIRELLES, o qual, segundo pensa, se apresentaria inaceitável no Direito Brasileiro, já que reuniria tanto entidades integrantes da Administração Pública, nomeadamente as sociedades de economia mista e empresas públicas, quanto entes não estatais, quais sejam os chamados serviços sociais autônomos. 
Diante da inexistência dum conceito legal de entidades paraestatais e da inexatidão que marcou a sua origem no Direito Italiano, Alice Gonzalez BORGES (2011, p. 02) ensina que não se formou na doutrina brasileira consenso quanto à abrangência da expressão, ora se incluindo as entidades da Administração Indireta que são regidas pelo direito privado, ora se colocando na definição o chamado terceiro setor, figurando com unanimidade entre os autores nacionais apenas os serviços sociais autônomos.

Marçal JUSTEN FILHO (2013, p. 322), por exemplo, limita a noção de entidades paraestatais aos serviços sociais autônomos, afirmando que "Entidade paraestatal ou serviço social autônomo é uma pessoa jurídica de direito privado criada por lei para, atuando sem submissão à Administração Pública, promover o atendimento de necessidades assistenciais e educacionais de certas atividades ou categorias profissionais, que arcam com sua manutenção mediante contribuições compulsórias"113.

Esses serviços sociais autônomos correspondem: (i) ao tradicional Sistema S, cuja criação é autorizada por lei e o seu regulamento aprovado pelo Chefe do Poder Executivo, a exemplo do Serviço Social da Indústria - SESI, do Serviço Nacional de Aprendizagem Industrial - SENAI e do Serviço Social do Comércio - SESC; e, (ii) mais recentemente, a entidades criadas diretamente (e assim intituladas) por lei para a prestação de atividades de interesse público, como é o caso da Agência de Promoção de Exportações do Brasil - APEXBrasil, da Agência Brasileira de Desenvolvimento Industrial - ABDI e das Associações Pioneiras Sociais - APS ${ }^{114}$.

\footnotetext{
${ }^{113}$ Assim também já concluiu o Superior Tribunal de Justiça, quando, no CComp no ${ }^{\circ}$ 41.246/SC, o Ministro Relator Castro Meira consignou que o SEBRAE, "assim como as demais entidades paraestatais ou entes de cooperação (SESI, SESC, SENAI e outros), tem natureza de pessoa jurídica de direito privado, não integrando a Administração Pública direta ou indireta".

${ }^{114}$ Alice Gonzalez BORGES (2011, p. 08-09; 13) destaca a existência de dois tipos de serviços sociais autônomos em nosso ordenamento jurídico: (i) os ditos clássicos ou originários, cuja criação, iniciada ainda sob a vigência da Constituição de 1946, é autorizada por lei e atribuída às confederações de categorias profissionais ou empresariais, possuindo autonomia em relação à Administração Pública, funcionando como um instrumento de fomento estatal a atividades de interesse público e sendo mantidas, com fundamento no art. 204 da atual Constituição Federal de 1988, por meio de contribuições parafiscais arrecadadas pela própria entidade e por estas geridas; e (ii) aqueles que, sem qualquer previsão constitucional, foram surgindo a partir da década de 1990, sendo criados diretamente pela lei, geralmente mediante a transformação de entidades da Administração Pública Indireta preexistentes, subsistindo por meio de dotações orçamentárias e atuando sem qualquer autonomia de ação em relação ao Poder Público. A Autora observa serem poucos os doutrinadores nacionais que distinguem essas espécies de serviços sociais autônomos, em que pese haver, segundo pensa, clara diferença entre o regime jurídico ao qual estão submetidas, nomeadamente porque o segundo grupo nada mais seria que uma contrafação, um modo de burlar as salutares exigências constitucionais da obrigatoriedade de licitação e da admissão de pessoal mediante concurso. Nessa mesma toada, conclui DI PIETRO (2010, p. 245-246) que, ao ser instituído por lei e viver de dotações orçamentárias do Estado, esse segundo grupo configuraria um desvirtuamento do instituto dos serviços sociais autônomos, já que apresenta praticamente todas as características das entidades da Administração Pública, razão pela qual deveriam se submeter às normas pertinentes da Constituição. Não se pode deixar de consignar, contudo, que o STF, no julgamento da
} 
Para nós, todavia, os serviços sociais autônomos, em quaisquer de suas espécies (autorizados ou criados por lei), não se legitimam à celebração de contratos de colaboração, pois: falta-lhes liberdade de criação, organização e gestão própria da iniciativa privada, na medida em que são autorizados ou criados por lei, inexistindo a autonomia típica das pessoas jurídicas não estatais de direito privado, o que acaba por descaracterizar o regime jurídico de parceria ${ }^{115}$; e não se dirigem ao atendimento das necessidades da coletividade, já que disponibilizam benefícios apenas aos integrantes de determinada categoria empresarial ou profissional, não oferecendo qualquer comodidade ou utilidade à sociedade como um todo, esta que, no máximo, aufere proveitos indiretos com a sua atuação ${ }^{116}$.

Avançando no exame da noção de entidades paraestatais, verificamos a existência de autores que lhe conferem um conceito mais amplo, para além dos serviços sociais autônomos, entendendo-as, de forma mais consentânea com próprio sentido etimológico da expressão, como quaisquer "sujeitos não estatais, isto é, de direito privado, que, em paralelismo com o Estado, desempenham cometimentos que este poderia desempenhar por se encontrarem no âmbito de interesses seus, mas não exclusivamente seus" (Celso Antônio Bandeira de MELLO, 2009, p. 159).

Em sintonia com os ensinamentos de Celso Antônio Bandeira de MELLO, Maria Sylvia Zanella DI PIETRO (2012, p. 550-552) conceitua as entidades paraestatais como:

[...] pessoas de direito privado, instituídas por particulares, com ou sem autorização legislativa, para o desempenho de atividades privadas de interesse

\footnotetext{
$\mathrm{ADI}^{\circ}$ 1.864-9/PR, ao examinar a natureza jurídica da entidade PARANAEDUCAÇÃO (criada como serviço social autônomo diretamente pela Lei Paranaense $\mathrm{n}^{\mathbf{0}} 11.498 / 1996$, reinstituída pela Lei Estadual $\mathrm{n}^{\mathbf{0}}$ 15.211/2006, com o objetivo de desenvolvimento regional, urbano e institucional dos Municípios) simplesmente desconsiderou as diferenças aqui mencionadas e a afirmou compatível com a ordem constitucional, não se lhe aplicando a Lei 8.666/1993 e não se lhe exigindo a realização de concurso público para a contratação, pelo regime celetista, de pessoal. Parece-nos adequado, entretanto, excluir do conceito de entidades paraestatais esses serviços sociais autônomos instituídos diretamente por meio lei, voltados à execução das mais variadas atividades de interesse público e mantidos exclusivamente por verbas orçamentárias. Ocorre que, à luz do inciso XIX do art. 37 da Constituição Federal de 1988, tais entidades não passam de autarquias travestidas, dum verdadeiro simulacro de descentralização (Fernando Facury SCAFF, 2001, p. 287), de mais uma forma de fuga para o direito privado (Maria João ESTORNINHO, 1999) ${ }^{114}$, enfim, de um instrumento ilegítimo de que se vale o Estado para se livrar das restrições do regime jurídico de Direito Público.

${ }^{115} \mathrm{Na}$ esteira do referido estudo desenvolvido em parceria pelo IBGE, IPEA, ABONG e GIFE em 2005 acerca das fundações privadas e associações sem fins lucrativos, Paula Raccanello STORTO (2013, p. 365) também exclui dessa noção toda e qualquer entidade criada por lei ou controlada pelo Poder Público, afastando os serviços sociais autônomos justamente por terem a sua criação dependente de lei.

${ }^{116}$ Não é de se olvidar, contudo, que, ao incentivar as empresas a custearem serviços sociais e de aprendizagem pessoal em favor dos seus empregados, os serviços sociais representam uma verdadeira ferramenta de fomento estatal, produzindo reflexos positivos para a sociedade, que se beneficia da produção de uma mão-de-obra mais qualificada, contribuindo para a geração de novos empregos (Durval Carneiro BORGES, 2011, p. 02-03).
} 
público, mediante fomento e controle pelo Estado", recebendo tal alcunha por serem entidades paralelas à Administração Pública, fora da sua estrutura, mas que colaboram com o Poder Público, recebendo, por este motivo, especial proteção ${ }^{117}$.

Equiparando as entidades paraestatais com a noção de terceiro setor, a Autora (2012, p. 552) afirma que, a despeito das diferenças contidas nas leis específicas que disciplinam algumas dessas entidades, não há dúvida que, do ponto de vista de seus vínculos com o Estado, elas estão na mesma posição e apresentam vários pontos comuns: (i) não são criadas pelo Estado, ainda que algumas delas sejam autorizadas ou dependentes de algum impulso oficial (como os serviços sociais autônomos); (ii) não desempenham, em regra ${ }^{118}$, serviço público delegado pelo Estado, mas atividade privada de interesse público, os chamados serviços sociais não exclusivos do Estado; (iii) recebem algum tipo de incentivo do Poder Público, seja a outorga de um título, auxílio ou subvenção, seja a cessão de servidores ou o uso de bens públicos; (iv) muitas ${ }^{119}$ têm vínculos jurídicos com o Poder Público, por meio de convênio, contrato de gestão, termo de parceria ou outros instrumentos similares; (v) possuem regime jurídico de direito privado derrogado por normas publicísticas, mercê do vínculo que estabelecem [podem estabelecer] com o Estado; e (vi) integram o terceiro setor, porquanto não seriam inteiramente entidades privadas, nem integrariam a Administração Pública, sendo todas organizações não governamentais.

Ainda segundo Maria Sylvia Zanella DI PIETRO (2010b, p. 833), as entidades paraestatais:

[...] estão a meio caminho entre o setor público e o setor privado, entre o direito público e o direito privado, seja pelas atividades que exercem, voltadas para o atendimento de necessidades coletivas, seja pelo vínculo que mantêm com o poder público, que as sujeita a algum tipo de controle não imposto às demais entidades privadas, seja pela submissão parcial a normas de direito público. Todas elas

\footnotetext{
${ }^{117}$ Conquanto Maria Silvia Zanella DI PIETRO (2010, p. 242) inclua na categoria das paraestatais tanto os serviços sociais autônomos quanto as entidades de apoio, as declaradas de utilidade pública, as organizações sociais e as organizações da sociedade civil de interesse público, cumpre reconhecer que ela não ignora o traço diferenciador dos serviços sociais autônomos, qual seja o impulso oficial na sua criação, mediante autorização estatal ou instituição diretamente pela lei. Para ela, a reunião, sob a mesma locução, dos serviços sociais autônomos, das entidades de apoio, e, quando tenham vínculo com o Poder Público, das entidades do terceiro setor, decorre delas estarem sujeitas ao mesmo regime jurídico, qual seja o de Direito Privado derrogado por normas de Direito Público (2012, p. 553).

${ }^{118}$ É a Autora (2012, p. 553) entende que as organizações sociais prestam serviço público social, de titularidade do Estado, transferidos mediante delegação feita por meio do contrato de gestão. Ela associa esta peculiaridade das organizações sociais - qual seja a de, na maioria dos casos, prestarem serviços públicos - ao fato da qualificação ser [supostamente] de iniciativa do Estado, prestarem a atividade com a utilização do patrimônio público e poderem se valer de servidores públicos em seu quadro de pessoal.

${ }^{119}$ Destaque-se que a formação de parcerias com o Estado não é uma característica essencial do Terceiro Setor. Todavia, como se demonstrará a seguir, é indispensável - mas não suficiente - ser uma entidade do Terceiro Setor para celebrar contratos de colaboração com o Poder Público.
} 
atuam ao lado do Estado, em colaboração com ele, sem integrarem a Administração Pública direta ou indireta.

Entendemos adequado o sentido conferido por Celso Antônio Bandeira de MELLO e Maria Sylvia Zanella DI PIETRO às entidades paraestatais, já que reúne sob a mesma locução - e, como dito, em coerência com o sentido etimológico da expressão - organizações privadas de regime jurídico assemelhado, as quais, fora da estrutura da Administração Pública, estão ao lado do Estado na realização de cometimentos sociais de interesse público, podendo agir autonomamente ou com ele celebrar vínculos de parceria. Para nós, é somente nessa acepção que se pode considerar que as paraestatais são entidades que colaboram com o Estado na realização do interesse público, idôneas à celebração de contrato de colaboração nos serviços sociais.

Nada obstante, registre-se que o mencionado Anteprojeto de Reforma da Administração Pública Brasileira considera como entidades paraestatais apenas os serviços sociais autônomos, de personalidade jurídica de direito privado, e, numa perspectiva inovadora, as corporações profissionais, estas que, apesar da sua personalidade jurídica de direito público, não estariam inseridas na estrutura estatal, tratando-se, na contramão da tradição doutrinária brasileira - e, como se demonstrará, do atual arquétipo constitucional engendrado para a Administração Pública -, de público não estatal em sentido orgânico ${ }^{120}$.

De acordo com Durval CARNEIRO NETO (2010, p. 316), o Anteprojeto separou em três grupos as entidades que desempenham atividades administrativas: (i) entidades estatais (Administração Pública Direta e Indireta); (ii) entidades paraestatais (pessoas jurídicas criadas por iniciativa do Estado, mas que não integram a sua estrutura, tanto com

\footnotetext{
${ }^{120}$ Examinando a evolução da disciplina legal e jurisprudencial dos conselhos de fiscalização profissional no Brasil, com vistas a identificar a sua natureza jurídica e o regime jurídico ao qual estão submetidos, Durval CARNEIRO NETO (2010, p. 306-307) afirma que, influenciados pela doutrina italiana das entidades autárquicas, os juristas brasileiros nunca deram muito espaço à ideia de Administração Pública Autônoma, não admitindo a existência de entidades administrativas fora do aparato estatal, somente se considerando Administração Pública em sentido orgânico a Direta e a Indireta, classificação dicotômica inclusive consagrada no caput do art. 37 da Constituição Federal de 1988. De acordo com o Autor, entretanto, o STF já admitiu a existência de pessoa jurídica de direito público fora da Administração Pública Direta e Indireta, justamente quando, no julgamento da ADI no 3.026-4/DF, considerou que a OAB - Ordem dos Advogados do Brasil seria categoria ímpar, pessoa jurídica de direito público de natureza não autárquica plenamente autônoma em relação ao Poder Público, que, fora da sua estrutura orgânica, não se sujeita a qualquer forma de supervisão ministerial e controle pelo Tribunal de Contas da União, estando à margem dos ditames do art. 37 da Constituição Federal, mormente da exigência de concurso público para seleção de pessoal e da realização de licitação para as suas contratações. Ele chama a atenção, ainda, para o voto do Ministro Eros Grau proferido no julgamento do pedido liminar no Mandado de Segurança n ${ }^{\circ}$ 26.150, em 19/09/206, segundo o qual "Os conselhos de físcalização de profissões regulamentadas, assim como a $\mathrm{OAB}$, não constituem autarquias, eis que diferentemente do que ocorre com elas, não estão sujeitos à tutela da Administração Pública" (conforme estabelecido no Decreto-Lei $\mathrm{n}^{\mathrm{o}} 2.299 / 1986$ ).
} 
personalidade jurídica de direito privado quanto com personalidade de direito público); e (iii) e entidades de colaboração (pessoas jurídicas não estatais, sem fins lucrativos, constituídas livremente pela iniciativa privada para o desempenho de atividades de relevância pública).

$\mathrm{Na}$ solução encontrada pelo Anteprojeto para os conselhos de fiscalização profissional, percebemos que, de um lado, a sua colocação fora da estrutura da Administração Pública busca justificar a autonomia maior dessas entidades, as quais, nos termos do Decreto-Lei $\mathrm{n}^{\circ}$ 2.299/1986, não se sujeitam a qualquer forma de supervisão ministerial, e, segundo pretende o Anteprojeto, estariam fora do controle pelo TCU e à margem das regras do concurso público e de licitação; e, do outro, a atribuição da natureza de direito público visa a contornar, como bem decidiu o STF na ADI n ${ }^{\circ}$ 1.717-6/DF, a incompatibilidade da personalidade de direito privado com o exercício de atividades exclusivas ou típicas do Estado, nomeadamente a de polícia, de tributar e de punir $^{121}$.

Ocorre, todavia, que, deixando de lado qualquer apego à aludida tradição doutrinária brasileira, não vislumbramos na Constituição Federal de 1988 a possibilidade de criação de pessoas jurídicas não estatais de direito público. Com efeito, o inciso XIX do art. 37 do texto constitucional estabelece que somente lei específica poderá criar autarquia e autorizar a instituição de empresa pública, de sociedade de economia mista e de fundação (de direito privado), donde se conclui que a criação de entidade diretamente por meio de lei impõe a sua natureza jurídica autárquica (de direito público), que atrai, ao menos em princípio, o regime jurídico administrativo in totum previsto no art. 37 da Constituição Federal, somente compatível com a estrutura estatal ${ }^{122}$.

121 Chamando atenção para o fato de que a teoria das atividades estatais indelegáveis "é impregnada de ideologia, dependendo das concepções pessoais que temos acerca do tamanho ideal do papel do Estado, Fernando Vernalha GUIMARÃES (2013, p. 13) afirma que a Constituição Federal Brasileira não traz regras específicas e explícitas que vedem a transferência (legal ou administrativa) de certas atividades aos privados, limitando-se o texto constitucional a reservar ao monopólio estatal alguns serviços, com interdição de sua prestação pela iniciativa privada. Para ele, é o acolhimento do princípio republicano e do cariz democrático do Estado Brasileiro que impõe a reserva de certas competências envolvidas com o uso da violência e o poder de império, instrumentais à satisfação de valores prezados pelo Estado Democrático de Direito. Explica o Autor que o sistema republicano impõe a reserva de certos poderes nas mãos do Estado com vistas a dotá-lo de condições suficientes para promover os valores e objetivos fundamentais constitucionais, como a soberania, a cidadania, a dignidade da pessoa humana, o progresso, a erradicação da pobreza, ente outros. Nessa mesma linha, Gaspar Arinõ ORTIZ (1993, p. 243) afirma que os atos marcados pelo exercício de autoridade pública são funções da soberania e, assim, constituem o primeiro limite à transferência de atividades à iniciativa privada. Registre-se, nesse trilhar, que o art. 40, I, da novel Lei 13.019/2014 veda a firmatura de termo de colaboração ou de termo de fomento que tenha por objeto a delegação das funções de regulação, de polícia e outras atividades exclusivas do Estado.

${ }^{122}$ Entendemos não haver qualquer incompatibilidade entre a natureza jurídica de pessoa jurídica de direito público dos conselhos de fiscalização profissional - autárquica, na verdade, tendo em vista as prescrições do 
E nem se diga que a solução encontrada pelo STF na referida ADI n 3.026-4/DF para a $\mathrm{OAB}$ corrobora a possibilidade de pessoas jurídicas de direito público fora da estrutura da Administração Pública. Ocorre que esta entidade possui previsão também constitucional, estando delineada em nossa Lei Maior enquanto uma entidade própria, com funções institucionais para muito além da mera fiscalização de atividade profissional, tratando-se, nas palavras da ementa do aludido julgado, de um "serviço público independente, categoria jurídica ímpar no elenco das personalidades jurídicas existentes no direito brasileiro" ${ }^{123}$.

Sem mais digressões, concluímos que, diante da inexistência dum conceito legal de entidades paraestatais, a doutrina e a jurisprudência nacionais estão longe de chegar a um consenso quanto ao conteúdo dessa categoria jurídica, de modo que as insuperáveis oscilações conceituais da expressão não permitem a atribuição dum regime jurídico próprio, desaconselhando o seu uso no Direito.

\subsection{Das Entidades do Terceiro Setor}

De acordo com Marcela Roza Leonardo ZEN (2008, p. 76), a expressão terceiro setor surgiu nos Estados Unidos na década de 1970, difundindo-se pelos países europeus na seguinte, sempre a referir, tanto num quanto noutro, as entidades privadas sem fins lucrativos que realizam atividades voltadas à satisfação do bem comum.

Rita TOURINHO (2010, p. 321-322) leciona que, de origem sociológica, partindo da ideia de que o Estado é o primeiro setor e a iniciativa privada voltada à exploração de atividade econômica o segundo, a locução terceiro setor não está positivada no ordenamento jurídico brasileiro, pelo que o conceito, no Direito, a despeito de ser amplamente

inciso XIX do art. 37 da Constituição Federal - com a maior autonomia que lhe é conferida pelo Decreto-Lei $n^{\circ}$ 2.299/1986, nomeadamente a ausência de supervisão ministerial, esta que é modalidade do controle interno previsto no 70 da Constituição. A única incongruência instransponível, contudo, é a possibilidade de lei infraconstitucional afastar as prescrições constitucionais do art. 37 da Constituição Federal a tais entidades, que tanto lhes conferem prerrogativas quanto lhes impõem sujeições especiais.

${ }^{123}$ Embora afirme que as classificações, enquanto formas artificiais de organização do pensamento, não impedem discrepâncias do padrão, inclusive para admitir a ocorrência de objetos ímpares, fora das categorias jurídicas organizadas pelo conhecimento humano, Durval CARNEIRO NETO (2006, p. 277-282; 306-308) acaba, com o devido respeito, contradizendo-se ao pretender equiparar a Ordem dos Advogados do Brasil com os conselhos de fiscalização profissional em geral, como se a lógica empregada pelo Pretório Excelso na ADI $n^{\circ} 3.026-4 / D F$ à OAB pudesse se aplicar a todos indistintamente simplesmente pelo fato de serem entidades competentes para a fiscalização de profissões. 
reverenciado, é de desenvolvimento doutrinário, comumente equiparado às noções ordinárias de entes de cooperação, organizações não governamentais, entidades de caridade, dentre outras, todas relativas ao conjunto de iniciativas privadas sem fins lucrativos voltadas à produção de bens e serviços de interesse público.

Nesse trilhar, sem previsão em nosso texto constitucional ${ }^{124}$, a doutrina jurídica brasileira se esforça para oferecer conceitos abrangentes de terceiro setor, numa tentativa de nele incluir quaisquer entidades que, ao mesmo tempo, não se insiram na estrutura do Estado nem se enquadrem no âmbito das pessoas jurídicas não estatais voltadas ao lucro, sendo certo que inexiste em nosso país conteúdo unívoco para a expressão ${ }^{125}$.

Apresentando um conceito material de terceiro setor, Gustavo Justino de OLIVEIRA (2007b, p. 16-17) afirma se tratar do:

[...] conjunto de atividades voluntárias, desenvolvidas por organizações privadas não-governamentais e sem ânimo de lucro (associações ou fundações), realizadas em prol da sociedade, independentemente dos demais setores (Estado e mercado), embora com eles possa firmar parcerias e deles possa receber investimentos (públicos e privados) ${ }^{126}$.

Valendo-se da expressão terceiro setor para designar as entidades privadas sem fins lucrativos de fins públicos que celebram contratos de parceria com o Estado, Carlos Ari SUNDFELD e Rodrigo Pagani de SOUZA (2011, p.75-76) ensinam que, não integrando o aparelho do Estado, tais em organizações da sociedade civil não se sujeitam a ônus nem usufruem de privilégios atrelados às entidades estatais: em matéria de ônus, não têm, por exemplo, dever de licitar ou de contratar agentes por concurso público; em matéria de benefícios, não gozam prazos processuais e prescricionais próprios, não se beneficiam da imunidade tributária recíproca, não recebem recursos públicos por simples destinação orçamentária [independentemente de contraprestação], não exercem poder de polícia, nem

${ }^{124}$ Gustavo Alexandre MAGALHÃES (2012, p. 53) observa que a Constituição Brasileira de 1988 utiliza vários termos para se referir às entidades do terceiro setor, não a utilizando, contudo, em momento algum.

${ }^{125}$ De acordo com Vital MOREIRA (1997, p. 16), o terceiro setor traduz a ideia de um campo intermédio entre o Estado e o mercado, entre o público e o privado [leia-se, entre o estatal e o não estatal], que compartilha traços de cada um deles, reunindo a prestação de bens e serviços por parte de organizações não estatais e não lucrativas muito diversas, como as cooperativas, as mutualidades, as igrejas, as organizações beneficentes e as fundações de fins sociais.

${ }^{126}$ Em sentido semelhante, mas preferindo um enunciado subjetivo de terceiro setor: Boaventura Souza SANTOS (1998, p. 05), Celso Antônio Bandeira de MELLO (2009, p. 224), José Eduardo Sabo PAES (2000, p. 56), Paulo Eduardo Garrido MODESTO (2006, p.07; 2011, p. 08); Rita TOURINHO (2010, p. 321), Rodrigo Pironti Aguirre de CASTRO (2008, p. 167) e Silvio Luís da Silva ROCHA (2003, p. 15). A bem da verdade, há alguma diferença entre os conceitos apresentados por esses autores, havendo aqueles que fazem expressa menção à possibilidade de parcerias com o Estado e à voluntariedade na criação dessas entidades. 
seus agentes possuem vantagens funcionais que a Constituição e as leis dão aos servidores públicos. Ainda segundo os Autores, mesmo quando constituem com o Estado vínculos de parceria para a prestação de serviços de relevância pública, não se transformam em Estado, sujeitando-se, sim, a determinados ônus relacionados à circunstância de estarem atuando como contratadas do Poder Público, mas não como se lhes fosse aplicável o tratamento jurídico reservado às repartições públicas.

Aldino GRAEF e Valéria SALGADO (2012, p.15-16) ponderam que esse prevalente conceito de terceiro setor - enquanto um "conjunto de entidades que não integram a estrutura do estado (primeiro setor) e do mercado (segundo setor), constituídas como pessoas jurídicas de direito privado, sob o substrato de associações, fundações, instituições religiosas ou partidos políticos"127 - carece de clareza e objetividade, dado que formulado a partir de definições negativas, da ausência de atributos, como em sem fins lucrativos ou em que não integram a estrutura do Estado.

Para esses Autores (2012, p. 15-16), estariam reunidas organizações com naturezas e finalidades completamente distintas, sem qualquer relação entre si, tais como: igrejas e todas as variantes filosóficas; partidos políticos; sindicatos e outras associações de classe; cooperativas sem fins lucrativos; grêmios e diretórios estudantis; sociedades científicas; clubes sociais e desportivos; sociedades beneficentes; congregações e ordens religiosas, incluídas a CNBB e as pastorais; associações de bairros ou de moradores; torcidas organizadas de clubes de futebol; escolas de samba e outras formas de organização socioculturais; sociedades filosóficas; clubes de nudismo ou naturismo; movimentos sociais de defesa de direitos de grupos ou setores específicos da sociedade, como os direitos da mulher e os direitos de grupos sociais minoritários ou marginalizados; movimentos sociais em defesa do meio ambiente, em suas muitas vertentes; fundações de todas as áreas de atividades; e os diversos tipos de associações, como as de pais e mestres nas escolas.

Também Maria Sylvia Zanella DI PIETRO (2003, p. 407) observa que a noção corrente de terceiro setor acaba englobando três ordens de entidades: (i) aquelas que prestam atividades sociais por iniciativa própria, sem substituir a atuação dos entes estatais, como ocorre com as declaradas de utilidade pública, os serviços sociais autônomos e as organizações da sociedade civil de interesse público; (ii) aquelas que substituem total ou parcialmente a atuação de entidades estatais, como ocorre com as fundações de apoio; e (iii)

${ }^{127}$ Isto é, numa das formas de pessoa jurídica sem fins lucrativos previstas pelo art. 44 do Código Civil de 2002. 
outras que foram idealizadas pelo próprio governo para absorver atividades realizadas por entidades estatais, a exemplo das organizações sociais ${ }^{128}$.

A nosso sentir, as dificuldades de lidar, no campo do Direito, com essa consagrada noção de terceiro setor parecem decorrer da sua referida origem sociológica, mais afeta, talvez, às Ciências Econômicas e Políticas, não tendo o regime jurídico como o critério aglutinador das entidades componentes.

Além disso, o conceito assente de terceiro setor geralmente não leva em consideração a atividade desenvolvida pela organização, bastando se tratar, como visto, de pessoa jurídica não estatal sem fins lucrativos, não inserta no mercado ou na estrutura estatal. Com efeito, não há qualquer exigência de ter por objeto atividades sociais ${ }^{129}$, de modo que, sob o pálio da realização do interesse público, as suas entidades acabam atuando até mesmo na política (enquanto associações de promoção de interesses de grupos políticos ou mesmo sob a forma de partidos políticos) e na religião (por meio de organizações religiosas ou simples associações de propagação de determinado credo), em nada relacionadas, evidentemente, com o fornecimento de utilidades materiais essenciais ao bem-estar, à dignidade humana e à justiça social.

$\mathrm{Na}$ verdade, ainda que se diga que o terceiro setor está adstrito ao campo dos serviços sociais - o que, repita-se, não se percebe dos conceitos oferecidos pela doutrina pátria -, é preciso reconhecer que mesmo o setor social não possui uma delimitação tão clara em nosso ordenamento jurídico, bastando consultar o Título VIII da nossa Constituição Federal de 1988 para identificar a grande variedade das áreas componentes da chamada ordem social, a qual vem caracterizada finalisticamente, pelos objetivos do bem-estar e da justiça sociais (art. 193), e abrange a seguridade social, a educação, a cultura, o desporto, a ciência e tecnologia, a comunicação social, o meio ambiente, a família, a criança, o adolescente, o idoso e os índios ${ }^{130}$.

Ademais, verifica-se que essa noção corrente de terceiro setor acaba por incluir: (i) entidades livremente criadas pela iniciativa privada ${ }^{131}$, que surgem e passam a funcionar,

\footnotetext{
${ }^{128}$ É justamente por isso que José Eduardo Sabo PAES (2005, p. 5094) ressalva que “[...] o Terceiro Setor tem uma grande abrangência não só na sua forma de atuação, como com relação às entidades ou organizações sociais que o constituem, não havendo, ainda, no âmbito do ordenamento jurídico brasileiro, uma definição exata em lei do que seja esse setor, de que se compõe e em que áreas atua".

${ }^{129}$ A noção de atividades sociais será trabalhada no Capítulo 4 desta Primeira Parte.

${ }^{130}$ Falaremos com maior vagar sobre a noção de atividades sociais em item próprio.

${ }^{131}$ Mais uma vez, esclareça-se que a expressão "iniciativa privada" é aqui empregada como sinônimo de não estatal, como fora da estrutura da Administração Pública, não guardando relação com a natureza jurídica de direito privado dessas entidades, afinal de contas, encontramos pessoas jurídicas de direito privado também no
} 
nos termos da parte inicial do art. 45 do Código Civil de 2002, com a inscrição dos seus atos constitutivos no registro de pessoas jurídicas, simplesmente adotando a forma de associação ou fundação ${ }^{132}$, ou assumindo a natureza de instituição religiosa ${ }^{133}$; (ii) entidades que dependem de algum impulso oficial [do Estado] para serem criadas, exatamente como ocorre com os abordados serviços sociais autônomos, que são autorizados ou criados por lei; e (iii) organizações que, embora a decisão de instituição parta dos particulares, se sujeitam a inúmeras restrições impostas pela lei ou dependem de alguma chancela especial do Poder Público para serem criadas ou entrarem em perfeito funcionamento, tal qual sucede com os partidos políticos ${ }^{134}$, as cooperativas ${ }^{135}$ e algumas espécies de associações ${ }^{136}$. O conceito não cumpre, portanto, as exigências de voluntariedade na criação e de autoadministração e autogestão.

âmbito estatal, a exemplo, nos termos do art. $5^{\circ}$, II, III e IV, do Decreto-Lei 200, das empresas públicas, sociedades de economia mista e fundações públicas de direito privado.

${ }^{132}$ Obviamente, respeitando-se as exigências formais prescritas nos arts. 53-61 e 62-69 da Lei Civilista, respectivamente, para as associações e fundações, a exemplo, quanto a estas, da necessidade de instituição por escritura pública ou disposição de última vontade.

${ }^{133}$ Segundo a redação originária do Código Civil de 2002, as organizações religiosas possuíam natureza jurídica de associação, somente sendo reconhecidas como uma categoria jurídica própria através da edição da Lei Federal $\mathrm{n}^{\circ}$ 10.825/2003, que deu nova redação dos arts. 44 e 2.031 do compêndio civilista de 2002. Nos termos do $\S 1^{\circ}$ do art. 44 deste diploma normativo, "são livres a criação, organização, a estruturação interna e o funcionamento das organizações religiosas, sendo vedado ao poder público negar-lhes reconhecimento ou registro dos atos constitutivos e necessários ao seu funcionamento".

${ }^{134}$ Segundo o art. 17 da Constituição Federal de 1988, é livre a criação, fusão, incorporação e extinção de partidos políticos no Brasil, observados, contudo, determinados preceitos, a exemplo do caráter nacional e da necessidade de, após a aquisição de personalidade jurídica (através do registro no Cartório de Pessoas Jurídicas de Brasília), inscreverem os seus atos constitutivos no Tribunal Superior Eleitoral - TSE (respeitando-se as exigências de assinaturas mínimas e distribuição em pelo menos um terço dos Estados da Federação). Todo o procedimento de criação dos partidos políticos vem minuciosamente disciplinado na Lei Federal no 9.096/1995 e em diversas Resoluções editadas pelo TSE.

${ }^{135}$ As cooperativas estão reguladas genericamente nos arts. 1.093 e ss. do Código Civil de 2002 e na Lei Federal $\mathrm{n}^{\mathrm{o}}$ 5.764/1971, submetendo-se, ainda, à disciplina de legislações especiais, a exemplo das Leis Federais $\mathrm{n}^{\circ} \mathrm{s}$ 9.867/1999 (cooperativas sociais) e 12.690/2012 (cooperativas de trabalho) e da Lei Complementar Federal $\mathrm{n}^{\mathrm{o}}$ 130/2009 (cooperativas de crédito). Destinam-se, pois, ao exercício de uma atividade econômica (leia-se, que gera excedentes financeiros), de proveito comum, sem objetivo de lucro (vale dizer, que não distribui dividendos entre os cooperados, reaplicando os excedentes na atividade desenvolvida pela cooperativa e na disponibilização de benefícios especiais aos seus membros), sendo orientadas pelos princípios da dupla qualidade (os filiados são, ao mesmo tempo, cooperados e clientes, sendo um dos beneficiários centrais dos serviços prestados) e da retribuição pessoal diferenciada (ainda que em potencial, cada cooperado receberá retribuição pessoal maior do que àquela que seria alcançada em atuação isolada). Embora as cooperativas em si não possuam finalidade lucrativa, esta é potencialmente existente, já que elas objetivam o exercício de atividades econômicas pelos seus cooperados, reaplicando os seus excedentes nos serviços oferecidos aos seus membros e distribuindo-os a título de retribuição pessoal diferenciada.

136 Verbi gratia, os sindicatos, entendidos como associações representativas de categorias profissionais (laborais, de trabalhadores) ou econômicas (patronais, empresariais) que, conquanto a sua criação independa de qualquer autorização estatal, ganhando personalidade jurídica com a inscrição dos seus atos constitutivos no Cartório de Registro de Pessoas Jurídicas, têm o seu funcionamento enquanto associação de representação de trabalhadores ou empregadores dependente de registro no Ministério do Trabalho e Emprego - MTE, devendo observar as restrições contidas no art. $8^{\circ}$ da Constituição Federal de 1988 e em outras normas legais e regulamentares. 
Ainda, acaba-se por não fazer a referida distinção entre entidades de favorecimento mútuo ou de fins mútuos e entidades de fins comunitários, públicos ou de solidariedade social, não permitindo identificar uma categoria jurídica idônea à colaboração com o Estado na prestação de serviços sociais, viabilizando a concessão de benesses oficiais a instituições em nada dirigidas ao bem-estar de toda a sociedade, contribuindo para o desvio de poder na Administração Pública e para o descrédito das parcerias sociais entre os setores público e privado..

Fica claro, portanto, em que pese serem todas pessoas jurídicas de direito privado, estando orientadas, a princípio, pelos ditames da autonomia privada e da igualdade ${ }^{137}$, as entidades integrantes dessa noção corrente de terceiro setor submetem-se a regimes jurídicos diferenciados, com distinções importantes quanto à sua criação, organização, funcionamento e encerramento.

Bastante preocupada com a preservação do caráter privado das entidades do terceiro setor, notadamente dos princípios da liberdade de associação e de auto-organização que lhe subjazem, Paula Raccanello STORTO (2013, p. 364) observa a possibilidade delas atuarem independentemente de qualquer auxílio do Estado, “como entidades típicas da sociedade civil organizada que atua de forma crítica e independente, fazendo pressão pública e exercendo o controle social sobre as atividades governamentais". Ela anota o frequente equívoco em compreender o terceiro setor como um braço do Estado, destacando a excessiva associação dessa expressão ao processo de Reforma do Estado dos anos 90, como se ele atuasse necessariamente em cooperação com o Poder Público, mediante vínculos jurídicos oficiais de transferência, delegação ou terceirização de atividades típicas da Administração Pública. Ainda segundo a Autora, outro erro muito comum é a atribuição duma espécie de competência residual ao terceiro setor, segundo a qual lhe caberia atuar apenas nas questões sociais e nas políticas públicas não encampadas e executadas pelo primeiro e segundo setor de forma satisfatória.

Para nós, os equívocos apontados pela Autora traduzem uma visão reducionista da importância das entidades do terceiro setor na sociedade, a mitigar o seu decisivo papel na

\footnotetext{
${ }^{137}$ Segundo os quais há certa liberdade na decisão de criação e extinção da pessoa jurídica, bem como na definição dos seus objetivos, organização e modo de funcionamento, estabelecendo relações civis e comerciais com outras entidades de forma paritária, sem privilégios ou sujeições especiais. Obviamente, essas pessoas jurídicas sem fins lucrativos sempre estarão submetidas às normas cogentes previstas em nosso sistema jurídico, mormente em razão da natureza social das suas atividades, devendo respeitar, por exemplo, os direitos fundamentais - eficácia horizontal - e a função social dos contratos, da posse e da propriedade.
} 
realização dos direitos fundamentais, lançando por terra o princípio da participação social e da democracia substantiva, na contramão daquilo que Diogo de Figueiredo MOREIRA NETO (2006, p. 389) intitula fragmentação e despublicização do interesse público, este que não mais se restringe às fronteiras duma Administração Pública Subjetiva ou Estatal, monista e monorganizada, pretensa titular oficial dos interesses da sociedade.

Anote-se que o já referido Anteprojeto de Estatuto Jurídico do Terceiro Setor traz em seu art. $2^{\circ}$ um conceito legal de terceiro setor, enquanto um conjunto de pessoas jurídicas de direito privado, de caráter voluntário e sem fins lucrativos que: (i) desenvolvem atividades de promoção e defesa de direitos, principalmente os coletivos e difusos; (ii) realizam atividades de interesse público, assistência social ou utilidade pública, nos termos definidos em lei; ou (iii) prestam serviços sociais diretamente à população, em caráter complementar ou suplementar aos serviços prestados pelo Estado ${ }^{138}$.

Por sua vez, o art. $3^{\circ}$ desse Anteprojeto contém uma lista exemplificativa das entidades que podem ser enquadradas na noção de terceiro setor, tal como as associações de moradores, as Santas Casas de Misericórdia e hospitais, as instituições de ensino ou de educação profissional, as cooperativas sociais tratadas pela Lei Federal n ${ }^{\circ}$ 9.867/99 e as associações e fundações de fins culturais, artísticos, esportivos, recreativos e de lazer.

Em seu art. $4^{\circ}$, esse Anteprojeto enumera a pessoas jurídicas excluídas do conceito de terceiro setor, a exemplo das: (i) autorizadas ou criadas por lei (sem voluntariedade); (ii) que o Poder Público participe compulsoriamente em seus órgãos de direção, deliberação e administração (sem independência); (iii) mantidas por contribuições fiscais e parafiscais do Poder Público (sem independência); (iv) destinadas a proporcionar bens ou serviços a um segmento restrito de associados ou sócios, em regime de mutualidade (entidades de favorecimento mútuo ou de fins mútuos); e (v) com natureza de sindicatos, associações de classe ou de representação de categoria profissional (entidade de favorecimento mútuo ou de fins mútuos).

Percebe-se - inclusive da leitura da nota explicativa desse art. $4^{\mathbf{o}}$ - que o Anteprojeto se preocupa em reforçar o caráter voluntário e independente dessas entidades,

\footnotetext{
${ }^{138}$ De acordo com nota explicativa do art. $2^{\circ}$ desse Anteprojeto, o conceito normativo ali proposto está alinhado com os elementos conceituais propostos pela Divisão de Estatísticas da Organização das Nações Unidas ONU e pela Universidade John Hopkins, expressados no Manual sobre Instituições Sem Fins Lucrativos no Sistema de Contas Nacionais (2002) e na Classificação dos Objetivos das Instituições sem Fins Lucrativos ao Serviço das Famílias - COPNI. Além disso, esclarece que o Instituto Brasileiro de Geografia e Estatística IBGE vem adotando essa metodologia na divulgação de estatísticas sobre o Terceiro Setor no Brasil.
} 
afastando de vez a inclusão de pessoas jurídicas cuja criação dependa de algum esforço oficial ou cuja manutenção e financiamento estejam exclusivamente a cargo do Estado, o que configuraria os tais simulacro de descentralização ou fuga para o direito privado. Procurando também afastar entidades que não se prestam à realização dos interesses coletivos e assegurar a aptidão das entidades do terceiro setor a celebrar vínculos de colaboração com o Poder Público ${ }^{139}$, o Anteprojeto deixa claro a exclusão daquelas entidades cuja atuação seja endógena, dirigida ao referido espaço corporativo, atendendo apenas aos seus representantes e filiados, não se voltando à comunidade ${ }^{140}$.

Embora consideremos louvável a intenção desse Anteprojeto de reforçar o caráter voluntário e autônomo das entidades do terceiro setor, entendemos indevida a exclusão peremptória das entidades em que o Estado participe compulsoriamente de seus órgãos de direção, deliberação e administração. Sucede que tais pessoas jurídicas não são necessariamente subordinadas à Administração Pública, tudo dependendo daquilo que for previsto nas normas de regência da entidade, especialmente daquelas contidas em seu estatuto. Mantida a autonomia mínima da entidade em relação ao Poder Público, vislumbramos uma proximidade entre o seu regime normativo e o das demais entidades do terceiro setor tal qual caracterizado no Anteprojeto, devendo, então, ser incluídas nesta categoria jurídica. Tomando as organizações sociais de âmbito federal, por exemplo, temos que, de acordo com o art. 3, I, “a”, da Lei Federal no 9.637/98, apenas 20\% a 40\% do seu conselho de administração será integrado por representantes do Poder Público, o que, salvo alguma espécie de voto diferenciado previsto no estatuto, não representa o seu controle pelo Estado, estando preservada, de certo modo, a sua liberdade de ação.

Também não vemos sentido em excluir da noção de terceiro setor toda e qualquer organização da sociedade civil sem fins lucrativos que receba contribuições fiscais ou parafiscais para a sua manutenção. Salvante a hipótese de serem instituídas diretamente pelo Estado ou totalmente custeadas com recursos públicos - caso em que nada mais seriam do que uma ferramenta de ação do Estado, ou, nos dizeres de Fernando Facury SCAFF (2001,

\footnotetext{
${ }^{139}$ O Título VI desse Anteprojeto disciplina as parcerias do Terceiro Setor com o Estado, as empresas e a sociedade civil, tratando no seu Capítulo II da colaboração com o Poder Público. O Anteprojeto optou por não trazer uma disciplina pormenorizada das parcerias do Terceiro Setor com o Estado, limitando-se a afirmar que somente poderão ser beneficiárias de recursos financeiros públicos - a título de auxílios financeiros, contribuições ou subvenções, financiamentos, favores fiscais ou outras transferências voluntárias - as entidades do Terceiro Setor regularmente inscritas no Cadastro Nacional das Entidades do Terceiro Setor, do Ministério da Justiça, bem como a prever a edição de lei especificamente sobre essas parcerias e ao processo de seleção pública das entidades do Terceiro Setor parcerias do Estado.

${ }^{140}$ Como bem destaca a nota explicativa do art. $7^{\circ}$ desse Anteprojeto, "a diretriz fundamental do Terceiro Setor é a promoção do bem-estar e do desenvolvimento integrado dos indivíduos e da sociedade".
} 
p. 287), uma contrafação de descentralização -, pensamos estar preservada a sua autonomia, pelo que merecem a sua inclusão no conceito e a sua submissão a um regime jurídico comum mínimo.

Perfilhamos, pois, o entendimento de que, além da finalidade não lucrativa e da vocação para a coletividade, o terceiro setor deve ser marcado justamente pela autonomia de organização e funcionamento, em defesa da natureza jurídica não estatal de direito privado das suas entidades. Nesse sentido, Paula Raccanello STORTO (2013, p. 368-9) destaca que o Primeiro Relatório da Relatoria Especial do Conselho de Direitos Humanos da ONU, de 20/06/2012, estabelece que o terceiro setor é uma expressão do direito de liberdade de associação, exercendo um papel decisivo no surgimento e existência de eficazes sistemas democráticos, dado que são favoráveis ao diálogo, tolerância, pluralismo e abertura de espírito, sendo a sua maior dificuldade justamente o controle estatal frequentemente imposto por regulamentações duras e punitivas.

A despeito da equivocidade da expressão terceiro setor em nosso país, consideramos que sua consagração na doutrina e prática jurídicas recomenda sua utilização no presente trabalho, apenas ressalvando-se que o sentido aqui empregado é o de organizações da sociedade civil sem fins lucrativos voluntárias, autoadministradas e de fins comunitários, públicos ou de solidariedade social.

\subsection{Das Alternativas Terminológicas}

Diante da ausência de uniformidade conceitual em nosso ordenamento jurídico e das equivocidades das expressões que foram surgindo entre os doutrinadores brasileiros para designar aquelas pessoas jurídicas não estatais de direito privado sem fins lucrativos que atuam no setor social, a doutrina especializada vem trabalhando as seguintes alternativas terminológicas: (i) fundações privadas e associações sem fins lucrativos; (ii) organizações da sociedade civil; (iii) entidades de colaboração.

A expressão fundações privadas e associações sem fins lucrativos (ou simplesmente FASFIL) ${ }^{141}$ foi a opção da já referida pesquisa realizada em parceria pelo

\footnotetext{
${ }^{141}$ Não se trata propriamente duma locução concisa conglobante das organizações não estatais de direito privado voluntárias, autoadministradas e de fins comunitários, públicos ou de solidariedade social, mas de expressão extensa que se vale dos elementos que caracterizam juridicamente tais entidades. A intenção parece
} 
IBGE, IPEA, ABONG e GIFE, designando toda e qualquer organização privada sem fins lucrativos que seja, concomitantemente, institucionalizada, autoadministrada e voluntária ${ }^{142}$. Incluindo as associações, fundações e organizações religiosas, a noção de FASFIL não exige, todavia, vocação social da entidade, não importando se tratar de organização efetivamente dirigida ao atendimento das necessidades da comunidade (entidade de fins comunitários, públicos ou de solidariedade social). Por esse motivo, a expressão acaba por não possuir serventia ao presente trabalho ${ }^{143}$.

Por sua vez, temos a noção de organização da sociedade civil, originariamente defendida em nosso país pela Plataforma por um Novo Marco Regulatório para as Organizações da Sociedade Civil ${ }^{144}$ e recentemente inserida em nosso ordenamento jurídico através do art. $2^{\circ}$, I, da Lei Federal n ${ }^{\circ} 13.019$, de 31/07/2014 ${ }^{145}$, de acordo com o qual cuidase de:

[...] pessoa jurídica de direito privado sem fins lucrativos que não distribui entre os seus sócios ou associados, conselheiros, diretores, empregadores ou doadores, eventuais resultados, sobras, excedentes operacionais, brutos ou líquidos, dividendos, bonificações, participações ou parcelas do seu patrimônio, auferidos mediante o exercício de suas atividades, e que os aplica integralmente na consecução do respectivo objeto social, de forme imediata ou por meio da constituição de fundo patrimonial ou fundo de reserva.

ter sido a de evitar aglutinações terminológicas que acabam por contribuir para a insegurança no seu tratamento jurídico.

${ }^{142}$ Considerando esses critérios, a pesquisa exclui do universo das FASFILs, por exemplo, os partidos políticos (não são voluntários), as entidades sindicais (não são voluntárias) e os serviços sociais autônomos (não são voluntários).

${ }^{143}$ Embora a parte final do inciso I do art. 19 da Constituição Federal de 1988 admita a colaboração de interesse público entre o Estado a as organizações religiosas, é importante observar que essas entidades privadas não têm por objeto principal o atendimento das necessidades coletivas, de oferecimento de serviços sociais à comunidade. Assim sendo, eventual apoio prestado pelo Estado não adéqua à noção de contrato de colaboração defendida nesta dissertação, estando sujeita a um regime jurídico próprio.

${ }^{144}$ Iniciativa de âmbito nacional lançada em 2010 por redes, movimentos e entidades de caráter social em prol dum novo marco regulatório que consolide uma relação harmônica e construtiva dessas instituições com o Estado e com a própria sociedade, a Plataforma participou de Grupo de Trabalho constituído na Secretaria da Presidência da República para estudar o tema. Este Grupo de Trabalho foi responsável pela elaboração do Anteprojeto de Lei que inspirou o Substitutivo apresentado no Senado Federal, este que, por sua vez, deu origem ao Projeto de Lei Federal $n^{\circ}$ 7.168/14, base da Lei Federal $n^{\circ}$ 13.019/2014 recentemente aprovada. Hoje, a Plataforma trabalha ativamente pela regulamentação de diversos dispositivos dessa normativa federal, especialmente preocupada com as ingerências na liberdade de associação e de auto-organização, buscando a simplificação e clareamento das exigências impostas para a celebração de parcerias nos serviços sociais, mormente quando envolvidos baixo montante de recursos públicos e entidades de pequeno porte. Acerca da Plataforma, visitar a sua página da internet: <www.plataformaosc.org.br/plataforma/>.

${ }^{145}$ De acordo com sua ementa, "Estabelece o regime jurídico das parcerias voluntárias, envolvendo ou não transferências de recursos financeiros, entre a administração pública e as organizações da sociedade civil, em regime de mútua cooperação, para a consecução de finalidades de interesse público; define diretrizes para a política de fomento e de colaboração com organizações da sociedade civil; institui o termo de colaboração e o termo de fomento; e altera as Leis n's 8.429, de 2 de junho de 1992, e 9.790, de 23 de março de 1999”. 
Num primeiro momento, esse conceito legal de organização da sociedade civil parece admitir o enquadramento de entidades de favorecimento mútuo, como se bastasse se tratar de pessoa jurídica de direito privado sem fins lucrativos. No entanto, uma interpretação sistemática dos dispositivos da Lei deixa claro que a parceria nela disciplinada é aquela dirigida ao incentivo de atividades de interesse público, afastando a possibilidade da celebração dos instrumentos de cooperação nela tratados (termo de colaboração e termo de fomento) com o já mencionado espaço corporativo, de atuação endógena ${ }^{146}$.

Além da impropriedade decorrente da falta de limitação direta e objetiva às entidades de fins comunitários, públicos ou de solidariedade social - a despeito, como visto, da inexistência de dúvidas quanto à abrangência da noção legal -, a redação do inciso I do art. $2^{\circ}$ é truncada, sem qualquer vírgula que evidencie se tratar de aposto que apenas esclarece o sentido que se pretende conferir ao qualificativo sem fins lucrativos ${ }^{147}$.

É importante observar, outrossim, que a Lei Federal no 13.019/2014 disciplina as parcerias celebradas através dos chamados termos de colaboração e termos de fomento, não se aplicando automaticamente às demais relações de cooperação de toda e qualquer entidade que se insira na noção legal de organização da sociedade civil. Em outras palavras, não basta se inserir no conceito de organização da sociedade civil para que a Lei de Parcerias Sociais regule os instrumentos de cooperação já celebrados ou que venham a ser celebrados por entidades privadas sem fins lucrativos com a Administração Pública. Assim sendo, por exemplo, uma mesma entidade poderá ser considerada como de utilidade pública (Lei Federal n 91/1935), organização social (Lei Federal no 9.637/1998), organização da sociedade civil de interesse público (Lei Federal nº 9.790/1999) ou entidade beneficente de assistência social (Lei Federal $n^{\circ}$ 12.101/2009), sujeitando-se as eventuais parcerias celebradas com o Poder Público às respectivas disciplinas legais específicas, e, ao mesmo tempo, ser enquadrada como organização da sociedade sem fins lucrativos para os fins da

\footnotetext{
146 A própria ementa da Lei consigna expressamente que ela estabelece o regime jurídico das parcerias voluntárias para a consecução de finalidades de interesse público. Da mesma forma, os conceitos de termo de colaboração e termo de fomento oferecidos no art. $2^{\circ}$ da Lei restringem indubitavelmente a sua abrangência às finalidades de interesse público.

${ }^{147}$ Não nos parece correta a crítica feita pela Plataforma no sentido de que o legislador devia ter admitido parcerias com "entidades que distribuam 'sobras' aos seus membros", a se admitir o fomento às cooperativas (vide Ponto 4 da aludida Primeira Contribuição da Plataforma das OSCs para o Processo de Regulamentação da Lei no 13.019/2014). As nossas razões já foram explicitadas no presente trabalho.
} 
Lei Federal $n^{\circ}$ 13.019/2014, firmando termo de cooperação ou termo de fomento e atraindo a sua disciplina normativa ${ }^{148}$.

A despeito das inadequações referidas, a definição legal conglobante das entidades idôneas à celebração de parcerias com o Estado nos serviços de interesse público é extremamente valiosa para a uniformização do regime jurídico dessa cooperação, viabilizando um ambiente de segurança jurídica tão indispensável à potencialização da participação social institucionalizada na realização dos fins públicos. Trata-se de verdadeiro avanço do marco regulatório das parcerias estatais não estatais nos serviços sociais.

Por fim, destacamos a opção do mencionado Anteprojeto de Reforma da Administração Pública Federal e Entidades Paraestatais e de Colaboração, que uniformiza o gênero das pessoas jurídicas sem fins lucrativos que presentam serviços de relevância pública [sociais] na locução entidade de colaboração ${ }^{149}$.

Segundo Maria Sylvia Zanella DI PIETRO (2010a, p. 2476), esse Anteprojeto objetivou congregar entidades de traços comuns independentemente do seu nomem juris específico, submetendo todas às suas normas, uniformizando minimamente os respectivos regimes jurídicos através da disciplina daquilo que se intitulou contrato de colaboração. A locução abrangeria, além das entidades de apoio ${ }^{150}$, as organizações sociais, as entidades da sociedade civil de interesse público, as entidades declaradas de utilidade pública e qualquer outra modalidade congênere prestante de serviços de relevância pública ${ }^{151}$. Reportando-se à redação do art. 73 do Anteprojeto, a Autora (2010, p. 248) conceitua as entidades de colaboração como:

[...] pessoas jurídicas de direito privado não estatais (porque não integram a Administração Pública direta ou indireta), sem fins lucrativos, constituídas voluntariamente por particulares (e não pelo poder público), que desenvolvem atividades de relevância pública, essenciais à coletividade, objeto de incentivo e fiscalização regular do Poder Público.

\footnotetext{
${ }^{148}$ Ressalve-se, contudo, as interações existentes entre esses regimes legais, especialmente as mencionadas concorrências e exclusões recíprocas estabelecidas pela Lei Federal nº 13.019/2014.

${ }^{149}$ Acerca deste Anteprojeto, ver a obra Nova Organização Administrativa Brasileira, que foi coordenada por Paulo Eduardo Garrido MODESTO e contém artigos dos juristas membros da Comissão elaboradora.

${ }^{150}$ Maria Sylvia Zanella DI PIETRO (2012, p. 559) leciona que as entidades de apoio são "pessoas jurídicas de direito privado, sem fins lucrativos, instituídas por servidores públicos, porém em nome próprio, sob a forma de fundação, associação ou cooperativa, para a prestação, em caráter privado, de serviços sociais não exclusivos do Estado, mantendo vínculo jurídico com entidades da administração direta ou indireta, em regra por meio de convênio".

151 Conforme já mencionado, o Anteprojeto não inclui os serviços sociais autônomos e as corporações profissionais no gênero dos entes de colaboração, preferindo chamá-los de entidades paraestatais.
} 
Percebe-se que o Anteprojeto traz a referida distinção entre entidades de favorecimento mútuo ou de fins mútuos e entidades de fins comunitários, públicos ou de solidariedade social, apenas admitindo a celebração de contratos de colaboração com aquelas pessoas jurídicas não estatais que se destinem à realização de atividades de interesse público, voltadas ao atendimento das necessidades da comunidade, evitando desvios de finalidade em matéria de fomento estatal.

Acerca das entidades de colaboração, registre-se as palavras de Paulo Eduardo Garrido MODESTO (2011, p. 12), in verbis:

As entidades de colaboração não são delegadas do Estado e não gozam de prerrogativas de direito público, processuais e materiais. Não editam atos administrativos, nem estão sujeitas ao processo administrativo para decidir. São entidades privadas, não estatais, que colaboram com o Estado, mas não se equiparam a ele ou a qualquer órgão do Poder Público. Como é sabido, poderes, prerrogativas públicas e sujeições não se presumem, sem norma de atribuição, especialmente para entidades privadas não estatais.

Além da segurança decorrente do seu assento em lei - anteprojeto de lei, na verdade -, a expressão entidades de colaboração é bastante precisa, pelo que se mostra adequada aos objetivos da presente dissertação. Na verdade, consideramos que, independentemente da opção terminológica adotada, o importante é ficar claro se tratar de pessoas jurídicas não estatais de direito privado que, além de reunir as mencionadas características das FASFIL (institucionalizada, autoadministrada e voluntária), sejam de fins comunitários, públicos ou de solidariedade social, prestando serviços sociais em benefício de toda a coletividade. Dessa forma, utilizaremos com tranquilidade tanto a expressão terceiro setor quanto entidades de colaboração nesta dissertação, tratando-as como sinônimas, designativas de toda e qualquer organização da sociedade civil sem fins lucrativos voltada ao atendimento desinteressado da comunidade. 


\section{DA NATUREZA JURÍDICA DO OBJETO}

Os contratos de colaboração têm por objeto os chamados serviços sociais, atividades de relevante interesse geral que, não submetidas à reserva de exclusividade estatal, estão constitucionalmente acometidas tanto ao Estado quanto à iniciativa privada.

Cuida-se do setor social, o qual, de acordo com José dos Santos CARVALHO FILHO (2013, p. 329), corresponde aos reclamos sociais básicos e representa ou uma atividade propiciadora de comodidade relevante, ou serviços assistenciais e protetivos, a exemplo dos serviços de assistência à criança e ao adolescente, médica e hospitalar, educacional e a comunidades carentes ${ }^{152}$.

De forma mais específica, Maria Sylvia Zanella DI PIETRO (2012, p. 116) explica que os serviços sociais atendem a necessidades coletivas e visam a realizar os direitos sociais do homem, sendo considerados fundamentais pelo art. $6^{\circ}$ e disciplinados pormenorizadamente no Título da Ordem Social (VIII), da Constituição Federal de 1988, a exemplo dos serviços de educação, saúde, alimentação, trabalho, moradia, lazer, segurança, previdência social, proteção à maternidade e à infância, assistência aos desamparados, dentro outros.

Em outros termos, eles servem à promoção e proteção dos chamados direitos sociais, ao quais se baseiam nos ideários da igualdade material e da solidariedade e objetivam garantir à comunidade melhores condições de vida, encontrando-se plasmados no art. $6^{\circ}$ e no Título VIII (Da Ordem Social), da Constituição Federal de 1988. Não se restringem, todavia, aos direitos sociais expressos na Constituição Federal de 1988,

\footnotetext{
${ }^{152}$ Em mesmo sentido, Marçal JUSTEN FILHO (2005, p. 499). Diversamente, valendo-se da classificação de Caio Tácito entre atividades jurídicas do Estado (equivalente a serviços públicos) e atividades sociais, Diogo de Figueiredo MOREIRA NETO (2014, p. 469-470) afirma que as segundas se diferenciariam das primeiras justamente por não serem essenciais da sociedade, tratando-se de meros interesses coletivos de fruição divisível, atendidos pelos serviços de utilidade pública, postos à disposição dos particulares. Apesar do espanto inicial que pode provocar, a concepção desse segundo Autor não está totalmente equivocada. É que ele propõe um sentido mais amplo de serviço público, abrangente não apenas das atividades que o Estado interdita à iniciativa privada, incluindo todos os serviços assegurados ou assumidos pelo Estado que se voltam à realização do interesse público [o autor limita-o aos serviços de fruição individual, ponto controverso que não interessa ao presente trabalho], sejam aquelas atividades dos arts. 21, 25 e 30 da Constituição, sejam as atividades econômicas prestadas nos termos do art. 173 do texto constitucional, sejam, ainda, e para nosso interesse, os componentes da Ordem Social.
} 
abrangendo quaisquer atividades de promoção e proteção da ordem social como um todo, voltadas de forma imediata à concretização do bem-estar e justiça sociais ${ }^{153}$.

É fundamental perceber que, fundado na livre iniciativa, o nosso sistema constitucional admite expressamente que os serviços sociais sejam prestados de forma econômica (lucrativa) ${ }^{154}$, caso em que, embora importem a geração de comodidades relevantes ao corpo social e representem atividades de interesse público, eles não estão diretamente voltados aos objetivos do bem-estar e justiça sociais previstos no art. 193 da Constituição Federal de 1998, não sendo orientados pelos princípios da igualdade material e da solidariedade social. Na realidade, possuem o objetivo direto de gerar ganhos patrimoniais e financeiros aos seus prestadores, sendo, a princípio ${ }^{155}$, nos termos do art. 170 da Lei Maior Brasileira, regidos pelos princípios gerais da atividade econômica, norteados pelos fundamentos da livre iniciativa e da livre concorrência ${ }^{156}$.

${ }^{153}$ Leandro Marins de SOUZA (2010, p. 74) observa que, embora a remissão contida na parte final do caput do art. $6^{\circ}$ ("na forma desta Constituição") faça parecer que o Título VIII da Constituição Federal ("Da Ordem Social") apenas traria a disciplina dos direitos sociais contidos naquele artigo, a verdade é que este Título vai além da mera regulamentação dos direitos sociais insculpidos no art. $6^{\circ}$, ampliando este rol com a inclusão da cultura, desporto, ciência e tecnologia, comunicação social, meio ambiente e índios enquanto espécies de direitos sociais. Insta compreender, ademais, que, diante da norma de abertura contida no $\S 2^{\circ}$ do art. $5^{\circ}$ da Lei Maior de 1988, há direitos sociais outros decorrentes do regime e dos princípios adotados na Constituição, bem como previstos em tratados internacionais de que a República Federativa do Brasil faz parte (por exemplo, o Pacto Internacional de Direitos Econômicos, Sociais e Culturais, adotado pela Resolução n.2.200-A (XXI) da Assembleia Geral das Nações Unidas, em 16 de dezembro de 1966, e ratificada pelo Brasil em 24 de janeiro de 1992). Nada impede, contudo, que a lei que disciplina especificamente determinada espécie de contrato de colaboração venha a limitar o âmbito material de sua aplicação, a exemplo do que ocorre com os contratos de gestão firmados pelo Estado de São Paulo, que estão circunscritos à área da saúde pela Lei Complementar Estadual n ${ }^{\circ}$ 846, de 04 de junho de 1998.

${ }^{154}$ Por exemplo, é o que se verifica com a saúde (art. 199), a previdência social (art. 202) e a educação (art. 209).

${ }^{155}$ Diz-se a princípio porque os serviços sociais prestados sob uma ótica econômica jamais estarão livres da incidência de normas jurídicas publicísticas, que limitam a autonomia da vontade e condicionam a liberdade dos particulares na organização e execução das atividades. É que são os próprios princípios da ordem econômica que restringem a liberdade dos agentes, a exemplo da função social da propriedade, da defesa do consumidor e do meio ambiente, da redução das desigualdades regionais e sociais e da busca do pleno emprego, todos inseridos no Título VII da Constituição Federal - "Da Ordem Econômica e Financeira". Ademais, consoante autoriza o art. 174 do texto constitucional, a sensibilidade do setor social sempre reclamará do Poder Público uma atividade normativa e reguladora mais intensa da atividade econômica, a exemplo do que ocorre com a saúde e educação no Brasil. Exemplificativamente, Paulo Eduardo Garrido MODESTO (2005, p. 23) anota que, conciliando os fundamentos da livre iniciativa e livre concorrência com os da defesa do consumidor e a redução das desigualdades sociais, o próprio STF já reconhece, no julgamento da $\mathrm{ADI} \mathrm{n}^{\circ}$ 319-QO/DF, a competência do Poder Público na regulação da política de preços nas atividades de ensino, confirmando a constitucionalidade da Lei Federal no 8.039/1990.

${ }^{156} \mathrm{Na}$ verdade, no limite, qualquer atividade tem aptidão para contribuir para o bem-estar e justiça sociais. De fato, mesmo atividades econômicas em sentido estrito - de produção de bens e serviços comerciais e industriais para o mercado - possuem o condão de gerar melhores condições de vida para a sociedade na medida em que produzam as já mencionadas externalidades positivas, verdadeiros benefícios indiretos - de caráter econômico, social, cultural ou ambiental - auferidos pela coletividade afetada/implicada/relacionada ao empreendimento lucrativo estimulado. Essas atividades, entretanto, não são serviços sociais em sentido próprio, visto que lhes falta a correspondência direta com a oferta de melhores condições de vida à sociedade, não estando orientadas pelos princípios da igualdade material e da solidariedade, mas por interesses econômicos privados. 
Nesse contexto, embora não neguemos o marcado interesse público do fornecimento lucrativo de comodidades/utilidades sociais, preferimos entender como serviços sociais apenas aqueles pautados pela igualdade material e solidariedade social, diretamente voltados à concretização do bem-estar e justiça sociais. Inclusive, conforme se explorará adiante, a circunscrição dos serviços sociais à realização imediata dos interesses sociais, isto é, de toda a sociedade, é indispensável à legitimidade dos contratos de colaboração, que não devem servir ao atendimento dos interesses privados de determinados grupos $^{157}$.

Destaque-se que, se a iniciativa privada está legitimada para organizar e prestar os serviços sociais em razão da consagração dos princípios constitucionais da cidadania (art. $1^{\mathrm{o}}, \mathrm{II}$ ), da democracia participativa (art. $1^{\mathrm{o}}$, par. único), da livre iniciativa (art. $1^{\mathrm{o}}, \mathrm{IV}$ ) e da autorização expressa da atuação não estatal contida em diversos dispositivos da Constituição Federal ${ }^{158}$, a possibilidade de sua execução pelo aparato estatal decorre da própria razão de ser do ente oficial, qual seja a de instrumentalizar a vontade social na persecução dos fins públicos, servindo ao atendimento das necessidades coletivas.

$\mathrm{Na}$ verdade, a já referida perspectiva instrumental do Estado impõe-lhe um verdadeiro dever de ação nas atividades de interesse público, sempre a garantir a concretização das utilidades coletivas e proteger os direitos fundamentais, seja na função preferencial de fomentador, regulador e fiscal da sua boa condução pelos particulares, seja enquanto um prestador direto residual.

Avançando, é preciso notar que o conceito de serviços sociais não informa de imediato o regime jurídico ao qual estão submetidos nem o seu titular, não indicando os princípios e regras que os disciplinam nem o responsável pela sua prestação. A noção, portanto, limita-se ao aspecto material das atividades, sem qualquer referência expressa aos

\footnotetext{
157 A propósito, o art. 213 da Constituição Federal Brasileira implicitamente fixa como requisito para o recebimento de recursos públicos por entidades privadas justamente a finalidade não lucrativa do empreendimento, donde resulta a impossibilidade do Poder Público firmar contrato de colaboração para fomentar atividades sociais prestadas em regime de mercado. Não é por outro motivo que todos os instrumentos normativos que disciplinam o trespasse de dinheiro público para entidades privadas de interesse social exigem o caráter não lucrativo do parceiro não estatal, limitando a possibilidade de parceria às associações e fundações privadas (verbi gratia, o art. $1^{\circ}$ da Lei Federal $n^{\circ}$ 9637/98, o art. $1^{\circ}$ da Lei Federal $n^{\circ} 9790 / 99$, o art. $1^{\circ}$ do Decreto-Federal $n^{\circ} 6.170 / 2007$ e o art. $2^{\circ}$, I, da novel Lei Federal n $\left.{ }^{\circ} 13.019 / 2014\right)$. Sem embargo, consoante já mencionado nesta dissertação, nada impede que o Estado implemente alguma espécie de fomento - diverso da transferência de recursos públicos - a atividades sociais com fins lucrativos - ou mesmo econômicas em sentido estrito -, almejando alcançar as já referidas externalidades positivas, através, por exemplo, da concessão de empréstimos graciosos, benesses fiscais, cessão de uso de terrenos.

158 Arts. 197; 199; 202; 204, I; 209; 216, § 1º; 218, § 4º e 225.
} 
elementos formal e subjetivo desses serviços, ficando a cargo da doutrina e jurisprudência, então, o seu encarte em categorias jurídicas próprias.

Na busca dessa adequação jurídica dos serviços sociais, a doutrina logo percebeu a impossibilidade de correspondê-los à noção tradicional de serviço público ${ }^{159}$, o qual, de acordo com Celso Antônio Bandeira de MELLO (2009, p. 665), corresponde a:

\begin{abstract}
[...] toda atividade de oferecimento de utilidade ou comodidade material destinada à satisfação da coletividade em geral, mas fruível singularmente pelos administrados, que o Estado assume como pertinente a seus deveres e presta por si mesmo ou por quem lhe faça as vezes, sob um regime de Direito Público portanto, consagrador de prerrogativas de supremacia e de restrições especiais -, instituído em favor dos interesses definidos como públicos no sistema normativo ${ }^{160}$.

(Grifo nosso).
\end{abstract}

159 Victor Rhein SCHIRATO (2012, p. 37-93) explica que a ideia de serviço público foi originariamente construída na França pela Escola do Serviço Público ou Escola de Bordeaux, tendo por finalidade prática apresentar o perímetro de intervenção do Estado, e, por consequência, os delineamentos do Direito Administrativo e da competência do Conselho de Estado Francês, conformando os ideais liberais vigentes à época com as demandas sociais amparadas pelas principais declarações de direito do período, espalhando-se em seguida para países outros europeus, sempre por uma necessidade concreta. Teria sido apenas no Direito Italiano do início do século XX - e, posteriormente, no Espanhol - que o serviço público se desenvolvera com o objetivo de legitimar a assunção, pelo Estado, da prestação de determinados serviços essenciais, garantindo ao ente político uma reserva originária de certas atividades consideradas relevantes para a coletividade. Explorando a evolução histórica da noção de serviço público no Brasil, ele afirma que, somente a partir da segunda metade da década de 1930, já sob a égide da Constituição de 1937, foi que, substituindo-se o modelo de inspiração norte americana da regulação contratual dos serviços de utilidade pública então vigente, encampa-se no Brasil a ideia de serviço público como uma atividade de titularidade estatal, cuja execução (e só) poderia ser transferida a particulares por meio de um ato oficial de delegação. Em suas palavras, eis que "as atividades que até então eram reguladas por serem de utilidade pública (i.e., de interesse coletivo) passam a ser incorporadas às funções públicas por constituir serviços públicos [...], de modo que a "ação estatal transfere-se da regulação (controle) destinada ao alcance de finalidades para a própria assunção da atividade". Nesse contexto, em forte aproximação com a doutrina francesa (sobretudo de Gaston Jèze), passou-se a entender que, justamente por ser próprio do Estado, o serviço público estaria submetido ao chamado regime jurídico de direito público, marcado por uma série de prerrogativas e obrigações especiais destinadas a assegurar o bom funcionamento do serviço. É justamente essa a chamada noção tradicional de serviço público, a qual teria se firmado no Brasil pelas seguintes razões: (i) influência de doutrinas estrangeiras (notadamente a francesa e a italiana); (ii) interesse do governo brasileiro de, em certo momento, expandir o seu controle sobre determinadas atividades; (iii) necessidade de justificar ações públicas em setores da economia; e (iv) concepções ideológicas. Como consequência dessa construção, ele afirma que, "no direito brasileiro, os serviços públicos (i) são vistos com forte apego ao seu aspecto formal (prestação pelo Estado ou por quem atue sob sua delegação); (ii) são construídos quase sempre como uma prerrogativa do Estado, ao invés de serem vistos como um direito dos cidadãos; e (iii) têm sua previsão constitucional lida e interpretada segundo concepções fincadas na doutrina, quando o correto seria precisamente o contrário". Prefere o Autor, então, encarar os serviços públicos como obrigações positivas impostas pela ordem jurídica ao Estado em prol da realização dos direitos fundamentais, ora lhe exigindo a prestação direta da atividade (inclusive por meio de delegatários), ora se conformando com uma atuação regulatória de garantia do Poder Público. A despeito dos substanciais argumentos levantados pelo Autor, não há como desconsiderar que, no Brasil, o conceito de serviço público tem assento constitucional, sendo encarado, nos termos do art. 175 da Constituição, como aquelas atividades reservadas à titularidade do Poder Público, apenas admitida a prestação pelos particulares mediante ato formal de delegação estatal, por concessão ou permissão.

${ }^{160}$ Em sentido próximo, José dos Santos CARVALHO FILHO (2013, p. 325), Maria Sylvia Zanella DI PIETRO (2012, p. 104), Marçal JUSTEN FILHO (2013, p. 731). 
Sucede que falta aos serviços sociais justamente essa titularidade exclusiva estatal dos serviços públicos ${ }^{161}$, na medida em que a iniciativa privada não depende de qualquer ato formal de delegação para incursionar no oferecimento dessas comodidades de marcado interesse coletivo, podendo prestar, por exemplo, educação, saúde e assistência social por direito próprio.

Nesse exato diapasão, leciona Juan Carlos CASSAGNE (1992, p. 44) que:

[...] Los servicios públicos propios se distinguen también de los llamados servicios sociales que presta el Estado en áreas tales como la cultura, salud pública, previsiòn social, cuya gestiòn suele encomendarse a òrganos $u$ entes administrativos, sin perseguirse fines de lucro. Esta actuaciòn estatal, para la realizaciòn de prestaciones que no poseen contenido econômico, no implica reemplazar ni sustituir la iniciativa privada que, respecto de estas actividades, continua regida por el principio de la libertad, sin perjuicio de lo cual - cuando la actividad la lleva a cabo el Estado - se aplican los princípios y normas propios de la funciòn administrativa.

É dessa mesma forma que Fernando Herren AGUILLAR (2011, p. 28-29) contrapõe os serviços sociais - que prefere chamar de funções de caráter social - com os serviços públicos, afirmando que, enquanto estes são regidos pelo art. 175 da Constituição Federal, tratando-se de atividades econômicas em regime de privilégio delegável mediante licitação, aqueles representam atribuições irrenunciáveis do Estado cujo regime não é o dos serviços públicos, pois, não organizados economicamente, não podem ser objeto de licitação pública (nem concessão ou permissão a particulares), não possuindo a função de viabilizar o equilíbrio entre receitas e despesas. Para ele, as funções públicas dividir-se-iam em exclusivas e não exclusivas, estando as sociais incluídas neste último subgrupo justamente por permitir a atuação dos particulares ${ }^{162}$.

\footnotetext{
${ }^{161}$ É importante perceber que a noção de serviço público apresentado pela doutrina dita tradicional - enquanto um núcleo de atividades próprio do Estado, em que se admite a prestação não estatal apenas através de instrumentos de delegação oficial - não é apenas doutrinário, possuindo assento constitucional, expresso de forma genérica no art. 175 da nossa Constituição Federal. A extensão da noção de serviço público àquelas atividades de marcado interesse coletivo abertas à iniciativa privada, simplesmente em razão do compartilhamento do mesmo substrato material - relevância para a sociedade, direcionamento para o atendimento das necessidades da comunidade - subverte o esquema constitucional, provocando perplexidades normativas insuperáveis, a exemplo da aplicação da responsabilidade civil objetiva estampada no $\S 6^{\circ}$ do art. 37 da Constituição às entidades de colaboração em geral. Nosso país, portanto, consagra um conceito constitucional de serviço público, cuja abrangência e limites não podem ser desconsiderados pelo intérprete do Direito.

162 Comentando a possibilidade de criação dos serviços públicos por via legislativa, deixando bem clara a prevalência na doutrina nacional pela noção de serviço público como produto de uma decisão política, Dinorá Adelaide Musetti GROTTI (2003, p. 101-106) menciona a postura de certos autores que chegam a sustentar que os serviços públicos somente seriam aqueles contidos no bojo da Constituição, podendo ser criados apenas por emenda constitucional - é justamente o caso de Fernando Herren AGUILLAR (2011, p. 07).
} 
Sem prejuízo, registre-se que, deixando de lado a pertinência estatal do conceito apresentado de serviço público ${ }^{163}$ e tomando como critério determinante o regime jurídico de direito público ${ }^{164}$ ao qual está submetido, boa parte da doutrina nacional entende que os serviços sociais são verdadeiros serviços públicos quando prestados pelo Estado, justamente pela incidência do regime exorbitante próprio da função administrativista, atraído pela presença do Poder Público na prestação da atividade.

É o posicionamento de Maria Sylvia Zanella DI PIETRO (2009, p. 831; 2012, p. 117), segundo a qual os serviços sociais seriam serviços públicos não exclusivos do Estado, ditos próprios quando desempenhados direta ou indiretamente pelo aparato estatal e impróprios $^{165}$ quando executados pelos particulares, caso em que, entretanto, ficam sujeitos à autorização e controle do Poder Público (atividade de polícia) ${ }^{166}$. Nesta linha de raciocínio,

${ }^{163}$ Espelhando o entendimento dominante na doutrina administrativista brasileira, Maria Sylvia Zanella DI PIETRO (2012, p. 107) afirma que, nos termos do art. 175 da Constituição Federal, o serviço público é sempre uma incumbência do Estado, sempre dele dependendo, daí porque: (i) a sua criação é feita por lei, em correspondência a uma opção estatal que interdita o acesso dos particulares (publicatio) e se legitima pela importância da atividade para a coletividade, cuja realização não parece conveniente ficar na dependência da iniciativa privada; e (ii) a sua gestão também incumbe ao Estado, que pode fazê-lo diretamente (por meio dos seus órgãos da Administração Direta) ou indiretamente (através dos instrumentos da concessão e permissão, ou de pessoas jurídicas criadas pelo Estado com essa finalidade).

${ }^{164}$ Referimo-nos, aqui, à teoria mais difundida no Brasil do regime jurídico de direito público, construída por Celso Antônio Bandeira de MELLO (2009) a partir do binômio principiológico da supremacia e indisponibilidade do interesse público: a primeira justificaria o conjunto de prerrogativas da Administração Pública; e a segunda imporia uma série de limitações exorbitantes à ação administrativa. Sem embargo, conforme anota Victor Rhein SCHIRATO (2012, p. 51), embora se reconheça um caráter especial da Administração Pública, ela não se submete a um regime jurídico único, numa apartação completa e estanque aquele de Direito Público e o de Direito Privado. Para o Autor, seu regime jurídico assumirá diferentes formas e critérios a cada momento, conforme assim estabeleça o direito positivo, de acordo com a função a ser desempenhada pelos órgãos e entidades administrativas. Esse mesmo raciocínio se aplica aos particulares, que se veem submetidos a uma série de restrições exorbitantes do regime de liberdade típico do chamado Direito Privado, com limitações e obrigações publicísticas ainda mais robustas quando no desempenho de atividades de interesse público, especialmente quando em regime de parceria com o Estado.

${ }^{165}$ Segundo Dinorá Adelaide Musetti GROTTI (2003, p. 119-120), de origem italiana (classificação de Arnaldo de VALLES, divulgada por Rafael BIELSA), a noção de serviços públicos impróprios (objetivos) se aproxima daquela francesa dos serviços públicos virtuais (inaugurada na jurisprudência do Conselho de Estado francês, no caso "Companhia Marítima da África Ocidental, em 05/05/1944), designando "atividades fundamentalmente privadas [leia-se, de titularidade estatal], não assumidas nem executadas pelo Estado, seja direta ou indiretamente, mas apenas por ele autorizadas, regulamentadas e fiscalizadas; dirigidas ao público para satisfazerem necessidades ou exigências de interesse geral ou público". Ainda de acordo com esta Autora (2003, p. 120-121), a doutrina estrangeira emprega diversa outras denominações, a exemplo de atividades individuais de interesse público (Sayagués LASO; Jorge H. Sarmiento GARCÍA); atividades privadas de interesse público (Manuel Maria DIEZ; Daniel Edgard MALJAR); serviços de interesse público (Fernando Garrido FALLA; Villar PALASÍ); empresas regulamentadas (JÉZE; Villegas BASAVILBASO); e atividades regulamentadas, disciplinadas ou programadas (Gaspar Ariño ORTIZ).

${ }^{166}$ Assim também, Celso Antônio Bandeira de MELLO (2009, p. 681; 2010, p. 284-285) e Sílvio Luís Ferreira da ROCHA (2006, p. 111). Encampando a visão tradicional de serviço público AGUILLAR (2011, p. 46-47) os diferencia justamente das atividades que constituem o exercício do poder de polícia, afirmando que, enquanto os serviços públicos correspondem ao oferecimento de uma comodidade fruível ao particular, o exercício do poder de polícia não implica senão a sujeição do particular a um dever ou a um ônus, no interesse da segurança pública, da satisfação de interesses públicos de limitar a liberdade individual, caracterizando uma função pública. 
ao revés, quando executadas [por direito próprio] pelos particulares, os serviços sociais seriam atividades privadas [sem pertinência estatal] de interesse coletivo, submetidas à regência do Direito Privado, em que vigora a autonomia e liberdade, sem prejuízo da submissão a intensas manifestações do poder de polícia, que lhes impõe os limites das garantias fundamentais constitucionalmente asseguradas (Dinorá Adelaide Musetti GROTTI, 2003, p. 126-127) ${ }^{167}$.

Nessa mesma linha de raciocínio, Alexandre Santos de ARAGÃO (2008, p. 182185) acrescenta que a Constituição Federal de 1988 teria adotado essa discriminação, uma vez que trata dos serviços de saúde prestados pelo Estado como serviços públicos de saúde (art. 198), mas se vale da nomenclatura serviços de relevância pública quando deseja abranger os casos em que a saúde é prestada pela iniciativa privada (art. 197). Nesta perspectiva, o Autor prefere a expressão serviços compartidos, os quais, quando prestados pelos particulares, seriam atividades econômicas privadas, eventualmente de interesse público ou regulamentadas, e, quando explorados pelo Poder Público, seriam serviços públicos sociais, não se confundindo com os demais serviços públicos pela inexistência de reserva de titularidade estatal.

Esse também é o entendimento do Ministro do STF Ayres Britto, que, em 2011, no julgamento do mérito da referida ADI n $n^{\circ}$ 1.923/DF, afirmou que existem serviços públicos de titularidade estatal exclusiva e serviços públicos de titularidade mistamente pública e privada (saúde, educação e ensino, cultura, previdência social, etc.), esclarecendo que estas últimas, "se prestadas pelo Setor Público, são atividades públicas de regime jurídico igualmente público. Se prestadas pela iniciativa privada, óbvio que são atividades privadas, porém sob o timbre da relevância pública""168.

\footnotetext{
${ }^{167}$ Dinorá Adelaide Musetti GROTTI (2003, p. 126-129), contudo, seguindo os ensinamentos de Gaspar Arinõ ORTIZ, rechaça a classificação serviços públicos próprios e serviços públicos impróprios, aduzindo que "todas as atividades consideradas pela doutrina como serviços públicos impróprios, objetivos ou virtuais, não são verdadeiros serviço públicos porquanto em nenhuma delas há publicatio da atividade (reserva de titularidade em favor do Estado), nem se exige, a rigor, concessão...". Ademais, pensa a Autora que o esgarçamento da noção de serviços públicos para abranger as atividades sociais traria o risco de que a mesma venha a "perder o seu sentido descritivo de atividade prestacional da Administração", tornando-se inservível, comprometendo, ainda, a distinção entre o público e o privado.

${ }_{168}$ É sempre necessário muito cuidado com o emprego dos qualificativos público e privado, especialmente quando se estuda o tema do presente trabalho, marcado pela mistura do estatal com o não estatal, do regime público com o de direito privado. É que, como já esclarecido, nem sempre tais palavras são utilizadas com referência ao regime jurídico (o que, em Direito, se mostra impróprio), sendo assim também utilizado num sentido material (para distinguir atividades econômicas em sentido estrito, de produção de bens e serviços para o mercado e indústria, sem repercussão imediata/direta no atendimento das necessidades sociais, de atividades de interesse coletivo) e num sentido subjetivo (para diferenciar estatal de não estatal).
} 
Com o merecido respeito, ousamos discordar dessa definição da natureza jurídica duma atividade a partir da identificação do seu prestador, eis que, como visto no início do presente trabalho, a única categorização que faz sentido pro Direito é aquela que tem por critério classificatório o regime jurídico, não sendo certo subordinar a natureza jurídica duma atividade à qualidade do sujeito que a exercita ${ }^{169}$.

Para nós, a correspondência identificada entre o estatuto jurídico dos serviços públicos e aquele dos serviços sociais prestados pelo Estado se explica: a uma, como bem explica Paulo Eduardo Garrido MODESTO (2005, p. 22), pela presença do corpo estatal, que atrai, por si só, o regime jurídico próprio da função administrativa; a duas, por causa do compartilhamento do substrato material de utilidade/relevância à coletividade, que reclama do Estado, instrumento de realização dos interesses públicos que é, a garantia da sua oferta adequada a toda a sociedade, havendo verdadeiro dever do ente público de assegurar a prestação geral, acessível, contínua e eficiente dessas comodidades sociais ${ }^{170}$.

Diferentemente, visando a superar as perplexidades que surgem da identificação dos serviços sociais com os serviços públicos - ainda que por meio da diferenciação entre serviços públicos próprios e impróprios -, parte da doutrina brasileira defende a categoria jurídica própria dos serviços de relevância pública, entendidas, de acordo com Paulo Eduardo Garrido MODESTO (2005, p. 19) como:

[...] atividades consideradas essenciais ou prioritárias à comunidade, não titularizadas pelo Estado [não sujeitas ao privilégio ou monopólio estatal], cuja regularidade, acessibilidade e disciplina transcendem necessariamente a dimensão

\footnotetext{
${ }^{169}$ Paulo Eduardo Garrido MODESTO (2005, p. 22) observa que a adoção desse critério subjetivo mostra-se “[...] incoerente com a tese predominante na doutrina brasileira de se buscar a identidade própria da atividade de serviço público na identificação do regime jurídico especial da atividade, não do sujeito que por ela responde".

170 Victor Rhein SCHIRATO (2012, p. 53) leciona que, sofrendo influências de Gaston Jèze, a doutrina brasileira define o serviço público a partir do seu regime jurídico especial, dum "conjunto de obrigações especiais destinadas a assegurar o funcionamento do serviço". Esse regime jurídico do serviço público leva em conta a vinculação do seu objeto com os interesses públicos e, por conseguinte, a necessidade de assegurar a sua adequada prestação à coletividade (art. 175, par. único, IV, da Constituição), sendo orientado, de acordo com Diogo de Figueiredo MOREIRA NETO (2014, p. 471) pelos princípios da generalidade, continuidade, regularidade, eficiência, atualidade, segurança, cortesia e modicidade. Esse regime jurídico da atividade de serviço público não corresponde propriamente ao regime jurídico próprio das estruturas administrativas, este, sim, decorrente da presença do corpo estatal, que atua conforme os princípios constitucionais da legalidade, impessoalidade, moralidade, publicidade e eficiência (art. 37, caput). Traçando um paralelo com o regime jurídico dos serviços sociais em geral, apenas possível em razão do compartilhamento da mesma base objetiva dos serviços públicos (comodidades essenciais à coletividade), temos que o Estado também atuará pela garantia do seu bom funcionamento, impondo obrigações restritivas da liberdade dos particulares para assegurar a sua adequação, aproximando-o ainda mais do regime jurídico do serviço público.
} 
individual, obrigando o Poder Público a controlá-las, fiscalizá-las e incentivá-las de modo particularmente intenso ${ }^{171}$.

A par dos serviços públicos e das atividades econômicas em sentido estrito ${ }^{172}$, os serviços de relevância pública comporiam uma categoria jurídica própria ${ }^{173}$, correspondentes a setores de interesse público que, conquanto livres à iniciativa privada, se sujeitam a uma tutela especial por parte do Poder Público, em nome da realização e proteção das necessidades coletivas e direitos fundamentais neles implicados, tratando-se de serviços de interesse coletivo ou atividades de conteúdo social relevante (Paulo Eduardo Garrido MODESTO, 2005, p. 02-04; 2006, p. 05-07).

Representam, pois, aquelas comodidades ou utilidades essenciais à coletividade sujeitas tanto à prestação estatal quanto à não estatal, diferenciando-se: (i) das atividades econômicas em sentido estrito, que, em princípio, nos termos do art. 173 da atual Constituição Brasileira, estão acometidas ao mercado privado, somente podendo ser executadas pela Administração Pública por imperativos da segurança nacional, em razão de relevante interesse público ou, ainda, nos casos expressamente previstos na Lei Maior de

${ }^{171}$ O Autor (2006, p. 05 e 07) destaca se tratar de serviços sociais de interesse coletivo, que designam aquelas atividades de conteúdo social relevante. A aceitação da noção dos serviços de relevância pública é explicada ainda pela sua referência textual nos arts. 129, II, e 197, da Constituição Federal de 1988.

${ }^{172}$ Maria Sylvia Zanella DI PIETRO (2012, p. 115) explica que as atividades econômicas são de três tipos: (a) atividades econômicas em sentido estrito: aquelas comerciais ou industriais abertas à iniciativa privada, que o Estado somente pode executar nos termos do art. 173 da Constituição Federal, por motivo de segurança nacional ou relevante interesse coletivo, como mecanismo de intervenção direta no domínio econômico, atuando na esfera de ação dos particulares e sujeitando-se obrigatoriamente ao regime das empresas privadas, salvantes algumas derrogações previstas em lei; (b) atividades econômicas monopolizadas pelo Estado: como é o caso da exploração de petróleo, de minas e jazidas, de minérios e minerais nucleares (arts. 176 e 177 da Constituição Federal); e (c) serviços públicos comerciais e industriais: atividades econômicas assumidas pelo Estado como serviço público, sujeitos ao regime do 175 da Constituição Brasileira, que determina a sua execução direta pelo Estado ou indireta por meio de concessão ou permissão, como é o caso dos serviços de energia elétrica, telecomunicações e outros serviços previstos nos arts. 21, XI e XII, e 25, § $2^{\circ}$, da Lei Maior de 1988 - a Autora (2012, p. 106) defende a referida noção tradicional de serviço público, enquanto "toda atividade material que a lei atribui ao Estado para que a exerça diretamente ou por meio de seus delegados, com o objetivo de satisfazer concretamente às necessidades coletivas, sob o regime jurídico total ou parcialmente público".

${ }^{173}$ Comentando o referido Anteprojeto de Reforma da Administração Pública Brasileira, Maria Sylvia Zanella DI PIETRO (2010, p. 250) acompanha o entendimento de Eros Roberto GRAU (1992, p. 21) no sentido de que os serviços de relevância pública abrangeriam todas as atividades de interesse público, tanto prestadas pelo Estado (encarados como serviço público não exclusivos) quanto pela iniciativa privada (chamados de serviços sociais). Na verdade, a Autora corresponde os serviços de relevância pública aos serviços sociais, afirmando se tratar de atividades de interesse público, que atendem a necessidades coletivas, mas que estão abertas à iniciativa privada. A única particularidade é que ela os chama de serviços públicos não exclusivos quando prestados pelo Estado, por entender que, embora não haja reserva de titularidade estatal - estando livres à prestação privada -, os serviços sociais, quando executados pelo Estado, estão sujeitos ao regime de direito público, sem qualquer distinção dos serviços públicos tradicionalmente compreendidos. Conclui a Autora que todas as atividades de relevância pública poderiam ser prestadas em parceria com o Estado, desde que seja celebrado o chamado contrato de colaboração. 
$1988^{174}$, não se dirigindo, ao menos de forma imediata, ao atendimento das necessidades sociais; e (ii) da noção tradicional dos serviços públicos, que, de acordo com Márcia PELEGRINI (2007, p. 53-55), designa setores da economia submetidos à intitulada publicatio, reservados que estão à titularidade estatal, podendo os particulares neles ingressar apenas por ato de delegação, nos termos do art. 175 da nossa Constituição Federal.

Assim sendo, dois são os elementos caracterizadores dos serviços de relevância pública: (i) não sujeitos à reserva de exclusividade estatal, eles podem ser executados sponte propria pelos particulares, independentemente de qualquer ato formal de delegação da Administração Pública; (ii) enquanto atividades de interesse público, extrapolam as conveniências ou proveitos individuais, tratando-se de comodidades essenciais a toda a coletividade que, justo por isso, se sujeitam a um regime jurídico especial em que o Estado exerce o irrenunciável papel de garantidor do seu acesso contínuo e adequado à sociedade.

À vista da titularidade concorrente do Estado e da iniciativa privada nos serviços de relevância pública, Paulo Eduardo Garrido MODESTO (2011, p. 16) observa serem eles o campo ideal para a celebração de parcerias entre organizações estatais e não estatais, a exemplo dos contratos de colaboração nos serviços sociais:

Os serviços de relevância pública não são serviços públicos, mas também não são atividades de exploração econômica. Constituem zona jurídica intermediária, rol de atividades que dispensa título especial de autorização tanto para o Estado quanto para os particulares, mas que cumpre papel relevante no fornecimento de utilidade [sic] vitais para os cidadãos, sendo especialmente protegida na Constituição Federal (v.g., art. 129, II). Trata-se de domínio em que a atividade de execução direta de serviços e a atividade de fomento administrativo, mediante outorga de títulos especiais, apoio financeiro e acordos de parceria encontra lugar privilegiado para coexistir, rompendo-se em definitivo a dicotomia de soma zero que isolava a atuação dos particulares e do Estado em zonas distintas e mutuamente excludentes.

O Autor (2011, p. 19) ressalta ainda a imprescindibilidade do conceito constitucional de serviços de relevância pública (art. 129, II, e 197, caput), que permitiria a aplicação adequada, em extensão e intensidade, do Direito Público aos vínculos de colaboração pactuados entre entidades privadas sem fins lucrativos e o Poder Público.

\footnotetext{
${ }^{174}$ Cuida-se das mencionadas atividades econômicas monopolizadas pelo Estado, a exemplo da exploração de jazidas de petróleo, gás natural e outros hidrocarbonetos fluídos, conforme estabelece o art. 177 do texto constitucional brasileiro.
} 
Odete MEDAUAR (2003, p. 118) acrescenta que a categoria dos serviços de relevância pública se inspira nas public utilities dos países da common law, traduzindo-se em "atividades que se encontram (are affected with) com o interesse público e por isso sujeitam-se a um controle dos preços (para que se tenha um preço reasonable), ao controle da qualidade dos serviços e outros controles, realizados, de regra, por agências reguladoras independentes".

Por fim, anote-se que o parágrafo único do artigo 74 do referido Anteprojeto de Reforma da Administração Pública Federal e Entidades Paraestatais e de Colaboração encampa a correspondência dos serviços sociais com os serviços de relevância pública, assim chamando o objeto dos contratos de colaboração, arrolando atividades, ações ou programas de utilidade pública que podem ser prestados pelo Estado, pelos particulares ou por ambos através desses vínculos de parceria, deixando aberta a possibilidade de outros tantos serem estabelecidos em leis extravagantes (Maria Sylvia Zanella DI PIETRO, 2010, p. 251 ) 175.

Sem prejuízo da nossa predileção pela expressão serviços de relevância pública, não podemos deixar de reconhecer que, independentemente do nomen iuris que se atribua ao objeto dos contratos de colaboração, cuida-se de um setor público - aqui, em sentido objetivo, material, alusivo à sua marcada utilidade coletiva -, livre ao ingresso da iniciativa privada, que as pode desempenhar por direito próprio, isto é, sem qualquer instrumento de delegação estatal, tanto de forma autônoma quanto mediante parceria com o Poder Público ${ }^{176}$.

Incursionando no regime jurídico dos serviços sociais, cumpre reconhecer que, qualquer que seja o rótulo dado aos serviços prestados no âmbito dos contratos de colaboração, estar-se-á diante de atividades submetidas a um regime jurídico especial, justificado pela pertinência coletiva/pública das atividades desenvolvidas e construído a partir da atividade normativa do Estado (legal e, dentro dos seus limites, infralegal ${ }^{177}$ ), esta

\footnotetext{
${ }^{175}$ Maria Sylvia Zanella DI PIETRO (2010, p. 249) considera que o Anteprojeto entendeu por bem separar as ideias de vínculo de colaboração e de contrato de colaboração, de modo a divisar, de um lado, o que pode ser objeto de liame jurídico entre as entidades de colaboração e os entes estatais - isto é, os serviços de relevância pública -, e, de outro, o instrumento jurídico adequado a esse desiderato - convênio, contrato de gestão, termo de parceria, etc..

176 É exatamente por esse motivo que identificamos na doutrina nacional designações genéricas, pouco comprometedoras em termos jurídicos, para as atividades realizadas (em parceria ou não) pelas entidades da sociedade civil sem fins lucrativos, a exemplo de atividades voltadas ao bem comum (Silvio Luís Ferreira da ROCHA, 2006, p. 21), atividades de interesse público (Dinorá Adelaide Musetti GROTTI, 2012, p. 93; Silvio Luís Ferreira da ROCHA, 2006, p. 91), atividades sensíveis (Diogo de Figueiredo MOREIRA NETO, 2006, p. 389-391)

${ }^{177}$ A disciplina normativa dos serviços de relevância pública, tal qual ocorre com os serviços públicos, pode tranquilamente ser objeto do poder administrativo normativo, vindo disciplinada setorialmente pela própria
} 
que se desenvolve à luz de cada setor social específico, tendo em vista as reais carências da sociedade e os objetivos específicos que se pretende alcançar ${ }^{178}$.

Não é por outra razão que, defendendo a utilidade da locução serviços de relevância pública, Paulo Eduardo Garrido MODESTO (2005, p. 19-20) afirma que, embora eles estejam livres à atuação privada, “a lei ordinariamente impõe que a fiscalização e regulação dessas atividades pelo Poder Público seja minudente e tutelar", de modo a assegurar os princípios constitucionais, notadamente o da dignidade da pessoa humana. Para ele, devem incidir nesse campo os princípios frequentemente associados no Direito Comparado aos denominados serviços de interesse geral, em especial as obrigações de não discriminar usuários (igualdade), de cobrar preços razoáveis ou acessíveis (acessibilidade) e de atuar de modo regular (continuidade) ${ }^{179}$.

Embora não pareça exigir a construção legal do estatuto jurídico dos serviços de relevância pública, Odete MEDAUAR (2003, p. 120) também lhe reconhece um regime jurídico excepcional, aproximando-o de conceitos engendrados no âmbito da Comunidade Europeia a partir do final do século $\mathrm{XX}$ - serviço público, serviço de interesse econômico geral, serviço de interesse geral e serviço universal -, especialmente dos tais serviços de interesse geral, assim considerados pelas autoridades públicas e submetidos a obrigações específicas de serviço público ${ }^{180}$.

A despeito de existir claro paralelismo entre o regime jurídico dos serviços públicos e aquele dos serviços de relevância pública, nomeadamente porque eles compartilham de mesma base objetiva, tratando-se de essencialidades/comodidades/utilidades do corpo

\footnotetext{
Administração Pública. Em respeito ao princípio fundamental do Estado de Direito, contudo, essa atividade administrativa normativa possui os seus limites definidos pela lei, não podendo diretamente criar, modificar e extinguir direitos e obrigações.

${ }^{178}$ Para não avançar no exame do regime jurídico dos contratos de colaboração, a necessidade de definição legal do estatuto normativo dos serviços de relevância pública será esclarecida no Capítulo 2 da Parte II desta dissertação, quando se analisará os fundamentos constitucionais desse entendimento, o qual se aplica, inclusive, aos serviços públicos. Nada obstante, adiante-se ser justamente a exigência de que quaisquer obrigações publicísticas sejam fixadas em lei que descontrói a ideia dum regime jurídico comum/monobloco dos serviços de relevância pública e mesmo dos serviços públicos.

${ }^{179}$ Neste momento, contudo, o Autor parece opor aos serviços de relevância pública um conjunto de princípios apriorísticos, independentes da disciplina normativa estatal, o que contraria o entendimento defendido na presente dissertação.

${ }^{180}$ Sobre esses conceitos, verificar o Glossário da Comunidade Europeia (Comunicação da Comissão de 1996), disponível na internet em: <www.europa.eu.int/scadplus/leg/pt/cig/g4000.htm>. Comentando esse flerte com o Direito Europeu, Paulo Eduardo Garrido MODESTO (2005, p. 20) adverte que "a babel conceitual europeia não nos interessa de forma imediata, pois aglutina conceitos de gradação sucessiva e, por isso, parcialmente superpostos, atividades de serviço público abertos à competição, serviços monopolistas e também serviços sociais, o que não encontra abrigo em nossa Constituição Federal, a qual não possui superposições equivalentes".
} 
social, permanecemos fixos no sentido de que essa unidade de sentido ${ }^{181}$ tão somente atrai uma disciplina jurídica mais intensa por parte do Estado-instrumento ${ }^{182}$, a garantir, por meio de obrigações publicísticas, a realização dos interesses públicos envolvidos e a proteção dos direitos fundamentais, inclusive através da imposição de monopólios ou privilégios estatais, transformando meros serviços de relevância pública em verdadeiros serviços públicos.

Essa unidade [objetiva] de sentido impõe ao Estado, outrossim, verdadeiro dever de garantia da boa prestação dessas atividades, a qual, não alcançada pela ação dos particulares, deve ser encampada pelo Poder Público, na medida em que ele não passa dum instrumento de realização dos interesses coletivos, estando a serviço da sociedade ${ }^{183}$. Podese falar, inclusive, em sindicabilidade desse dever estatal de assegurar a boa execução dos serviços sociais.

Temos, enfim, que os serviços sociais correspondem juridicamente aos serviços de relevância pública, estando sujeitos, senão por isso, a um regime jurídico exorbitante do Direito Comum, restritivo da liberdade de ação dos particulares, na medida em que a sua pertinência com as necessidades básicas da sociedade reclama uma disciplina normativa intensa do Estado, a impor à iniciativa privada de interesse público obrigações positivas de concretização dos interesses públicos.

\footnotetext{
${ }^{181}$ Alexandre do Santos de ARAGÃO (2008, p. 156-157) defende a maior operabilidade daquilo que ele intitula conceito restrito de serviço público, que inclui tanto os serviços públicos tradicionalmente compreendidos enquanto uma reserva de exclusividade estatal -, quanto os serviços de relevância pública - abertos tanto à iniciativa privada e a que prefere se referir como serviços compartidos -, porquanto englobante de atividades que, muito embora não tenham regimes jurídicos idênticos, possuiriam um mínimo satisfatório de pontos em comum, uma unidade de sentido, isto é, um regime jurídico mínimo comum significativo.

${ }^{182}$ Todavia, conforme será exposto no Capítulo 2 da Segunda Parte do presente estudo, entendemos não se tratar de mero exercício do poder de polícia do Estado, compatibilizador dos interesses privados com os públicos.

${ }^{183}$ Diogo de Figueiredo MOREIRA NETO $(2008$, p. 11) explica que a razão de ser do ente estatal é servir à proteção e à realização dos direitos fundamentais, de modo que a Teoria Funcional do Direito se volta à obtenção de resultados que efetivamente e não apenas intencionalmente ou retoricamente satisfaçam a essa vocação. Para o Autor, é o atendimento das necessidades concretas das pessoas a razão de ser constitucional da atividade administrativa, sendo o desatendimento dessas necessidades, ao revés, uma violação aos comandos constitucionais que instituem as regras de competência.
} 


\section{SEGUNDA PARTE: DO REGIME JURÍDICO DOS CONTRATOS DE COLABORAÇÃO}

\section{DO REGIME DE SELEÇÃO DAS ENTIDADES DE COLABORAÇÃOO}

Como explorado na primeira parte da presente dissertação, os contratos de colaboração, enquanto instrumento de fomento administrativo, viabilizador da transferência de recursos públicos a entidades da sociedade civil sem fins lucrativos, têm a sua celebração sujeita aos princípios constitucionais da Administração Pública, especialmente os da legalidade, impessoalidade, moralidade, publicidade e eficiência (art. 37, caput, da Constituição).

Por conseguinte, a seleção das entidades de colaboração deve estar sujeita a procedimento objetivo de concorrência, no qual, sob a perspectiva dos potenciais interessados, seja-lhes assegurado o direito de disputar em pé de igualdade a oferta de recursos públicos [incontornavelmente limitados] para o desempenho colaborado de atividades sociais com o Poder Público - princípio da isonomia; e, sob a ótica da Administração Pública e dos cidadãos em geral, escolha-se aquele concorrente mais habilitado à realização do interesse público que norteia a cooperação pretendida - princípio da eficiência ${ }^{184}$.

Nesse exato sentido, comentando a escolha de OSCIPs, Gustavo Henrique Justino de OLIVEIRA e Fernando Borges MÂNICA (2005, p. 19) afirmam que a exigência de certame objetivo proporciona isonomia no tratamento das organizações da sociedade civil de interesse público que atuem em áreas afins e busca maior eficiência no oferecimento do serviço à sociedade.

Todavia, não há que se confundir esse procedimento de seleção de entidades de colaboração com o instituto da licitação pública, imposto pelo inciso XXI do art. 37 da Constituição Federal às contratações de obras, serviços, compras e alienações pela Administração Pública sob a lógica retributiva/remuneratória, em que o contratante público

\footnotetext{
${ }^{184}$ Referindo-se ao procedimento do chamamento público do Decreto Federal no 6.170/2007, Carolina Caiado LIMA (2010, p. 109) anota que ele garante a observância não apenas do princípio da isonomia ou igualdade, também permitindo à Administração avaliar a qualificação técnica e financeira da entidade privada proponente, bem como as suas condições operacionais, garantindo, enfim, a eficiência administrativa.
} 
paga, com garantia do equilíbrio econômico financeiro, pela prestação do contratante privado, tratando-se, pois, dos tradicionais contratos administrativos, cuja disciplina legal geral é dada pela Lei Federal $n^{\circ} 8.666 / 1993^{185}$.

Como bem observa Janaina SCHOENMAKER (2011, p. 60), a doutrina nacional tradicionalmente distingue os acordos convencionais celebrados pela Administração dos contratos administrativos justamente com o objetivo precípuo de afastar a necessidade de realização de procedimento licitatório para a sua celebração, liberando esses ajustes colaborativos da rigidez das disposições da Lei Federal nº 8.666/1993, que, conforme previsto no seu art. 116, se aplicariam aos convênios em sentido amplo apenas naquilo que couber $^{186}$.

É o caso de Gustavo Henrique Justino de OLIVEIRA e Fernando Borges MÂNICA (2005, p. 19), que entendem inaplicáveis a Lei Geral de Licitações aos termos de parceria celebrados com as organizações da sociedade civil de interesse público por [supostamente] não se tratar de contratação administrativa, mas duma nova modalidade de acordo

185 Não se trata de entendimento manso na doutrina brasileira, contudo, existindo vozes abalizadas que defendem a necessidade de procedimento licitatório para a seleção de entidades de colaboração. É o caso de Silvio Luís Ferreira da ROCHA (2006, p. 92), para quem o concurso de projetos previsto no art. 23 do Decreto Federal 3.100/1999 não é capaz de garantir a observância dos princípios da igualdade, impessoalidade e moralidade, impostos às organizações da sociedade civil de interesse público pelo próprio inciso I do art. $4^{\circ}$ da Lei Federal $n^{\text {o }}$ 9.790/1999. Da mesma forma, Odete MEDAUAR (1995, p. 83) assevera que "se a Administração quiser realizar convênio para resultado e finalidade que poderão ser alcançados por muitos particulares, deverá realizar licitação". É necessário considerar, contudo, que o Decreto Federal n 7.568/2011 alterou a redação do art. $4^{\circ}$ do Decreto Federal $n^{\circ} 6.170 / 2007$, exigindo que a celebração de convênios e contratos de repasse com entidades privadas sem fins lucrativos para o repasse de recursos da União sejam precedidos de chamamento público, procedimento de seleção objetiva simplificado, espancando de vez a celeuma em torno da necessidade de realização de licitação pública, esvaziando o previsto na aludida Instrução Normativa. Finalmente, defendendo a natureza contratual dos convênios administrativos, Gustavo Alexandre MAGALHÃES (2012, p. 230-234) entende que a sua celebração se sujeita aos arts. 37, XXI, e 22, XXVII, da Constituição Federal, não se admitindo que as modalidades simplificadas de seleção de entidades de colaboração previstas em atos normativos infralegais (chamamento público, previsto no art. $4^{\circ}$ do Decreto Federal $n^{\circ} 6.170 / 2007$ e art. $8^{\circ}$ da Portaria Interministerial $n^{\circ} 507 / 2011$, e concurso de projetos, disciplinado pelo art. 23 do Decreto Federal $n^{\circ} 3.100 / 1999$ e art. $8^{\circ}$ da Portaria Interministerial MP/MF/CGU n ${ }^{\circ}$ 507/2011) afastem a incidência da Lei Federal $n^{\circ}$ 8.666/1993, eis que, diante dos referidos dispositivos constitucionais, somente se admite a criação de modalidades licitação por lei formal editada pela União. Para o Autor, então, aplicando-se uma interpretação conforme à Constituição, deve-se conceber o chamamento público e o concurso de projetos como aplicação da licitação na modalidade concurso contida no art. $2^{\circ}, \S 4^{\circ}$, da Lei Federal $n^{\circ}$ $8.666 / 1993$.

${ }^{186}$ Igualmente, Carlos Ari SUNDFELD e Rodrigo Pagani de SOUZA (2013, p. 44) explicam que chamar de convênio as modernas parcerias públicas com o terceiro setor configura verdadeiro apelido de fuga, explicado, a par da inércia da tradição no uso de expressões correntes no ambiente jurídico, justamente pela "[...] necessidade gerencial de fuga do regime licitatório ditado pelo defasado Estatuto das Licitações e Contratos Administrativos brasileiro (Lei 8.666/1993)"'. Também Gustavo Alexandre MAGALHÃES (2012, p. 230) constata que a suposta natureza não contratual dos convênios é o principal argumento da doutrina dominante nacional para afastar a realização de licitação prévia como condição para a sua celebração. 
administrativo, cujo objetivo consiste em fomentar a prestação de serviços públicos sociais e a promoção de direitos fundamentais.

Partindo da distinção entre contratos e convênios, nomeadamente da ausência de obrigações recíprocas que existiria nesta segunda modalidade de ajuste celebrada pela Administração, Maria Sylvia de Zanella DI PIETRO (2005, p. 310-314) sustenta que o convênio não se submete à licitação pública em razão do próprio teor do art. $2^{\circ}$ da Lei Federal $n^{\circ} 8.666 / 1993$, que restringe a aplicação da lei às contratações de obras, serviços, compras, alienações, concessões e permissões e locações, e oferece, em seu par. único, conceito de contrato excludente da noção de convênio. Ela explica essa exclusão legal na inviabilidade de competição [supostamente] ínsita ao seu regime de mútua cooperação (sob variadas formas, como repasse de verbas, uso de equipamentos, de recursos humanos, de imóveis e de know-how), não se cogitando de preço ou remuneração que admita disputa ${ }^{187}$. A Autora (2015, p. 237) assevera, inclusive, que, se os convênios tivessem natureza contratual, não haveria necessidade da previsão contida no caput do art. 116 da Lei Federal no 8.666/1993 (“Aplicam-se as disposições desta Lei, no que couber, aos convênios, acordos, ajustes e outros instrumentos congêneres celebrados por órgãos e entidades da Administração"), porque a aplicação da Lei já decorreria dos seus arts. $1^{\mathbf{o}}$ e $2^{\mathbf{0} 188}$.

Nada obstante, consoante já explicado, preferimos defender que o inciso XXI do art. 37 da Constituição - e, por conseguinte, as disposições da Lei Federal no 8.666/1993 189

\footnotetext{
${ }^{187} \mathrm{O}$ argumento da inviabilidade de competição falece diante daquelas parcerias em que haja transferência de recursos públicos financeiros ou patrimoniais. É que, sendo os recursos públicos essencialmente escassos, a Administração, vinculada que está constitucionalmente aos princípios da isonomia, impessoalidade, moralidade e eficiência, deve assegurar a todos os interessados o direito de disputar o emparceiramento com o Estado na realização de atividades sociais, buscando, outrossim, a cooperação com as entidades da sociedade civil sem fins lucrativos mais aptas à realização dos objetivos coletivos perseguidos, dispendendo o dinheiro público segundo a máxima realização do interesse público. Nesse mesmo diapasão, confiram-se os votos dos Ministros Ayres BRITTO e Luiz FUX no julgamento do mérito da ADI no 1.923/DF. Sem embargo, mesmo nos casos em que não haja entrega de valores ou bens ao ente fomentado, em verdadeira inviabilidade de competição, os princípios da moralidade e da eficiência administrativas, associados ao princípio setorial da adequação dos serviços públicos, reclamam que a Administração não estimule a prestação de serviços sociais de baixa qualidade. Nessa linha de raciocínio, como bem colocado por Fernando Dias MENEZES DE ALMEIDA (2012, p. 245), "Mesmo se tratando de entidades sem fins lucrativos a se conveniarem, e também de situações em que a Administração não perceba benefício econômico, pode haver critérios técnicos para se avaliar comparativamente a qualidade de potenciais interessados em um convênio". Registre-se, contudo, a posição de Celso Antônio Bandeira de MELLO (2009, p. 666), que, focado na proteção do princípio da igualdade, entende que somente deverá ser realizado procedimento objetivo de seleção de entidades de colaboração quando não for possível a celebração da parceria com todas as entidades privadas sem fins lucrativos interessadas.

${ }^{188}$ Sem embargo, a Autora (2015, p. 300) entende que esses procedimentos objetivos simplificados de seleção são espécie de licitação, que simplesmente são regidos por legislação própria.

${ }^{189}$ Não é de se desconsiderar, outrossim, que a própria redação dos arts. $1^{\circ}$ e $2^{\circ}$ da Lei Geral de Licitações não abrange os acordos de mútua cooperação (convênios administrativos).
} 
- não se aplicam aos convênios administrativos não porque estes não possuem natureza contratual, mas em razão de tal dispositivo constitucional se referir a forma específica de contratação inconfundível com os acordos ou ajustes de cooperação, na medida em que trata da aquisição de obras, serviços, compras e alienações em favor da própria Administração Pública, que retribui/remunera as prestações do contratado privado, inclusive com a preservação do equilíbrio econômico-financeiro ("mantidas as condições efetivas da proposta") ${ }^{190}$.

Independentemente das controvérsias doutrinárias ainda existentes sobre o tema, fato é que o nosso Direito Positivo caminhou no sentido de não submeter a celebração dos contratos de colaboração à licitação pública [tal qual compreendida no inciso XXI do art. 37 da Constituição e na Lei federal $\left.n^{\circ} 8.666 / 1991\right]^{191}$. Com efeito, para todas as espécies de contratos de colaboração admitidas em âmbito federal, a atual legislação brasileira considera suficiente a realização de procedimento objetivo simplificado de seleção das entidades privadas parceiras do Estado no setor social. Senão, vejamos:

Os convênios ${ }^{192}$ e contratos de repasse têm a sua celebração condicionada à realização do tal chamamento público, certame simplificado que, com base em critérios objetivos, visa a aferir a qualificação técnica e a capacidade operacional de entidades não estatais sem fins lucrativos que pretendam colaborar com o Poder Público na execução de programas, projetos ou atividades sociais ${ }^{193}$. Trata-se de medida moralizadora prevista no

\footnotetext{
${ }^{190}$ Reconhecendo a natureza contratual das modernas parcerias públicas com o terceiro setor, Carlos Ari SUNDFELD e Rodrigo Pagani de SOUZA (2011, p. 45) fundamentam a sua não submissão à Lei Geral de Licitações na dispensa que é por vezes prevista na lei como legítima política de Estado e na inexigibilidade decorrente da incompatibilidade da Lei Federal $n^{\circ}$ 8.666/1993 como objeto desses ajustes colaborativos. Explica Carlos Ari SUNDFELD (2011, p. 22) que o modelo da Lei Federal $n^{\circ}$ 8.666/1993 pode ser bom para as contratações de empreitadas, mas não se ajusta tão bem aos contratos de parceria, na medida em que: (i) o objetivo não é obter a proposta mais barata, e sim eleger a entidade que melhor encarne o perfil público; (ii) os arranjos de parceria atribuem aos particulares responsabilidades de gestão, e seu bom exercício exige liberdade de meios, incompatível com as prescrições da Lei Geral de Licitações.

${ }^{191}$ A despeito do já referido art. 27 da Instrução Normativa STN nº 01/1997, que submetia a firmatura de convênios à realização do procedimento licitatório contido na Lei Federal nº 8.666/1993, não mais se aplicando em virtude da Portaria Interministerial MP/MF/CGU no 127/2008 (revogada pela Portaria Interministerial MP/MF/CGU n ${ }^{\circ}$ 507/2011) e da previsão do chamamento público contida no Decreto Federal no 6.170/2007.

${ }^{192}$ Mais uma vez, observe-se que, embora todos os acordos de cooperação nos serviços sociais travados entre a Administração Pública e as organizações da sociedade civil sem fins lucrativos se insiram na noção ampla de convênios administrativos colaborativos, também se fala em convênios em sentido próprio, restringindo o alcance da expressão àqueles ajustes assim intitulados pela Administração, sujeitando-os a uma disciplina normativa específica, a exemplo do Decreto Federal $n^{\circ} 6.170 / 2007$, que se refere apenas aos convênios e contratos de repasse.

193 Janaina SCHOENMAKER (2011, p. 61) lembra bem que a celebração de convênio ou contrato de repasse não pressupõe qualquer titulação da organização da sociedade civil sem fins lucrativos, salvo no que diz respeito à restrição quanto ao fim da entidade, que não poderá ser de interesse mútuo ou corporativo, devendo estar vocacionada ao atendimento desinteressado da sociedade.
} 
Decreto Federal n ${ }^{\circ}$ 6.170/2007 (art. $4^{\circ}$ ) e na Portaria Interministerial MP/MF/CGU 507/2011 $\left(\operatorname{art.~} 8^{\circ}\right)^{194}$ que objetiva à seleção da organização que, nos termos do art. $4^{\circ}$ do Decreto, "torna mais eficaz o objeto do ajuste". O Decreto exige que se dê ampla publicidade ao chamamento público, especialmente por meio da divulgação na primeira página do sítio oficial do órgão ou entidade concedente e no Portal de Convênios ${ }^{195}$.

A realização de convênios administrativos colaborativos no âmbito federal está ainda condicionada, nos termos do art. $3^{\circ}$ do Decreto Federal n ${ }^{\circ}$ 6.170/2007 e 16 da Portaria Interministerial MP/MF/CGU no 507/2011, ao credenciamento prévio da organização da sociedade civil sem fins lucrativos no Sistema de Gestão de Convênios e Contratos de Repasse - SINCONV ${ }^{196}$, que depende do preenchimento de uma série de exigências jurídicas, a exemplo da comprovação de que a entidade exerceu nos últimos 03 (três) anos atividades referentes à matéria projeto do convênio ou contrato de repasse que pretenda celebrar com os órgãos e entidades da Administração Pública federal ${ }^{197}$.

\footnotetext{
${ }^{194}$ Somente com o advento do Decreto Federal n ${ }^{\circ} 7.568 / 2011$ foi que a realização do chamamento público se tornou obrigatória, sendo, na redação originária do Decreto Federal 6.170/2007, uma mera faculdade da Administração. Da mesma forma, a Portaria Interministerial no $127 / 2008$ previa a facultatividade da realização de chamamento público para a celebração de convênios administrativos colaborativos [e do concurso de projetos para a assinatura de termos de parceria com as organizações da sociedade civil de interesse público], transformado em procedimento mandatório apenas com a edição da Portaria Interministerial MP/MF/CGU ${ }^{\circ}$ $507 / 2011$.

${ }^{195}$ De acordo com o art. 13 do Decreto Federal no 6.170/2007, “A celebração, a liberação de recursos, o acompanhamento da execução e a prestação de contas de convênios, contratos de repasse e termos de parceria serão registrados no SINCONV, que será aberto ao público, via rede mundial de computadores - Internet, por meio de página específica denominada Portal dos Convênios", acessível através do endereço eletrônico <https://www.convenios.gov.br/portal/>. Neste ponto, João Gabriel Gomes PEREIRA (2011, p. 08) comenta que o chamamento público [e o concurso de projetos dos termos de parceria] deve ser orientado não apenas pelos princípios da isonomia e eficiência (que lhe são inerentes), mas também pelos da transparência e publicidade, revelando-se essencial a ressalva contida no $\S 2^{\circ}$ do art. $4^{\circ}$ do Decreto em comento [e repetida no $\S 2^{\circ}$ do art. 23 do Decreto Federal $n^{\circ} 3.100 / 1999$ ] que obriga a "adoção de formas simples, suficientes para propiciar adequado grau de certeza, segurança e respeito aos direitos dos cidadãos", na medida em que "a práxis revela que nem sempre os processos seletivos realizados nas plataformas digitais do Poder Público na internet deixam claros os procedimentos e fundamentos das decisões que culminam na seleção da entidade ou, até mesmo, na anulação do certame".

196 O Decreto Federal n 6.170/2007 instituiu o Sistema de Gestão de Convênios e Contratos de Repasse (SICONV), cujas regras foram posteriormente detalhadas pela Portaria Interministerial $\mathrm{n}^{\circ} 127$, de 29 de maio de 2008, ambos vindo a ser aperfeiçoados pelos Decretos $\mathrm{n}^{\circ} 6.329 / 2007, \mathrm{n}^{\circ} 6.428 / 2008, \mathrm{n}^{\circ} 6.497 / 2008$ e $^{\circ}$ 6.619/2008 e pelas Portarias $n^{\circ} 165 / 2008$ e $n^{\circ} 342 / 2008$. De acordo com o art. 13 do Decreto Federal $n^{\circ}$ 6.170/2007 e art. $3^{\circ}$ da Portaria Interministerial STM n ${ }^{\circ}$ 507/2011, registram-se nesse sistema a celebração, liberação de recursos, acompanhamento da execução e prestação de contas dos convênios, contratos de repasse e termos de parceria.

${ }^{197}$ Em crítica ao SINCONV, José Eduardo Sabo PAES (2013, p. 811) afirma que, embora se proponha a unificar e facilitar a apresentação de projetos aos programas ofertados pelo Governo Federal, o sistema acabou resultando o aumento do custo financeiro e dos riscos econômicos e políticos envolvidos na relação jurídica de conveniamento com o Estado. Para o Autor, é necessário garantir maior diálogo e participação das organizações da sociedade civil na regulamentação do SINCONV, passando por ações de capacitação, grupos de trabalho e comitês, incorporando-se ao Comitê Gestor do SINCONV ( $\$ \S 1^{\circ}$ e $4^{\circ}$ do art. 13 do Decreto Federal $n^{\circ}$ $6.170 / 2007)$ representantes de entidades privadas sem fins lucrativos.
} 
Por sua vez, embora não exista previsão legal ou infralegal que obrigue expressamente a realização de procedimento objetivo de seleção de OSs para a celebração de contrato de gestão, a sua exigência decorre diretamente do princípio [constitucional] fundamental da igualdade (arts. $3^{\circ}$, IV, e $5^{\circ}$, caput e I, da Constituição) e dos princípios constitucionais administrativos da impessoalidade, eficiência e moralidade (art. 37, caput, da Constituição) ${ }^{198}$. Esse é o entendimento de Maria Sylvia Zanella DI PIETRO (2015, p. 281), segundo a qual a escolha da organização social exige licitação pública, de modo a enquadrar adequadamente a entidade nos princípios constitucionais que regem a gestão do patrimônio público ${ }^{199}$.

Quanto aos termos de parceria com as OSCIPs, hoje eles estão submetidos ao denominado concurso de projetos, o qual, tratado originalmente no Decreto Federal $\mathrm{n}^{\circ}$ 3.100/1997 como uma faculdade da Administração Pública, se tornou compulsório com a edição do Decreto Federal $n^{\circ} 7.568 / 2011$, que modificou a redação do art. 23 daquele diploma infralegal para dele fazer constar o verbo "deverá" ao invés de "poderá"200.

Destaque-se que, com a edição da Portaria Interministerial MP/MF/CGU n ${ }^{\circ}$ 507/2011, homogeneizou-se o tratamento jurídico do chamamento público (para convênios administrativos colaborativos) e do concurso de projetos (para termos de parceria com

\footnotetext{
${ }^{198}$ Neste exato sentido, os Ministros Ayres BRITTO e Luiz FUX, no julgamento do mérito da ADI no 1.923 5, deram interpretação conforme aos arts $5^{\circ}, 6^{\circ}$ e $7^{\circ}$ da Lei Federal no 9.637/1998 "para deles afastar qualquer interpretação excludente da realização de peculiar proceder competitivo público e objetivo para: a) a qualificação de entidade privada como "organização social"; b) a celebração do impropriamente chamado 'contrato de colaboração'. Ousamos discordar dos Ministros, contudo, em relação à qualificação da entidade, pois, salvo no que se refere à declaração de utilidade interesse social e utilidade pública conferida pelo art. 11 da Lei das OSs - da qual, nos termos do art. $3^{\circ}$ da Lei Federal no 91/1935, não decorre nenhum favor do Estado, salvo a garantia de uso exclusivo de emblemas, flâmulas, bandeiras ou distintivos próprios -, a entidade que recebe o título de organização social não recebe automaticamente qualquer recurso público, havendo verdadeira inviabilidade de competição no caso, sendo apenas exigível da Administração que proceda à qualificação nos termos legais, conferindo o preenchimento dos requisitos contidos no art. $2^{\circ}$ da Lei das OSs. Essa qualificação de entidades, inclusive, como observa o próprio Ministro Luix FUX no decorrer do seu voto, não se configura como contratação no sentido próprio do termo, mas como credenciamento. Todo esse nosso raciocínio se aplica perfeitamente à qualificação das OSCIPs (Lei Federal nº.790/1999).

${ }^{199}$ Registre-se que, diante da previsão do Programa Nacional de Publicização (art. 20) - com a possibilidade das OSs incorporarem atividades de órgãos ou entidades públicas extintas -, da participação estatal no conselho de administração das OSs (art. $3^{\circ}$ ) e das robustas prerrogativas asseguradas às OSs - cessão de bens públicos com dispensa de licitação (art. 12) e cessão de servidores públicos com ônus para a origem (art. 14), alguns juristas defendem que as organizações sociais prestam serviços públicos tradicionalmente compreendidos, funcionando o contrato de gestão como um instrumento de delegação estatal, razão pela qual a sua celebração se submete à Lei Geral de Licitações. É o caso de Fernando Borges MÂNICA (2009, p. 259) e Maria Sylvia Zanella DI PIETRO (2015, p. 279-281).

${ }^{200}$ Joé Eduardo Sabo PAES (2013, p. 703) afirma não ter dúvidas de que as OSCIPs deviam ser escolhidas por meio de concurso de projetos (ou outro procedimento objetivo simplificado de seleção) mesmo antes do advento do Decreto Federal $n^{\circ}$ 7.568/2011, anotando inclusive a existência de boas práticas nesse sentido no âmbito da Administração Pública Federal, citando como exemplo a Portaria no 458/2011 do Ministério da Justiça que determinava a realização de concurso de projetos para firmatura de termos de parceria em todo o órgão e entidades vinculadas.
} 
OSCIPs), estabelecendo o seu art. $8^{\circ}$ que "A formação de parceria para execução descentralizada de atividades, por meio de convênio ou termo de parceria, com entidades privadas sem fins lucrativos deverá ser precedida de chamamento público ou concurso de projetos a ser realizado pelo órgão ou entidade concedente, visando à seleção de projetos ou entidades que tornem eficaz o objeto do ajuste".

Essa Portaria fixou etapas comuns para a celebração desses instrumentos de parceria, a saber: (i) credenciamento prévio da entidade da sociedade civil sem fins lucrativos junto ao SICONV (art. 18); (ii) apresentação de proposta de trabalho no SICONV, em conformidade com o programa e com as diretrizes disponíveis no sistema (arts. 19-20); (iii) cadastramento dos proponentes oriundos do Orçamento Fiscal e da Seguridade Social da União no órgão ou entidade concedente ou nas unidades cadastradoras do Sistema de Cadastro Unificado de Fornecedores - SICAF a ele vinculadas, registro esse que terá validade de 01 (um) ano (art. 21-23) 201; (iv) apresentação do plano de trabalho ao órgão ou entidade repassadora de recursos quanto à viabilidade e adequação aos objetivos do programa, devendo conter, no mínimo, justificativa para a celebração do ajuste, descrição completa do objeto, metas, etapas ou fases de execução, cronograma de execução do objeto e de desembolso e plano de aplicação dos recursos a serem desembolsados pelo concedente e de eventual contrapartida do proponente (art. 25); e (v) apresentação do projeto básico ou termo de referência, quando, respectivamente, esteja envolvida a realização de obras ou serviços ou a aquisição de bens ou serviços, admitindo-se a sua entrega após a celebração do instrumento, desde que antes da liberação da primeira parcela dos recursos.

Finalmente, a recente Lei Federal no 13.019/2014 exige a realização do também assim intitulado chamamento público para a celebração do termo de colaboração e do termo de fomento com as organizações da sociedade civil sem fins lucrativos, estabelecendo no inciso XII do seu art. $2^{\circ}$ :

XII - chamamento público: procedimento destinado a selecionar organização da
sociedade civil para firmar parceria por meio de termo de colaboração ou de
fomento, no qual se garanta a observância dos princípios da isonomia, da
legalidade, da impessoalidade, da moralidade, da igualdade, da publicidade, da
probidade administrativa, da vinculação ao instrumento convocatório, do
julgamento objetivo e dos que lhes são correlatos;

${ }^{201}$ Conforme percebe Carolina Caiado LIMA (2010, p. 116-117), o credenciamento após a apresentação da proposta de trabalho configura verdadeira inversão de fases no procedimento prévio de seleção, pois se procede à avaliação da qualificação técnica e capacidade operacional das proponentes antes da análise da sua regularidade jurídica e fiscal (feita no cadastramento). 
$\mathrm{O}$ art. 23 desse novel diploma normativo traz disciplina pormenorizada do tal chamamento público, destacando se tratar de procedimento claro, objetivo, simplificado e, sempre que possível, padronizado ${ }^{202}$, que oriente os interessados e facilite o acesso direto aos órgãos da administração pública, independentemente da modalidade de parceria prevista na Lei. De acordo com Maria Sylvia Zanella DI PIETRO (2015, p. 301-304), conquanto a Lei não indique expressamente as fases do procedimento de chamamento público, pode-se dizer que ele compreende a do instrumento convocatório (edital), a de julgamento e classificação, a de homologação e a de habilitação, sendo que, nos termos do art. 28 da Lei, somente depois de encerrada a etapa competitiva e ordenadas as propostas é que a Administração procederá à verificação dos documentos que comprovem o atendimento pela organização da sociedade civil selecionada dos requisitos de habilitação ${ }^{203}$.

Em todos esses casos de chamamento público e de concurso de projetos, a lei ou decreto correspondente trouxe hipóteses de dispensa, situações em que a realização de procedimento de seleção de entidades de colaboração implicaria potencial prejuízo aos interesses públicos que subjazem aos serviços fomentados ${ }^{204}$. No caso dos termos de colaboração e de fomento previstos na Lei Federal n 13.019/2014, há ainda uma hipótese de inexigibilidade em seu art. 31, por inviabilidade de competição decorrente da natureza singular do objeto do plano de trabalho ou quando as metas somente puderem ser atingidas por uma entidade específica.

202 O par. único desse art. 23 reza que, sempre que possível, a Administração Pública fixará critérios e indicadores padronizados a serem seguidos, especialmente quanto ao objeto, metas, métodos, custos, plano de trabalho e indicadores quantitativos e qualitativos de avaliação de resultados. A exigência de padronização vem a conferir maior segurança jurídica a todo o procedimento, permitindo o efetivo controle da lisura da seleção da entidade parceira do Estado, tanto pelos concorrentes quanto pela sociedade, além de facilitar o trabalho da Administração Pública na escolha da entidade mais apta à realização do interesse público subjacente à cooperação pretendida. Não se trata de uma prática nova na Administração Pública Brasileira, já estando prevista na Portaria Interministerial MP/MF/CGU no 507/2011, segundo a qual a padronização consiste no "estabelecimento de critérios e indicadores a serem seguidos nos convênios com o mesmo objeto, definidos pelo concedente, especialmente quanto às características do objeto e ao seu custo".

${ }^{203}$ Trata-se dos requisitos constantes do art. $24, \S 1^{\circ}$, VII, da Lei (mínimo de três anos de existência, com cadastro ativo, comprovados por meio de documentação emitida pela Secretaria da Receita Federal do Brasil, com base no Cadastro Nacional da Pessoa Jurídica - CNPJ; experiência prévia na realização, com efetividade, do objeto da parceria ou de natureza semelhante; e capacidade técnica e operacional para o desenvolvimento das atividades previstas e o cumprimento das metas estabelecidas), além daqueles previstos nos arts. 33 (exigências do estatuto, basicamente relacionados com a comprovação de que se trata efetivamente de entidade da sociedade civil sem fins lucrativos de fins comunitários, públicos ou de solidariedade social) e 34 (série de documentos comprobatórios da efetiva existência da entidade, com patrimônio próprio e boas condições estruturais e materiais de funcionamento, bem como da sua regularidade, fiscal e previdenciária. Interessante perceber que, como medida moralizadora, o art. 39 da Lei ainda traz a exigência da entidade possuir uma "ficha limpa".

${ }^{204}$ É o que estabelece o $\S 2^{\circ}$ do art. $4^{\text {o }}$ do Decreto Federal $n^{\circ} 6.170 / 2007$, o $\S 2^{\circ}$ do art. 23 do Decreto Federal $\mathrm{n}^{\circ}$ 3.100/1999, o art. $9^{\circ}$ da Portaria Interministerial MP/MF/CGU n ${ }^{\circ}$ 507/2011 e o art. 30 da Lei Federal $n^{\circ}$ $13.019 / 2014$. 
A realidade é que, independentemente de previsão legal e do nomen iuris que se confira ao contrato de colaboração, a realização de procedimento objetivo de seleção é, em regra, imperiosa, jamais podendo a Administração Pública se furtar à observância dos princípios fundamentais da isonomia, impessoalidade, moralidade, eficiência e publicidade, direcionando a sua ação de fomento a determinadas entidades.

Da mesma forma que ocorre com as licitações públicas, o procedimento de seleção das entidades de colaboração deve ocorrer em pelo menos duas fases: (i) interna ou preparatória, na qual a Administração Pública deve por em prática a sua atividade de planejamento $^{205}$, através do diagnóstico da realidade que pretende alterar, da definição do objeto, metas, métodos e custos do fomento que quer desenvolver e da elaboração do edital de seleção, com a especificação da programação orçamentária que autoriza e fundamenta a celebração do instrumento colaborativo, do tipo de parceria, dos cronogramas de execução, das condições, local e forma de apresentação das propostas e, finalmente, dos critérios objetivos de seleção e julgamento, buscando-se sempre uma padronização dos certames; e (ii) externa, que se inicia com a abertura das inscrições e recebimento das propostas e culmina com a contratação da entidade mais apta à realização do objeto da parceria oferecida, tudo em conformidade com os termos do edital de seleção e a legislação de regência.

Registre-se também que, qualquer que seja a espécie de contrato de colaboração a celebrar, o edital do procedimento de seleção poderá conter, a par dos requisitos/condições já previstos nas leis e atos administrativos de regência, outras exigências dos concorrentes, não se admitindo, contudo, conforme leciona Maria Sylvia Zanella DI PIETRO (2015, p. 302), discriminações impertinentes ou irrelevantes para o específico objeto da parceria, sob pena de violação do princípio da razoabilidade, que exige relação ou adequação de meios e fins.

\footnotetext{
${ }^{205}$ Cumpre sobrelevar a importância do planejamento estatal no fomento do setor social, etapa muitas vezes negligenciada pela Administração Pública, que não se debruça atentamente sobre a realidade da área em que pretende intervir, não avaliando satisfatoriamente as deficiências do sistema, não elegendo de forma embasada e estratégica os setores considerados prioritários, vindo a construir, por conseguinte, um projeto de ação administrativa débil, com perda significativa de eficiência alocativa - de acordo com Floriano de Azevedo MARQUES NETO (2010, p. 211),“A ideia de eficiência alocativa, cara à Economia, diferencia-se de uma eficiência considerada estática na medida em que, partindo do pressuposto de que os recursos podem estar nas mãos de quem faz melhor ou pior uso, busca uma alocação dos recursos de maneira eficiente, de forma que seja dada a eles a melhor destinação possível[...]" -, a comprometer o atendimento das necessidades sociais que se quer atender. A fase de seleção de entidades parceiras do Estado, portanto, situa-se muito mais no âmbito do planejamento estatal do que naquele do fomento propriamente dito.
} 
Exigência que se mostra fundamental à realização do interesse público e proteção dos direitos fundamentais dos cidadãos, outrossim, é a de tempo mínimo de existência e de experiência da entidade privada na área em que o Estado pretende fomentar. Embora não se deva exagerar neste requisito sob pena de restringir sobremaneira o caráter competitivo da seleção, inviabilizando o acesso de novas organizações, com prejuízos à inovação e mesmo ao direito fundamental de participação nos negócios públicos, cuida-se de medida que visa a orientar os processos de celebração de parceria para aquelas entidades que tenham efetiva atuação na área, com lastro técnico e comunitário. Afastam-se, como bem colocado pela Plataforma por um Novo Marco Regulatório para as Organizações da Sociedade Civil (2014), organizações inidôneas, criadas de véspera para receber recursos públicos ou sem condições de demonstrar a efetiva capacidade técnica e operacional de realizar o objetivo social perseguido, protegendo-se o interesse público ${ }^{206}$.

Requisito controverso, contudo, é a cobrança de contrapartida da entidade de colaboração, a ser entendida, conforme leciona Guilherme Henrique La Rocque ALMEIDA (2008, p. 150), como a parcela de gastos a ser arcada pela entidade proponente, estabelecida de acordo com sua capacidade financeira, através de recursos financeiros ou bens e serviços economicamente mensuráveis.

Para Paulo Eduardo Garrido MODESTO (2006, p. 10), é insuficiente considerar como contrapartida o simples desempenho da atividade de relevância pública pela entidade privada parceira do Estado, dela devendo-se exigir pelo menos a existência de patrimônio ou qualificação técnica especial para a própria candidatura, bem como, se for o caso, contraprestação em termos de certo percentual de serviços gratuitos em favor dos cidadãos.

Assim também entendeu o TCU no Acórdão no 235/2003, quando recomendou que, na verificação da capacidade técnico-operacional das entidades proponentes [de convênios e contratos de repasse], seja avaliada a real capacidade instalada da entidade proponente,

\footnotetext{
${ }^{206}$ Assim dispõe o art. $8^{\circ}, \S 1^{\circ}$, IV, da Portaria Interministerial MP/MF/CGU n ${ }^{\circ}$ 507/2011, requerendo das organizações não estatais sem fins lucrativos comprovante do exercício, nos últimos 03 (três) anos, de atividades referentes à matéria objeto do convênio ou termo de parceria que pretenda celebrar com órgão ou entidade $^{206}$. Na verdade, trata-se de requisito do próprio cadastramento prévio da entidade sem fins lucrativos no SINCONV (art. $3^{\circ}, \S 2^{\circ}$, VI, do Decreto Federal n ${ }^{\circ} 6.170 / 2007$ ), exigido tanto para a celebração de convênios e contratos de repasse quanto de termos de parceria com OSCIPs. A novel Lei Federal n ${ }^{\circ} 13.019 / 2014$ segue o mesmo caminho, requerendo o mínimo de 03 (três) anos de existência da entidade e experiência prévia na área objeto da parceria ou de natureza semelhante (art. 24, $\S 1^{\circ}$, VII, I e II), requisito esses ainda mais rigorosos quanto se tratar de "atuação em rede" (execução de iniciativas agregadoras de pequenos projetos por duas ou mais organizações da sociedade civil).
} 
entendida como os recursos humanos devidamente qualificados, instalações, recursos materiais e financeiros necessários à fiel execução do objeto conveniado.

Nessa mesma toada, Carolina Caiado LIMA (2010, p. 117) entende ser imprescindível avaliar se a entidade proponente possui recursos próprios (inclusive financeiros) para desenvolver as suas atividades, porquanto o fomento público é [seria] atividade transitória, visando a estimular o exercício de projetos de interesse público e coletivo por entidades privadas sem fins lucrativos, e não prover o custeio operacional dessas entidades, sendo essencial o caráter transitório do fomento para se evitar protecionismos [injustificados $]^{207}$.

Comentando a suposta facultatividade da contrapartida nos convênios e contratos de repasse, Ubiratan AGUIAR, Ana Claudia Messias de Lima MARTINS, Paulo Roberto WIECHERS e Pedro Tadeu Oliveira da SILVA (2008, p. 39) consideram-na mandatória, na medida em que o ônus da execução do instrumento de parceria deve também ser suportado pela entidade beneficiária dos recursos públicos repassados.

No entanto, mais preocupada com o amplo acesso das organizações da sociedade civil aos instrumentos de parceria estatal, a Plataforma por um Novo Marco Regulatório para as Organizações da Sociedade Civil (2014, p. 08) defende que a contrapartida natural que as entidades de colaboração têm a oferecer ao Estado é exatamente a sua capacidade e acervo técnico, não sendo admitida a cobrança de contrapartidas financeiras, com vistas a favorecer a participação de organizações com menor disponibilidade financeira. Foi esse o principal argumento que levou a Lei Federal $\mathrm{n}^{\mathrm{o}}$ 13.019/2014 a proscrever expressamente a possibilidade de exigência de contrapartida financeira como requisito para a celebração de parceria, facultada a exigência de contrapartida em bens e serviços economicamente mensuráveis (arts. 35, § $1^{\circ}$, e $\left.42, \mathrm{~V}\right)^{208}$.

\footnotetext{
${ }^{207}$ Exigir patrimônio próprio e disponibilidade financeira das entidades de colaboração é deveras fundamental para evitar a contratação de instituições $a d$ hoc, de fachada, sem maior consistência, especialmente criadas para receber recursos públicos, garantindo-se, assim, a boa execução do objeto da parceria e o alcance dos objetivos públicos perseguidos, protegendo-se, ainda, a credibilidade dos instrumentos de parceria (Paulo Eduardo Garrido MODESTO, 2006, p. 10). No entanto, segundo pensamos, tais requisitos não decorrem da suposta transitoriedade do fomento público, senão dos princípios constitucionais da eficiência e moralidade, sendo indispensáveis à realização do interesse público. A discutível transitoriedade do fomento público já foi abordada neste trabalho.

${ }^{208}$ Assinale-se que, embora a Portaria Interministerial MP/MF/CGU n ${ }^{\circ}$ 507/2011 preveja a possibilidade de cobrança de contrapartida do colaborador privado nos convênios e termos de parceria sem fazer qualquer ressalva, a superveniência da Lei Federal $\mathrm{n}^{\mathrm{o}}$ 13.019/2014 acabou vedando a exigência de contrapartida financeira para os termos de parceria com as OSCIPs, na medida em que as suas disposições se aplicam a esta espécie de colaboração naquilo que couber, retirando o fundamento de validade dessa previsão contida no ato infralegal interministerial.
} 
Para nós, a contrapartida do parceiro privado - ainda que não necessariamente financeira, admitindo-se a demonstração da capacidade técnico-operacional da entidade pela comprovação do seu patrimônio físico e humano e expertise na área fomentada - é obrigatória e vem ao encontro dos princípios da eficiência e moralidade administrativas, garantindo-se o objetivo maior da realização do interesse público, na medida em que afasta entidades inidôneas, simplesmente criadas para o recebimento de recursos públicos e incapazes de concretizar os objetivos sociais traçados. É na verdade, um imperativo do referido princípio da repartição dos riscos ou do risco compartilhado, que, de acordo com Rita TOURINHO (2010, p. 326), leva à obrigação do beneficiário de aportar recursos próprios para a atividade fomentada, com fulcro no art. 16 da Lei Federal n 4.320/64.

Carolina Caiado LIMA (2010, p. 106-107) observa a impossibilidade de sujeitar os convênios administrativos colaborativos/convênios lato sensu [contratos de colaboração] à prévia autorização do Poder Legislativo, referindo a posição do STF pela inconstitucionalidade de tais previsões em constituições estaduais e leis orgânicas municipais, consignando-se que a decisão de celebrar convênios [e outros instrumentos colaborativos] constitui ato de gestão do Executivo, despida de interferências do Legislativo. De acordo com a Autora, além de inconstitucional, a exigência afigura-se desnecessária, mercê da necessidade de autorização na própria lei orçamentária anual.

No que diz respeito ao critério de julgamento, cumpre reconhecer a total inadequação do critério do menor preço ou taxa de administração ao regime de acertamento mútuo dos contratos de colaboração, no qual, como bem adverte Marcela Roza Leonardo ZEN (2008, p. 90-91), a seleção da entidade parceira deve se orientar pelo melhor projeto apresentado, com vistas nos resultados sociais pretendidos. Neste ponto, inclusive, o art. 27 da Lei Federal no 13.019/2014 impõe como critério obrigatório - dentre outros que venham a ser utilizados pela Administração Pública - "o grau de adequação da proposta aos objetivos específicos do programa ou ação em que se insere o tipo de parceria e ao valor de referência constante do chamamento público".

Por fim, destaque-se ser indispensável a instrumentalização da participação social no processo de seleção de entidades de colaboração, especialmente no planejamento estatal que antecede a atividade de fomento em si, tratando-se dum imperativo da cidadania e da Administração Pública Consensual a garantia de seu acesso à sociedade, que não apenas deve estar ciente de tudo que a Estado planeja executar, mas especialmente deve poder interferir na sua decisão. É exatamente essa a ratio do Procedimento de Manifestação de 
Interesse Social previsto na Lei Federal no 13.019/2014, o qual, de acordo com o art. 18 da Lei, é o "instrumento por meio do qual as organizações da sociedade civil, movimentos sociais e cidadãos poderão apresentar propostas ao poder público para que este avalie a possibilidade de realização de um chamamento público objetivando a celebração de parceria"209. Impulsionando a participação social nos assuntos de interesse coletivo, esta novel legislação ainda trouxe a figura do termo de fomento, vínculo formal de parceria em que são as próprias entidades sem fins lucrativos que propõem finalidades de interesse público a serem perseguidas.

${ }^{209}$ A Lei Federal n ${ }^{\circ}$ 9.790/1999 também estabelece que a celebração de termo de parceria com as OSCIPs será precedida de consulta aos Conselhos de Políticas Públicas, instrumentos de participação popular, controle social e gestão democrática das políticas e dos serviços públicos, envolvendo o seu planejamento e acompanhamento da execução, com representantes do Poder Público e da sociedade. 


\section{DO REGIME DE PRESTAÇÃO DOS SERVIÇOS SOCIAIS}

Verificado que os serviços sociais se enquadram na categoria dos serviços de relevância pública, temos que a sua prestação não estatal se submete ao regime jurídico de Direito Privado, pautado pela livre iniciativa e ausência de prerrogativas extroversas, porém derrogado por normas publicísticas, especialmente relacionadas com a pertinência coletiva da atividade empreendida ${ }^{210}$.

Esse estatuto jurídico híbrido envolve a composição e compatibilização da autonomia/liberdade privada das entidades de colaboração com a realização dos interesses coletivos e proteção da dignidade da pessoa humana: por um lado, a affectio socialis do objeto dessas parcerias justifica a imposição de compromissos públicos aos parceiros privados, fixados necessariamente através da atividade legiferante do Estado, ou por meio de cláusulas apostas no próprio instrumento colaborativo enquanto condição para o emparceiramento com o Poder Público e recebimento do fomento administrativo; por outro, não se admite o esvaziamento da natureza não estatal de direito privado das entidades de colaboração, que não podem ser submetidas ao regime próprio dos órgãos e entidades da Administração, nem transformadas em garantidores da oferta de utilidades sociais à coletividade, dever este exclusivamente do Estado, instrumento que é de promoção e proteção dos interesses públicos.

Essa exigência de lei formal para a fixação de obrigações publicísticas à iniciativa privada decorre dos já comentados princípios [constitucionais] fundamentais do Estado de Direto (arts. $1^{\circ}$, caput, e $5^{\circ}$, II), da livre iniciativa (arts. $1^{\circ}$, IV , $3^{\circ}$, I, $5^{\circ}$, caput e XIII, e 170 , caput) e da participação democrática (art. $1^{\circ}$, caput e par. único), na medida em que interferem, sempre de forma ponderada, na esfera de liberdade dos particulares, sem prejuízo, contudo, da ação regulatória da Administração Pública, geralmente por meio de agências criadas por lei especialmente para o desempenho dessa função administrativa ${ }^{211}$.

\footnotetext{
${ }^{210}$ Nesse sentido, Gustavo Justino de OLIVEIRA (2007c, p. 229-230) anota que, embora o regime jurídico de Direito Privado seja regra geral para as entidades do terceiro setor, a sua vocação para o desenvolvimento de atividades de interesse público - como saúde, educação e assistência social - faz com que o ordenamento jurídico brasileiro lhes sujeite a disciplinas normativas especiais, aplicáveis a determinados seguimentos de atividades.

${ }^{211}$ A atividade reguladora envolve o exercício de competência normativa abstrata. Isso não significa, contudo, que os órgãos e entidades reguladores possam editar leis em sentido estrito, criando direitos e deveres, inovando o ordenamento jurídico, justamente porque a função regulatória possui natureza administrativa, devendo, pois, estar referenciada em lei formal que lhe confira fundamento de validade. Nessa medida, as matérias que podem ser objeto da ação [administrativa] normativa regulatória restringem-se àquelas previstas em lei - geralmente
} 
Eis a premissa da extensão de deveres públicos à prestação não estatal de serviços sociais: dependência da normatização setorial do serviço, por lei e atos infralegais regulatórios, que jamais poderão esvaziar os princípios constitucionais da livre iniciativa e da participação democrática, não se admitindo a imposição de deveres de obrigatoriedade/garantia aos prestadores $\operatorname{privados}^{212}$.

Trata-se de raciocínio aplicável mesmo aos serviços públicos, cujo imperativo de adequação e seus consectários principiológicos ${ }^{213}$ possuem os seus contornos, ao menos em nosso ordenamento jurídico, necessariamente definidos em lei formal, que não apenas eleva determinada atividade ao patamar de serviço público, instaurando a reserva de exclusividade estatal (publicatio), mas também delineia todo seu o estatuto jurídico (regime jurídico setorial), permeado de compromissos públicos. Não é por acaso que a Constituição Federal,

a que criou a agência reguladora -, ainda que se admita o exercício de competências regulamentares sem previsão legal explícita, bastando que ocorra o chamado processo de derivação, verificando-se a compatibilidade da norma regulamentar com o conteúdo, espírito e finalidade da lei (Marçal JUSTEN FILHO, 2002, p. 517). Sobre o assunto, Dinorá Adelaide Musetti GROTTI (2003, p. 127) destaca as enérgicas oposições doutrinárias à imposição de administrativa de obrigações de serviço público (deveres de adequação) aos serviços sociais, que importaria o perigo de se abandonar as prerrogativas do Poder Legislativo à Administração, facilitando a criação de serviços públicos (publicatio), em prejuízo ao direito dos administrados.

212 É esse o magistério de Gustavo Justino de OLIVEIRA (2007c, p. 230), segundo o qual qualquer condicionamento ou restrição às entidades do terceiro setor decorrente da atividade de interesse público que desenvolvem ou por receberem recursos públicos no contexto da função administrativa de fomento somente é possível "desde que isso esteja expressamente previsto em lei". Por sua vez, Alexandre Santos ARAGÃO (2008, p. 197-) sustenta que "[...] as atividades privadas de interesse público integram a esfera privada da ordem econômica constitucional", sendo a livre iniciativa privada o principal direito fundamental dos particulares decorrente dessa posição institucional oponível à regulação estatal. Para o Autor, a imposição de limites e condições a essas "atividades privadas de interesse público" pressupõe a ponderação (proporcionalidade) entre a livre iniciativa privada e os valores de interesse público que estiverem em jogo, nunca se admitindo que as restrições coarctem o núcleo essencial do direito à liberdade, para torna-los despiciendos ou pouco significativos. O Autor se reporta à doutrina germânica dos limites dos limites, de acordo com a qual "[...] as limitações aos direitos fundamentais, para serem legítimas, devem atender a um conjunto de condições materiais e formais estabelecidas na Constituição, que são os limites dos limites dos direitos fundamentais" [grifo no original]. Para o Autor, embora o Estado possa fazer com que os particulares contribuam para o atendimento do interesse público setorialmente definido, a fixação de obrigações positivas não pode implicar, pela sua onerosidade excessiva, verdadeira substituição do Estado pela iniciativa privada no cumprimento de suas funções constitucionais, sob pena de se impor uma "[...] programação estatal obrigatória à iniciativa privada, através do estabelecimento de conformação, metas e objetivos (quanto, como e quando produzir), do empreendimento privado, violando o art. 174 da Constituição Federal, para o qual o planejamento é meramente indicativo para a iniciativa privada". Nada obstante, como visto, alinhamo-nos com aqueles que defendem inexistir qualquer óbice à priorização da prestação privada dos serviços sociais, inclusive resultando, salvo nos casos expressamente previstos na Constituição, a substituição da intervenção direta estatal pela indireta. Isso não quer dizer, contudo, que seja legítimo ao Poder Público se retirar da prestação direta de utilidades sociais e forçar a assunção da garantia constitucional de sua prestação adequada pela iniciativa privada. Se a prestação não estatal se mostra desinteressada, insuficiente ou ineficiente, cabe ao Poder Público, este, sim, que tem dever de obrigatoriedade, intervir diretamente no setor social.

213 Diogo de Figueiredo MOREIRA NETO (2014, p. 471) elenca oito princípios jurídicos informativos dos serviços públicos, os quais, em conjunto, atenderiam ao conceito jurídico indeterminado constitucional de serviço adequado (art. 175, par. único, IV), tal como constante da Lei Federal no 8.987/1995 (art. $6^{\circ}$, $\S 1^{\circ}$ ) e da legislação consumerista (art. $6^{\circ}, \mathrm{X}$, da Lei Federal $\mathrm{n}^{\circ}$ 8.078/1990), a saber: generalidade, continuidade, regularidade, eficiência, atualidade, segurança, cortesia e modicidade. 
no par. único do seu art. 175, prevê que a lei disporá sobre a obrigação de manter o serviço adequado, com a fixação dos direitos dos usuários, dever de prestação adequada ${ }^{214}$ esse cuja $^{2}$ noção legal é oferecida pelo art. $6^{\circ}$ da Lei Federal nº 8.987/1995, onde restam consagrados os princípios da regularidade, continuidade, eficiência, segurança, atualidade, generalidade, cortesia e modicidade.

Sem embargo, não há como negar que, diante da ligação imanente das atividades sociais com a dignidade da pessoa humana (art. 1º, III, da Carta Política Brasileira), associada à aplicabilidade imediata dos princípios e garantias fundamentais $\left(\operatorname{art} .5^{\circ}, \S 1^{\circ}\right.$, do nosso Texto Constitucional), algumas limitações à execução de serviços sociais pela iniciativa privada sem fins lucrativos - e mesmo por aquela voltada ao mercado, veja bem decorrem diretamente da Constituição, independentemente de ato inferior que restrinja a liberdade dos agentes não estatais. É o caso, por exemplo, da obrigação de não discriminar usuários, cuja base normativa é o direito fundamental da igualdade (arts. $3^{\circ}$, IV, e $5^{\circ}$, caput), que reclama tratamento isonômico mesmo nas relações privadas ${ }^{215}$.

São essas as já mencionadas lições de Paulo Eduardo Garrido MODESTO (2011, p. 12-13), para quem os serviços de relevância pública estão submetidos a uma físcalização e regulação minudente do Poder Público, como forma de garantir os princípios constitucionais, especialmente o da dignidade da pessoa humana, na medida em que "[...] poderes, prerrogativas públicas e sujeições não se presumem, sem norma de atribuição, especialmente para entidades privadas não estatais".

Nesse mesmo trilhar, Carlos Ari SUNFELD e Rodrigo Pagani de SOUZA (2011, p.76) asseveram que qualquer equiparação entre o universo estatal e o não estatal pressupõe previsão legal expressa, tratando-se de exceção que deve ser lida com cautela, especialmente porque “[...] aplicar às entidades do Terceiro Setor o regime a que se submete o Estado, pura e simplesmente, é anular a flexibilidade de gestão que essas entidades têm a oferecer e, com ela, os bons resultados que podem alcançar".

Essa necessidade de normatização estatal para a imposição de deveres públicos à prestação privada dos serviços sociais é reconhecida mesmo entre aqueles doutrinadores que

\footnotetext{
${ }^{214} \mathrm{O}$ inciso X do art. $6^{\circ}$ do Código de Defesa do Consumidor (Lei Federal no 8.078/1990) também consagra o direito dos consumidores à prestação adequada e eficiente dos serviços públicos.

${ }^{215}$ Lembre-se que a eficácia horizontal dos direitos e garantias fundamentais é amplamente reconhecida pela nossa doutrina e jurisprudência pátrias, especialmente para vedar condutas discriminatórias, violadoras da igualdade constitucional e, no limite, da dignidade da pessoa humana. Nesse sentido: STF, RE $\mathrm{n}^{\circ}$ 161.2436/DF.
} 
não enquadram essas atividades na categoria jurídica própria dos serviços de relevância pública, tratando-os como uma atividade privada - aberta à livre iniciativa, sem privilégio ou monopólio estatal - simplesmente sujeita à disciplina especial do Poder Público, que regula a ação da iniciativa privada no setor social com maior intensidade em virtude da sua serviência ao interesse geral, jamais olvidando, por outro lado, do respeito ao princípio constitucional da livre iniciativa . Assim, Dinorá Adelaide Musetti GROTTI (2003, p. 127), in litteris:

Trata-se de atividades privadas submetidas a intensas manifestações do poder de polícia, tendo em conta que são exercidas pelos particulares, no uso de sua "competência privada originária", sujeitas a um regime jurídico de Direito privado, caracterizado pela liberdade de exercício e contratação, cujas normas regulamentares devem observar os limites das garantias constitucionais para o desempenho de uma atividade livre ${ }^{216}$.

Avançando mais um pouco, perfilhando, aqui, o entendimento de que os serviços sociais caracterizam serviços de relevância pública, cumpre-nos reconhecer-lhe a existência dum regime jurídico próprio ${ }^{217}$ cujos compromissos públicos impostos à sua prestação pelos particulares não decorrem apenas da atividade de polícia estatal, como se não existisse diferença em relação à regulamentação oficial do exercício das atividades econômicas em sentido estrito ${ }^{218}$.

É verdade que o elemento sócio-ideológico das normas constitucionais (José Afonso da Silva, 2009, p.) reclama, in casu, a compatibilização da livre iniciativa com os compromissos de justiça social e existência digna (art. 170, caput) em toda e qualquer atividade empreendida pelos particulares, exigindo a tutela de polícia do Estado nessa composição de interesses legítimos. Todavia, não é menos verdade que o substrato material dos serviços de relevância pública carrega consigo sujeições publicísticas muito mais

\footnotetext{
${ }^{216}$ Na doutrina estrangeira, Juan Carlos CASSAGNE (1992, p. 39, 43-44) sustenta que o regime dos serviços sociais se aproximaria daquele dos serviços públicos em alguns pontos, dependentes exatamente da ação regulamentar do Estado: dum lado, a natureza originariamente privada dos serviços sociais asseguraria aos particulares direito subjetivo pleno de exercê-las, valendo, aqui, o princípio da liberdade, cujo conteúdo afasta os deveres de obrigatoriedade e de igualdade ${ }^{216}$; e, doutro, esse dever subjetivo não seria absoluto, sujeitandose à regulamentação estatal da atividade, sempre tendo em conta que regulamentar um direito não é suprimi-lo ou limitá-lo desarrazoadamente, mas fazê-lo compatível com o direito dos demais e, neste caso, com o interesse geral ou público.

${ }^{217}$ Lembre-se que, consoante as já mencionadas lições de Flávio GALDINO (2005, p. 123), as categorias jurídicas são ativadores de regimes jurídicos, de modo que a classificação dos serviços sociais como serviços de relevância pública deve implicar um estatuto jurídico próprio, inerente à atividade.

${ }^{218}$ Dinorá Adelaide Musetti GROTTI (2003, p. 125), por exemplo, defende não haver diferença substancial entre a atividade de polícia empreendida pelo Poder Público em relação às atividades privadas em geral (atividade econômica em sentido estrito) e a regulamentação do exercício dos serviços sociais.
} 
intensas do que o controle de polícia administrativa, identificando-se verdadeira unidade de sentido entre os serviços sociais e os serviços públicos, num avizinhamento de regime jurídico determinado pelo caráter público [em sentido material, objetivo] desses núcleos de atividade (Alexandre Santos de ARAGÃO, 2008, p. 156-157).

Em linhas gerais, a natureza de relevância pública dos serviços sociais impõe:

- a aplicação direta de normas constitucionais aos serviços sociais, a exemplo da submissão da sua prestação à fiscalização pelo Ministério Público (art. 129, II) (Paulo Eduardo Garrido MODESTO, 2011, p. 12) e da possibilidade de impugnação dos atos praticados pelos prestadores particulares pela via do mandado de segurança (art. $5^{\circ}$, LXIX);

- mais do que um controle de polícia geral - que apenas verifica se a atividade não fere a ordem, saúde ou segurança pública, mesmo que admitida a fixação de obrigações positivas -, justificando uma intervenção estatal particularmente intensa que funcionalize específica e comissivamente essas atividades ao interesse público, com maiores limitações à liberdade privada (Alexandre Santos de ARAGÂO, 2008, p. $195)^{219}$;

- e verdadeiro dever de garantia estatal da sua adequação, voltado à universalização, continuidade e eficiência das prestações sociais.

Para delinear o regime jurídico da prestação dos serviços sociais no âmbito dos contratos de colaboração, faz-se necessário, então, divisar 03 (três) situações distintas: (i) prestação estatal de serviços sociais; (ii) prestação não estatal de serviços sociais sem qualquer auxílio público oficial; e (iii) prestação não estatal de serviços sociais em parceria com o Poder Público, através de contratos de colaboração:

No primeiro caso, temos os serviços sociais prestados pelo Estado: (a) enquanto atividade estatal, o seu regime jurídico será, de acordo com Paulo Eduardo Garrido

\footnotetext{
${ }^{219}$ Pode-se dizer que o substrato material dos serviços de relevância pública - assim como ocorre com os serviços públicos - promove uma redução do mencionado limite dos limites, permitindo uma maior incursão restritiva sobre a livre iniciativa privada comparativamente às atividades econômicas em sentido estrito. Registre-se que o STF reconheceu, no julgamento da ADI no 319-4-DF, possibilidade de controle sobre o aumento do valor das mensalidades das escolas privadas trazido pela Lei Federal ${ }^{\circ}$ 8.039/1990, afirmando que, a despeito de se tratar de atividade privada (não estatal, aberta à livre iniciativa), a sua vinculação aos interesses públicos reclama uma ingerência estatal diferenciada. Ademais, como bem destaca Dinorá Adelaide Musetti GROTTI (2003, p. 140-41), verifica-se alta regulação estatal nos serviços de saúde prestados pela iniciativa privada.
} 
MODESTO (2005, p. 22), aquele administrativo, próprio dos órgãos ou entidades integrantes da Administração Pública, fundado nos princípios da supremacia e indisponibilidade do interesse público, especialmente os insculpidos no caput do art. 37 da nossa Lei Maior, com destaque para a impessoalidade e a eficiência; (b) em razão da vinculação essencial dos serviços sociais ao interesse público e da natureza instrumental do Estado de atendimento das necessidades coletivas, haverá verdadeiro dever de garantia estatal da prestação adequada dessas utilidades sociais, sob a égide dos seus princípios básicos ${ }^{220}$ garantidores, quais sejam da obrigatoriedade 221 , igualdade ${ }^{222}$ e eficiência.

Em segundo, vêm os serviços sociais executados pela iniciativa privada independentemente de qualquer auxílio estatal: o seu regime jurídico de prestação será essencialmente privado, marcado pela livre iniciativa, não havendo qualquer dever constitucional que faça obrigatória essa prestação não estatal. Com efeito, embora a sociedade civil possua direito subjetivo de participação nos negócios públicos, podendo empreender atividades de relevância coletiva, inexiste qualquer obrigação constitucional/legal de assim proceder (art. $5^{\circ}$, II, da Constituição), cabendo ao Estadoinstrumento, enquanto verdadeiro garantidor das necessidades coletivas, assumir, sempre que a iniciativa privada se mostrar desinteressada, insuficiente ou ineficiente, a prestação direta de tais atividades ou intensificar sua ação administrativa de fomento.

Sem embargo, incursionando os particulares espontaneamente na prestação de serviços sociais, eles estarão submetidos a normas publicísticas: sujeitar-se-ão às diretrizes constitucionais, devendo a sua oferta, por exemplo, em nome do princípio fundamental da isonomia/igualdade, não discriminar os usuários, bem como, com fundamento na dignidade da pessoa humana, não ser interrompida de forma abrupta, devendo a prestadora assegurar a continuidade do serviço aos seus beneficiários junto a outras instituições privadas ou através

\footnotetext{
${ }^{220}$ Falamos básicos porque todos as demais garantias da prestação adequada dos serviços sociais nada mais são do que desdobramentos desses três princípios estruturantes: a continuidade é princípio intimamente ligado ao da obrigatoriedade e da eficiência, impedindo a interrupção injustificada do serviço, sob pena de frustrar as legítimas expectativas e infirmar a dignidade da pessoa humana; a generalidade corresponde em certa medida ao da igualdade, apenas dando destaque para o dever de expansão na prestação estatal dos serviços sociais, que devem ser disponibilizados ao maior número de pessoas, ainda que se admita a legítima eleição [temporária] de grupos prioritários, justificada em razão de limitações reais de recursos públicos; valendo o mesmo, por exemplo, para a mutabilidade ou adaptação, modicidade e cortesia.

${ }^{221}$ Carlos Ari SUNDFELD (1992, p. 83) defende que que os serviços sociais são um dever inafastável do Estado, tendo os indivíduos, inclusive, direito subjetivo de usufrui-los, sendo perfeitamente sindicável.

${ }^{222}$ Trata-se de verdadeiro mandamento constitucional também aplicável às relações privadas, não mais se sustentando o entendimento de Juan Carlos CASSAGNE (1998, p. 43) de que o princípio da liberdade afastaria o imperativo da igualdade da prestação privada de serviços sociais, admitindo a sua execução em [ilegítimas] condições discriminatórias.
} 
do Estado, sempre dentro da razoabilidade e do respeito ao direito dos particulares de cessar as suas atividades (livre iniciativa) ${ }^{223}$; e submeter-se-ão aos compromissos públicos fixados pelo Estado em regulamentação da atividade, cuja imposição, como visto, não se fundamenta simplesmente no poder de polícia, mas no dever de garantia estatal da prestação adequada dessas utilidades, decorrente do seu caráter essencial à coletividade.

Importa observar que esse dever de garantia estatal subsiste mesmo quando a execução dos serviços sociais é feita pelos particulares, cabendo ao Poder Público lançar mão dos instrumentos de intervenção indireta (normatização, fiscalização e fomento) e/ou assumir, quando a iniciativa privada se mostrar desinteressada/incapaz de atender às demandas sociais, a prestação [direta] do serviço, inclusive respondendo pela continuidade da execução da atividade quando interrompida pelos agentes privados ${ }^{224}$.

Finalmente, temos os serviços sociais desenvolvidos pela iniciativa privada em parceria com o Estado, aos quais se aplicam todas as colocações feitas em relação à sua execução não estatal autônoma, apenas com a ressalva de que a sua prestação se submeterá a maiores obrigações públicas, consubstanciadas em metas e objetivos definidos pelo Poder Público como verdadeira contraprestação aos incentivos estatais concedidos. Com efeito, a celebração de contratos de colaboração pela iniciativa privada intensifica os compromissos coletivos impostos à prestação não estatal de serviços sociais, seja por expressa previsão normativa, seja como uma obrigação contratual estipulada de comum acordo.

Assim sendo, essas legislações de parcerias reforçam a incidência genérica de princípios publicísticos nos serviços sociais ${ }^{225}$, a serem combinados com as obrigações consensualmente definidas no instrumento colaborativo, estabelecidas para determinado

\footnotetext{
${ }^{223}$ Aquilo que a dignidade da pessoa humana exige é a impossibilidade da entidade privada interromper bruscamente as suas atividades e deixar os usuários dos seus serviços completamente desamparados. Não se trata, pois, de obrigação de continuidade dos serviços, sendo direito das organizações privadas inerente à livre iniciativa e liberdade de associação a decisão pela interrupção do seu funcionamento. Mais uma vez, somente se pode falar em dever de garantia da prestação adequada de serviços sociais ao Estado, na medida em que é ele quem possui o papel instrumental de garantidor do interesse público. Na esteira do defendido neste trabalho, os contornos dessa vedação à interrupção-surpresa devem ser definidos na legislação que disciplina setorialmente cada serviço social.

${ }^{224}$ Não é à toa a recente Lei de Parcerias Sociais traz expressamente o dever estatal de garantir a continuidade dos serviços sociais prestados através dos termos de colaboração e de fomento, assumindo ou transferindo a execução do objeto da parceria a terceiro em caso de paralisação ou ocorrência de fato relevante (arts. 42, XXII, e 61, II).

${ }^{225}$ Verbi gratia: art. $7^{\circ}$ da Lei Federal no $9.637 / 1998$, art. $4^{\circ}$ da Lei Federal no $9.790 / 1999$ e arts. $5^{\circ}$ e $6^{\circ}$ da Lei Federal $n^{\circ} 13.019 / 2014$.
} 
setor social, à vista das carências de específica localidade/região e voltadas ao atendimento de metas e objetivos traçados democraticamente na função de planejamento estatal ${ }^{226}$.

De mais a mais, imediatamente relacionado com o regime de prestação dos serviços sociais através de contratos de colaboração está o regime dos bens geridos pelo parceiro privado, podendo ser identificado três núcleos distintos:

Em primeiro lugar, temos os bens da entidade de colaboração não afetados diretamente à prestação dos serviços sociais, os quais se inserem no conceito [por exclusão] de bem privado do art. 98 do Código Civil e, como tal, de acordo com os ensinamentos de Maria Sylvia Zanella DI PIETRO (2015, p. 94), “[...] estão no comércio jurídico de direito privado, podendo ser objeto de qualquer relação jurídica regida pelo direito civil ou comercia, como alienação, locação, usucapião, usucapião, direitos reais, inclusive os de garantia (penhor, anticrese e hipoteca)"227.

Em segundo, identificamos os bens particulares das entidades de colaboração vinculados imediatamente à execução dos serviços sociais, os quais, embora não insiram na noção de bem público do art. 98 do Código Civil - na medida em que não são do domínio nacional, não pertencendo a pessoas jurídicas de direito público interno -, estão, em nome da relevância pública do serviço e do princípio da dignidade da pessoa humana dos usuários do serviço, protegidos da excussão total por credores da entidade. Melhor explicando, embora tais bens estejam no comércio jurídico de direito privado, podendo ser objeto de quaisquer relações civis e comerciais e constritos para saldar as dívidas da entidade de colaboração com terceiros, é legítimo que, diante da sua penhora judicial, o parceiro privado oponha como defesa a necessidade de continuidade de suas atividades, evitando a interrupção-surpresa do seu funcionamento, em prejuízo dos usuários do serviço.

Reitere-se que, mais uma vez considerando que as prerrogativas e limitações exorbitantes não se supõem, dependendo de previsão legal que as instituam, não incluímos esses bens privados empregados na prestação dos serviços sociais na categoria dos bens extra comercium, inexistindo, a fortiori, qualquer norma jurídica que lhes confira essa condição, seja diretamente lhes atribuindo a natureza de bem público, seja consagrando o princípio da

\footnotetext{
${ }^{226}$ Neste sentido, o art. 22 da Lei Federal $n^{\circ}$ 13.019/2014 consigna que o plano de trabalho deverá conter a "descrição pormenorizada de metas quantitativas e mensuráveis a serem atingidas e de atividades a serem executadas, devendo estar claro, preciso e detalhado o que se pretende realizar ou obter, bem como quais serão os meios utilizados para tanto", além do "prazo para a execução das atividades e o cumprimento das metas".

${ }^{227}$ A Autora se refere aos bens particulares das concessionárias de serviço público, cujo raciocínio jurídico pode ser tranquilamente transposto para os bens particulares das entidades de colaboração, prestadoras que são de serviços de relevância pública.
} 
continuidade dos serviços ${ }^{228}$. Isso não quer dizer, entretanto, que, como visto, restrições à execução judicial desses bens não decorram diretamente do princípio da dignidade da pessoa humana dos usuários do serviço, bem como que a lei não lhes possa conferir outras proteções publicísticas, ou ainda que o Estado-instrumento não deva, diante do seu mister constitucional de garantia adequada da prestação das utilidades sociais, diligenciar para garantir a manutenção das atividades porventura prejudicadas com a excussão de bens da entidade de colaboração ${ }^{229}$.

Em terceiro, todo o patrimônio físico cedido pelo Poder Público ou adquirido com os recursos públicos transferidos ao parceiro privado ostenta natureza de verdadeiro bem público, vez que, a despeito de estar sujeito à gestão por entidades de colaboração, permanece sob o domínio do Estado ${ }^{230}$, devendo, em regra, como bem observa Walter Claudius ROTHENBURG (2007, p. 103), ser entregue à Administração Pública ao término do emparceiramento.

Para concluir o regime jurídico de prestação dos serviços sociais no âmbito dos contratos de colaboração, cumpre examinar a responsabilidade do Estado e da entidade de colaboração pelos danos causados aos particulares na execução dessas parcerias sociais entre os setores público e privado.

A responsabilidade [extracontratual ou aquiliana] das entidades de colaboração pelos danos causados aos particulares em geral (usuários ou não do serviço), importa o reconhecimento de que as atividades que integram o seu objetivo social e são objeto dos contratos de colaboração não ostentam a natureza de serviço público, tratando-se de atividades de relevância pública, não se lhes aplicando o $§ 6$ do art. 37 da Constituição

\footnotetext{
${ }^{228}$ Romeu Felpe BACELLAR FILHO (2007, p. 152) explica que, embora não os considere bens públicos por não pertencerem a pessoas jurídicas de direito público interno -, a maior parte da doutrina administrativista brasileira submete os bens particulares afetados à prestação de serviços públicos às proteções do Direito Público, em nome do princípio da continuidade do serviço público. Alexandre dos Santos ARAGÂO (2008, p.), na linha da doutrina francesa, diferencia propriedade pública - propriedade do Estado - de dominialidade pública - afetação aos interesses públicos, sujeitando também esta à incidência dum regime jurídico exorbitante. Indo além, Maria Sylvia Zanella DI PIETRO (2015, p. 94-95) entende que os bens particulares das concessionárias e permissionárias de serviço público vinculados à prestação do serviço delegado são verdadeiros bens públicos, estando fora do comércio jurídico de direito privado, tratando-se de característica inerente ao princípio da continuidade (arts. $6^{\circ}$ e 28 da Lei Federal n $\left.{ }^{\circ} 8.987 / 1995\right)$, com expressa referência no art. $7^{\circ}$ deste diploma legal.

${ }^{229}$ Mais uma vez, registre-se que a Lei Federal $\mathrm{n}^{\circ}$ 13.019/2014 consagra o dever estatal de garantir a continuidade dos serviços sociais prestados através dos termos de colaboração e de fomento, assumindo ou transferindo a execução do objeto da parceria a terceiro em caso de paralisação ou ocorrência de fato relevante (arts. 42, XXII, e 61, II).

${ }^{230}$ Trata-se do conceito civilista de bem público, assim considerado quando pertencentes às pessoas jurídicas de direito público interno (art. 98 do Código Civil).
} 
Federal. Sobre as entidades de colaboração, portanto, incide o regime jurídico civilista contido no art. 927, caput, c/c o art. 186, do Código de 2002, respondendo de forma subjetiva, sendo ônus dos particulares lesados a demonstração da culpa ou dolo do parceiro privado.

Alberto Shinji HIGA (2010, p. 232-242) debruçou-se sobre o tema, concluindo que a responsabilidade das entidades de colaboração - por ele chamados de agentes fomentados - é, em regra, subjetiva, justamente porque não prestam serviços públicos.

Demonstrando ser esse o entendimento majoritário dos doutrinadores brasileiros, observa o Autor, todavia, a divergência doutrinária existente em relação aos serviços sociais autônomos e as organizações sociais que celebram contrato de gestão com o Poder Público, decorrente de características especiais [supostamente] não presentes nas demais espécies de organizações da sociedade civil sem fins lucrativos: no primeiro caso, o dissenso decorre do recebimento de contribuições parafiscais pelos serviços sociais autônomos e pela sua criação dependente de lei (criadora ou autorizadora da criação); no segundo, por causa da existência de organizações sociais criadas com a finalidade de substituir o Estado no dever de prestação do serviço público ${ }^{231}$.

A celeuma envolvendo os serviços sociais autônomos não nos interessa diretamente, porque, como visto, eles não estão abrangidos pela noção de entidade de colaboração. Registre-se apenas que nos alinhamos àqueles que defendem a não aplicação da regra contida no $\S 6^{\circ}$ do art. 37 da Lei Maior Brasileira aos serviços sociais autônomos, mercê de não integrarem a Administração Pública e não prestarem serviços públicos.

Quanto às organizações sociais, Alberto Shinji HIGA (2010, 237-240) traz a posição de respeitável doutrina brasileira no sentido de que seria aplicável o $\S 6^{\circ}$ do art. 37 da Constituição Federal às organizações sociais em razão da finalidade de substituição do Estado por essas entidades na prestação de serviços públicos. O Autor encampa parcialmente esse raciocínio, ressalvando, contudo, a possibilidade de entidades sem fins lucrativos se qualificarem como OSs e celebrarem contrato de gestão com o Poder Público sem qualquer propósito de substituição do Estado na prestação de serviços públicos - não envolvendo destinação de bens públicos, recursos orçamentários e servidores públicos com ônus para origem -, caso em que estaríamos diante de verdadeira relação colaborativa, atuando a

${ }^{231} \mathrm{O}$ Autor aceita a premissa de que os serviços sociais, quando executados pelo aparato estatal, caracterizamse como serviço público, razão pela qual, se simplesmente transferidos à gestão das organizações sociais, não perderiam tal natureza jurídica, mantendo-se-lhes aplicado o art. 37, § 6 , da Constituição Federal. 
iniciativa privada apenas de forma complementar, incidindo, pois, o regime civilista de responsabilidade, em regra subjetiva.

Com o respeito de costume, não concordamos com a atribuição de responsabilidade objetiva às organizações sociais, pois: salvo previsões expressas na Constituição, não há, como visto na Primeira Parte desta dissertação, qualquer óbice constitucional à priorização dos meios indiretos de intervenção do Estado no domínio social, tratando-se de verdadeiro imperativo do princípio da subsidiariedade, de modo que a questionada substituição do aparato estatal pela iniciativa privada mostra-se legítima em nosso sistema jurídico, funcionando as benesses contidas na Lei Federal $n^{\circ}$ 9.637/1998 como efetivos instrumentos econômicos de fomento social; segundo porque as atividades sociais, cotitularizadas pela iniciativa privada e pelo Estado, se classificam, conforme amplamente discutido no presente trabalho, como serviços de relevância pública ainda quando executadas pelo Poder Público, motivo pelo qual, mesmo quando as OSs substituem o Estado na prestação de serviços sociais, não teria ocorrido a delegação de serviço público, estando, assim, afastada a incidência do $\S 6^{\circ}$ do art. 37 da Constituição a essas entidades de colaboração.

Sem embargo, valendo-se das lições de Alberto Shinji HIGA (2010, p. 234), entendemos possível a aplicação da responsabilidade objetiva às entidades de colaboração num caso: apenas em virtude de expressa previsão legal que objetivize o regime de responsabilidade dessas organizações, consoante admite o par. único do art. 927 do Código Civil, ou, ainda, por causa de regra publicística contida no instrumento colaborativo firmado com o Poder Público, estabelecida como contrapartida do parceiro privado ao recebimento do fomento estatal. O estabelecimento dessa restrição ao regime jurídico das entidades de colaboração se adéqua ao substrato material dos seus objetivos sociais, na medida em que visa a robustecer a proteção dos interesses públicos afetados à atividade, com maiores garantias à dignidade da pessoa humana.

Por sua vez, no que diz respeito à responsabilidade civil do Estado por danos causados pelas entidades de colaboração a terceiros, é Alberto Shinji HIGA (2010, p. 246255) quem mais uma vez sistematiza os entendimentos coincidentes e divergentes da doutrina brasileira sobre o tema, com vozes defendendo desde a total irresponsabilidade do Estado, passando pela sua responsabilização subsidiária, até o regime de solidariedade com a entidade de colaboração. 
Tendo em vista as premissas assentadas no presente trabalho, temos que não pode ser atribuído ao Estado a obrigação de reparar danos causados na execução de serviços sociais pela iniciativa privada sem fins lucrativos, mesmo quando contratado o regime de colaboração com o Poder Público. Sucede que tais organizações localizam-se fora da Administração, prestando, por direito próprio, serviços de relevância pública, sem qualquer instrumento de delegação do Estado, o qual, eventualmente, oferece oportunidade de emparceiramento para o fomento do setor social.

É esse o entendimento de Carolina Zancaner ZOCHUN (2008, p. 269), para quem “[...] Não há, nem mesmo, responsabilidade estatal subsidiária, já que a entidade é totalmente alheia à máquina estatal, bem como não se trata de prestadora de serviço público".

Por essas mesmas razões, Alberto Shinji HIGA (2010, p. 254-255) também se alinha no sentido da inexistência de responsabilidade do Estado pelos prejuízos causados a terceiros no âmbito dos contratos de colaboração, asseverando que:

O Estado, via de regra, não responde pelos danos causados pelos agentes fomentados a terceiros, no exercício das atividades objeto de fomento [através, por exemplo, dos contratos de colaboração aqui examinados], posto que essas pessoas jurídicas não integram a Administração Pública direta ou indireta do Estado e nem desempenham "serviços públicos", por delegação do Poder Público (autorização, permissão ou concessão"). Ao revés, desenvolvem "atividade econômica lato sensu", no âmbito da livre iniciativa ${ }^{232}$. A sua criação se dá por livre e espontânea vontade dos particulares.

Para o Autor (2010, p. 249-250), contudo, é possível a responsabilização excepcional do Estado, no caso de omissão [culposa] estatal em fiscalizar as atividades objeto do fomento público, cuja prestação deficiente tenha causado danos a terceiros. O seu raciocínio se constrói a partir da ideia de que o Estado possui dever de fiscalização em relação aos agentes fomentados, decorrente do seu poder-dever de polícia administrativa e da imposição contida em dispositivos legais específicos relativos às diversas espécies de contratos de colaboração ${ }^{233}$, dever jurídico esse que abrangeria todo o funcionamento do serviço executado pelo parceiro privado. Para ele, sobrevindo danos a terceiros no contexto

\footnotetext{
${ }^{232}$ Antecipe-se, inclusive, que uma das exigências que devem ser feitas às organizações da sociedade civil sem fins lucrativos para a celebração de contratos de colaboração é justamente a de tempo mínimo de existência e de atuação no ramo social objeto da parceria, o que reforça a noção de que essas entidades agem por direito próprio, no exercício de atividade não sujeita a qualquer reserva de exclusividade estatal, jamais enquanto braço do Poder Público.

${ }^{233}$ Verbi gratia, o art. $8^{\circ}$ da Lei Federal no 9.637/1998, o art. 11 da Lei Federal no 9.790/1999 e arts. $2^{\circ}$, VI, $8^{\circ}$ e 58-68, da Lei Federal no 13.019/2014.
} 
dos contratos de colaboração, provando o lesado que o Estado violou o seu dever de fiscalização do serviço (culpa do serviço), configurada estaria a responsabilidade subsidiária do Poder Público ${ }^{234}$.

Com a devida vênia, a construção do Autor merece algum reparo: a uma, porque o dever de fiscalização decorrente do poder-dever de polícia administrativa jamais atribuirá ao Estado a responsabilidade pelo funcionamento da atividade fiscalizada, apenas autorizandoo a interferir na esfera de liberdade dos agentes privados a fim de adequar as suas condutas à proteção do interesse público ${ }^{235}$; a duas, porque mesmo o dever de fiscalização estabelecido pela legislação que disciplina as diversas espécies de contratos de colaboração não importa o controle da organização e funcionamento do serviço social objeto da parceria, que continua sob a total gestão da entidade de colaboração, titular da atividade fomentada e única responsável pela sua execução ${ }^{236}$.

Temos, enfim, que todo o regime de prestação de serviços sociais através de contratos de colaboração repousa no reconhecimento de que o objeto desses vínculos formais de parceria são os serviços de relevância pública, submetidos, em princípio, ao regime de Direito Privado. Sem prejuízo, verifica-se que o substrato material de afetação aos interesses públicos e à dignidade da pessoa humana faz incidir uma disciplina jurídica diferenciada sobre a prestação não estatal desses serviços, permeada de deveres publicísticos extraídos diretamente da Constituição ou [necessariamente] fixados em leis e atos normativos infralegais, que se somam aos compromissos de interesse geral eventualmente assumidos por aquelas entidades privadas que [voluntariamente] resolvem se associar ao Poder Público para receber incentivos oficiais.

\footnotetext{
${ }^{234}$ Ele explica que o ordenamento jurídico pátrio não acolhe a teoria da equivalência das condições, mas, sim, aquela do dano direto e imediato ou da interrupção do nexo causal, consagrada no art. 403 do Código Civil de 2002 e sufragada pelo STF no RE $n^{\circ}$ 130.764/PR, somente se admitindo, então, a responsabilização subsidiária do Estado, e em caso de omissão culposa sua, quando violado o seu dever de fiscalização, cujo não exercício, atraso ou falha revelou-se determinante para a causação do dano, aplicando-se a teoria da culpa do serviço. ${ }^{235}$ Inclusive, se assim não fosse, o Estado viraria um verdadeiro "responsável subsidiário universal", na medida em que exerce a sua função administrativa de polícia sobre todas as atividades desenvolvidas pelo corpo social, agindo não apenas no domínio social, mas também no econômico.

${ }^{236}$ Os contornos do controle administrativo sobre o contrato de colaboração serão examinados em capítulo próprio a seguir.
} 


\section{DO REGIME DE CONTRATAÇÃO PELAS ENTIDADES DE COLABORAÇÃO}

O regime de contratação pelas entidades de colaboração, de obras, serviços, compras, alienações e pessoal pelas entidades de colaboração deverá observar, no que tange aos recursos públicos repassados, os princípios que norteiam a gestão do patrimônio público.

Trata-se de decorrência imediata da natureza pública dos recursos repassados, que assim se mantêm mesmo quando submetidos à gestão privada pelo parceiro privado do Estado, permanecendo vinculados às finalidades às finalidades de interesse coletivo que justificam a relação colaborativa travada entre a Administração e a iniciativa privada sem fins lucrativos.

É o posicionamento de Janaina SCHOENMAKER (2011, p. 61-62), esta que adverte que, se os convênios já foram utilizados como simples instrumento de repasse de recursos públicos a fundo perdido, hoje constam do seu regime jurídico a disciplina dos meios para seu efetivo controle, mormente porque o valor repassado ao particular não perde sua natureza de dinheiro público ${ }^{237}$.

Com efeito, embora coordenados pela entidade de colaboração naquilo que se intitula gestão privada de recursos públicos, o patrimônio público repassado (financeiro e não financeiro) estarão sujeitos a um regime jurídico privado derrogado por normas publicísticas, aproveitando-se, dum lado, da flexibilidade dos procedimentos de contratação editados pelos próprios parceiros privados do Estado, e sujeitando-se, d'outro, às diretrizes cogentes do new public management, orientando-se pela eficiência, foco nos resultados, flexibilidade de meios e prestação de contas (accountability) (Humberto Falcão MARTINS, 2005, p. 07).

No que diz respeito à contratação de obras, serviços, compras e alienações com os recursos repassados através dos contratos de colaboração, Gustavo Justino de OLIVEIRA (2008, p. 36-39) aponta os seguintes argumentos para afastar a regra constitucional da licitação pública: (i) o inciso XVIII do art. $5^{\circ}$ da Constituição Federal veda toda sorte de interferência estatal no funcionamento das associações ${ }^{238}$; e (ii) o inciso XXVII do art. 22 e

${ }^{237}$ Da mesma forma, Gustavo Justino de OLIVEIRA (2007c, p. 231), Maria Sylvia Zanella DI PIETRO (2013, p. 348) e Maria Nazaré Lins BARBOSA (2011, p. 535).

${ }^{238}$ Consideramos, contudo, que esse fundamento não tem o condão de, per se, liberar as entidades não estatais que administram recursos públicos dos princípios que norteiam a gestão do patrimônio público, não se devendo 
o inciso XXI do art. 37, da Constituição Federal, restringem a licitação pública aos órgãos e entidades administrativas, e tais organizações da sociedade civis não se enquadram no aparelho estatal. O Autor acrescenta, ainda, que, para os termos de parceria celebrados com a OSCIPs, a legislação federal de regência (norma especial) traz previsão específica que rechaça qualquer confusão com a regra da licitação pública (art. 14 da Lei Federal no 9.790/1999) - igualmente constante do art. 43 da Lei Federal n ${ }^{\circ}$ 13.019/2014, valendo, por conseguinte, também para os recentes termos de colaboração e de fomento.

No plano normativo nacional, a redação originária da Instrução Normativa STN $n^{\circ}$ 01/1997 desobrigava as entidades privadas sem fins lucrativos que celebrem convênios de natureza financeira com a Administração de realizar licitação nos termos da Lei Federal n ${ }^{\circ}$ 8.666/1993 para a contratação de bens e serviços e para compras em geral com os recursos públicos transferidos, apenas referindo a necessidade de adoção de procedimentos análogos aos dessa $\operatorname{Lei}^{239}$.

Ocorre que o TCU, no Acórdão 1.070/2003, veio a modificar a sua posição em relação às transferências voluntárias feitas às entidades sem fins lucrativos por meio de convênios e outros instrumentos congêneres, determinando que o Secretário da Secretaria do Tesouro Nacional modificasse o teor do art. 27 da aludida Instrução Normativa para fazer constar a submissão da aplicação dos recursos públicos geridos por particulares à Lei Federal $n^{\circ} 8.666 / 1993$. Foi nesse exato contexto que se editou a Instrução Normativa STN $n^{\circ}$ 03/2003, a qual, alterando a redação do art. 27 da IN/STN no 01/1997, estabeleceu que a entidade privada convenente, quando da execução de despesas com os recursos transferidos, sujeitar-se-á às disposições da Lei Federal no 8.666/1993, admitida a modalidade do pregão prevista na Lei Federal no 10.520/2002. Nesse mesmo trilhar, a Presidência da República fez publicar o Decreto Federal no 5.504/2005, estabelecendo a exigência de utilização do pregão, preferencialmente na forma eletrônica, as contratações de bens e serviços comuns com

enxergar a sujeição aos respectivos princípios constitucionais como uma ingerência estatal constitucionalmente vedada.

${ }^{239}$ Essa redação primeira da IN/STN n ${ }^{\circ}$ 1/1997 estava afinada com o entendimento firmado pelo TCU na Decisão n ${ }^{\circ}$ 907/1997, em que se examinou a situação dos serviços sociais autônomos, os quais, embora não se enquadrem na noção de entidade de colaboração [pela ausência de voluntariedade e por possuir fins mútuos ou corporativos], também administram recursos públicos vinculados a uma finalidade de interesse público [ainda que não sejam entidades de fins comunitários, que servem desinteressadamente toda a coletividade]. Nesta oportunidade, o Plenário da Corte de Contas Federal entendeu que “...os Serviços Sociais Autônomos não estão sujeitos à observância aos estritos procedimentos estabelecidos na Lei nº 8.666/93, e sim aos seus regulamentos próprios devidamente publicados, consubstanciados nos princípios gerais do processo licitatório.” 
recursos públicos federais objeto de transferência voluntária a entidades privadas por meio de convênios e instrumentos congêneres ${ }^{240}$.

Finalmente, sobreveio Decreto Federal $n^{\circ}$ 6.170/2007, estipulando em seu art. 11 que, para efeito do art. 116 da Lei Federal $n^{\circ}$ 8.666/1993, a aquisição de produtos e a contratação de serviços com recursos federais transferidos a entidades privadas sem fins lucrativos deverão observar os princípios da impessoalidade, moralidade e economicidade, sendo necessária, no mínimo, a realização de cotação prévia de preços no mercado. Neste ponto, restou tacitamente revogado o aludido Decreto Federal $n^{\circ} 5.504 / 2005$, liberando-se as entidades de colaboração, em todo e qualquer instrumento de parceria com o Estado, da realização de licitação pública ${ }^{241}$.

No que respeita aos contratos de gestão com as organizações sociais federais, $\mathrm{o}$ art. 17 da Lei Federal nº 9.637/1998 expressamente desobriga as OSs de realizar licitação para a contratação de obras e serviços e realizar compras, com os recursos públicos repassados, fixando que a entidade privada deverá, no prazo máximo de 90 (noventa) dias, editar regulamento próprio prevendo os procedimentos que adotará neste sentido, os quais, em virtude do teor do caput do art. $7^{\circ}$ da Lei, deverão observar os princípios da legalidade, impessoalidade, moralidade, publicidade e economicidade, os quais possuem status constitucional (art. 37, caput) e reclamam a observância de critérios objetivos na contratação de terceiros pelas organizações sociais, gestoras de recursos públicos que são.

Assim também prevê o art. 14 da Lei Federal nº 9.790/1999, determinando que a OSCIP publique, no prazo máximo de 30 (trinta) dias da assinatura do instrumento colaborativo, regulamento próprio contendo os procedimentos que adotará para a contratação de obras, serviços e compras com emprego dos recursos públicos transferidos, observando-se os princípios do inciso I do art. $4^{\circ}$ da Lei, quais sejam a legalidade,

\footnotetext{
${ }^{240}$ Carlos Ari SUNDFELD e Rodrigo Pagani de SOUZA (2011, p. 74) observam que o art. $1^{\circ}$ do Decreto Federal $\mathrm{n}^{\circ} 5.504 / 2005$ partia do equivocado pressuposto de que o art. 116 do Estatuto Geral de Licitações e Contratos Administrativos somente restaria atendido se as entidades privadas sem fins lucrativos parceiras do Estado realizassem licitação. Para eles, tal dispositivo legal jamais levou a exigência nesse sentido, limitandose a dizer que as disposições da Lei se aplicam naquilo que couber, estando as entidades não estatais, inclusive, expressamente excluídas do alcance da Lei Federal nº 8.666/1993 em virtude da redação do par. único do seu art. $1^{\circ}$.

${ }^{241}$ Registre-se as Portarias Interministeriais MP/MF/CGU n ${ }^{\circ}$ s 107/2008 e 507/2011 também estabelecem, em seus arts. 45 e 57, respectivamente, a suficiência de cotação prévia de preços no mercado. Não custa lembrar, entretanto, como bem adverte Maria Sylvia Zanella DI PIETRO (2015, p. 246), que, diante do art. 84 da Lei Federal $n^{\circ}$ 13.019/2014, o alcance desses atos legislativos em relação aos convênios [e instrumentos congêneres] celebrados pela Administração com entidades da sociedade civil sem fins lucrativos ficou bastante limitado, substituídos que foram tais vínculos formais de parceria pelos termos de colaboração e de fomento previstos na Lei.
} 
impessoalidade, moralidade, publicidade, economicidade e eficiência. Aplicam-se a esses termos de parceria a mencionada Portaria Interministerial MP/MF/CGU no 507/2011 e aquelas disposições da Lei Federal no 13.019/2014 que forem compatíveis com a Lei das $\operatorname{OSCIPs}^{242}$.

A despeito da clara redação da Lei das OSCIPs, alguma controvérsia surgiu em razão do disposto no art. 62 da Portaria Interministerial MP/MF/CGU n 507/2011 - que repetiu o art. 49 da Portaria Interministerial MP/MF/CGU n 127/2008 -, que determinou a observância das disposições da Lei Geral de Licitação e obrigou, para a aquisição de bens e serviços comuns com os recursos repassados nos termos de parceria, o uso da modalidade pregão de licitação (Lei Federal n ${ }^{\circ}$ 10.520/2002), conforme estabelecido no Decreto Federal $\mathrm{n}^{\mathrm{o}}$ 5.505/2005. Ocorre que a doutrina majoritária logo percebeu a ilegalidade/inconstitucionalidade da extensão promovida pela aludida Portaria c/c esse Decreto de 2005, a exemplo de Gustavo Justino de OLIVEIRA (2008, p. 36-39), cujas razões já foram expostas neste trabalho ${ }^{243}$.

Finalmente, a novel Lei Federal no 13.019/2014 define em seu art. 43 que as contratações de bens e serviços pelas organizações da sociedade civil sem fins lucrativos feitas com recursos públicos transferidos por força dos termos de colaboração e de fomento [e termos de parceria com as OSCIPs, nos termos do art. $4^{\circ}$ da Lei] estão sujeitas aos princípios da licitação (legalidade, moralidade, boa-fé, probidade, impessoalidade, economicidade, eficiência, isonomia, publicidade, razoabilidade, julgamento objetivo e busca permanente pela qualidade e durabilidade), devendo as entidades privadas sem fins lucrativos parcerias elaborar regulamento de compras e contratações, necessariamente aprovado pela Administração e constante do anexo do instrumento de parceria ${ }^{244}$. Não custa

\footnotetext{
${ }^{242}$ Assim concluiu parcialmente o STF no julgamento da ADI n 1.923/DF, entendendo-se que "os contratos a serem celebrados pela Organização Social com terceiros, com recursos públicos, [devem] sejam conduzidos de forma pública, objetiva e impessoal, com observância dos princípios do caput do art. 37 da CF, e nos termos do regulamento próprio a ser editado por cada entidade" (Luiz FUX, 2011, p. 35). Valem aqui os mesmos argumentos trazidos por Gustavo Justino de OLIVEIRA (2008, p. 36-37), no sentido de que a exigência de licitação pública para as contratações realizadas pelas entidades privadas sem fins lucrativos afronta a Constituição Federal, nomeadamente os seus arts. 22, XXVII, 37, XXI, e 5º XVIII.

${ }^{243}$ Consoante já explicado, a referida portaria traz em seu art. 62 a necessidade de observância das disposições da Lei Federal no 8.666/1993, cuja aplicação restou definitivamente afastada em relação aos termos de parceria com as OSCIPs em virtude do disposto no art. $4^{\circ}$, c/c o art. 84, da novel Lei Federal n 13.019/2014.

${ }^{244}$ Registre-se que, para os serviços sociais autônomos [cujo razão de decidir, repita-se, pode ser transposta para o caso das entidades de colaboração], o TCU vem entendendo, conforme fixado no Acórdão $\mathrm{n}^{\circ}$ $6.483 / 2009$, ser indispensável que seus regulamentos de compras e contratações prevejam a necessidade do terceiro contratado apresentar comprovantes de regularidade fiscal, além de outras certidões que demonstrem a sua idoneidade jurídica. Segundo pensamos, tal exigência é desproporcional e desarrazoada, na medida em que extrapola os limites dos princípios da licitação e vai de enontro à natureza jurídica colaborativa dessas
} 
lembrar que o art. 84 da Lei Federal n 13.019/2014 extirpou do nosso ordenamento jurídico os convênios administrativos colaborativos [entre o Poder Público e os particulares, enquanto instrumento de parceria] - salvo no que diz respeito aos convênios no âmbito da saúde, por força do seu assento constitucional (art. 199, § $1^{\circ}$ ) -, bem como determinou a não aplicação da Lei Federal no 8.666/1993 e de toda a legislação referente a convênios às relações de fomento e de colaboração por ele regidas, previsão esta que se aplica aos termos de parceria com as OSCIPs em virtude da regra de extensão contida no art. $4^{\circ}$ desse novel diploma normativo.

Temos, enfim, que o ordenamento jurídico brasileiro vigente determina que toda e qualquer entidade de colaboração edite regulamento próprio de contratação de terceiros com os recursos públicos transferidos em razão da relação pública colaborativa, a ser devidamente aprovado pelo órgão ou entidade administrativa parceira. Trata-se de verdadeiro requisito de habilitação da entidade, ainda que, eventualmente, tal como feito na parte final do art. 43 da Lei Federal $n^{\circ}$ 13.019/2014, se admita a sua elaboração após a celebração do respetivo instrumento de parceria.

Sem prejuízo, revela-se salutar que a Administração Pública, em determinados casos, sufrague a previsão de mecanismos especialmente simplificados nesse regulamento de contratação, como na hipótese de despesas comuns de pequeno valor, as quais, de acordo com José Eduardo Sabo PAES (2013, p. 809-810), não comportam a emissão de cheques nominativos, devendo essas despesas miúdas - cujo valor não poderia ultrapassar, dentro do exercício financeiro como um todo, o limite contido no inciso I do art. 24 da Lei Federal $\mathrm{n}^{\circ}$ 8.666/1993 - ser executadas por meio da sistemática de "suprimento de fundos"245, ressalvando-se que as notas fiscais e ou recibos respectivos devem integrar as correspondentes prestações de contas.

Especificamente sobre o regulamento próprio de obras, serviços, compras e alienações ora tratado, a Plataforma por um Novo Marco Regulatório para as Organizações da Sociedade Civil (2014, p. 11-12) revela preocupação com a "abertura para a interferência estatal na liberdade de auto-organização" das organizações da sociedade civil, especialmente

parcerias nos setores sociais, praticamente fazendo das entidades de colaboração verdadeiros braços da Administração Pública.

${ }^{245}$ De acordo com o Glossário do Senado Federal, trata-se de "Instrumento de execução ao qual pode recorrer o ordenador de despesas para, através de servidor subordinado, realizar despesas que, a critério da administração e consideradas as limitações previstas em lei, não possam ou não devam ser realizadas por via bancária”. 
diante da falta de padronização entre os diversos entes públicos, sendo grande a chance que cada um estabeleça requisitos diversos e até mesmo contraditórios, de difícil implementação dentro duma mesma organização, gerando uma fragmentação indesejável às instituições privadas. A Plataforma defende, então, que norma infralegal regulamentadora minimize a abrangência dos temas que podem ser objeto de análise pela Administração e crie um padrão e referência que guie as organizações da sociedade civil e os gestores públicos no processo de elaboração desse regulamento.

Por outro lado, entendemos que a contratação de pessoal pelas entidades de colaboração com os recursos públicos repassados através da parceria não se sujeita à regra constitucional do concurso público (art. 37, II), restrita que está à investidura em cargo ou emprego público, isto é, aos órgãos administrativos; nem ao teto salarial imposto pelo art. 37, XI, também limitado à remuneração e subsídio de cargos, empregos e funções públicas $^{246}$.

Não foi esse, contudo, o entendimento firmado pelo TCU no Acórdão $n^{\circ}$ 11.111/2008, no qual se entendeu que as OSs se sujeitam à observância e aplicação dos princípios que regem a Administração na gestão dos recursos públicos repassados, delas se exigindo a utilização de "critérios objetivos de seleção de pessoal, assegurando a isonomia entre os interessados, a impessoalidade, a transparência e publicidade dos procedimentos, abstendo-se de adotar critérios subjetivos, tal como avaliação psicológica”.

Embora não se trate de concurso público propriamente dito, a exigência de procedimento objetivo de seleção de pessoal pelas entidades de colaboração revela-se desarrazoada. Se a cobrança de certame [diverso de licitação pública] parece adequada para a contratação de obras, serviços, compras e alienações, ela acaba por desvirtuar a natureza privada da entidade de colaboração quando se trata da seleção de pessoal, quebrando a

\footnotetext{
246 Natasha Schmitt Caccia SALINAS (2008, p. 170) observa a controvérsia existente neste particular entre o Ministério Público junto ao TCU e a própria Corte de Contas Federal: para o Parquet, a remuneração dos funcionários e dirigentes da entidade privada, quando efetuado com recursos públicos, não poderia ser superior, em seu valor bruto, ao limite estabelecido para a remuneração dos servidores do Poder Executivo Federal; para o TCU (Acórdão $n^{\circ}$ 1.777/2005), a imposição de limite remuneratório atrelado ao teto constitucional do serviço público não se harmoniza com um "sistema voltado para o desempenho global do projeto, com a atenção apontada para os resultados". Registre-se, contudo, que a sujeição ao teto constitucional foi encampada pela Lei Federal no 13.019/2014, constando expressamente da alínea "a" do inciso I do art. 46 que a remuneração da equipe dimensionada no plano de trabalho com os recursos públicos vinculados à parceria não poderá superar o teto do Poder Executivo. Consideramos equivocada esta previsão da novel Lei de Parcerias, seja prque se trata de regra constitucional adstrita aos órgãos e entidades públicas, seja porque o parâmetro do valor de mercado da região que consta da mesma alínea do referido dispositivo legal já se revela suficiente ao respeito dos princípios publicísticos, possuindo, ainda, o condão de evitar dificuldades na contratação de funcionários em áreas de notória especialização em que o teto remuneratório do Poder Executivo seja inferior.
} 
imanente pessoalidade e subjetividade do trabalho prestado pelos funcionários da entidade, extrapolando a sujeição da gestão [privada] dos recursos públicos repassados aos princípios publicísticos. É dever ainda contraditório, uma vez que a entidade privada deve comprovar existência própria, com qualificação técnica e idoneidade financeira, para se emparceirar com o Estado, o que pressupõe obviamente quadro de funcionários já contratados pela organização privada.

Isso não significa dizer, entretanto, que a contratação de pessoal pelas entidades de colaboração não está submetida a restrições publicísticas. Com efeito, parece razoável, em nome do princípio da transparência, que o quadro de pessoal da entidade, com os respectivos valores das remunerações pagas, seja devidamente descrito no plano de trabalho apresentado pelo parceiro não estatal e necessariamente aprovado pela Administração Pública. Os princípios publicísticos, outrossim, especialmente o da moralidade, impessoalidade, eficiência e economicidade, reclamam a imposição de limitações salariais aos funcionários da entidade - especialmente aos seus dirigentes -, devendo a remuneração paga ser compatível com os valores praticados no mercado da região em que atua a entidade. Isso não quer dizer, veja bem, que os salários pagos deverão estar submetidos ao teto constitucional do funcionalismo público.

Nesse sentido, registre-se que a recente Lei de Parcerias Sociais não exige a realização de procedimento objetivo de seleção de pessoal. O seu art. 46, outrossim, traz expressamente a possibilidade de utilização dos recursos vinculados à parceria para o pagamento da remuneração da equipe dimensionada no plano de trabalho, desde que os respectivos valores: correspondam às atividades previstas para a consecução do objeto e à qualificação técnica da função desempenhada; sejam compatíveis com o valor de mercado da região onde atua e não superior ao teto constitucional; e sejam proporcionais ao tempo de trabalho efetiva e exclusivamente dedicado à parceria celebrada. Como referido, todavia, parece-nos indevida sujeitar a remuneração dos funcionários das entidades de colaboração ao teto do funcionalismo público, sendo ainda mais absurda a exigência de exclusividade do trabalho em favor da parceria, como se a vedação constitucional da cumulação de cargos públicos (art. 37, XVI) fosse aplicável fora do aparato estatal. 


\section{DO REGIME DE CONTROLE}

O regime de controle do contrato de colaboração diz respeito tanto ao controle exercido sobre a ação do órgão ou entidade administrativa parceira quanto aquele que recai sobre conduta da entidade de colaboração, desde a celebração, passando pela execução e chegando à conclusão do instrumento de parceria.

O fenômeno crescente do emparceiramento social entre os setores público e privado, com a transferência de recursos públicos à gestão de entidades não estatais, amplia o campo de incidência do controle administrativo para além das estruturas formais do Estado, atingindo justamente as entidades de colaboração.

É essa a lição de Paulo Eduardo Garrido MODESTO (2011, p. 06), para quem o atual Direito Administrativo "também é aplicado a entidades privadas que não realizem função administrativa, não são delegadas do Estado, nem manifestam poderes públicos, mas que firmam voluntariamente com o Poder Público vínculos de parceria e fomento essenciais ao desenvolvimento da própria coletividade e à justiça social, pois viabilizam a concretização de direitos fundamentais".

Nesse trilhar, do ponto de vista estrutural do controle administrativo, a gestão privada de recursos públicos transferidos mediante contrato de colaboração sujeita-se aos órgãos de controle interno e externo da Administração ${ }^{247}$, além, é claro, da estrutura de fiscalização do próprio parceiro privado ${ }^{248}$.

$\mathrm{O}$ controle administrativo interno vem tradicionalmente conceituado como o realizado no interior da Administração Pública sobre seus próprios órgãos e entidades,

\footnotetext{
${ }^{247}$ Quanto à origem, o controle administrativo se classifica em interno e externo. O interno é o praticado dentro da própria estrutura da Administração, pelo órgão ou entidade responsável pela atividade controlada. O externo, por sua vez, é aquele exercido por estrutura externa à unidade administrativa responsável pelo ato/procedimento controlado, a exemplo daquele realizado pelo Legislativo, Tribunal de Contas, Judiciário e sociedade civil (controle social.)

${ }^{248}$ As leis que disciplinam as diversas espécies de contrato de colaboração chegam a exigir estruturas internas de controle das organizações da sociedade civil sem fins lucrativos que pretendem se emparceirar com o Poder Público no desenvolvimento de atividades sociais. Exemplificativamente, a Lei Federal n ${ }^{\circ}$ 9.637/1998 exige das candidatas ao título de OS a existência de conselho de administração e diretoria enquanto órgãos de deliberação superior e de direção, com representantes do Poder Público (art. 2º, I, "c" e "d"); a Lei Federal no 9.790/1999 condiciona a outorga do certificado de OSCIP à constituição de conselho fiscal ou órgão equivalente no estatuto da entidade, com atribuição de acompanhar e opinar sobre o desempenho financeiro e contábil e operações patrimoniais (art. $4^{\circ}$, III), regra repetida no art. 33, II, da Lei Federal no 13.019/2014, como requisito para a organização da sociedade civil sem fins lucrativos celebrar termos de colaboração e de fomento com a Administração.
} 
tratando-se da "fiscalização que a mesma exerce sobre os atos e atividades de seus órgãos e das entidades descentralizadas que lhe são vinculadas" (Odete MEDAUAR, 2012, p. 49) ${ }^{249}$. Transpondo-se essa noção para os contratos de colaboração, trata-se daquele exercido pela própria estrutura da Administração parceira, inclusive por seus órgãos especializados de competência fiscalizatória ${ }^{250}$.

Por sua vez, o controle externo é aquele praticado por órgãos localizados fora do corpo da Administração Pública, com destaque para a atuação do Tribunal de Contas, a quem a Constituição Federal atribui expressamente a tarefa de "fiscalizar a aplicação de quaisquer recursos repassados pela União mediante convênio, acordo, ajuste ou outros instrumentos congêneres, a Estado, ao Distrito Federal ou a Município” (art. 71, VI). Não é de se desconsiderar, ainda, a competência constitucional fiscalizatória do Ministério Público (arts. 127, caput, e 129, II e III), a atuação do Poder Judiciário e a importância do chamado controle social.

Sob a perspectiva do método, os contratos de colaboração se submetem aos controles administrativos formal e material: o controle formal é aquele pautado na verificação da legitimidade (adequação às regras e princípios jurídicos) e do mérito ${ }^{251}$ dos atos e procedimentos, ao passo que o controle material se volta a aferir o resultado da ação administrativa (Floriano de Azevedo MARQUES NETO, 2010, p. 212).

Como já assentado na Primeira Parte deste trabalho, longe de representar a superação do controle de meios pelo de resultados, o paradigma gerencial de Administração Pública reclama a combinação do controle formal com o material, numa extensão que

\footnotetext{
${ }^{249}$ A Constituição Federal, em seu art. 74, estabelece que que os Poderes Legislativo, Executivo e Judiciário deverão manter sistema de controle interno, com a finalidade de, dentre outras, "comprovar a legalidade e avaliar os resultados, quanto à eficácia e eficiência, da gestão orçamentária, financeira e patrimonial nos órgãos e entidades da administração federal, bem como da aplicação de recursos públicos por entidades de direito privado" [Grifo nosso].

${ }^{250}$ No âmbito federal, é o caso da Controladoria Geral da União, à qual, nos termos do art. 17 da Lei Federal $\mathrm{n}^{\mathrm{o}} 10.683 / 2003$, "compete assistir direta e imediatamente ao Presidente da República no desempenho de suas atribuições quanto aos assuntos e providências que, no âmbito do Poder Executivo, sejam atinentes à defesa do patrimônio público, ao controle interno, à auditoria pública, à correição, à prevenção e ao combate à corrupção, às atividades de ouvidoria e ao incremento da transparência da gestão no âmbito da administração pública federal".

${ }^{251}$ Como bem ensina Odete MEDAUAR (2012, p. 65), quanto ao aspecto da atuação controlada, o controle formal se divide em controle de legalidade [legitimidade] e controle de mérito, expandindo-se a fiscalização para além da letra fria da lei. Para a Autora, embora continue a se tratar de controle essencialmente formal, de conferência de documentos, planos e projetos de trabalho, a referência de mérito vem acrescentar a necessidade de consonância do objeto controlado com as prioridades eleitas no âmbito da atividade de planejamento estatal, de cariz marcadamente político e jamais refratário à participação social.
} 
incorpora à ação administrativa ideais de legitimidade, responsividade e eficiência ${ }^{252}$, afastando-se respeito cego às regras e princípios procedimentais ${ }^{253}$.

Nessa toada, Floriano de Azevedo MARQUES NETO (2010, p. 212) destaca que a verificação do atendimento dos procedimentos e requisitos legais, embora não seja o foco da Administração Pública Contemporânea, é uma imposição do nosso ordenamento jurídico, além de verdadeiro instrumento de inibição de desvios e de reforço da segurança jurídica ${ }^{254}$. Para ele, outrossim, a proeminência do controle material não traduz uma legitimação pelo resultado, como se fosse possível sanar falhas graves procedimentais em razão do atendimento das finalidades públicas traçadas ${ }^{255}$.

Sobre o inafastável equilíbrio entre os controles de meios e de resultados nas parcerias sociais entre os setores público e privado, preciosas são as lições de Carlos Ari SUNDFELD e Rodrigo Pagani de SOUZA (2011, p. 52-53):

[...] Se antes, na parceria tradicional, não importava tanto um controle de resultados (até porque sequer havia resultados bem definidos cujo alcance se pudesse exigir), importando - isto, sim - um controle de meios ou burocrático, focado na gestão de recursos financeiros e na sua aplicação ao objeto, algo diverso

252 Diogo de Figueiredo MOREIRA NETO (2014, p. 87-91) demonstra a relação direta existente entre os princípios substanciais da democracia (origem do poder no povo, que atribui a administração dos seus interesses e recursos ao Estado, o qual, por sua vez, deve sempre obedecer a essa vontade política primária) e da juridicidade (de submissão do agir da Administração Pública a toda a ordem jurídica, abrangente da legalidade, legitimidade e moralidade) com aqueles instrumentais da publicidade (abertura da coisa pública ao conhecimento de todos), responsabilidade (dever de prestação e de tomada de contas com foco na legalidade estrita), responsividade (dever jurídico autônomo de atendimento adequado das demandas da sociedade) e sindicabilidade (possibilidade de submeter quaisquer lesão ou ameaça de lesão de direito a algum tipo de controle), este último sem o qual "todo o sistema jurídico ficaria inerte e frustro", na medida em que garante o respeito a todos os demais princípios. Em arremate, afirma o Autor que "a sindicabilidade da responsividade dependerá também da qualidade do que se tem denominado de transparência (ou visibilidade) da gestão administrativa e, por isso, a publicidade é igualmente instrumental tanto para a responsabilidade quanto para a responsividade" [grifos no original].

${ }^{253}$ Vanice Lírio do VALLE (2008, p. 57-58) chama a atenção para a falsa dicotomia muitas vezes apontada entre o controle de meios e o controle de resultados. De acordo com a Autora, a despeito dos excessos formais e anacronismos do modelo burocrático tradicional, concepção gerencial de Administração Pública não olvida da a avaliação sistemática de procedimentos, da recompensa pelo desempenho e da capacitação permanente, características da boa administração burocrática, às quais se acrescentam os princípios da orientação para o cidadão-cliente, do controle por resultados e da competição administrada.

${ }^{254}$ Assim também entendeu o TCU no Acórdão no 2.640/2008, estabelecendo "que a transferência do foco da ação fiscalizadora (que passaria a privilegiar o controle de resultados) não importa no [sic] abandono ou enfraquecimento dos controles da legalidade, da forma da execução das despesas e do uso regular dos recursos públicos”. Nessa toada, a Corte de Contas Federal estabeleceu que a prestação de contas [dos contratos de gestão] não pode se resumir à demonstração da consecução dos objetivos estratégicos, metas e indicadores constantes do plano de trabalho, devendo conter também a forma como se deu a aplicação da totalidade dos recursos públicos repassados.

255 Isso vale, inclusive, para os equívocos formais de pequena importância, os quais nunca devem ser negligenciados, merecendo, ao revés, um olhar cuidadoso dos órgãos de controle, que devem adotar uma postura de diálogo, preocupando-se mais em orientar os gestores do patrimônio público do que em puni-los, voltando-se para o futuro, na construção concertada de boas práticas administrativas. 
se passa com o controle das parcerias modernas. Nestas, importa sobremaneira o controle de resultados - ou seja, o controle do cumprimento de todas e cada uma das obrigações pactuadas, bem como a avaliação do desempenho do executor quanto ao alcance das metas estabelecidas -, de sorte que a efetiva realização do objeto pactuado, a apresentação dos resultados almejados, constitui indício relevante da escorreita aplicação dos recursos.

$[\ldots]$

[...] Seus gastos continuam a ter de realizar-se segundo padrões de probidade e moralidade - e este controle de gastos continua relevante, por certo -, mas a verificação da efetiva execução do objeto pactuado ganhou proeminência.

Registre-se que a própria Lei Federal no 13.019/2014 consignou expressamente a composição adequada dos controles formais e materiais ao disciplinar a prestação de contas a cargo das organizações da sociedade civil parceiras do Estado:

Art. $2^{\circ}$. [...]

$[\ldots]$

XIV - prestação de contas: procedimento em que se analisa e se avalia a execução da parceria quanto aos aspectos de legalidade, legitimidade, economicidade, eficiência e eficácia, pelo qual seja possível verificar o cumprimento do objeto da parceria e o alcance das metas e dos resultados previstos, compreendendo 2 (duas) fases:

a) apresentação das contas, de responsabilidade da organização da sociedade civil; b) análise e manifestação conclusiva das contas, de responsabilidade da administração pública, sem prejuízo da atuação dos órgãos de controle;

A grande dificuldade do controle gerencial do contrato de colaboração é a delimitação da sua incidência sobre a gestão privada dos recursos públicos ${ }^{256}$ repassados ao parceiro privado, que demanda a compatibilização da liberdade constitucional de organização e funcionamento das associações privadas (art. $5^{\circ}$, XVIII) com os também fundamentais imperativos da proteção do patrimônio público, notadamente com os princípios do caput do art. 37 da nossa Lei Maior, com o dever de prestação de contas aos órgãos de controle administrativos (arts. 70-75) e com a sujeição à ação fiscalizatória do Ministério Público (art. 129, II e III).

\footnotetext{
${ }^{256}$ Humbert Falcão MARTINS (2005, p. 03-05) leciona que a gestão de recursos públicos é o conjunto estruturado de regras e atividades que envolvem quatro subsistemas ou momentos lógicos essenciais (não necessariamente sequenciais): (i) planejamento: dimensionamento qualitativo e quantitativo dos recursos públicos necessários; (ii) prospecção e provisão: definição da disponibilidade ou identificação prospectiva da oferta e condições de provisão dos recursos públicos necessários; (iii) aplicação e manutenção: estrutura de decisões alocativas (autorizativas e executivas) para aplicação dos recursos nas atividades pertinentes e sua devida manutenção); e (iv) controle: registro, monitoramento e avaliação de recursos públicos relativamente à conformidade (às regras de provimento, aplicação e manutenção) e desempenho (contribuição para geração dos resultados visados).
} 
No que diz respeito ao controle formal dos contratos de colaboração, cumpre rejeitar qualquer espécie de transformação das entidades [privadas] de colaboração em braços do Estado, sujeitando-as ao regime jurídico administrativo estrito, de verificação dos requisitos e procedimentos legais próprios das repartições públicas ${ }^{257}$.

Com efeito, o controle de meios incidente sobre as entidades privadas parceiras do Estado $^{258}$ deve se limitar à conferência da boa aplicação dos recursos públicos transferidos, naquilo que se intitula controle moderado ou flexibilizado de legalidade, por meio do qual se exige não a observância das regras administrativas propriamente ditas, mas tão somente dos princípios e valores de ordem pública na condução de seus procedimentos ${ }^{259}$.

Esse controle formal envolve, ainda, a conferência do mérito da ação administrativa de fomento, verificando a compatibilidade das parcerias entabuladas com os programas definidos pelo planejamento estatal, demandando uma análise minuciosa do plano de trabalho apresentado pelas organizações privadas.

Em relação ao controle material, por sua vez, Mario Mora QUIRÓS (2006, p. 170) esclarece que ele pressupõe a consolidação gradual dum modelo de gestão pública flexível e criativo, pautado em três processos indispensáveis à chamada cultura pública orientada pelos resultados: (i) programação: alocação dos recursos conforme as prioridades nacionais e as demandas sociais; (ii) execução: fixação de metas, acompanhamento dos programas e estabelecimento de controles seletivos para orientar a tomada de decisões; e (iii) avaliação: medição do desempenho público em função dos resultados, colocando-se em prática o dever de prestação de contas.

\footnotetext{
${ }^{257}$ Paulo Eduardo Garrido MODESTO (2011, p. 04) esclarece que, através das relações de parceria travadas com o Estado, as entidades da sociedade civil perdem parte de sua liberdade de atuação em face de sujeições e obrigações de direito público necessárias à prevenção contra abusos de gestão, sem se tornarem, contudo, Estado, sem se transformarem em autarquias e sem assumirem também a defasagem estrutural entre o ritmo da sociedade e aquele do Estado.

${ }^{258} \mathrm{O}$ polo estatal da relação colaborativa continuará sujeito ao controle burocrático de meios pautado pela verificação do preenchimento das exigências legais, ainda que a perspectiva gerencial da Administração prescreva a busca constante por mecanismos flexíveis e consensuais de gestão administrativas, simplificando os procedimentos.

${ }^{259}$ Essa foi a conclusão a que chegou o Tribunal de Contas da União no Acórdão n ${ }^{\circ} 1.111 / 2008$, no qual ficou estabelecido que as OSs configuram pessoas jurídicas de natureza privada e, como tal, se sujeitam ao regime de direito privado, o qual resulta derrogado por princípios publicistas, contudo, justamente quando celebradas parcerias com o Estado para o recebimento de recursos públicos, controlando-se especialmente os aspectos orçamentário-financeiros e a qualidade dos serviços prestados. Nesse sentido, Paulo Eduardo Garrido $\operatorname{MODESTO}(2011$, p. 06) leciona que a aplicação do Direito Administrativo às entidades privadas que firmam voluntariamente vínculos de parceria e fomento com o Estado para o desenvolvimento de atividades essenciais à coletividade circunscreve-se a aspectos de proteção do bom emprego dos recursos públicos transferidos e aos próprios fins do fomento.
} 
Ademais, essas perspectivas formal e material do controle mesclam-se em todos os momentos do controle ${ }^{260}$ dos contratos de colaboração: na da celebração, durante a execução e quando da extinção do vínculo de parceria firmado.

O controle prévio, a priori ou ex ante é aquele que incide antes da celebração do contrato de colaboração, nomeadamente sobre o procedimento objetivo de seleção das entidades privadas, cabendo à Administração Pública analisar tanto a sua legalidade (preenchimento dos requisitos legais, pelos seus agentes administrativos e pelas organizações privadas concorrentes) ${ }^{261}$ quanto o seu mérito (conformidade com as diretrizes, programas ou planos de governo) $)^{262}$.

${ }^{260}$ Floriano de Azevedo MARQUES NETO (2010, p. 213) leciona que, quanto ao momento, o controle se subdivide em: (i) prévio, a priori ou ex ante: realizado antes da ação administrativa, a fim de evitar que o ato ilegal ou contrário aos interesses públicos seja praticado; (ii) concomitante: feito simultaneamente à prática do ato ou execução do procedimento administrativo; e (iii) posterior, a posteriori ou ex post: quando se analisa um ato ou procedimento que já esteja a produzir efeitos. O Autor adverte, entretanto, que, dum lado, a tempestividade (precipitação) do controle não pode implicar a antecipação da ingerência controladora ao momento prévio à prática do ato ou do procedimento de tal sorte que a atuação do controlador se confunda com a atuação do gestor; e, d'outro, o controle posterior não pressupõe que os efeitos sejam irreversíveis, de modo a se afastar a crítica recorrente de que o controle ex post se aproxima do trabalho do médico legista, que só é chamado para examinar a vítima, o morto, quando já defunta. Para o Professor, o efetivo controle pressupõe a separação entre a atividade controlada (realizada antes) e a atividade de controle (que deve se basear num ato ou procedimento já efetivados, sem o que o controle se imiscuirá na atividade administrativa, perdendo-se a fronteira entre a gestão e o controle). Data maxima venia, a crítica do Autor merece algum reparo: em primeiro lugar, ela se adéqua mais ao controle externo, não se mostrando pertinente quando se está em jogo o autocontrole/controle interno, exercido endogenamente pela Administração Pública, possuidora que é do poder de gestão/administração; em segundo lugar, ainda que se trate do controle externo, exercido por órgãos alheios à Administração Pública, é possível vislumbrar controle prévio dos atos e procedimentos administrativos, desde que se cuide, como o próprio Floriano de Azevedo MARQUES NETO (2010, p. 219-221) chama, do controle articulação, ao, opondo-se ao controle fiscalização (de monitoramento, verificação, de natureza predominantemente corretiva), destina-se a simplificar, integrar e unificar a ação administrativa, promovendo o compartilhamento de informações em rede, a racionalização no uso dos recursos e a unificação de procedimentos, evitando-se a sobreposição de competências e a duplicação de níveis decisórios. No âmbito dos contratos de colaboração, entendemos o controle prévio de articulação no sentido de uniformização da ação de fomento estatal, notadamente no que diz respeito às minúcias não previstas em lei ou atos normativos infralegais, evitando casuísmos, contribuindo para a segurança jurídica e evitando glosas pelos órgãos de controle externo. Exemplificativamente, é o que precisa ocorrer com os regulamentos de contratações a serem elaborados pela entidade privada parceira e aprovados pela Administração, os quais dependem de diretrizes mais claras que permitam a sua padronização.

${ }^{261}$ Os requisitos da celebração dos contratos de colaboração estão previstos na legislação que disciplina cada uma de suas espécies, existindo hoje, salvo quanto aos contratos de gestão com as OSs - excluídos do âmbito de incidência da Lei por força do inciso III do seu art. $3^{\circ}-$, certa uniformidade quanto ao procedimento de seleção das entidades de colaboração, nomeadamente porque a Lei Federal no 13.019/2014 disciplinou pormenorizadamente o já tratado chamamento público. Como bem colocado por Natasha Schimitt Caccia SALINAS (2008, p. 113-117), importante ferramenta de controle prévio do contrato de colaboração é a exigência de títulos jurídicos da entidade de colaboração, como é o caso da qualificação de OS e de OSCIP, necessárias que são, respectivamente, para a celebração de contrato de gestão e termo de parceria, dependendo do atendimento duma série de requisitos previstos na lei de regência, cuja verificação cabe à Administração Pública.

${ }^{262}$ Anote-se o entendimento fixado no Enunciado $\mathrm{n}^{\circ} 78$ da Súmula do TCU segundo o qual a seleção da entidade de colaboração e a assinatura do respectivo instrumento de parceria não estão condicionadas, como requisito de sua validade, à aprovação prévia do Tribunal de Contas, que não pode se substituir na função administrativa dos órgãos e entidades da Administração Pública. Isso não significa dizer, contudo, que o Tribunal de Contas não exerce qualquer forma de controle prévio dos contratos de colaboração, admitido, com 
A seu turno, o controle interno concomitante ou simultâneo é aquele ocorrido durante a execução do contrato de colaboração, já recaindo propriamente sobre a gestão de recursos públicos em curso pelo parceiro privado, reclamando que a sua em concordância com os princípios constitucionais de proteção ao patrimônio público ${ }^{263}$, bem como que os cronogramas de execução física (a cargo do parceiro privado) estejam em consonância com o cronograma de execução financeira (a cargo do órgão ou entidade pública repassadora) (Natasha Schmitt Caccia SALINAS, 2008, p. 138) ${ }^{264}$.

Finalmente, o controle posterior, a posteriori ou ex post é o empreendido após o encerramento do instrumento colaborativo, quando, por ocasião da prestação de contas final, verificar-se-á se os objetivos definidos no planejamento estatal e lançados no respectivo instrumento de parceria foram devidamente atendidos, levantando-se as irregularidades formais apontadas, corrigindo-se-as de modo concertado com o parceiro privado e, a depender da sua gravidade, sancionando-se as entidades de colaboração ${ }^{265}$. No plano normativo nacional, essa prestação de contas final vem pormenorizada na legislação que

esteio nas competências traçadas na sua Lei Orgânica (Lei Federal nº 8.443/1992), através do exercício da sua função consultiva (art. $\left.1^{\circ}, \mathrm{XVII}\right)$ e normativa (art. $3^{\circ}$ ).

${ }^{263}$ Segundo Natasha Schimitt Caccia SALINAS (2008, p. 132), ganha relevo neste ponto a necessária movimentação dos recursos em conta bancária específica. Destacamos, ainda, a exigência de procedimento objetivo simplificado para a contratação de terceiros e de pessoal pelas entidades de colaboração, em que se assegure a impessoalidade e a eficiência no gasto do dinheiro repassado.

${ }^{264}$ Trata-se da chamada prestação de contas parcial, tratada, por exemplo, no art. 48 da Lei Federal ${ }^{\circ}$ 13.019/2014, de acordo com o qual as parcelas dos recursos previstos na parceria serão liberadas na estrita conformidade com o cronograma de desembolso aprovado, exceto se verificadas impropriedades na execução do contrato, quando ficarão retidas até o seu saneamento. Os incisos deste dispositivo legal trazem as hipóteses em que se autoriza tal retenção, relacionadas ao cumprimento das etapas ou fases programadas (controle de resultados), à má aplicação dos recursos públicos repassados (controle de meios), além da não adoção das medidas saneadoras estipuladas (perspectiva consensual/didática do controle). Ademais, o art. 58 da Lei de Parcerias traz a figura do "relatório técnico de monitoramento e avaliação da parceria", a ser elaborado pela Administração Pública, independentemente da prestação de contas pela organização da sociedade civil parceira.

${ }^{265} \mathrm{O}$ art. 73 da Lei Federal no 13.019/2014 traz as sanções que a Administração poderá aplicar às entidades privadas parceiras que descumprirem o plano de trabalho ou qualquer disposição legal, sempre garantida, é claro, a defesa prévia da organização: (i) advertência; (ii) suspensão temporária, por prazo não superior a 02 (dois) anos, da participação em chamamento público e impedimento de celebrar termos de fomento, termos de colaboração e contratos em geral com a Administração da esfera de governo sancionadora; (iii) declaração de inidoneidade para participar de chamamento público ou celebrar termos de fomento, termos de colaboração e contratos em geral com a Administração de todas as esferas de governo, enquanto perdurarem os motivos determinantes da punição ou até que seja promovida a reabilitação perante a própria autoridade que aplicou a penalidade, que será concedida sempre que a organização da sociedade civil ressarcir a Administração pelos prejuízos resultantes, e após decorrido o prazo da sanção aplicada com base no item "ii". Registre-se também que o art. 77 e 78 da Lei modificou ainda a Lei de Improbidade Administrativa (Lei Federal no 8.429/1992), expressamente consignando entre as hipóteses de ato de improbidade violações relacionadas aos contratos de colaboração. Trata-se de modificação um tanto quanto desnecessária, na medida em que o par. único do art. $1^{\circ}$ da Lei de Improbidade sempre estendeu a sua aplicação às entidades privadas que recebessem qualquer espécie de subvenção, auxílio ou incentivo público, já podendo haver a responsabilização por quaisquer espécies de atos constantes dos arts. $9^{\circ}$ (caput e incisos XI, XII, entre outros), 10 (caput e incisos I, II, VI, VII, IX, XI, XII, XIV, entre outros) e 11 (caput e incisos I, VI, entre outros) da Lei de Improbidade. 
disciplina cada espécie de contrato de colaboração ${ }^{266}$, dependo a sua eficácia de investimentos na estruturação dos órgãos internos e externos de controle ${ }^{267}$ e da qualidade da fiscalização desenvolvida antes e durante a celebração do instrumento colaborativo ${ }^{268}$.

As prestações de contas parcial e final envolvem a avaliação da execução físicofinanceira do contrato de colaboração, mediante a apresentação de vários documentos, basicamente relacionados com a execução física e financeira do objeto da parceria, que, como visto, devem guardar compatibilidade entre si. Nesse trilhar, o art. 65 da Lei Federal $n^{\circ}$ 13.019/2014 estabelece que a prestação de contas far-se-á mediante a apresentação dos documentos exigidos no plano de trabalho, dos relatórios a cargo da organização privada parceira (de execução do objeto e de execução financeira) e dos relatórios internos elaborados pela própria Administração (de visita técnica in loco e técnico de monitoramento e avaliação).

Tratando um pouco do controle externo exercido pelo Tribunal de Contas, registrese que a prestação de contas pela entidade de colaboração deve ser feita à Administração Pública, não cabendo à Corte de Contas proceder à sua verificação diretamente. É a lição de Marcela Roza Leonardo ZEN (2008, p. 84), que observa a jurisprudência do TCU (Decisão n 931/1999) no sentido de que a prestação de contas deve ser encaminhada ao órgão público parceiro, e não ao Tribunal de Contas, sem prejuízo de que, no julgamento das contas anuais dos responsáveis no âmbito estatal pela celebração do contrato de colaboração ${ }^{269}$, essa Corte

\footnotetext{
${ }^{266}$ Convênios, contratos de repasse e instrumentos congêneres (arts. 72-76 da Portaria Interministerial $\mathrm{n}^{\circ}$ 507/2011 e art. 10, pars. $6^{\circ}-12$, do Decreto Federal n ${ }^{\circ}$ 6.170/2008); contratos de gestão (arts. $8^{\circ}-10$ da Lei Federal $\mathrm{n}^{\mathrm{o}}$ ); termos de parceria (); e termos de colaboração e de fomento (arts. 63-72 da Lei Federal $\mathrm{n}^{\circ}$ 13.019/2014).

${ }^{267}$ Janaina SCHOENMAKER (2011, p. 166) chama atenção para a debilidade estrutural do sistema de controle interno dos contratos de colaboração, colacionando relatório de 2006 editado pelo TCU em que se registra que as "prestações de contas se acumulam nos órgãos repassadores, carentes de pessoal e meios, em quantidade e qualidade, para analisá-las, Convenentes se omitem no dever de prestar contas. O atraso médio, em toda a administração pública federal, é de 3,9 anos na entrega de prestações de contas, e de 5,4 anos a idade média dos processos aguardando análise, perfazendo um montante de R \$ 12,5 bilhões em recursos, cuja aplicação o governo desconhece os resultados [...]". Assim também, Maria Sylvia Zanella DI PIETRO (2015, p. 312), que, comentando as medidas moralizadoras da recente Lei de Parcerias, observa que "seu cumprimento vai depender, em grande parte, da atuação eficiente dos órgãos de controle".

${ }^{268}$ Natasha Schmitt Caccia SALINAS (2008, p. 140) que a "ausência de controle anterior e concomitante torna, conforme o TCU insiste em frisar, praticamente inócua a fase de controle posterior", sendo comum, neste momento, "que os convenentes apresentem notas referentes a compras e serviços que não realizaram, mas que o órgão repassador jamais terá como se certificar, já que falhou no acompanhamento da execução do projeto". ${ }^{269} \mathrm{O}$ julgado do TCU se refere aos termos de parceria com as OSCIPs, mas as razões de decidir se aplicam perfeitamente a toda e qualquer espécie de contrato de colaboração. Assim também decidiu a Corte de Contas Federal no Acórdão $\mathrm{n}^{\circ}$ 4.522/2008, fixando-se que as organizações sociais não devem prestar contas diretamente ao TCU, tendo em vista que "os órgãos governamentais contratantes (supervisores) dessas entidades já devem, por disposição legal, supervisioná-las, acompanha-las e avaliá-las”. De acordo com Janaina SCHOENMAKER (2011, p. 179), "a majoritária doutrina compartilha deste entendimento".
} 
proceda à avaliação da celebração e execução desses instrumentos, nos termos do art. 71 da Constituição Federal c/c os arts. $1^{\circ}$, e $6^{\circ}$ a $9^{\circ}$, da Lei Federal n ${ }^{\circ} 8.443 / 1992^{270}$.

Registre-se também o controle dos contratos de colaboração realizado pelo Ministério Público, a quem incumbe, nos termos dos arts. 127, caput da Constituição Federal, a defesa da ordem jurídica e dos interesses sociais, especialmente através dos instrumentos constitucionais do inquérito civil e da ação civil pública, dirigidos à proteção do patrimônio público e social, do meio ambiente e de outros interesses difusos e coletivos (art. 129, II e III), com a possibilidade de requisitar informações e documentos (art. 26, I, “b”, e II, da Lei Federal no 8.625/1993, e art. 8, II e IV, da Lei Federal Complementar n 75/1993) e expedir recomendações (art. 6º, XX, da Lei Federal Complementar no 75/1993).

Ainda, o controle pelo Poder Judiciário, que pode sempre ser provocado para, de forma preventiva ou repressiva, tutelar qualquer lesão ou ameaça de direito (art. $5^{\circ}, \mathrm{XXXV}$, da Constituição), com destaque para as ações constitucionais do mandado de segurança (art. $5^{\circ}$, LXIX e LXX) e popular (art. $5^{\circ}$, LXXIII).

Por fim, destaque-se a importância que controle social da Administração Pública assumiu a partir da Constituição Federal de 1988 (Constituição Cidadã), através, por exemplo, de representações/denúncias individuais à Administração Pública (art. $5^{\circ}$, XXXIV, “a”), da ação popular (art. 5, LXXIII) e dos conselhos de políticas públicas. Estes últimos estão previstos em nosso ordenamento jurídico federal para os termos de parceria (arts. 10, $\S 1^{\text {o }}$, e 11, da Lei Federal no 9.790/1999, c/c o art. 10 do Decreto Federal no 3.100/1999) e para os recentes termos de colaboração e termos de fomento (arts. $2^{\circ}$, IX, 16, par. único, e 60, da Lei Federal $\mathrm{n}^{\mathrm{o}}$ 13.019/2014), possuindo função consultiva ${ }^{271}$ e de acompanhamento e

\footnotetext{
${ }^{270}$ Janaina SCHOENMAKER (2011, p. 171-185) esclarece os procedimentos de controle do TCU sobre as entidades de colaboração: (i) fiscalização: através de inspeções, auditorias, acompanhamentos e monitoramentos, praticada com fundamento no inciso IV do art. 71 da Constituição Federal; (ii) tomada de contas especial: procedimento administrativo de caráter excepcional que visa a apurar a responsabilidade por omissão ou irregularidade no dever de prestar contas ou por danos causados ao Erário, utilizado pelo TCU para julgar as contas das entidades de colaboração quando houver rejeição parcial ou total das contas apresentadas pelo gestor ao órgão repassador de recursos, irregularidades detectadas por ação dos órgãos fiscalizadores e denúncias de irregularidades nos instrumentos de parceria com as organizações da sociedade civil sem fins lucrativos recebedoras de recursos públicos; (iii) denúncia: podendo a entidade de colaboração tanto denunciar quanto ser denunciada à Corte de Contas; e (iv) consulta: somente se admitindo a consulta formulada por autoridade administrativa, não possuindo a entidade privada legitimidade para tanto - trata-se de verdadeira modalidade de controle externo prévio.

${ }^{271}$ Os termos de parceria têm a sua celebração condicionada à consulta prévia ao Conselho de Políticas Públicas da área objeto da parceria, não se admitindo que a sua ausência seja suprida por Conselho de outra área (art. $10, \S 2^{\circ}$, do Decreto). Como bem destaca Natasha Schimitt Caccia SALINAS (2008, p. 161), o parecer emitido pelo Conselho é meramente opinativo, não vinculando a Administração Pública, muito embora entenda o TCU (Decisão no 931/1999) que "a eventual não adoção da posição emanada do Conselho deveria ser justificada pelo órgão estatal parceiro". Diversamente, a recente Lei de Parcerias não prevê a consulta ao Conselho como
} 
fiscalização desses contratos de colaboração ${ }^{272}$. Registre-se também que o $§ 2^{\circ}$ do art. 58 da Lei Federal no 13.019/2014 prevê que a Administração deverá realizar "pesquisa de satisfação com os beneficiários do plano de trabalho" no caso de parcerias com vigência superior a 01 (um) ano.

condição prévia da celebração dos termos de colaboração e de fomento nela disciplinados, limitando-se a prever a sua função "consultiva, na respectiva área de atuação, na formulação, implementação, acompanhamento, monitoramento e avaliação das políticas públicas" (art. $2^{\circ}$, IV). Este diploma normativo inova, contudo, ao permitir que o Conselho da área proponha termo de colaboração com organizações da sociedade civil à Administração Pública.

272 Natasha Schmitt Caccia SALINAS (2008, p. 161) assinala, entretanto, que, no acompanhamento e fiscalização dos contratos de colaboração [na verdade, a Autora está tratando especificamente dos termos de parceria com as OSCIPs], não cabe aos Conselhos de Políticas Públicas introduzir ou induzir modificações nas obrigações estabelecidas no instrumento de parceria, limitando-se a expedir recomendações, razão pela qual os Conselhos não contribuiriam efetivamente para a formulação de políticas públicas, sendo o controle social operado por meio desta ferramenta meramente figurativo. 


\section{CONCLUSÃO}

1. Os contratos de colaboração são todos os instrumentos negociais de caráter continuado firmados entre o Poder Público e as organizações não estatais sem fins lucrativos para a prestação colaborada de serviços sociais.

2. O regime jurídico dos contratos de colaboração é determinado pela combinação duma série de fatores presentes nessas parcerias sociais entre os setores público e privado: (i) a natureza jurídica do instrumento; (ii) a natureza jurídica das partes; e (iii) a natureza jurídica do objeto;

3. A natureza contratual do instrumento define a competência constitucional legislativa para a disciplina do emparceiramento social do Estado com o terceiro setor, sendo da União, nos termos do inciso XXVII do art. 22 da Constituição, a atribuição para disciplinar essas espécies colaborativas de contratação administrativa;

4. A natureza de fomento administrativo do instrumento exige a observância dos princípios gerais que norteiam o funcionamento da Administração Pública, bem como aqueles específicos dessa atividade administrativa, em especial o princípio da repartição de riscos ou do risco compartido. Além disso, sendo os contratos de colaboração uma legítima ferramenta de fomento administrativo, os recursos transferidos pelo Estado ao parceiro privado mantêm-se como públicos, de modo que, embora passem à gestão privada da organização não estatal, sujeitam-se às normas jurídicas de proteção do patrimônio público;

5. A natureza das partes determina: dum lado, que o Poder Público observe as limitações exorbitantes que marcam o regime jurídico administrativo e paute a sua ação de fomento pela busca do atendimento das necessidades coletivas, assegurando o cumprimento dos objetivos sociais traçados; doutro, diante da presença de pessoas não estatais de direito privado sem fins lucrativos, a impossibilidade de se esvaziar a liberdade de criação, organização, funcionamento e extinção dessas entidades da sociedade civil, por um imperativo da autonomia privada e das garantias constitucionais da liberdade de associação e de auto-organização associativa; 
6. A natureza de serviço de relevância pública do seu objeto impõe ao Poder Público: uma tutela ostensiva da prestação dessas atividades, legitimando, para além do poder de polícia que recai sobre toda e qualquer ação dos particulares, a imposição legal de verdadeiras obrigações publicísticas para aqueles que pretendam executar serviços sociais; e um dever de garantia da boa prestação dos serviços, na medida em que é da essência do Estado, em sua perspectiva instrumental, assegurar a o atendimento das necessidades coletivas e a proteção dos direitos fundamentais;

7. Enquanto instrumento de fomento administrativo viabilizador da transferência de recursos públicos ao setor privado, o contrato de colaboração tem a sua celebração condicionada pelos princípios administrativos e de proteção do patrimônio público, razão pela qual a seleção das entidades de colaboração depende da realização de certame objetivo simplificado, que oportunize a todos os interessados o direito de disputar o emparceiramento com o Estado e que garanta a escolha do parceiro mais apto à concretização dos objetivos sociais visados;

8. O certame objetivo simplificado de seleção de entidades de colaboração não se confunde com o instituto da licitação pública, na medida em que este, tal como previsto no art. 37, XXI, da Constituição, dirige-se àqueles contratos pautados pela lógica retributiva/remuneratória, com garantia do equilíbrio econômicofinanceiro pelo Estado, mais afeta aos tradicionais contratos administrativos;

9. O regime de prestação de serviços sociais através do contrato de colaboração submete-se a um regime jurídico de Direito Privado derrogado por normas publicísticas: dum lado, impõem-se ao parceiro privado obrigações restritivas e compromissos coletivos decorrentes dos princípios constitucionais, de previsões legais expressas e do próprio instrumento colaborativo, sempre com vistas à realização dos interesses públicos e à proteção dos direitos fundamentais; doutro, não se admite o esvaziamento das liberdades de iniciativa e de associação dos particulares, sendo absolutamente indevida a submissão das entidades de colaboração ao regime jurídico administrativo estrito, não lhes podendo impor deveres de obrigatoriedade de ingresso ou de continuidade na prestação dos serviços; 
10. O emparceiramento com o Estado robustece o comprometimento dos prestadores privados de serviços sociais com os interesses públicos, na medida em que a Administração parceira do Estado condiciona a celebração do contrato de colaboração e a entrega de recursos públicos ao atingimento duma série de metas e objetivos sociais, direcionados à prestação universalizante e eficiente dessas utilidades coletivas pelo parceiro privado;

11. O regime dos bens geridos pelas entidades de colaboração interfere diretamente no regime de prestação dos seus serviços, devendo-se diferenciar três núcleos de bens: (i) bens titularizados pelo parceiro privado e não afetados à prestação dos serviços sociais: possuem natureza privada e, por conseguinte, são livremente alienáveis, penhoráveis e prescritíveis; (ii) bens titularizados pelo parceiro privado e afetados à prestação dos serviços sociais: possuem natureza privada, e, embora sejam alienáveis, penhoráveis e prescritíveis, qualquer constrição/limitação estará condicionada pela dignidade da pessoa humana dos usuários dos serviços; (iii) bens públicos transferidos à gestão dos parceiros privados: mantendo-se como públicos, são inalienáveis, impenhoráveis e imprescritíveis;

12. O regime de contratação de obras, serviços, compras, alienações e pessoal pelas entidades de colaboração deverá observar, no que tange aos recursos públicos repassados, os princípios que norteiam a gestão do patrimônio público: embora não se exija a realização de licitação pública, a contratação de terceiros deverá, salvo quanto ao pessoal (diretores, conselheiros e gerentes, empregados, temporários, autônomos, estagiários, voluntários, etc.), seguir um procedimento objetivo simplificado de seleção, que assegure especialmente os princípios administrativos da impessoalidade, transparência, eficiência e economicidade; a despeito de ser livre a escolha do pessoal das entidades de colaboração, a natureza pública das verbas transferidas pelo Estado impõe limites à remuneração dos seus serviços, bem como a transparência da sua contratação, devendo ser apresentada à Administração lista com a relação do pessoal contratado, funções desempenhadas e quaisquer valores pagos;

13. A responsabilidade civil extracontratual das entidades de colaboração pelos danos causados a terceiros na execução da parceria é do tipo subjetiva, na 
medida em que não integram o aparato estatal e não prestam serviços públicos, não incidindo a regra contida no $\S 6^{\circ}$ do art. 37 da Constituição Federal;

14. Por sua vez, não há que se falar, nem mesmo na modalidade subsidiária, em responsabilidade civil aquiliana do Estado pelos danos causados na prestação colaborada de serviços sociais, eis que as entidades de colaboração se localizam fora da estrutura da Administração, prestando, por direito próprio, serviços de relevância pública, sem qualquer instrumento de delegação estatal, caracterizando-se a ação do Estado como legítimo fomento administrativo;

15. Finalmente, a gestão privada de recursos públicos pelas entidades de colaboração sujeita a sua atuação aos mecanismos de controle interno e externo da Administração, em reconhecimento de que o Direito Administrativo não se limita à estrutura do Estado, alcançando toda e qualquer pessoa que manipule recursos públicos e desenvolva cometimentos de interesse coletivo;

16. Esse controle dos contratos de colaboração será realizado tanto numa perspectiva formal (de meios) quanto material (de resultados), que se somam para submeter a gestão privada de recursos públicos pelo parceiro privado tanto à análise dos procedimentos adotados quanto ao exame do atingimento das metas e objetivos sociais traçados;

17. O controle formal dos contratos de colaboração abrange, quanto ao parceiro estatal, a verificação da observância do regime jurídico administrativo, inclusive a partir do exame do mérito da ação de fomento público, aferindo-se a compatibilidade das parcerias entabuladas com os programas definidos pelo planejamento estatal; limitando-se, quanto ao parceiro não estatal, à gestão dos recursos públicos transferidos pela Administração, exigindo-se, no contexto do controle moderado ou flexibilizado de legalidade, tão somente o respeito aos princípios e valores de proteção ao patrimônio público;

18. O controle material dos contratos de colaboração, por sua vez, envolverá a conferência da consecução das metas e objetivos definidos na legislação de regência e no instrumento de parceria celebrado, tendo por referencial o plano de trabalho apresentado pelo parceiro privado e aprovado pela Administração Pública; 
19. O controle do contrato de colaboração se dará em todos os momentos da parceria, antes, durante e depois da execução do instrumento colaborativo, reclamando uma efetiva estruturação das instâncias administrativas de fiscalização; 


\section{REFERÊNCIAS}

AGUIAR, Ubiratan; MARTINS, Ana Claudia Messias de Lima; WIECHERS, Paulo Roberto; SILVA, Pedro Tadeu Oliveira da. Convênios e Tomadas de Contas Especiais. 3 ed. Belo Horizonte: Editora Fórum, 2008.

AGUILlaR, Fernando Herren. Serviços Públicos: Doutrina, Jurisprudência e Legislação. Coleção Direito Econômico, Coord. Fernando Herren Aguillar. São Paulo: Editora Saraiva, 2011.

ALMEIDA, Guilherme Henrique de La Rocque. Controle das Transferências Financeiras da União. Belo Horizonte: Editora Fórum, 2008.

ALVES, Francisco de Assis. Fundações, Organizações Sociais e Agências Executivas: organizações da sociedade civil de interesse público e outras modalidades de prestação de serviços públicos. São Paulo: Editora LTr, 2000.

ARAGÃO, Alexandre Santos de. Direito dos Serviços Públicos. $2^{\mathrm{a}}$ edição. Rio de Janeiro: Forense, 2008.

BACELLAR FILHO, Romeu Felipe. O Direito Administrativo e o Novo Código Civil. Belo Horizonte: Editora Fórum, 2007.

BARBOSA, Maria Nazaré Lins. A Experiência dos Termos de Parceria entre o Poder Público e as Organizações da Sociedade Civil de Interesse Público (OSCIPS). In: SUNDFELD, Carlos Ari. Parcerias Público Privadas. 2. Ed. São Paulo: Editora Malheiros, 2011, pp. 522-562.

BARROSO, Luís Roberto. Agências Reguladoras: Constituição, Transformações do Estado e Legitimidade Democrática. In: Uma Avaliação das Tendências Contemporâneas do Direito Administrativo. Diogo Figueiredo Moreira Neto (Coordenador). Rio de Janeiro: Renovar, 2003.

Agências Executivas, Agências Reguladoras e Organizações Sociais: natureza jurídica, características, distinções e atribuições destes novos entes. In: Boletim de Direito Administrativo. São Paulo: NDJ, n 11, p. 801-822, nov. 2000. 
BORGES, Alice Gonzalez. Serviços Sociais Autônomos - Natureza Jurídica. Revista Eletrônica de Direito do Estado (REDE), Salvador, Instituto Brasileiro de Direito Público, $\mathrm{n}^{\circ}$ 26, abril/maio/junho de 2011. Disponível em: www.direitodoestado.com.br. Acesso em:

BRASIL. Constituição Federal, de 05.10.1988. Atualizada com as Emendas Constitucionais promulgadas. Disponível em: <www.planalto.gov.br>. Acesso em: 16/05/2013. em: 21/05/2013.

Lei no 91, de 28/08/1935. Disponível em: <www.planalto.gov.br>. Acesso em: 02/06/2013.

Lei 4.320, de 17/03/1964. Disponível em: <www.planalto.gov.br>. Acesso

Lei no 8.246, de 22/10/1991. Disponível em: <www.planalto.gov.br〉. Acesso em: 23/07/2013.

Lei $\mathbf{n}^{\mathbf{0}}$ 8.958, de 20/12/1994. Disponível em: <www.planalto.gov.br>. Acesso em: 09/05/2013.

Lei $\mathbf{n}^{\mathbf{0}}$ 9.637, de 15/05/1998. Disponível em: <www.planalto.gov.br>. Acesso em: 30/05/2013.

Lei $\mathbf{n}^{0}$ 9.790, de 23/03/1999. Disponível em: <www.planalto.gov.br>. Acesso em: 06/05/2013.

. Lei Complementar $\mathbf{n}^{\mathbf{0}}$ 101, de 04/05/2000. Disponível em: <www.planalto.gov.br>. Acesso em: 08/09/2013.

Lei $\mathbf{n}^{0}$ 13.019, de 31/07/2014. Disponível em: 〈www.planalto.gov.br〉. Acesso em: 05/08/2014.

. Decreto Federal $\mathbf{n}^{\mathbf{0}}$ 93.872, de 23/12/1986. Disponível em: <www.planalto.gov.br>. Acesso em: 03/05/2013.

. Decreto Federal no 3.100, de 30/06/1999. Disponível em: <www.planalto.gov.br>. Acesso em: 13/09/2013. 
<www.planalto.gov.br>. Acesso em: 16/05/2013.

Instrução Normativa STN $\mathbf{n}^{0}$ 01, de 15/01/1997. Disponível em:

<www.convenios.gov.br>. Acesso em: 21/05/2013.

Portaria Interministerial MP/MF/CGU $\mathbf{n}^{\mathbf{0}}$ 507, de 24/11/2011.

Disponível em: 〈www.convenios.gov.br>. Acesso em: 07/06/2013.

. Ministério do Planejamento, Orçamento e Gestão. Manual para Usuários

de Entidades Privadas Sem Fins Lucrativos. Brasília, 2010. Disponível em: <www.convenios.gov.br>. Acesso em: 16/05/2013. em: 14/09/2014.

Senado Federal. Glossário. Disponível em: 〈www.senado.gov.br〉. Acesso

. Supremo Tribunal Federal. RE $\mathbf{n}^{\mathbf{0}}$ 119.256-9/SP. Primeira Turma, Relator Ministro Moreira Alves, DJ 29/05/1992. Disponível em: <www.stf.jus.br>. Acesso em: $11 / 02 / 2014$.

. Supremo Tribunal Federal. RE n⿳ 161.243-6/DF. Segunda Turma, Relator Ministro Carlos Velloso, DJ de 19.12.1997. Disponível em: <www.stf.jus.br>. Acesso em: 02/05/2014.

. Supremo Tribunal Federal. ADI no 319-QO/DF. Plenário, Relator Ministro Moreira Alves, DJ 05/03/1999. Disponível em: 〈www.stf.jus.br〉. Acesso em: 17/05/2014.

. Supremo Tribunal Federal. ADI no 770-0/MG. Plenário, Relator Ministro Ellen Gracie, DJ 20/09/2002. Disponível em: 〈www.stf.jus.br〉. Acesso em: 17/05/2014.

. Supremo Tribunal Federal. ADI no 1.717-6/DF. Relator Ministro Sydney Sanches, DJ 28/03/2003. Disponível em: <www.stf.jus.br〉. Acesso em: 04/03/2014.

. Supremo Tribunal Federal. ADI no 342-9/PR. Plenário, Relator Ministro Sidney Sanches, DJ 11/04/2003. Disponível em: <www.stf.jus.br>. Acesso em: 02/05/2014.

. Supremo Tribunal Federal. Emb. Div. no RE no 210.251-2/SP. Plenário, Relatora Ministra Ellen Gracie, DJ 28/11/2003. Disponível em: <www.stf.jus.br>. Acesso em: 02/05/2014. 
. Supremo Tribunal Federal. ADI no 3.026-4/DF. Plenário, Relator Ministro Eros Grau, DJ 29/09/2006. Disponível em: <www.stf.jus.br>. Acesso em: 07/06/2014.

. Supremo Tribunal Federal. ADI-MC no 1.935-5/DF. Plenário, Relator Ministro Ilmar Galvão, DJ 21/09/2007. Disponível em: <www.stf.jus.br>. Acesso em: $11 / 04 / 2014$.

. Supremo Tribunal Federal. ADI n⿳ 1.864-9/PR. Plenário, Relator Ministro Maurício Corrêa, DJ 02/05/2008. Disponível em: <www.stf.jus.br>. Acesso em: 23/06/2014.

. Supremo Tribunal Federal. ADC no 16/DF. Plenário, Relator Ministro Cezar Peluso, DJ 09/09/2011. Disponível em: <www.stf.jus.br>. Acesso em: 07/04/2014.

. Supremo Tribunal Federal. ADI no 1.923/DF. Plenário, Relator Ministro Ayres Britto, pendente de julgamento. Disponível em: <www.stf.jus.br〉. Acesso em: 02/05/2014.

. Supremo Tribunal Federal. Voto de Relatoria do Ministro Relator Ayres $\begin{array}{llll}\text { Britto na } & \text { ADI } & \text { n }^{\circ} & 1.923 / D F \text {. }\end{array}$ <www.stf.jus.br/arquivo/cms/noticiaNoticiaStf/anexo/Voto_rel_1923.pdf>. Acesso em: $13 / 03 / 2014$.

. Supremo Tribunal Federal. Voto-Vista do Ministro Luiz FUX na ADI no 1.923/DF. Disponível em: <www.stf.jus.br/arquivo/cms/noticiaNoticiaStf/anexo/Voto__ADI1923LF.pdf>. Acesso em $16 / 07 / 2014$.

Superior Tribunal de Justiça. CComp no 41.246/SC. Primeira Seção, Relator Ministro Castro Meira, DJ 27/09/2004. Disponível em: <www.stj.jus.br>. Acesso em: 02/05/2014.

Disponível

. Tribunal de Contas da União. O TCU e as Entidades do Sistema "S". <www.camara.gov.br/internet/comissao/index/mista/orca/apresentacao/2013/RAP_Sistema S_25-06-2013.pdf>. Acesso em: 13/06/2014.

Tribunal de Contas da União. Decisão no 278, de 22/05/1996. Plenário, Relator Ministro Iram Saraiva. Brasília/DF. Disponível em: <www.tcu.gov.br>. Acesso em: 10/05/2014. 
Tribunal de Contas da União. Decisão no 907, de 11/12/1997. Plenário, Relator Ministro Lincoln Magalhães da Rocha. Brasília/DF, DOU 26/12/1997. Disponível em: 〈www.tcu.gov.br>. Acesso em: 12/05/2014.

Tribunal de Contas da União. Acórdão no 235, de 19/03/2003. Plenário, Ministro Relator Ubiratan Aguiar. Brasília/DF, DOU 28/03/2003. Disponível em: <www.tcu.gov.br>. Acesso em: 13/05/2014.

. Tribunal de Contas da União. Acórdão no 2.640, de 28/09/2011. Plenário, Relator Ministro Augusto Nardes. Brasília/DF. Disponível em: <www.tcu.gov.br〉. Acesso em: 09/03/2014.

. Tribunal de Contas da União. Acórdão no 1.111, de 11/06/2008. Plenário, Relator Ministro Augusto Sherman. Brasília, DOU 13/06/2008. Disponível em: <www.tcu.gov.br>. Acesso em: 17/06/2014.

. Tribunal de Contas da União. Acórdão no 1.077, de 09/07/2008. Plenário, Relator Ministro Benjamin Zynker. Disponível em: <www.tcu.gov.br>. Acesso em: 06/03/2014.

. Tribunal de Contas da União. Acórdão no 2.522, de 19/05/2009. 2ª Câmara, Relator Ministro Raimundo Carreiro. Brasília/DF. Disponível em: 〈www.tcu.gov.br>. Acesso em: 12/05/2014.

. Tribunal de Contas da União. Acórdão no 6.483, de 10/11/2009, $1^{\text {a }}$ Câmara, Ministro Relator Weder de Oliveira. Disponível em: <www.tcu.gov.br>. Acesso em: 12/05/2014.

BORGES, Alice Gonzalez. Serviços Sociais Autônomos - Natureza Jurídica. In: Revista Eletrônica de Direito do Estado - REDE, Salvador, Instituto Brasileiro de Direito Público, n. 26, abril/maio/junho, 2011. Disponível em: 〈www.direitodoestado.com.br〉. Acesso em: $15 / 05 / 2014$.

BRESSER PEREIRA, Luiz Carlos. Da Administração Pública Burocrática à Gerencial. In: Revista do Serviço Público, $\mathrm{n}^{\circ}$ 47(1), jan.-abr., 1996. Disponível em: <www.bresserpereira.org.br>. Acesso em: 13/09/2013.

BRESSER PEREIRA, Luiz Carlos; GRAU, Nuria Cunill. Entre o Estado e o Mercado: O Público Não-Estatal. In: BRESSER PEREIRA, Luiz Carlos; GRAU, Nuria Cunill (orgs.). O Público Não-Estatal na Reforma do Estado. Rio de Janeiro: Editora FGV, 1999, p. 15-48. 
CANOTILHO, José Joaquim Gomes. Direito Constitucional e Teoria da Constituição. 7. ed. Coimbra: Almedina, 2003.

CARNEIRO NETO, Durval. Os conselhos de fiscalização profissional: uma trajetória em busca de sua identidade jurídica. In: MODESTO, Paulo (Coord.), Nova organização administrativa brasileira. 2. ed. rev. e ampl. Belo Horizonte: Editora Fórum, 2010, p. 275320 .

CARVAlHO FILHO, José dos Santos. Manual de Direito Administrativo. 26 ed., rev., ampl. e atual. São Paulo: Editora Atlas, 2013.

CASSAGNE, Juan Carlos. La Intervenciòn Administrativa. Buenos Aires: AbeledoPerrot. 1992. 222p.

CASTRO, Rodrigo Pironti Aguirre de. O Sistema de Controle Interno e as Entidades do Terceiro Setor: Perspectiva Gerencial e o Princípio da Eficiência. In: OLIVEIRA, Gustavo Justino de (Coord.) Direito do Terceiro Setor. Belo Horizonte: Fórum, 2008. p. 163-176.

CUNNIL GRAU, Nuria. A Rearticulação das Relações Estado-sociedade: em busca de novos significados; In: Revista do Serviço Público. Ano 47, vol. 120, n. 1, jan-abr.

DALLARI, Adilson Abreu. Privatização, Eficiência e Responsabilidade. In: Uma Avaliação das Tendências Contemporâneas do Direito Administrativo. Diogo Figueiredo Moreira Neto (Coordenador). Rio de Janeiro: Renovar, 2003.

DIAS, Maria Tereza Fonseca. Terceiro Setor e Estado: Legitimidade e Regulação. Por um novo marco jurídico. Belo Horizonte. Editora Fórum, 2008.

DI PIETRO, Maria Sylvia Zanella; RAMOS, Dora Maria de Oliveira; SANTOS, Márcia Valquíria Batista do; D’ÁVILA, Vera Lúcia Machado. Temas Polêmicos sobre Licitações e Contratos. 5. ed. São Paulo: Malheiros, 2005.

DI PIETRO, Maria Sylvia Zanella. Privatização e o Novo Exercício de Funções Públicas por Particulares. In: MOREIRA NETO, Diogo de Figueiredo (Coord.). Uma Avaliação das Tendências Contemporâneas do Direito Administrativo. Rio de Janeiro: Renovar, 2003, p. 427-439. 
Das entidades paraestatais e das entidades de colaboração. In: MODESTO, Paulo (Coord.) Nova Organização Administrativa Brasileira. Belo Horizonte: Fórum, 2010a, p. 239-256.

. Responsabilidade Civil das Entidades Paraestatais. In: GUERRA, Alexandre Dartanhan de Mello; PIRES, Luiz Manuel Fonseca; BENACCHIO, Marcelo (Coord.). Responsabilidade Civil do Estado: Desafios Contemporâneos. São Paulo: Editora Quartier Latin do Brasil, 2010b, p. 823-842.

. Direito Administrativo. São Paulo: Atlas, 25ª edição, 2012.

. Parcerias na Administração Pública: Concessão, Permissão, Franquia, Terceirização, Parceria Público Privada e outras Formas. $8^{a}$ edição. São Paulo: Atlas, 2015.

DI PIETRO, Maria Sylvia Zanella; RIBEIRO, Carlos Vinicius Alves (Coord.). Supremacia do Interesse Público e Outros Temas Relevantes do Direito Administrativo. São Paulo: Atlas, 2010c.

DROMI, José Roberto. Reforma del Estado y Privatizaciones. Buenos Aires: Editora Astrea de A. y R. Depalma, 1991.

FERRAZ JUNIOR, Tercio Sampaio. Introdução ao Estudo do Direito: Técnica, Decisão e Dominação. $6^{\text {a }}$ edição. São Paulo: Atlas, 2008.

FERREIRA FILHO, Manoel Gonçalves. Reforma do Estado - o papel das agências reguladoras e fiscalizadoras. In: Revista Fórum Administrativo - FA, ano $1, \mathrm{n}^{\circ} 3$, maio, 2001, p. 253-257. Belo Horizonte: Editora Fórum, 2001.

FILHO, Marçal Justen. Curso de Direito Administrativo. São Paulo: Malheiros Editores, 2005.

FINANCIADORA DE ESTUDOS E PROJETOS - FINEP. Manual de Convênios e Termos de Cooperação. 2010. Disponível em: <www.finep.gov.br>. Acesso em: 06/02/2014.

GALDINO, Flávio. Introdução à Teoria dos Custos dos Direitos: Direitos Não Nascem em Árvores. Rio de Janeiro: Editora Lumen Juris, 2005. 
GUIMARÃES, Fernando Vernalha. A Teoria das Atividades Indelegáveis: Enquadramento do Tema na Atualidade. In: Revista de Direito Público da Economia RDPE. n. 42, abr./jun. 2013. Belo Horizonte: Editora Fórum.

GRAEF, Aldino; SALGADO, Valéria (Autores). ANTERO, Samuel A. (Org.). Fundação Instituto para o Fortalecimento das Capacidades Institucionais - IFCI / Agência Espanhola de Cooperação Internacional para o Desenvolvimento - AECID / Ministério do Planejamento, Orçamento e Gestão - MPOG. Relações de Parceria entre o Poder Público e Entes de Cooperação e Colaboração no Brasil. Brasília: Editora IABS, 2012.

GRAU, Eros. Conceito de "Relevância Pública" na Constituição de 1988. In: DALLARI, Suely Gandolfi (Org.). O conceito constitucional de relevância pública. Brasília: Editora Organização Panamericana da Saúde, p. 1992.

A Ordem Econômica na Constituição de 1988. 16 ${ }^{\text {a }}$ ed., rev. e atual. São Paulo: Editora Malheiros, 2014.

GROTTI, Dinorá Adelaide Musetti. O Serviço Público e a Constituição Brasileira de 1998. São Paulo: Editora Malheiros, 2003.

Parcerias na Administração Pública. In: Revista do Terceiro Setor RDTS. Ano 6, n 11, jan/jun, 2012. Belo Horizonte: Editora Fórum.

HIGA, Alberto Shinji. Terceiro Setor: Da Responsabilidade Civil do Estado e do Agente Fomentado. Belo Horizonte: Editora Fórum, 2010.

O Modelo das Organizações Sociais. In: Revista de Direito do Terceiro Setor-RDTS, ano 6, n. 11, janeiro/junho, 2012. Belo Horizonte: Editora Fórum, p.215-254.

INSTITUTO BRASILEIRO DE GEOGRAFIA E ESTATÍSTICA - IBGE. As Fundações Privadas e Associações sem Fins Lucrativos no Brasil 2005. Estudos e Pesquisas Informação Econômica $n^{\circ}$ 8. Diretoria de Pesquisas e Gerência do Cadastro Central de Empresas. Rio de Janeiro: $2008 . \quad$ Disponível em: <http://www.ibge.gov.br/home/estatistica/economia/fasfil/2005/fasfil.pdf >.

INSTITUTO CHICO MENDES DE CONSERVAÇÃO DA BIODIVERSIDADE ICMBIO. Manual de Convênios, Contratos de Repasse, Termos de Cooperação, Termos de Parceria e Termos de Reciprocidade. Portaria ICMBio n 37/2009. Disponível em: 〈www.icmbio.gov.br>. Acesso em: 09/01/2014>. 
INSTITUTO PRO BONO. Estatuto Jurídico do Terceiro Setor: pertinência, conteúdo e possibilidades de configuração normativa. In: Secretaria de Assuntos Legislativos do Ministério da Justiça (SAL), Série Pensando o Direito, no 16, Ano 2009a. Disponível em: <www.secretariageral.gov.br>. Acesso em: 03/02/2014.

. Estado Democrático de Direito e Terceiro Setor. In: Secretaria de Assuntos Legislativos do Ministério da Justiça (SAL), Série Pensando o Direito. 2009b. Disponível em: 〈www.secretariageral.gov.br>. Acesso em: 22/03/2014.

JORDANA DE POZAS, Luis. Ensayo de una Teoría de Fomento en el Derecho Administrativo. In: Revista de Estúdios Políticos, nº 48, nov/dez, 1949, p. 41-54. Disponível em <www.cepc.es>. Acesso em 13/04/2014.

JUSTEN, Monica Spezia. A Noção de Serviço Público no Direito Europeu. São Paulo: Editora Dialética, 2003.

JUSTEN FILHO, Marçal. O Direito das Agências Reguladoras Independentes. São Paulo: Editora Dialética, 2002.

Parecer Elaborado sobre a Proposta Legislativa de Criação de Consórcios Públicos. Revista Eletrônica de Direito do Estado. Salvador, Instituto de Direito Público da Bahia, $\mathrm{n}^{\circ}$ 3, julho/agosto/setembro. Disponível na internet em: <www.direitodoestado.com.br>. Acesso em: 23/08/2013.

Curso de Direito Administrativo. $9^{a}$ ed., rev., atual. e ampl. São Paulo: Editora Revista dos Tribunais, 2013.

LIMA, Carolina Caiado. O Convênio Administrativo Colaborativo para Transferência de Recursos Públicos a Entidades Privadas sem Fins Lucrativos como Instrumento dos Mecanismos Diretos de Fomento Público. 2010. 168f. Dissertação (Mestrado em Direito do Estado) - Faculdade de Direito, Universidade de São Paulo. São Paulo, 2010.

MAgalhães, Gustavo Alexandre. Convênios Administrativos: Aspectos Polêmicos e Análise Crítica de seu Regime Jurídico. São Paulo: Editora Atlas, 2012.

MÂNICA, Fernando Borges. Participação Privada na Prestação de Serviços Públicos de Saúde. 2009. 306f. Tese (Doutorado em Direito Administrativo) - Faculdade de Direito, Universidade de São Paulo, São Paulo, 2009. 
MÂNICA, Fernando Borges; MENEGAT, Fernando. A Natureza Jurídica do Contrato de Gestão com as Organizações Sociais e suas Repercussões no Sistema de Controle pelo Tribunal de Contas. In: Revista de Contratos Públicos. n. 3, mar./ago., 2013. Belo Horizonte: Editora Fórum, 2013, p. 47-72.

MARCHI, Eduardo C. Silveira. Guia de Metodologia Jurídica. $2^{a}$ edição. São Paulo: Saraiva, 2009.

MARQUES NETO, Floriano de Azevedo. Público e Privado no Setor de Saúde. Revista de Direito Público da Economia - RDPE. Belo Horizonte, ano 3, n. 9, p. 105-154, jan./mar. 2005.

Os Grandes Desafios do Controle da Administração Pública. In: MODESTO, Paulo (Coord.). Nova Administração Brasileira. 2ed. rev. e ampl. Belo Horizonte: Fórum, 2010, p. 199-238.

A Nova Regulamentação dos Serviços Públicos. Revista Eletrônica de Direito Administrativo Econômico. Salvador, Instituto de Direito Público da Bahia, $\mathrm{n}^{\circ} 1$, fevereiro, 2005. Disponível em: <www.direitodoestado.com.br〉. Acesso em: 15 de junho de 2012.

MARQUES NETO, Floriano de Azevedo; ALMEIDA, Fernando Dias Menezes de; NOHARA, Irene Patrícia; MARRARA, Thiago (Orgs.). Direito e Administração Pública: Estudos em Homenagem a Maria Sylvia Zanella Di Pietro. São Paulo: Editora Atlas, 2013.

MARTINS, Sérgio Pinto. A Terceirização e o Direito do Trabalho. $8^{a}$ ed. São Paulo: Editora Atlas, 2007.

MARTINS, Carlos Estevam. Governabilidade e Controles. Revista São Paulo em Perspectiva, v. 2(1): 10-17, jan./mar. 1988. Disponível em: <www.seade.gov.br>. Acesso: 12/08/2014.

MARTINS, Humberto Falcão. Gestão de Recursos Públicos: Orientação para Resultados e Accountability. Revista Eletrônica sobre a Reforma do Estado. Salvador, Instituto de Direito Público a Bahia, n. 3, setembro/outubro/novembro, 2005. Disponível na internet em: <www.direitodoestado.com.br>. Acesso em: 26/03/2014.

MEDAUAR, Odete. Controle da Administração Pública. $2^{\mathrm{a}}$ ed., rev., atual. e amp.. São Paulo: Editora Revista dos Tribunais, 2012. 
Direito Administrativo em Evolução. 2a ed., rev., atual. e ampl. São Paulo: Editora Revista dos Tribunais, 2003.

Direito Administrativo Moderno. $11^{a}$ ed., rev. e atual. São Paulo: Editora Revista dos Tribunais, 2007.

Serviços Públicos e Serviços de Interesse Econômico Geral. In: MOREIRA NETO, Diogo Figueiredo. Uma Avaliação das Tendências Contemporâneas do Direito Administrativo. $1^{\text {a }}$ edição. Rio de Janeiro: Renovar, 2003.

MEIRELLES, Hely Lopes. Direito Administrativo Brasileiro. São Paulo: Malheiros Editores, $35^{\text {a }}$ edição, 2009

MELlo, Celso Antônio Bandeira de. Curso de Direito Administrativo. São Paulo: Malheiros, 26ª edição, 2009.

. Serviço Público e Atividade Econômica: Serviço Postal. In: MELLO, Celso Antônio Bandeira de. Grandes Temas de Direito Administrativo. São Paulo: Editora Malheiros: $1^{\mathrm{a}}$ edição, $2^{\mathrm{a}}$ tiragem, 2010a, p. 301-314.

. Serviço Público e sua Feição Constitucional no Brasil. In: MELLO, Celso Antônio Bandeira de. Grandes Temas de Direito Administrativo. São Paulo: Editora Malheiros: $1^{a}$ edição, $2^{a}$ tiragem, 2010b, p. 270-288.

Editora Malheiros, 2010c.

Grandes Temas de Direito Administrativo. $1^{\mathrm{a}}$ ed., $2^{\mathrm{a}}$ tir. São Paulo:

MENEZES DE ALMEIDA, Fernando Dias. Contrato Administrativo. São Paulo: Editora Quartier Latin, 2012.

MODÉ, Fernando Magalhães. Endowment: os Fundos Patrimoniais e o Investimento Social no Brasil. In: OLIVEIRA, Gustavo Justino de (Coord.). Direito do Terceiro Setor. Belo Horizonte: Editora Fórum, 2008. p. 221-229.

MODESTO, Paulo Eduardo Garrido. Reforma Administrativa e Marco Legal das Organizações Sociais no Brasil - As Dúvidas dos Juristas sobre o Modelo das Organizações Sociais. In: Revista Diálogo Jurídico, Salvador, CAJ - Centro de Atualização Jurídica, v. I, nº. 9, dezembro, 2001. Disponível em: <www.direitopublico.com.br>. Acesso em: 11 de setembro de 2014 . 
Reforma do Estado, formas de prestação do serviço ao público e parcerias público-privadas: demarcando as fronteiras do conceito de serviço públicos, de relevância pública e serviços de exploração econômica para as parcerias públicoprivadas. In: Revista Eletrônica de Direito Administrativo Econômico, Salvador, Instituto de Direito Público da Bahia, $\mathrm{n}^{\circ}$ 2, maio-jun-jul, 2005. Disponível em: <www.direitodoestado.com.br>. Acesso em: 05/09/2013.

Reforma do Marco Legal do Terceiro Setor no Brasil. In: Revista Eletrônica de Direito do Estado - RERE, Salvador, Instituto de Direito Público da Bahia, ${ }^{\circ}$ 5, 2006. Disponível em: <www.direitodoestado.com.br>. Acesso em: 03/02/2014.

. O Direito Administrativo do Terceiro Setor: A Aplicação do Direito Público às Entidades Privadas Sem Fins Lucrativos. In: Revista Eletrônica sobre a Reforma do Estado - RERE, Salvador, Instituto Brasileiro de Direito Público, $\mathrm{n}^{\circ} 25$, março, abril, maio, 2011. Disponível em: <www.direitodoestado.com.br>. Acesso em: 15 de março de 2013.

MODESTO, Paulo (Coord.). Nova organização administrativa brasileira. $2^{\mathrm{a}}$ ed., rev. e ampl. Belo Horizonte: Editora Fórum, 2010.

MOREIRA NETO, Diogo de Figueiredo. Mutações no Direito Público. Rio de Janeiro: Editora Renovar, 2006.

Natureza Jurídica dos Serviços Sociais Autônomos. In: Revista de Direito Administrativo n. 207, 79-94. Rio de Janeiro: Editora Renovar, 2003.

. Novos Institutos Consensuais da Ação Administrativa. In: Revista de Direito Administrativo, n. 231, jan./mar. Rio de Janeiro: Editora Renovar, 2003.

Mutações nos Serviços Públicos. Revista Eletrônica de Direito Administrativo Econômico, Salvador, Instituto de Direito Público da Bahia, $n^{\circ}$ 1, fevereiro, 2005. Disponível em: <www.direitodoestado.com.br>. Acesso em: 18 de junho de 2012.

Quatro Paradigmas do Direito Administrativo Pós-Moderno: Legitimidade: Finalidade: Eficiência: Resultados. Belo Horizonte: Editora Fórum, 2008.

. Curso de Direito Administrativo: Parte Introdutória, Parte Geral e

Parte Especial. 16 ${ }^{\mathrm{a}}$ ed., rev. e atual. Rio de Janeiro: Editora Forense, 2014. 
MOREIRA NETO, Diogo de Figueiredo (Coord.). Uma Avaliação das Tendências Contemporâneas do Direito Administrativo. Rio de Janeiro: Editora Renovar, 2003.

MOREIRA, Vital. Auto-Regulação Profissional e Administração Pública. Coimbra: Editora Almedina, 1997.

Administração Autónoma e Associações Públicas. Reimpressão. Coimbra: Editora Coimbra, 2003.

. Os Serviços Públicos Tradicionais sob o Impacto da União Europeia. In: Revista de Direito Público da Economia. Belo Horizonte: Editora Fórum, n¹, p. $227-$ 279, jan./fev./mar., 2003.

OLIVEIRA, Regis Fernandes. Curso de Direito Financeiro. $6^{a}$ ed., rev., atual. e ampl. São Paulo: Editora Revista dos Tribunais, 2014.

OLIVEIRA, Gustavo Justino de. Constitucionalidade da Lei Federal $\mathbf{n}^{\circ}$ 9.637/98, das Organizações Sociais. In: Revista do Terceiro Setor - RDTS. Ano 1, n 2, jul./dez. 2007. Belo Horizonte: Editora Fórum, 2007a.

. Direito do Terceiro Setor. In: Revista do Terceiro Setor - RDTS. Ano 1, $\mathrm{n}^{\circ}$ 1, jan/jun 2007. Belo Horizonte: Editora Fórum, 2007b.

. Gestão Privada de Recursos Públicos para Fins Públicos: O Modelo das OSCIP. In: OLIVEIRA, Gustavo Justino de (Coord.). Terceiro Setor, Empresas e Estado: novas fronteiras entre o público e o privado. Belo Horizonte: Editora Fórum, 2007c, p. 213259.

. As Organizações sociais e o Supremo Tribunal Federal: comentários à Medida Cautelar da ADIn no 1.923-DF. In: OLIVEIRA, Gustavo Justino de (Coord.). Direito do Terceiro Setor. Belo Horizonte: Editora Fórum, 2008a, p. 13-36.

. Contrato de Gestão. São Paulo: Editora Revista dos Tribunais, 2008b.

OSCIPs e Licitação: Ilegalidade do Decreto $n^{0}$ 5.504, de 05.08.05. Revista Eletrônica sobre a Reforma do Estado (RERE). Salvador, Instituto Brasileiro de Direito Público, n. 12, dezembro/janeiro/fevereiro, 2008c. Disponível em: <www.direitodoestado.com.br>. Acesso em: 24/04/2014. 
OLIVEIRA, Gustavo Justino de (Coord.). Terceiro Setor, Empresas e Estado: Novas Fronteiras entre o Público e o Privado. Belo Horizonte: Editora Fórum, 2007.

. Direito do Terceiro Setor. Belo Horizonte: Editora Fórum, 2008.

OLIVEIRA, Gustavo Justino de; MÂNICA, Fernando Borges. Organizações da Sociedade Civil de Interesse Público: Termo de Parceria e Licitação. In: Boletim de Direito Administrativo. São Paulo, ano XXI, nº 9, p. 1010-1025, set. 2005. Disponível na internet em: <www.fernandomanica.com.br>. Acesso em: 23/04/2014.

OLIVEIRA, José Roberto Pimenta. Os Princípios da Razoabilidade e da Proporcionalidade no Direito Administrativo Brasileiro. São Paulo: Editora Malheiros, 2006.

ORTIZ, Gaspar Ariño. Economia y Estado: Crisis y Reforma del Sector Publico. Madrid: Editora Marcial Pons, 1993.

PAES, José Eduardo Sabo. Terceiro Setor: Conceituação e Observância dos Princípios Constitucionais Aplicáveis à Administração Pública. In: Fórum administrativo - Direito Público, Belo Horizonte, a. 5, no 48, p. 5093-5098, fev. 2005.

Fundações, Associações e Entidades de Interesse Social: Aspectos Jurídicos, Administrativos, Contábeis, Trabalhistas e Tributários. $8^{\mathrm{a}}$ ed., ver. e ampl. Rio de Janeiro: Editora Forense, 2013.

PELLEGRINI, Márcia. Terceiro Setor: Gestão Privada de Recursos Públicos. In: Revista do Terceiro Setor - RDTS, ano 1, n. 2, jul./dez. 2007. Belo Horizonte: Editora Fórum, 2007.

PEREIRA, João Gabriel Gomes. Inovações no Regime de Convênios, Contratos de Repasse e Termos de Parceria. In: Revista de Direito do Terceiro Setor - RDTS, ano 5, $\mathrm{n}$. 10, jul./dez., 2011. Belo Horizonte: Fórum, 2011. Disponível em: <www.oabsp.org.br.>. Acesso em: 03/05/2014.

PEREIRA, Luiz Carlos Bresser; GRAU, Nuria Cunill (Org.) O Público Não-estatal na Reforma do Estado. 1. Ed. São Paulo: FGV, 1999.

PEREIRA, Luiz Carlos Bresser (Coord.). Reforma do Estado e Administração Pública Gerencial. $7^{\mathrm{a}}$ ed. São Paulo: Editora FGV, 2006. 
PLATAFORMA POR UM NOVO MARCO REGULATÓRIO PARA AS ORGANIZAÇÕES DA SOCIEDADE CIVIL. Primeira Contribuição da Plataforma das OSCs para o Processo de Regulamentação da Lei $n^{\circ}$ 13.019/2014. 2014. Disponível em: <www.observatoriosc.files.wordpress.com/2014/09/proposta_regulamentac3a7c3a3o_lei13 019_plataformamrosc_final.pdf>. Acesso em: 15/10/2014.

PINTO, Bilac (Atual. Alexandre Santos de Aragão). A Regulamentação Efetiva dos Serviços de Utilidade Pública. $2^{a}$ ed. Rio de Janeiro: Editora Forense, 2002.

PINTO, Bruno Luís Amorim Pinto. Gestão Privada de Serviços Públicos por Organizações Sociais: Eficiência e Responsabilidade. In: DI PIETRO, Maria Sylvia Zanella. Direito Privado Administrativo. São Paulo: Editora Atlas, 2013, p. 148-167.

QUIRÓS, Mario Mora. Responsabilização pelo Controle de Resultados. In: BRESSERPEREIRA, Luiz Carlos; GRAU, Nuria Cunill (Coord.). Responsabilização na Administração Pública: Coletânea. São Paulo: Editora CLAD/Fundap, 2006.

QUIVY, Raymond; CAMPENHOUDT, Luc Van. (Tradução por MARQUES, João Minhoto; MENDES, Maria Amália; CARVALHO, Maria). Manual de Investigação em Ciências Sociais. 5a ed. Lisboa: Editora Gradiva, 2008.

REBOLLO, Luis Martin. Servicios Públicos e Servicios de Interés General: La nueva concepcion y operatividad del servicio público en el Derecho Administrativo Español. In: Uma Avaliação das Tendências Contemporâneas do Direito Administrativo. Rio de Janeiro: Renovar, 2003.

ROCHA, Silvio Luís Ferreira da. Terceiro Setor. $2^{\mathrm{a}}$ ed., rev. e aum. São Paulo: Editora Malheiros, 2006.

ROTHENBURG, Walter Claudius. Algumas Considerações sobre a Incidência de Direitos Fundamentais nas Relações do Estado com Empresas e Organizações Sociais. In: OLIVEIRA, Gustavo Justino de (Coord.). Terceiro Setor, Empresas e Estado: novas fronteiras entre o público e o privado. Belo Horizonte: Editora Fórum, 2007, p. 87-109.

SALINAS, Natasha Schmitt Caccia. Avaliação Legislativa no Brasil: Um Estudo de Caso sobre as Normas de Controle das Transferências Voluntárias de Recursos Públicos para Entidades do Terceiro Setor. 2008. 247f. Dissertação (Mestrado em Direito do Estado) Faculdade de Direito, Universidade de São Paulo. São Paulo, 2008. 
SANTOS, Boaventura Souza. A Reinvenção Solidária e Participativa do Estado. In: Seminário Internacional Sociedade e Reforma do Estado. São Paulo, mar./1998.

SCAFF, Fernando Facury. Contrato de Gestão, Serviços Sociais Autônomos e Intervenção do Estado. In: Revista de Direito Administrativo, Volume 225, jul./set. 2001, p. 273-297. Rio de Janeiro: Editora Renovar.

SCHIRATO, Vitor Rhein. Livre Iniciativa nos Serviços Públicos. Belo Horizonte: Editora Fórum, 2012.

SCHOENMAKER, Janaina. Controle das Parcerias entre o Estado e o Terceiro Setor pelos Tribunais de Contas. Belo Horizonte: Editora Fórum, 2011.

SILVA, Almiro do Couto e. Os Indivíduos e o Estado na Realização de Tarefas Públicas. In: MARQUES NETO, Floriano de Azevedo; ALMEIDA, Fernando Dias Menezes de; NOHARA, Irene Patrícia; MARRARA, Thiago (Orgs.). Direito e Administração Pública: Estudos em Homenagem a Maria Sylvia Zanella Di Pietro. São Paulo: Editora Atlas, 2013, p. 407-435.

SILVA, José Afonso. Curso de Direito Constitucional Positivo. $32^{\mathrm{a}}$ ed. São Paulo: Malheiros Editores, 2009.

SOUTO, Marcos Juruena Villela. Estímulos Positivos. In: JUSTINO DE OLIVEIRA, Gustavo (Coord.). Terceiro Setor, Empresas e Estado. Belo Horizonte: Editora Fórum, 2007, p. 15-38.

SOUZA, Leandro Marins de. Parcerias entre a Administração Pública e o Terceiro Setor: sistematização e regulação. 2010. 288f. Tese (Doutorado em Direito do Estado) Faculdade de Direito, Universidade de São Paulo. São Paulo, 2010.

STORTO, Paula Raccanello. A Incidência do Direito Público sobre as Organizações da Sociedade Civil sem Fins Lucrativos. In: DI PIETRO, Maria Sylvia Zanella. Direito Privado Administrativo. São Paulo: Editora Atlas, 2013, p. 362-375.

SUNDFELD, Carlos Ari (Coord.). Parcerias Público-Privadas. 2. ed. São Paulo: Malheiros, 2011. 
SUNDFELD, Carlos Ari. Fundamentos de Direito Público. São Paulo: Editora Malheiros, 1992.

. Guia Jurídico das Parcerias Público Privadas. In: SUNDFELD, Carlos Ari. In: Parcerias Público Privadas. 2. Ed. São Paulo: Editora Malheiros, 2011, pp. 17-46.

SUNDFELD, Carlos Ari; SOUZA, Rodrigo Pagani de. As Modernas Parcerias Públicas com o Terceiro Setor. In: Contratações Públicas e seu Controle. São Paulo: Editora Malheiros, 2013, pp. 42-78.

TORRES, Silvia Faber. O princípio da Subsidiariedade no Direito Público Contemporâneo. Rio de Janeiro: Editora Renovar, 2001.

TOURINHO, Rita. Terceiro Setor no Ordenamento Jurídico Brasileiro: Constatações e Expectativas. In: MODESTO, Paulo (Coord.). Nova Organização Administrativa Brasileira. $2^{a}$ Ed. rev. e ampl. Belo Horizonte: Editora Fórum, 2010, p. 321-340.

VIOLIN, Tarso Cabral. Terceiro Setor e as Parcerias com a Administração Pública: Uma Análise Crítica. 2a ed., rev. e ampl. Belo Horizonte: Editora Fórum, 2010.

ZEN, Marcela Roza Leonardo. Licitação e Terceiro Setor: Reflexões sobre o Concurso de Projetos da Lei das OSCIPs. In: OLIVEIRA, Gustavo Justino de (Coord.) Direito do Terceiro Setor. Belo Horizonte: Editora Fórum, 2008, p. 75-98.

ZOCHUN, Carolina Zancaner. Da Intervenção do Estado no Domínio Social. $1^{\text {a }}$ ed. São Paulo: Editora Malheiros, 2009. 